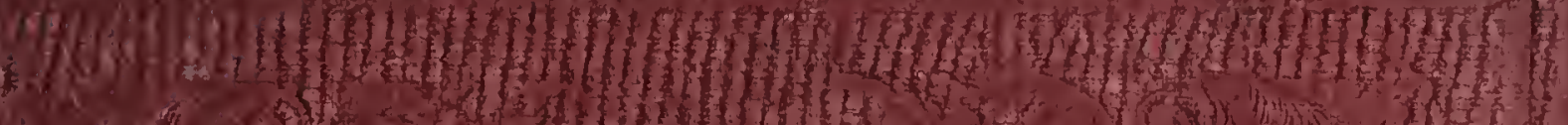

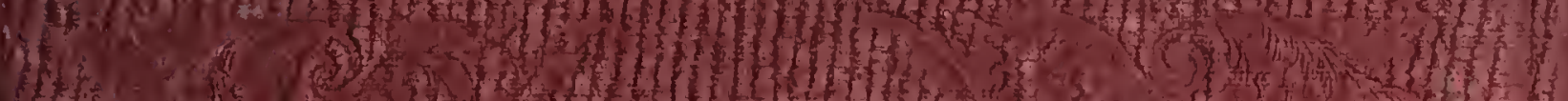
1.4

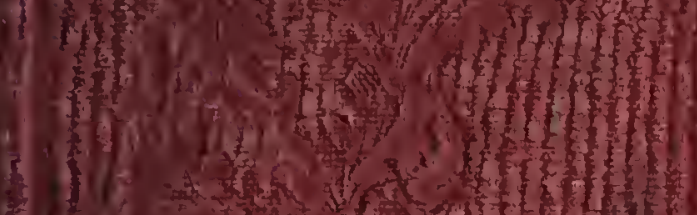
(2)

Whet

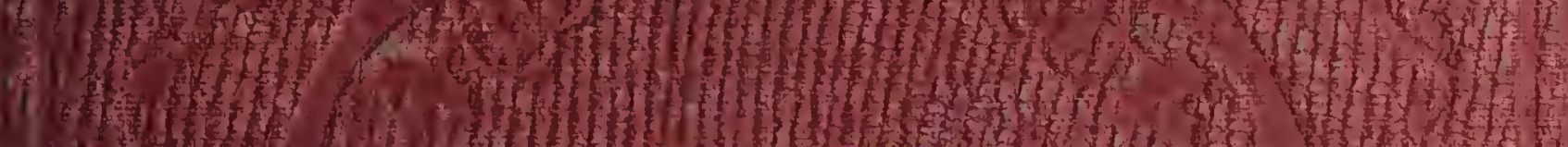

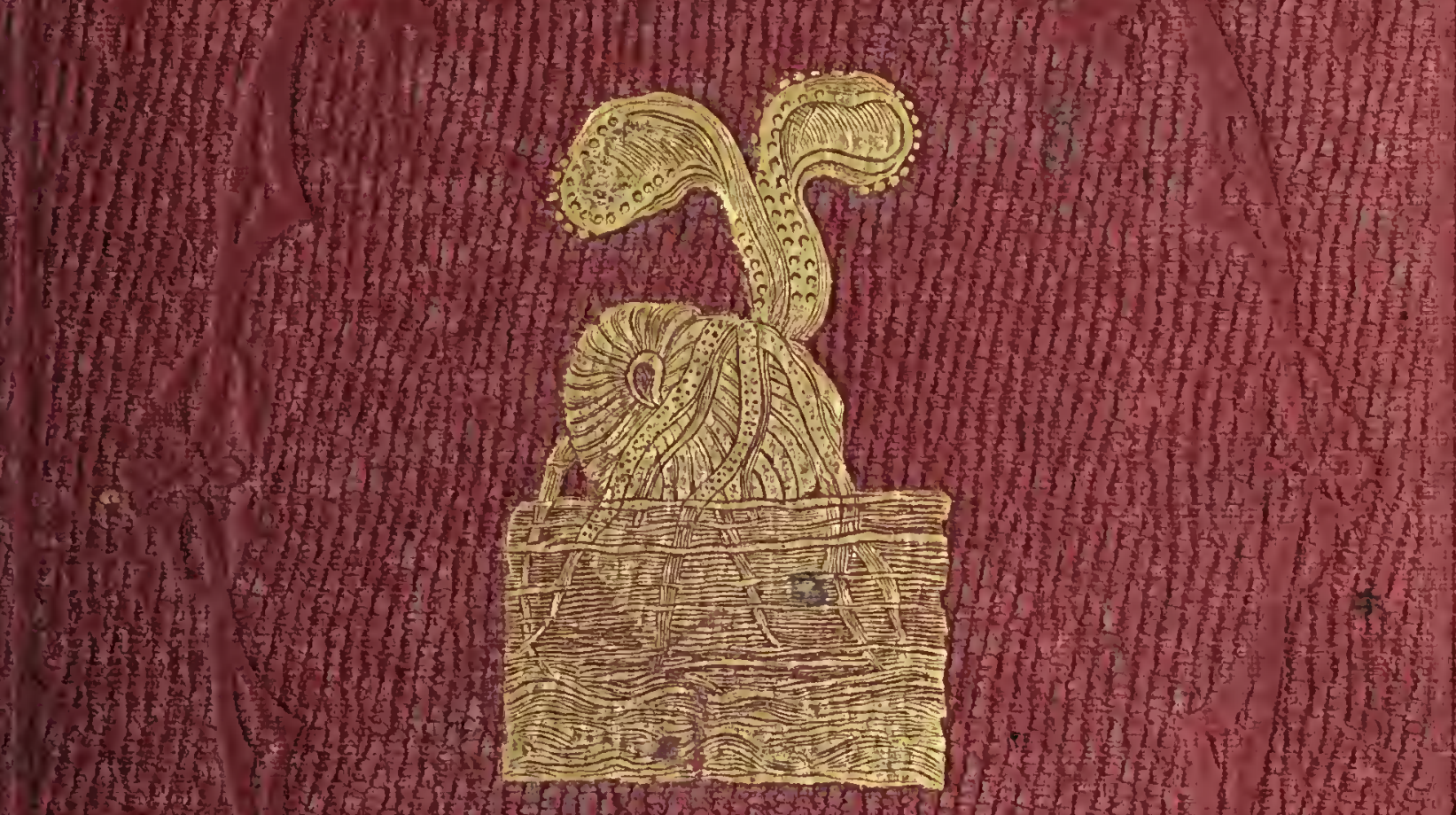

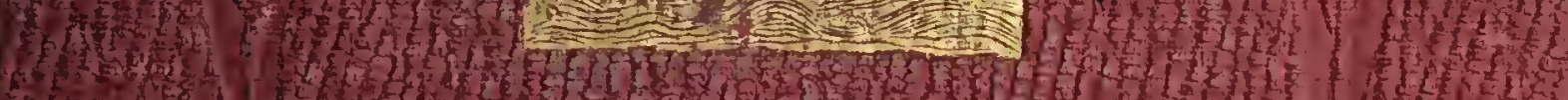
13
3

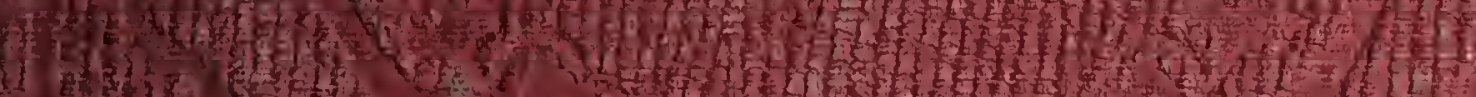

7.

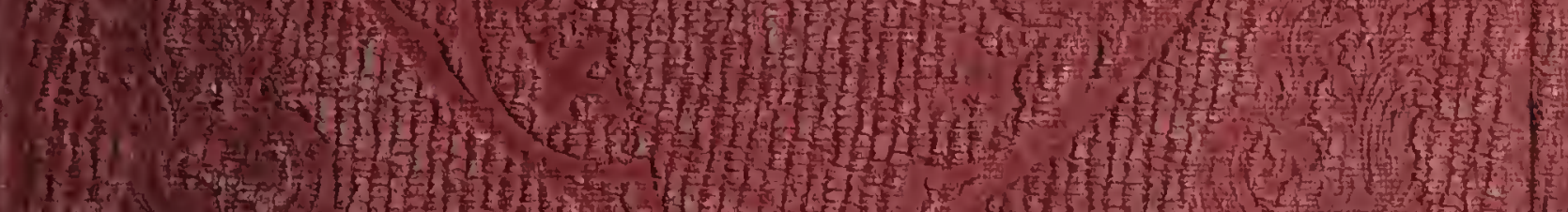

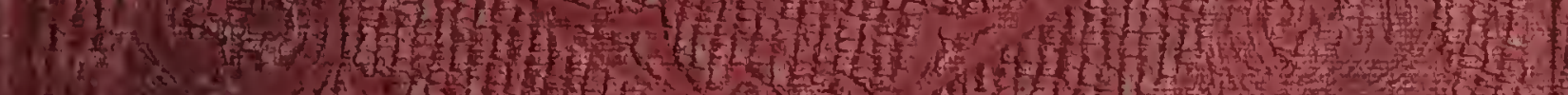

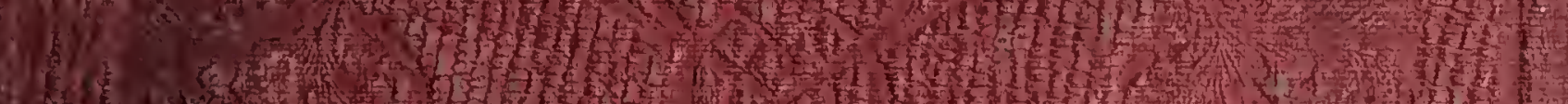

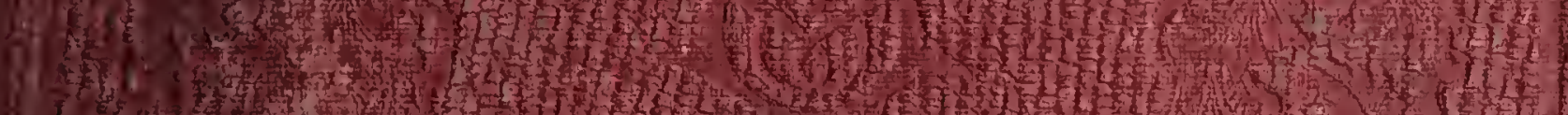

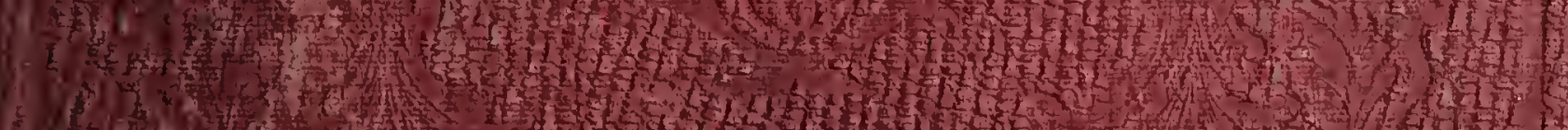

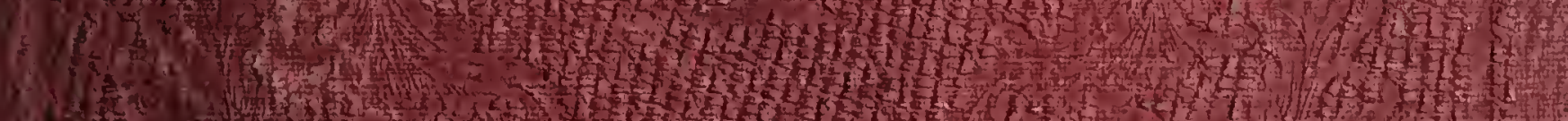
1)

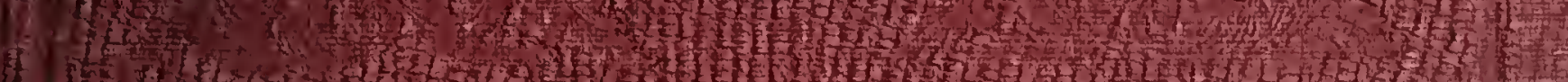

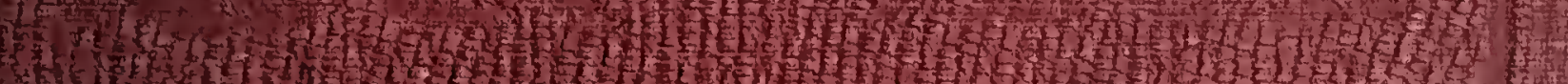

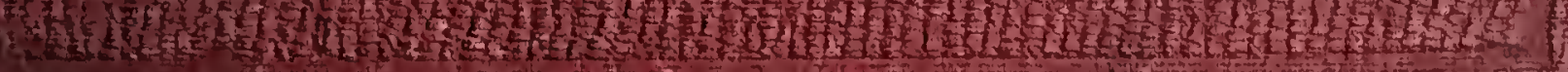


Tom From a.k.2.

Library

of the University of Toronto 
Digitized by the Internet Archive in 2018 with funding from University of Toronto 


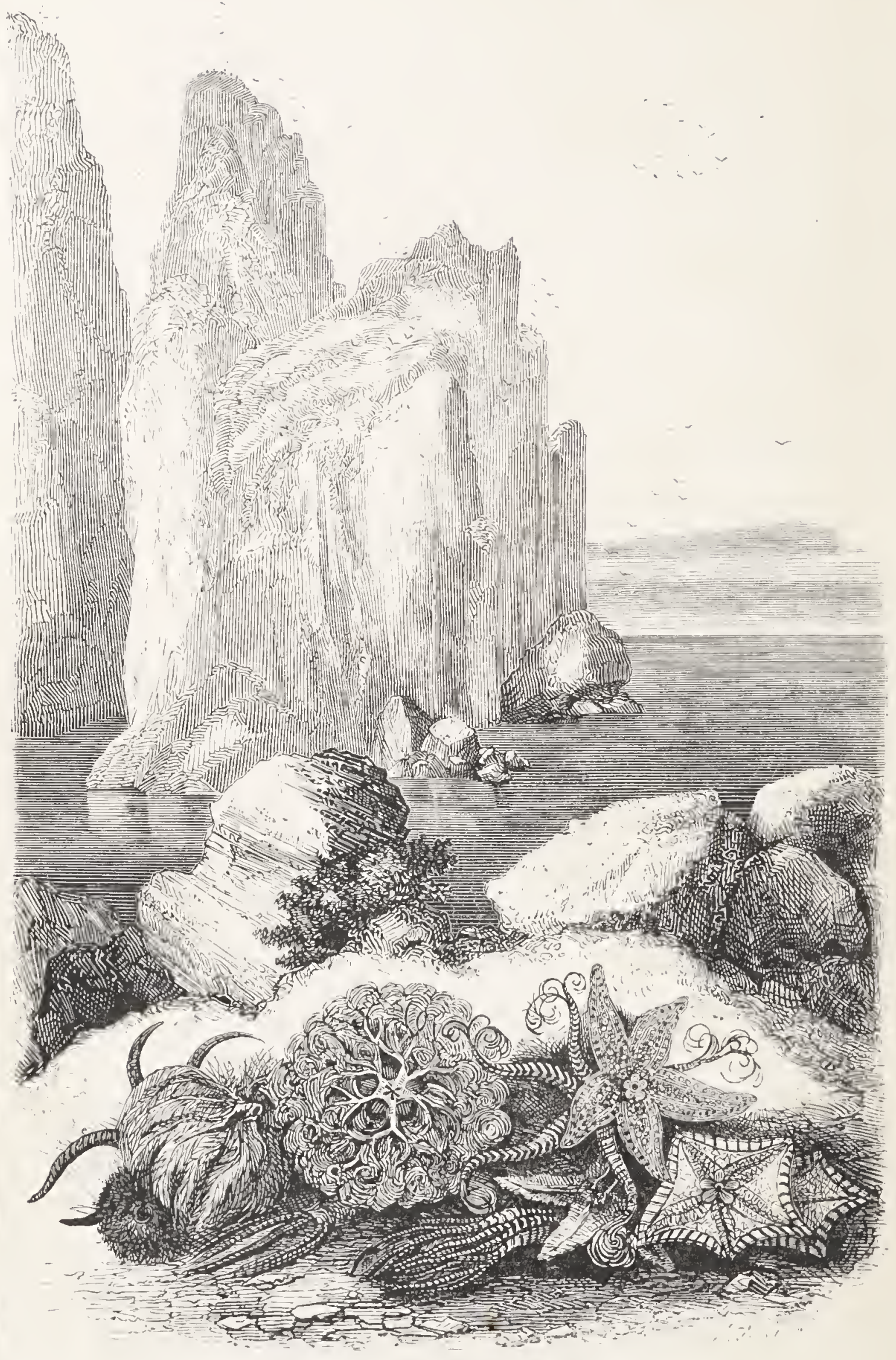




\title{
LIFE IN THE SEA;
}

Or

\section{THE NATURE AND HABITS OF MARINE ANIMALS.}

WRITTEN AND COMPILED BY

\section{A S CELLE W RA X A L L.}

\begin{abstract}
"Now is it pleasant on the summer eve, When a broad shore retiring waters learc, Awhile to wait upon the firm fair sand, Where all is calm at sea, all still at land; And then the ocean's produce to explore, As floating by, or rolling on the shore."
\end{abstract} Crabbe.

\section{LONDON:}

HOULSTON \& WRIGHT, 65, PATERNOSTER ROW. 
LONDON:

PRINTED BY J. WERTHEIMER AND CO., CIRCUS-PLACE, FINSBURY-CIRCUS. 


\section{PRE FACE.}

WITHIN the last few years our Marine Literature has obtained a very satisfactory development. The labours of Gosse, Harvey, and Lewes, have not been bestowed in vain; and the English have displayed a most refreshing desire to acquaint themselves with the wonders of the deep.

It struck me, however, that although so many choice works have been presented to the study of our amateur naturalists, there was no single work which described fully "Life in the Sea," no popular handbook which told the student all the marvels which the natural history of the submarine kingdom offered for his inspection. This want, then, I have attempted to supply.

I have avoided all scientific details, partly through a desire to render my book amusing, and partly because the variety of topics discussed in it occupied all my pages. My great object has been to indicate the most 
interesting circumstances connected with the Ocean family, and thcir relation to man. Hence it is natural that greater space should be devoted to the Cetacean and Seal familics than to Annclids and Jelly-fish: that, among the fishes, the little Herring is more particularly described than the mighty Shark; and the modest Oyster receives morc attention than the giant Bivalves of the Indian Ocean.

This work is principally based on a German compilation by Dr. Hartwig, bearing the title of "Das Leben des Mecres." I, therefore, claim the sole merit of having carefully collated authorities, and done my best to render the book correct in all particulars.

It would be ungrateful to omit mentioning the valuable aid rendered me by $\mathrm{Mr}$. W. Francis Ainsworth, F.R.G.S., who has carefully revised the proof sheets, and corrccted various ovcrsights. With such assistance I can confidently recommend the volume to my readers, as being alike interesting and instructive, as well as correct.

Lascelles Wrayai.l.

Kensington, June, 1860. 


\section{TABLE OF CONTENTS.}

CHAPTER I.

General Remarks on Cetacea-The Greenland Whale-Its Food and EnemiesThe Whale stranded at Ostend-The Southern Whale-The Spermaeeti Whale-The Narwhal-The Dolphin-Fiction and Fact-The PorpoiseHistory and Description of the Whale Fishery-Fishing at the Ferroe Islands.

\section{CHAPTER II.}

Manatus and Dugongs-The Rhytina-Seals and Eskimos-Menelaus in the Sealslin-Barbarous Destruction of the Seals in Behring's Sea and the Southern Ocean-Remarkable History of a Sealer from Geneva-The Common SealThe Ursine Seal-Its Paternal Affection-The Shaggy and Smooth Sea Lion -The Elephant Seal-The Arctic Walrus-Beechey's Description of a School of Walrusses-The Polar Bear-Affecting instance of its Love for its Cubs--The Sea Otter-The Common Otter. . . . . . . .

\section{CHAPTER III.}

Astounding number of Aquatie Birds-Shore Birds-Cunning of the Plover to entice the Foe from its Nest-Migrations of the Strand Birds-Aquatic Birds generally-Anatidæ--The Eider Duck-The Long-tailed Duck-The Grey Duck of the Falkland Islands-The Rock Goosc-Auks and Penguins-The Cormorant-Fishing in China-The Frigate Bird-The Gulls-Stormbirds -The Albatross-Birdcatching at St. Kilda-The Guano of the Chincha Islands. . 


\section{CHAPTER IV.}

The Extinct Sanrians-Structure of Tortoises-Their Shape-Mode of laying Eggs-Melancholy Fate of the Young-Turtle-eatehing in Ascension Island -Their Use among the Romans as a Reeipe-Torioise-shell-The Great Sea Serpent.

\section{CHAPTER V.}

General Remarlis on Fish-Organs of Mrotion : Tail, Fins, Natatory BladderSeales-Beauty of Tropieal Fish-The Gills-The Journeys of eertain Fish on Land-Weapons of Fishes-The Sea Wolf-The White Shark-The Saw Fish-The Sword Fish-The Torpedo-The Star-gazer-The AnglerRemarkable Capture of Flies-The Chætodon Rostratus-The Remora employed to eatch Fish-Strange Weapons of Defence of some Fish-The Trachinus-The Stickle-back-The Doree-The Flying Fish-Numerous Enemies of the Fish-How many Fish may there be?-The IIerringImportance and History of the Herring Fishery-The Pilchard-The Sprat -The Cod-fisl--The Sturgeon-The Sterlet-The Salmon-The TunnyLouis XIII. and the Madrague-The Mackarel-The Bonita-The Muræna -The Lamprey-Flat-fish, or Pleuronctæ-The Halibut-The TurbotThe Sole-The Plaice-The Skate-Enormous Inerease of Fish-Their Diseases-Modes of telling their Age. . . . . . . .

\section{CHAPTER VI.}

How do the Crustaeeans differ from Inseets and Spiders?-Organs of Respiration in the Crustaeeans-'The Crab-'Tenacity of Life-The Horseman-Cancer Pagurus-The Japanese Giant Crab-The Pinnotheres-The Hermit CrabThe Prawn-The Lobster-The Process of easting its Shell-Voluntary casting off Limbs-Extraordinary Metamorphosis of the Crab.

\section{CHAPTER VII.}

General Remarks on Annelids-The Eunice Sauguinca.-Beauty of the Marine Annelids-The Great Tapeworm-Food and Enemies of the Annelids-The Tube-inhabiting Annelids. . . . . . . . . . . 
Molluses generally-The Nudibranchs-The Cephalopods-Their StructurcStrange Peculiarities of their Skin-D'Orbigny's resisting ApparatusImmense number of Cephalopods-Their Voracity-Their Enemies-Their Value to Man-Marvellous Size of some Cephalopods-The Kraken-The Argonaut-The Nautilus-Great Rarity of the Animal-The Cephalopods of the Primæval Ocean.

Gasteropods-Their Organs of Respiration-Their Bcauty-Their Movements-Their Metamorphoses - The Sea Hare-The Carinariæ-The Patellæ - The Haliotids-The Spiral Conchilia-Their Variety and Beauty-High Prices paid for some Varietics-Movement of the Gasteropods-The Ianthines -Abode of the Marine Snails-On what do they feed?-Their EnemiesTheir Value to Man.

Pteropods-Their Struct ure and Mode of Life.

Acephala or Lamelli-branchiates-General Remarks on their StructurePholades-Food of the Aceplala-Their Numerous Enemies-The MussclIts Artificial Breeding-The Oyster-Oyster Beds made by the RomansOyster Breeding in the Lago di Fusaro-Pearl Fishery in Ceylon-How are Pearls formed?-The Spondylus Regius-The Giant Mussel.

Brachiopods-The Salpæ-Their extraordinary Altercations of Gencrations -Chamisso.

\section{CHAPTER IX.}

Asteroids : their Suckers; the Lymphatic System-Voracity of the Asteroids ; their power of Reproduction ; their Metamorphoses-The Comatulæ-Brittle Stars-Urasters-Sun Stars-Sea Urchins-The Pedicellariæ-House and Mouth of the Sea Urchins-Holothuriæ; their remarkable Faculty of Dismembering themselves-Catching Trepangs off the Northern Coast of Australia.

\section{CHAPTER X.}

Structure of the Jelly Fish-The Disc, or Pulmonigrade Jelly Fish: how do they move?-Rhyzostoms-Medusæ-Ribbed, or Ciliograde Jelly Fish-The Cydippe Infundibulum-The Physograde or Tubular Jelly Fish-Socialistic Ocean Republics-The Velcllæ-The Caravel, or Portuguese Man of WarStory of a Peruvian Sailor. . . . . . . . . 
Polypes-Sea Anemones-Lithophytes, or Stolle Corals-Coral Reefs, Barren Reefs, Encircling Reefs, Shore Reefs, Fringing Reefs; Atolls, Lagoon Islands : their formation, according to Darwin-How do Coral Reefs become the abode of Man?-Coral Fishing in the Mediterranean. . . .

\section{CHAPTER XIY.}

The Minutest Life-Foraminifera-Amæba: their wondrously simple Construction-Diatomacer-Infusoria: their importance in the Oceanic Household.

\section{CHAPTER XII.}

Marine Plants-Zostera Marina-Ulvæ and Enteromorphæ-Varieties of Fucus Kelp, Varech-Laminariæ-Nacrocystis Pyrifera-The Submarine Forests at Tierra del Fuego-Nereo-cystis Lutkiana-The Sargasso Sea-Irish MossJin-Jan, or Agar-Agar-Sponges : their remartiable Growth.

\section{CHAPTER XIV.}

General Remarks on the Geograplical Distribution of the Animal and Vegetable Kingdoms. -Dependence of all ereated Beings on Space and Time-Influences which determine the Distribution of Marine Creatures-The eight rertical Regions of Organic Life in the Egean-The Inhabitants of the

- Red Sea.

\section{CHAPTER XV.}

Phosphorescence of the Sea-Cause of the Phenomenon.-Mammaria Scintillans -Glistcning Ancmones and Beroës - Intense Light of the Pyrosoma Atlantiea -Phosphorescent Marine Plants-Passages from Byron, Coleridge, and Crabbe, relating to the Phosphorescence of the Sea. 


\section{LIFE IN THE SEA.}

\section{CHAP'TER I.}

General Remaris on Cetacea - The Greenland Wiale - Its Food and Enemies. - The Whale stranded at Ostend. - The Southern Whale.-The Sperma ceti Whale.-The Narwhal. -The Dolphin.-Fiction and Fact.-The Porpoise.-History and Description of the Whale Fishery. - Fishing at tile Ferroe Islands.

$W^{\mathrm{E}}$ commence our description of the denizens of the sea, with the gigantic Cetacea, or Aquatic Mammalia, and propose to descend the ladder of oceanic creation, step by step, to the smallest and simplest types of existence. We regret that we shall have to pass by many of them in silence, or only devote a few lines to them; as in such an enormous field, where thousands on thousands of new and rare forms present themselves, only those which stand out prominently attract the attention of the casual observer. But if we can succeed in drawing our readers' notice to some marvels of the world of waters, hitherto unknown to them, or slightly lift the veil which conceals the mysteries of the deep, our object will be attained; and we trust that we shall have performed a meritorious task.

Of all the creatures that populate the mighty ocean, the 
Cetacea are the most perfect. Through their internal construction, they approximate in many respects to human beings, and their behaviour displays traces of a higher feeling; for the mother loves her cub, defends it in the hour of danger, and is apt to forget her own peril in her passionate attempts to protect it. Like ourselves, they respire through lungs, and possess a double (venous and arterial) heart, through which, streams of warm red blood constantly flow. The anatomical structure of the pectoral fins bears a remarkable resemblance to the human arm, as its skeleton is equally composed of a shoulder-blade, arm, a two-boned fore-arm, and five parted fingers. But the upper extremity, which, in us, moves freely, is, in the Cetacea, firmly attached to the body down to the wrist; and the fingered hand, which performs such wondrous deeds under the guidance of the human will, is, in the case of the whale, covered with a thick skin, and becomes a broad, undivided fin. Yet it is designed for some higher function than mere steering, for with its assistance the mother guides and protects her cub. The pelvis is only found in a rudimentary form, and the lower extremities fail entirely. Their place is supplied by the powerful horizontal tail, by means of which the animal moves so rapidly through the water.

The Cetacea are also distinguished from fishes by being viviparous, by a much larger quantity of blood, by a smooth skin (not covered with scales, as in the former), beneath which is a thick layer of fat; but, above all, by having a single or double breathing-hole or blower on the upper portion of the head, which, though resembling the nostrils of other animals, is not employed for smell, but solely for respiration. 
The natural history of the Cetacea is still very defective; and we need not feel surprised at it, when we reflect that these animals are generally met with in the most inaccessible seas, where the scientific inquirer can rarely approach them; while the rapidity of their movements only permits a transient glance at their external form. Since but little is known of their habits and mode of life, and while many a species is still utterly unknown, it may often happen that the same variety is described under different names, thus causing great confusion.

It would be beyond our scope and limits to point out such errors, or write a more detailed monogram on the Cetacea: we will, therefore, content ourselves with enumerating the most interesting facts known about the predominant varieties of the family.

The Cetacea are subdivided into the "toothless" and the " toothed." The former, or baleen whales, have two blowers on the head, running longitudinally; but in the toothed Cetacea (Spermaceti, Narwhal, Dolphin), the orifice is single, and across the head. As they do not breathe, they have no voice; though the puffing of the larger whales sounds, at the distance of a mile, like the murmur of the wind through an organ-pipe.

The baleen whales are again subdivided into the smoothbacks (Balcena), and the Rorquals (Balcenoptera), which have a dorsal fin on the lower part of the back. To the former belongs the Greenland whale (B. Mysticetus), the largest of living animals, and most valuable to man of all the Cetacea. Its extreme length, according to Scoresby, is sixty to seventy feet; and at the thickest part of the body, 
behind the pectoral fins, it has a circumference of thirty to forty feet. As it is very nearly of the same specific gravity as water, its weight can be determined with sufficient accuracy. Scoresby estimates the weight of a whale that measured sixty feet at a hundred tons.

Other naturalists give it still larger dimensions; and it is possible that, in former times, ere man pursued whales with such pertinacity, they may have attained a length of one hundred feet, with a corresponding circumference. But whales of three hundred feet in length, such as Tilesins describes, must have been seen through the magnifying-glass of a luxurious fancy, and belong to the same race as Pliny's three hundred feet saw-fish, which, as he tells us (Hist. Nat., lib.ix. 2), inhabit the Indian waters. This clumsy animal's organism is in every respect disproportionate. While the tail, which is twenty-four feet wide, covers a space of from eighty to a hundred square feet, the pectoral fins are only about six feet in length. The monstrous head takes up onethird of the body, and is provided with such an enormous mouth, that, when open, it forms a cavity as large as a ship's hold. The monsters of terra firma - the elephant, rhinoceros, hippopotamus - are gifted with claws and teeth corresponding with their size, which can uproot trees, and crush the scale-plated crocodile: but it is very different with the giant of the ocean, whose masticating instruments are scarcely able to

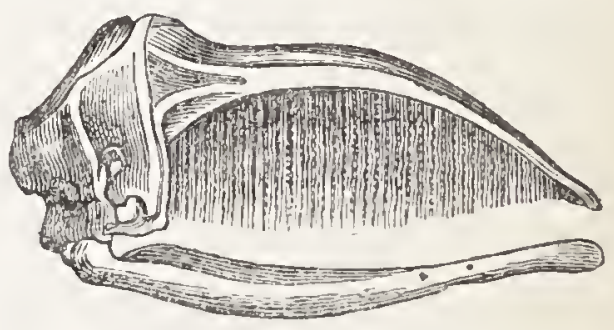
chew a paltry herring. In its tremendous throat, some five 
hundred triangular horny plates, hanging from the palate, and arranged in the manner of a comb, supply the place of teeth. The largest laminæ, which hang on the sides of the mouth, attain a length of fifteen feet, and a width of twelve to fifteen inches: before and behind they are much shorter. On the palate there are also false layers, of a quadrangular shape, about the thickness of a quill, and about four inches in length. Thus the mouth of the whale resembles a hide covered with thick hair, beneath which lies the monstrous tongue, ten feet broad, and nineteén long.

This peculiar arrangement of the mouth suits the requirements of the whale admirably, as its food does not consist, as might be assumed, of the larger sea denizens, but of the small creatures (Medusæ, Crustaceans, Clio Borealis, and other soft animals) with which the northern seas, especially between the parallels of $74^{\circ}$ and $80^{\circ}$, are crowded. In order to obtain its food, the whale swims rapidly, with open jaws, along the surface of the water. When it shuts its mouth, and expels the swallowed stream through the whalebone fringe, thousands of these small animals are caught in the forest of fibres as in a net, and are rubbed off and swallowed by the aid of the tongue. What a quantity of these creatures is needed to support a colossus weighing a hundred tons! The back of the whale is of a handsome black, with white stripes; the belly and lower jaw are bright white. The skin is about an inch thick, and covers a layer of fat of fifteen inches in thickness, which, though a famous protection to the animal from cold, attracts the death-dealing harpoon.

The Whale usually proceeds at the rate of four miles an hour, but its speed is marvellously increased when terror or 
pain drives it through the waves. At times it rises to the surface with such violence, that it leaps quite out of the water, as if in sport. When it falls back, the shock creates a miniature storm, which can be felt for some distance; or at times it lifts its enormous head perpendicularly out of the water, so that the deceived sailor fancies it is but a rock after all. Suddenly the supposed rock heaves over, and the enormous fin begins lashing the water with such fury, that the sound rolls over the solitudes of the Arctic Ocean like the thunder of cannon. The utter want of pluck the whale shews is in great contradiction to its strength; for even a bird, if it sit on the whale's back, causes the latter great restlessness and terror. Besides men, whose pursuit we will presently describe, a number of enemies - great and small - constantly follow the whale, and embitter its life. The Swordfish (Typhias gladius) and the Thresher (Carcharias vulpes) often attack it in alliance. So soon as its back appears above the water, the threshers spring several yards into the air, and, in falling, give the whale the most tremendous blows with their long tails. At the same time, the sword-fish are boring and wounding it beneath; and thus, after an engagement of several hours, the poor bleeding, persecuted animal, yields to the attacks of its raging foes. The Greenland shark, again (Squalus borealis), is one of the whale's most bitter enemies, and tears pieces out of its body as large as a man's head.

This Shark, according to Captain W. Scoresby's report, is so greedy and insensible to pain, that even after it has been stabbed by the flencers who are cutting up a dead whale, it will return in a short time, and continue its interrupted 
meal. At the same time, it is so tenacious of life, that its heart, when cut out, beats for several lours after death, and the body, if cut up, displays similar signs of life. Hence it is very difficult to kill; and it is even said to be dangerous to place your hand in the mouth of a head recently cut from the body. Strangely enough, it never attacks human beings; for though the flencers frequently fall into the water at a time when the sharks collect by hundreds, Scoresby cannot mention a single instance in which any one was ever bitten or wounded. The polar bear also pursues the whale, when it finds a chance, in the gulfs of the Arctic Sea; but the enmity of the Narwhal is erroneous, for they have often been seen living together on amicable terms.

In addition to these dangerous attacks, the giant of the ocean is exposed to the torments of many tiny animals, which seem to take revenge for the wholesale slaughter of their brethren. The whale-louse burrows into its back, and devours it so greedily, that you fancy some beast of prey has torn off large lumps. In summer, when the plague is at its height, swarms of gulls may be seen accompanying the whale; and so socn as it rises to the surface, they settle upon it, to devour these disgusting parasites. By this they doubtlessly do the wliale a great service, though the pecking of their beaks in the wounded skin may not produce an agreeable feeling. Barnacles, too, cover the whale in sucl quantities, that its black back appears to be spotted white; and at times its mighty head is overgrown with sea-weeds, which have taken root in this moving soil, and remind the spectator of Birnam Wood.

The habitat of the Greenland whale, as its name indicates, is in the Arctic seas of North America, Davis' Strait, Baffin's 
and Hudson's Bays, and it is also found in large numbers along some parts of the northern coasts of Asia and America. It never finds its way into the Baltic, and is rarely seen within two hundred miles of the British coast.

The Rorqual (Rorqualus borealis), although longer than the Greenland whale, is far inferior to it in bulk, for it has a tapering head. The whalebone it produces is smaller and stronger than that of its smooth-backed congener, and hence it is not so good for the purpose of catching food. But this variety of whale feeds on herrings and mackerel, whose shoals it follows. Like the Greenland whale, it is black on top, and white below; but is distinguished from it by numerous deep furrows of a blood-red hue, which rum beneath the throat and breast to the middle of the belly. It also inhabits high northern latitudes, and is frequently seen on the skirts of the ice-fields between Bear Island and Jan Mayen; but at times it visits lower latitudes, and is often stranded on the Baltic coast.

Confining our attention exclusively to Ostend, we find, not only in the olden chronicles, but in present history, more than one instance preserved. Thus, in November, 1402, a storm cast eight rorquals ashore close to the port. The largest was seventy feet in length; and they yielded, on an average, twenty-four casks of oil.

On the 20th January, 1762, a Rorqual, fifty feet long and forty round, was found on the coast between Blankenbergh and Ostend. It was sold by auction for 192 florins, which went to the crown.

The most celebrated Rorqual, however, known to history, except the one which swallowed Jonah, was found by a fish- 
ing boat, floating dead in the Baltic, on November 3, 1827, and the next day towed to the mouth of Ostend harbour. Here, however, the ropes broke, and the giant corpse drifted ashore, about a hundred yards from the port. There was an enormous rush to see this distinguished visitor. From all parts of the country crowds came in; and, of a surety, Gulliver did not create a greater sensation in Lilliput, than this enormous eighty-four-footer did through Flanders and Brabant. Generally, such valuable "finds" are lost to science through the ignorance of the fishermen; but fortunately there were two men present who knew how to obtain advantage from it, though in different ways: one, a speculator, who, seeing an opportunity to make money, bought the whale on the spot for 3000 florins; the other, Dr. Paret, who undertook the difficult task of separating the skeleton from the festering mass, and putting it together in a right order.

As it was feared the next spring-tides might carry off the body, sixty-two workmen were employed day and night in flencing it. The valuable fat was collected in barrels, the meat and entrails buried in the sand, and by the 19th November, the bones were perfectly freed. On this occasion, the purchaser instituted a remarkable festivity: sixteen persons danced a quadrille in the lower-jaw, and a hundred and thirty-four men drank, at the same time, the king's health. It may be supposed that it was no trifle to carry the tail fins, nineteen feet long and nine broad, which had been preserved in spirits of wine, into the town: special vehicles had to be built to remove the gigantic cases. At length, all was brought together in the Hotel de Commerce; and Paret, assisted by ten intelligent workmen, began binding the skeleton together 
artistically, so that it might be easily taken to pieces and put together again. No anatomist had ever had such a gigantic experiment, and Paret gained the applause of all men of science by the manner in which he solved the problem.

In the meanwhile, an elegant transportable pavilion had been got ready, in which the mouster would be shewn to, the astounded world. On the 30th April, 1828, it began its tour, which extended to Petersburg, and thence to America, where the skeleton is still preserved in a museum.

In the antarctic hemisphere, the southern whale ( $B$. arctic $\alpha$ ), by its abundance of oil, supplies the place of the Greenland whale. It keeps along the coasts in the temperate latitudes, and in those positions of the adjoining seas where the varying colour of the water shows that immense quantities of Medusæ and Molluscs are present. It is never seen, however, in the central parts of the Pacific. In spring it seeks the bays on the steep west coast of South America, where quiet water supplies it with abundance of food, and gives birth to its cub. At this period, which is cailed the " bay season," the whalers cast anchor in the Gulfs of Chiloe, Talcahuano, Conception, St. Vincent, etc., and often reap a rich harvest. At the southern extremity of Africa, as well as on the coasts of Brazil, Australia, New Zealand, Kerguelen's-land, etc., this variety of whale is also frequently found. In the higher southern latitudes the hump-back, and nearer to the pole the razor-back, are visible, but they are not nearly so valuable to the whaler. When Dumont d'Orville, after the southern expedition in which he discovered Terre Louis Philippe, put in to Talcahuano, in May, 1838, and told the whalers of the enormous quantities of Cetacea he had seen in the high Polar 
Seas, their eyes sparkled with delight; but when he added, they were chiefly hump-backs and razor-backs, they were greatly disappointed. The hump-back is lean, and yields but little oil: while the razor-back dives with such rapidity, that it often breaks the cord to which the harpoon is attached, or pulls the boat down after it. Still it is sometimes chased by Americans, in those shallow parts of the sea, where it is forced to return to the surface soon.

While the smoothbacks bleed to death by thousands for the sake of their oil and whalebone, the spermaceti, or cachalot (Physeter macrocephalus), arouses avarice by its peculiar tallowy fat, which does not form' a thick stratum beneath the skin, but is found mainly in the upper portion of the gigantic head. Ambergris, which is rarely met with, is a production of the sperm whale. This odorous waxy substance is found in lumps, weighing several pounds, floating in the sea, or hanging from the rocks. It is sold for a guinea an ounce in London, but is, after all, only an unhealthy secretion.

The sperm attains the size of a moderate whale: one stranded on the coast of Brittany, in 1784, was forty-four feet long, and had a circumference of thirty-four feet at the thickest part. The tail is small in proportion to the size; the layer of fat under the skin is about six feet thick on the back, but thinner on the belly. The colour of the back is slatish grey with white spots; the belly is white. The want of beard, and the presence of sharp teeth in the lower-jaw, prove to us that the food of the cachalot is very different from that of the true whale. It lives principally on cuttlefish and other polypods, which attain an extraordinary size in the southern waters. It also swallows smail fish, but does not go out of its way to catch them. 
The central bottomless deserts of the ocean, or the vicinity of the most precipitous rocks, are its usual habitat, and it is rarely found in shallow water. Its geographical extension occupies an extraordinary space; for, with the exception of the Polar Seas, it leaves no portion of the ocean entirely unvisited. From the southern hemisphere, which is its principal abode, it wanders up to the northern Polar Seas. The sperm whale is gregarious, and generally swims in company with a band of brothers. Large parties of forty or fifty are called by the whalers "schools," smaller ones, "pods." If a Sperm be seen alone, it is generally an elderly or philosophic animal, which has either been expelled from society because of its moroseness, or else in the evening of its life it devotes itself to solitude. The sperm whale does not throw a jet of water into the air through its blower, but only a dense column of steam, which rises several yards, like smoke from a chimney. At least, excellent authorities maintain this; among others, the circumnavigator Liitke, and Scoresby, who killed four hundred and ninety-eight whales in twenty-eight voyages. The noise made by the Sperm whale in blowing off the steam is so great, that the practised whaler can detect its presence in the neighbourhood by the ear. The sperm whale is very rarely found covered with barnacles and sea-weed; this is explained by the fact, that it inhabits deeper water, and moves about with great rapidity, while the other variety stays principally in shallow water, and is slow in its movements.

The Narwhal, or Unicorn-fish, attains a length of twenty to twenty-five feet. It is of a greyish white colour, with numerous white spots, which apparently penetrate the skin; and as its head is in correct proportion to the body (one-seventh of 
the length), it is justly considered one of the handsomest of the Cetacea. It is distinguished from all the other members of the family by its powerful horizontal horn, nearly ten feet long, which grows out of the point of the upper-jaw. This tremendous weapon, whose use no one can exactly explain, for it is absent in the females, formerly produced enormous sums; for it was ascribed to the fabulous unicorn. Even now it is valued on account of the excellent ivory, which is harder, heavier, and less liable to turn yellow than that of the elephant. Hence the whalers are always very glad to harpoon a narwhal; but they only succeed in doing so in the narrowest bays, for it is a first-rate swimmer, and has a watchful eye. In spite of its menacing appearance, the narwhal is a harmless, sucial animal. They are frequently seen sporting together, crossing their horns, or striking them together, as if fencing. 'The opening of the mouth is proportionately so small, that it hardly admits a man's hand. Scoresby found in the belly of a narwhal the arm of a cuttlefish, which appears to be its staple food, as well as pieces of plaice and slate. The narwhal inhabits the Polar Sea, is found in large numbers in Davis' Straits' and near Disco, but never in the Pacific. It very rarely goes further south, though, in 1800, one was captured at Boston, in Lincolnshire, and, in 1736, two were killed on the German coast.

The Dolphins are distinguished from the Sperm-whale by the more correct proportion of the head, from the Narwhal by the absence of the horn. They usually liave sharp teeth in both jaws, all of one shape. The number of varieties, all of which are not yet known, appears to be very considerable. Linné distinguishes four varieties of Sperm, and three of 
Dolphins; but now only one spermaceti whale is allowed to exist, while the dolphin family has increased to more than thirty varieties. They are divided into Càing whales (Dclphinus melas), whose forchead descends almost in a straight line to the end of the snout; Grampuses (Orcini), which are distinguished by a tall dorsal fin; and Porpoises (Phocanx), which, though of smaller size, are provided with a larger number of teeth.

Among the latter, the classic Dolphin of the ancients (Delphinus delphis), which is very prosaically known as the "common," is the most remarkable. It attains a length of nine to ten feet, and, according to Pliny, is the swiftest of all animals, parting the waves more quickly than the bird flies through the air. The sportive schools follow ships for days, and relieve the monotony of a long voyage by their extraordinary vivacity. As if mocking the swiftest sailingvessel, they shoot so far a-head of it, that they disappear from sight, and then return with equal speed to repeat the same joke. Often, too, in their high spirits, they will leap clean out of the water.

Fables have been invented about no animal so much as this. What reader is ignorant of Arion's history, who, when the piratical boatmen forced him to leap overboard, continued his voyage comfortably to 'Tænara on the back of a dolphin, which he had enchanted by his glorious song and lute? Pliny tells an even more extraordinary story of a boy at Baix, who, by frequently feeding a dolphin with bread, rendered it so attached to him, that it carried him daily for several years across the bay to school at Puteoli, and brought him home at nightfall. When the boy died, the dolphin still returned to the accustomed spot, and gradually pined away at the loss of 
its farourite. The also read in the pages of the same classic author, that the dolphins of the coast of Narbonne helped the fishermen in capturing mullet, and were rewarded for their services not merely with a portion of the haul, but with bread dipped in wine. Once, when a king of Caria chained up a captured dolphin in the harbour, a large number of these animals made their appearance, apparently imploring, with manifest signs of grief, the release of their comrade, until the king granted their prayer. We also find in Pling, that the jounger dolphins are always accompanied by their elders or guardians. Dolphins hare been seen remoring a dead one, for fear of it being lacerated by other fish.

Our incredulous age shakes its head at these and other equally wondrous stories of the wisdom of the dolphin, the truth of which was not doubted by the greatest naturalists of antiquity. They are as little true as the portrait which artists usually draw of the dolphin resembles reality. It has no more sense than the other Cetacea; its feeling for music is so slightly dereloped, that it could not distinguish " Kemo kimo" from one of Beethoren's symphonies; and if it accompanies ressels, it is not through any desire for human society, but for the sake of the pieces of meat that are thrown orerboard.

The Porpoise (Phocona communis) is often confounded with the Dolphin: it is generally from fire to six feet long, and seems the smallest of aquatic mammals. It is found through the whole of the North Atlantic, and in the Mediterranean and Black Seas. While the Dolphin generally prefers blue water, and is more rarely seen on the coasts, the Porpoise likes quiet bays, and a shore protected by rocks; and it often swims a long distance up rivers, so that it has been seen at Paris and Dessau. 
The Porpoise is also an excellent swimmer, and its speed is estimated by Lesson (Voyage de la Vénus) at six leagues an hour. It chases the smaller fish, which rarely escape its sharp teeth. When it rises to the surface to breathe, it only

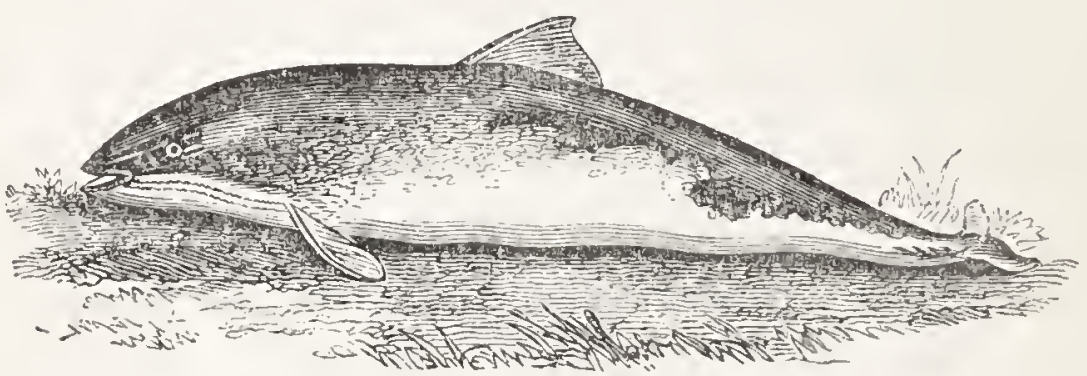

THE PORPOISE.

raises its back out of the water to the blowing-hole, but the head and tail remain hidden. The peculiar undulating movement of the porpoise, and its curious bounds, are the pleasantest sights on board a ship.

The Grampus, or Sword-whale (Phoccena grampus, D. orca of Lacepéde), attains a length of twenty-five feet, and a circumference of twenty-four. One twenty-four feet long was caught off Sheerness in 1759. The upper part of the back is black, the belly white. The dorsal fin is of a conical form. According to Tilesius, they swim at great speed, side by side, in columns of five, like a squadron of Hussars, with head and tail bent downwards, and raise their back, with its black sabre, from the water simultaneously. This is the most notorious of the Dolphin family for its piratical way of living. Its usual food consists of seals and a variety of flat-fish; but it also hunts the porpoise, and the whale would probably regard it as its most dangerous enemy, were there no men. We find in Pliny a masterly description of the combat between these aquatic monsters. At the season when the whale visits the bays for the purpose of giving birth, it is attacked by the grampus, which lacerates 
it with its fearful teeth, and runs with the strength of a a battering-ram against its sides. The startled whale can only save itself from this furious attack by trying to put an entire ocean between itself and its foe. But the latter, active and watchful, drives it further and further inland, till it is stranded or driven on the rocks, and never quits it till the victory is entirely gained. During such a contest, the sea appears enraged with itself; for even if no wind is blowing, waves, such as a storm hardly produces, rise beneath the blows of the snorting monsters.

When the Emperor Claudius was engaged in making the port of Ostium, a grampus was stranded there. The back projected above the surface of the water, and resembled an overturned boat. The emperor ordered large nets to be drawn across the mouth of the harbour, to cut off the animal's retreat, and then attacked it at the head of his Prætorians. The soldiers who surrounded the monster, and threw javelins at it, afforded the Roman people a most amusing spectacle. One of the boats was upset and sunk by the violent lashing of the furious animal.

It is one of the most brilliant triumphs of man's courage and skill, that he dares to seek the hugest monster of the deep behind floating icebergs and amid the impenetrable fogs of the Polar seas, and nearly always succeeds in conquering it.

The breast of the first sailor, Horace says, was girt with triple brass; of what stuff must the hunter have been formed, who with a firm hand hurled the first harpoon at the gigantic whale?

History has not preserved his name, as is the case with 
many another hero: he fared like those brave men who lived before Agamemnon, and descended to Orcus without leaving a trace, because no Homer as yet lived to immortalize their deeds. But history indicates the Basques, as the first civilized race that equipped vessels for a whaling expedition; although, long before them, Icelanders and Normans, as well as many wild races of the north - Eskimos, Kuriles, and Aleutians may have pursued the giants of ocean, though, perhaps, not so scientifically.

At first, the Basques contented themselves with seeking in the adjoining seas the whales (probably Rorquals), which at that time were frequently seen in the Bay of Biscay; but as the persecuted animals soon began to grow scarcer, the boldest of the whalers steered north and sought them in their own icy home, where the capture of the rich smooth-back amply rewarded them. Their success naturally aroused the zeal and avarice of the other sea-faring nations, and thus, by the end of the sixteenth century, we find first the English, and then the Dutch, steering north. In 1598, Hull equipped the first vessel for the Greenland whale fishery. In 1611, a society was formed at Amsterdam to commence whaling on the coasts of Novaia Zemlia and Spitzbergen; and as both nations carried on the new trade most eagerly, not only for the profit made by the oil, but because it was regarded as an excellent training school for the sailors, it was soon largely developed. In the year 1661, the Dutch sent out 133 whalers; and between 1676 and 1722, 5886 vessels left their ports, which captured during that period 32,907 whales, whose value may be estimated at least at one hundred million dollars. 
In 1785, 222 English vessels were engaged in the northern whaling trade. Nor were Germany, Sweden, and Denmark, long behind. In 1703, the Hamburg Greenland fleet consisted of sixty-five sail. Frederick the Great, whose attention nothing escaped, ordered whaling ships to be equipped at Emden in 176s. In 1774, the Swedish government gave a company, started at Gothenburg, an exclusive privilege for twenty years; and in 1770, Denmark at length decided on appropriating a portion of the profits which other nations, gifted with greater enterprize and activity, had so long acquired on the coasts of the Danish possessions.

The Biscayans (Bayonne) had, in the meanwhile, fallen greatly astern: in 1735, they only sent out ten or twelve vessels; and in 1744, gave up a branch of commerce which they had been the first to open up with such admirable perseverance.

At the time when Napoleon I. commanded the entire continent, while Britain was the mistress of the seas, the rivalry of the Dutch and Hanse Towns naturally ceased; but the English found more dangerous opponents in North America. At the present moment, no nation carries on the whaling trade with greater zeal and luck than the Americans. According to Dekay, 650 sail, and 13,500 men, were employed, in 1841 , solely in the southern fisheries.

In the year 1848, the American whaler "Superior," Captain Roys, was the first to penetrate through Behring's Straits into the Arctic Ocean, and had a very successful season. The next year, no less than 154 vessels followed his example, and the same number in 1850 and 1851. The icy sea in that part has already produced millions in oil and whalebone. 
Wherever in the whole immeasurable southern ocean the Sperm Whale shews itself, from Chili and Patagonia to the north-eastern coast of Japan, everywhere the Americans are on its track, and prove that in this branch they will, ere long, - share the supremacy of the ocean with the English. Whaling charts were first published by them, in which the captain finds marked in what parts, and at what seasons, the most Cetacea can be found. These charts are, however, not merely a useful direction for the whaler, but they also promise science several explanations about the not yet settled question of the migrations of the whale. While, namely, some writers assert, that the Cetacea are retiring further and further from the pursuit of man, and quitting their usual habitats to fly to still more inaccessible seas, others, like Jacquinot (Zoologie, Voyage de l'Astrolabe et de la Zélée) are of opinion, that though the whalers are continually compelled to seek their prey in new waters, it is not because the whales have migrated, but that they have been almost entirely extirpated in some parts, and hardly at all disturbed in others.

The Greenland whaling was formerly confined to the sea between Spitzbergen and Greenland; nor was it till the beginning of the eighteenth century that Davis' Straits began to be visited. At a later date, the explorations of Ross and Parry acquainted the whalers with new productive stations at the other end of Davis' Straits, and in the higher latitudes of Baffin's Bay. The ships intended to fish there leave England in March, and first visit the coast of Labrador and the entrance of Cumberland Straits, where they carry on what is called the south-west fishery. Remaining there till the beginning of May, they cross to the eastern shore, and fish up- 
wards along the coast, especially in South-East Bay, NorthEast Bay, Hingston Bay, and Horn Sound. In July, they usually sail across Baffin's Bay to Lancaster Sound, into which they at times steer, but frequently advance some hundred miles into Barrow Straits. On their return, they fish along the western coast, where Pond's Bay, Agnes' Monument, and Home Bay, are their principal stations.

In September, the Arctic Ocean is generally deserted by the whalers, though some of them remain till October. The losses are always very considerable. In 1819, ten ships out of sixty-three were lost; in 1821, eleven out of seventy-nine; but 1830 was a specially unfortunate year, for, out of eighty ships, no less than twenty-one were crushed by the ice. The shipwrecks take place, for the most part, on the passage from the east coast of Baffin's Bay to Lancaster Sound, in the attempts to pierce the great ice-bank which almost entirely fills this enormous lake, and opposes an impenetrable wall to the ships till the end of summer. If, during this narrow and difficult passage, the vessel is driven by the drift-ice against the compact pack-ice, its loss is inevitable, with the exception of the rare chance that it is lifted by the pressure out of the water, and sinks again into the sea on the breaking up of the ice. Fortunately, in such shipwrecks lives are rarely lost, for the sea is almost always caln, and the crews have time to save themselves on board other vessels. Whaling is, however, not only a very dangerous and wearying task, but it is also a regular lottery. Sometimes a ship is loaded with oil and whalebone in a very short time, through which the owner of course makes a splendid profit, and the crew are handsomely rewarded; but, at other times, not a single fish has been 
caught by the end of the voyage, and then the crew, whose wages are paid out of a portion of the haul, have had all their toil for nothing, while the owner is considerably poorer. How greatly whaling depends on chance, is clearly seen from the following statement, which we take from an official table. In 1718, the 108 ships of the Dutch Greenland fleet captured 1291 fish, worth about 4,000,000 dollars, or an average to each ship of 36,000 dollars; while, in 1610, 137 vessels unly captured sixty-two fish. The next year, probably owing to this ill-success, only 117 vessels were equipped, which, however, killed 631 whales, and thus repaid the owners in part for the loss of the previous year. Unequal meteorological conditions, winds, temperature, the character of the summer and preceding winter — probably these are the causes of such varying results.

But the South Sea is not a whit inferior to the northern in its freaks. Thus, Dumont D'Urville found in the Bay of Talcahuano several whalers, one of which had procured half a cargo in a short time, while the others had not killed a single whale during twelve to fifteen months. In such cases, the unlucky captains have the greatest difficulty in keeping their crews together, for, deceived in their expectations, they embrace the earliest opportunity for deserting.

The whale fishery has been so often described, that we can confine ourselves to a very cursory account. As soon as a whale is sighted, the boats are lowered very hastily, and the men pull as noiselessly as possible toward the monster. One of them - the man with the sure eye and nervous arm stands up in the boat, harpoon in hand, and when the right moment has arrived, hurls the javelin with all his strength 
into the animal's sides. The wounded whale dives with the speed of lightning, dragging after it the rope attached to the harpoon; but the necessity of breathing soon forces it again to the surface, when a second harpoon is cast at it, followed by a third and fourth on each fresh appearance. Maddened with pain, it makes incredible exertions to free itself from the javelins that are lacerating its flesh; but it is all in vain. From the gaping wounds, "though they may not be so deep as a well, or so wide as a barn-door," sufficient blood flows to exhaust even a whale. Its movements grow gradually more powerless and slow, its panting and snorting more timid; a few convulsive spasms agitate the giant mass - then it drifts senseless and motionless on the water, and the ship is some two hundred pounds richer. If quite convinced of the whale's death - for up to the last moment, a blow of its tail would crush any boat that came too near - it is towed to the side of the vessel, and fastened by chains. The sailors, dressed in leather, and with ice-cramps on their boots, to prevent them slipping off the smooth slimy skin, then get on the captured animal, and cut off the fat in long strips with large axes. After the whalebone, or, in the case of the cachalot, the spermaceti, has been collected, the worthless carcase is left to the current, and a glorious feast is provided for the sea-birds and fishes.

Swarms of arctic petrels and varieties of gulls croak round the bleeding giant; but their pleasure-so rare is perfect fortune on earth - is too frequently interrupted by their troublesome cousin and fellow..diner, the Skua, or great gull (Lestris catarrhactes), which, equal to them in voracity, and superior in strength, forces them to give up the most dainty 
morseis. Albatrosses and sea-swallows fly up in flocks; while sharks and saw-fishes, and all the other brutes that have sharp teeth and impudence enough not to shun the contact of such companions, dive below the water-line.

But the chase does not always end so fortunately as we have described. At times, the whale, in coming to the surface, hurls the pursuing boat into the air, and upsets it; or it succeeds in giving it a hard blow, or else it loosens itself from the rope, and escapes.

Among the Sperm Whales there are some martial gentry, who do not wait to be attacked; but, before the harpoon is cast, rush furicusly on the pursuing boats. Dumont (Whaling Voyage round the Globe), observed one of these dangerous fellows in the South Seas. Swimming up at full speed, the whale first attempted to sink the boat by a blow of its clumsy head; but a clever move of the rudder turned it on one side, and the monster shot past. Turning back again quickly, it attempted to crush the boat between its jaws; but did not succeed, owing to its unfavourable position. The whale, however, renewed the attack with considerable cleverness; it threw itself on its back when a few yards from the boat, and snapped at it with widely-extended jaws. A powerful stab compelled it to close the awful abyss; but it flew against the boat with such force, that the latter was all but upset. Finally, it turned once again on its back, and drove its lower jaw through the boards. Luckily, several well-aimed harpoons put an end to its tricks before it could do more mischief. It was sixty feet long, and full of spermaceti.

Although vessels are only equipped to chase the larger Cetacea, men do not despise the various sorts of Dolphins 
when they come too near land, and give themselves up. The news that a School of Cáing Whales (Delphinus melas) has appeared on the coast, electrifies a whole village in the Ferroe Islands. Old and young run straight to the shore, and a squadron of boats soon puts off to cut off the animals from the open sea. They are slowly driven into a bay, the net draws them closer together, and, frightened by stones and blows, they at length run ashore. In this manner, a large number is often captured in a single day.

Their visits to the coast are, however, very irregular. From 1754 to 1776 , not a single one was seen; but on the 16th August of the latter year, such a blessing (as the islanders rightly call it) was bestowed, that their want was converted into superabundance, as nearly 800 were driven ashore. During the four months Langbye spent on the Ferroes, in the summer of 1817, 623 were killed. The inhabitants paid for half the corn imported with the oil. Langbye was present on one occasion, when forty-six dolphins were killed, each thirty feet long.

The division of the booty takes place in the presence of the bailiff, after the old patriarchal fashion. Each fish is measured, and its size written on its skin in Roman characters. Then the fishes are laid on one side; the largest fish belongs to the boat which first discovered the School; others are bestorved on the poor and the clergy; while the rest is equitably divided between the owners of the coast and the men engaged in the capture. The flesh is eaten either fresh, or hung up to dry in strips; the fat is converted into oil by boiling down, or salted and smoked to be eaten as bacon. 


\section{CHAP'TER II.}

Manatus and Dugongs. - The Rhytina. - Shals and Esmimos. -Menelaus in tile Seal-sinin.-Barbarous Destruction of the Seals in Behring's Sea a nd the Southern Ocean.-Remarirable History of a Sealer from Geneva.-Tine Common Seal.-The Ursine Seat.-Its Paternal Affection.-The Shaggy and Smooth Sea Lion.-The Lelerhant Seal.-The Arctic Warros. - Beechey's Description of a School of Walrusses. - 'The Polar Bear.-Affecting instance of its Love for its Cubs.The Sea Otter.-The Common Otter.

THE transition from the whales to the seals and walrusses is 1 formed by the false or herbivorous Cetaceans-the Manatus or Lamantines of the Atlantic, and the now almost exterminated Dugongs of the Indian Ocean. Like the whale, these

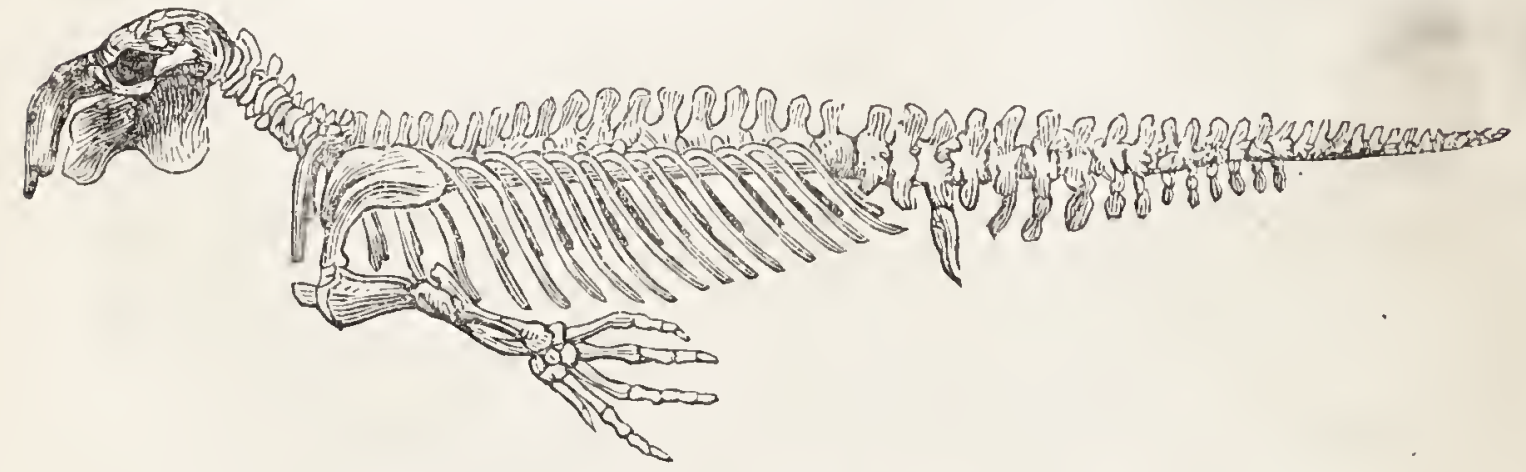

SIKELETON OF THE MANATU.

animals have, instead of hind-legs, a powerful horizontal tail; but are distinguished from them by their more flexile forepaws, on which they rest while feeding on the weeds on shore. When they raise the front part of the body above water, a 
lively fancy can trace a resemblance to the human form. Hence they are also called Syrens, or, from the fully developed breasts of the females, Mermaids; as from the moustache of the males, the latter are called Mermen. In spite of their clumsy form, the vituline countenance wears an expression of calmness and peace.

The Lamantines inhabit the tropical coast-range and streams, both in Africa and America, and attain a length of twenty to twenty-five feet. According to Humboldt, the flesh tastes like ham; and Von Martius declared, that he never ate any pig-meat so good in Brazil. The South American monks consider it a nice fish, and eat the meat with great satisfaction on fast-days. In addition, each animal produces about four thousand flasks of oil for the church lamps and culinary purposes. Thongs are cut out of the thick skin, as well as whips, with which the wretched slaves are punished. As the Lamantine is so useful in many respects, and defenceless and easy of capture, especially at the time of the overflow, when it proceeds higher up the Maranon, Orinoco, Essequibo, Senegal, etc., in search of food and is often cut off, it is in many districts almost extirpated - a fate it shares with the Indian Dugong.

The remarkable "Borkenthier," or Bark-Beast (Rhytina Stelleri; Stellerus borealis, Desm.; Trichechus borealis, Shaw), which the renowned and unfortunate Steller first discovered and described in Behring's Island in 1741, seems to have been entirely erased from the list of living creatures. This sea-monster, which was twenty-three feet in length, and weighed eight thousand pounds, had a black skin an inch thick, which resembled the warty cracked bark of an old oak, scarcely penetrable with an axe, and, when cut through, was 
exactly like ebony in polish and colour. In lieu of teetl, it had, at top and bottom, two long quadrangular masticating plates, six inches in length and three in breadth, between which it rubbed the sea-weed, its ordinary food. The Russians kept up such an incessant chase of the defenceless Rhytina, that in 1768, according to Sauer's report, the last specimen was killed in Behring's Island. It has never been found again, despite of repeated researches and inquiries. History records no other instance of an animal so lately known, and so early destroyed. A single masticating plate, and a portion of the skull, now in the St. Petersburg Museum, are the only relics of this once so numerous family.

The Lamantines and Dugongs are easily tamed in the lagunes and bays of the tropical rivers; but there is reason to apprehend that they, too, will disappear ere man has thought of introducing them among his domestic animals.

The movement of the Phocx on land is clumsy; still they creep along with tolerable speed with their fore-paws, and

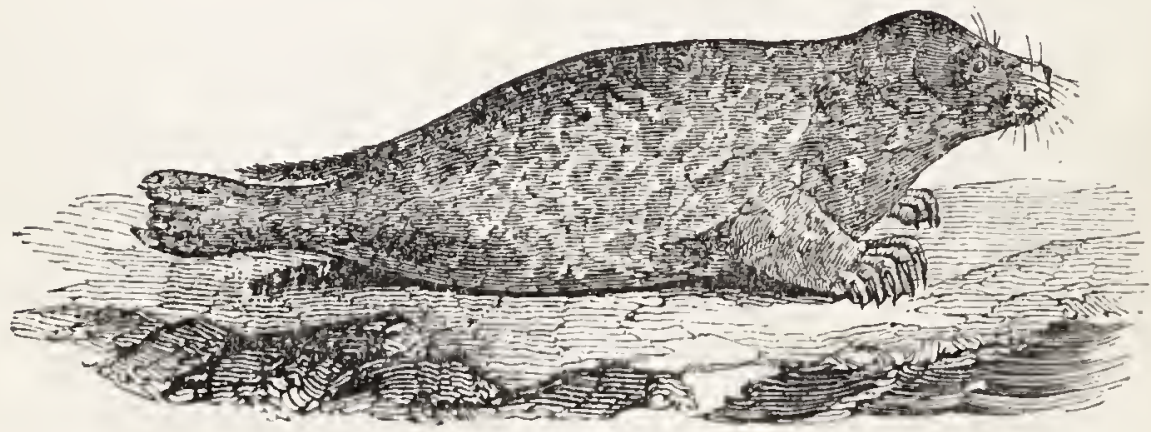

THE COMMON SEAL.

make such huge leaps with their hind-paws, that it is difficult to catch them. Their movements in the water, however, are all the more rapid. Their long body, tapering like a fish toward the tail; the abundance of fat, whose light specific 
gravity facilitates swimming; the position of their feet, which are admirably adapted for steering and paddling; in a word, their whole construction is calculated for an aquatic life.

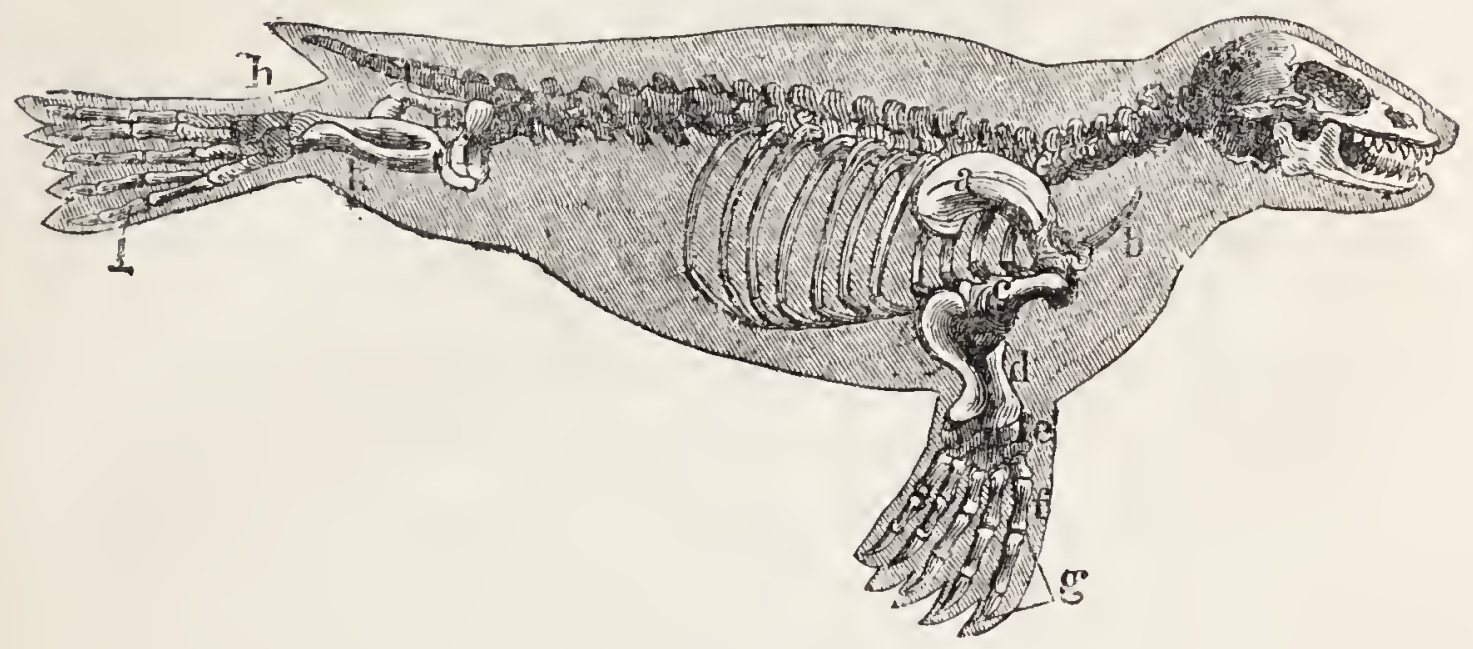

SIELETON OF A SEAL.

$a$ Shoulder-blade, $b$ Breast-bone. $c$ Humerus. $d$ Radius. $e$ Carpus. $f$ Metacarpus. $g$ Fingers. $h$ Tarsus. $i$ Femur. $k$ Tibia, $l$ 'Toes. $m$ Haunch-bone, or Os ilium.

Phocæ are found in nearly every sea, though they principally live on the coasts of the colder regions, and decline in size and number the nearer they approach the tropical regions. Thus, small sea-dogs are found at Surinam; but the powerful ursine seals, sea-lions, elephant-seals, and other huge representatives of the family, are found exclusively in the higher latitudes, on which the sunbeams fall obliquely, and where the winter forms but one long night.

There are also Phocæ in the Mediterranean, but poor little creatures, and few in number; while in $65^{\circ} 50^{\prime}$ southern latitude, animals of this description have been caught weighing 850 pounds; and Captain Renouf, as we read in Dumont D'Urville's Voyages to the South Pole, killed 2000 Phocæ in latitude $81^{\circ}$. 
How strange it is to find the desolate coasts of the Arctic oceans enlivened by such herds of large warm-blooded mammals! But although the ground is only covered with scrubby lichens, the sea is full of fish, which supply the Phocæ with abundance of food. The Merlangus polaris and the Opluydium Parryi in the northern hemisphere, as well as the Nothothenia Phocce discovered by Dr. Richardson off Kerguelen's-land in the southern, try in vain to escape from the pursuit of the Phoca in the little cavities and fissures of the pack-ice; and these small varieties of fish live, in their turn, on the minute crustaceans and molluscs with which the sea is covered in those parts. The Greenland Eskimo, to whom the soil of his rude home supplies not the smallest fruit, has to find his food in the sea; and the Phoca plays the same important part in his simple life-history as the reindeer among the Lapps, or the camel among the Bedouins. The flesh and fat of the seal are his principal food; of its skin he makes his boat, his tent, his roof, and his clothing; of its sinews his thread, his fishing-lines, and the string of his powerful bow; of its bones his rafters, the ribs of his boat, and his needles; and of its bladder the window of his smoky dwelling. But the Bedouin who guards the patient dromedary, or the Lapp who lives on the flesh and milk of the tame rein-deer, enjoys a peaceful life in comparison with the Eskimo, who, to silence the claims of an insatiable appetite, must expose himself to all the horrors of the ocean, and all the terrors of an arctic climate.

At times, he may be seen watching in his boat for hours, amid the frost and fog, till a seal appears on the top of the water, which he at once harpoons; or he waits till the animal 
comes up to breathe at an air-hole in the ice, and transfixes it with his spear. At times, too, he tries to entrap the seacalves sunning themselves on the beach, by approaching them stealthily from the sea, and making a rush at them. Now and then he has recourse to stratagem, wraps himself in a seal-skin, and imitating, with all the cleverness of a savage, the head-shaking and clumsiy movements of the sea-calf, he creeps among his unsuspecting victims.

We read in the Odyssey, that the "tawny hero, Menelaus," in order to catch the changing Proteus, concealed his royal limbs beneath a seal-skin, but could hardly endure the smell. The kind goddess who suggested the mode of catching Proteus, aided him again in this dilemma; she approached the party, and rubbed ambrosia of pleasant fragrance beneath their nostrils, which destroyed the stench of the ocean monster.

Fortunately for the Eskimos, their olfactory nerves are not nearly so susceptible as the nose of the Homeric hero; in fact, they rather like the smell than otherwise. Physical strength, cleverness, caution, presence of mind, perseverance, a sure eye and sharp ear, are qualities in which no Eskimo must be deficient, and they are exercised from the earliest youth. Before he is fifteen, the boy must understand seal-hunting as well as his father, and make all the requisite implements with his own hand. In those inhospitable countries, every man depends on himself; for where the mere preservation of life calls upon all the powers of body and mind, weakness and want of skill are necessarily destructive.

Not merely the wild tribes of the north, however, but civilized nations (who in this respect are true barbarians), chase the Phocæ, or rather carry on the most senseless war of extermination against them. 
Thus, on the Pribilow's island in Behring's Sea, from 1786, the year of their discovery, up to 1833 , no less than $3,178.562$ ursine seals were killed. The discoverers alone killed, in the first two years, 40,000, without taking into account what fell to the share of others. At Unalaska, the depôt for the produce of the Russian chase, there were stored, in 1803, no less than 800,000 skins, more than 700,000 of which were burnt or thrown into the water, probably not to swamp the market. As a well-deserved punishment, the produce fell off rapidly from this moment, until the number of sea-bears became augmented by more merciful treatment.

Still, the English and Americans in the southern seas have no right to reproach the Russians in the north. Since 1815, 40,000 sea-lions have been annually killed on the South American coast, which produced about 2,000 tons of oil; but the number of the animals is now so reduced, that it is scarcely worth while hunting them. Sir James Ross tells us, that the sea-bears and other varieties of the Phocæ were formerly found in large numbers at Kerguelen's-land, which seduced fleets to these desolate islands annually. But after so many years of persecution, the animals have either migrated, or have been almost entirely extirpated.

"There are reasons for fearing," Quoy and Gaymard write, " that, in consequence of the war of extermination which has been carried on against the Phocæ, though now with decreasing zeal, on the coasts of New Holland, they will disappear from the southern hemisphere before all their varieties are known to us." Every year, men are landed from English and American ressels in the bays or uninhabited islands of the South Sea, where the Phocæ mostly congregate, to kill these ani- 
mals, boil down their fat, and pull off their skins. After a few months, the vessel usually returns to fetch the collected stores, and provide the slaughterers, who remain for several years at their solitary post, with fresh provisions. It happens at times, however, that these wretched men are deserted by their comrades, either to rob them of their share of the booty obtained elsewhere, or because, owing to the distance, it is not worth while to fetch them. We can conceive the despair of the deserted men, when week passes after week, and still the expected vessel does not appear on the horizon; when their last provisions are exhausted, and death by starvation slowly creeps upon them! Thus, Dumont d'Urville found, among a horde of Patagonians on the Straits of Magelhaëns, a sealer who, deserted by his companions, had for three months supported his wretched life among these hospitable but half-starving savages. He was a journeyman watchmaker from Geneva, who emigrated to America; but as fortune did not smile upon him in his new home, he listened to the brilliant promises of a whaling captain, and sailed with him from New York to the desert islands of Tierra del Fuego. D'Urville, from compassion, took him with him to Talcahuano in Chili, where he left him to his fate.

On the eastern coast of North America, the capture of seals is still very productive. Newfoundland lies in such a position, that the enormous masses of drift-ice which move in the spring southwards from Hudson's and Davis' Straits must pass its coasts; and on these swimming islands, which frequently enclose small placid lakes, thousands of Phocæ are found. In the month of March, more than four hundred vessels, prepared for their capture, put out from the ports of 
Newfoundland, and boldly enter all the openings in the icefields where the presence of Phocæe is suspected. The crew, armed with heavy cudgels, land on the crystallised ground; and in a few weeks as many as 500,000 of these useful animals have been killed. Even in the Scottish ports, Aberdeen especially, vessels are equipped for killing Phocæ on the North American coast, and they generally return richly laden with oil and skins.

According to the varying number and shape of their canine and molar teeth, as well as the presence or absence of an external ear, the Phocæ are divided into an infinity of families, genera, and species, of which we will merely select the most prominent.

The Common Seal, or German Sea-dog (Calocephalus vitulinus, Phoca vitulina of Linnæus), also called the Sea-calf, owes its first name to the similitude of its face to that of our faithful domestic animal; the second, to the unpleasant sound of its voice. It attains a length of five to six feet. The head is large and round, the neck short, and on either side of the mouth a few strong bristles stand out, as in the dog. It has large quick eyes, no external ear, and a forked tongue. It has six incisors in the upper jaw, four in the lower, a strong sharp canine tooth on either side, and many pointed molars. Woe to the poor herring that enters this mill, for it is irretrievably lost.

The colour of the skin, which is covered with short strong hair is, as our trunlss teach us, as various as that of the ox or horse: brown, yellow, white, black, striped and spotted. As in all the other Phocr, the feet are provided with clawlike nails.

The Common Seal likes the northern waters, and is 
found, in large numbers, at Spitzbergen, Greenland, Labrador, on the coasts of Norway and Russia, in the Arctic Ocean, and on the north-eastern shores of Asia. Formerly, it was met with in the Baltic, on the coasts of England, France, Germany, and Holland, and on the eastern coast of America, not merely to the 21 st degree of latitude, as Dampier asserts, but off Surinam. Towards the South Pole, seals are seen at the Falkland Islands, and at the outermost Antarctic Regions. It is uncertain, however, whether they belong to this or some cognate genera. The movement of the Common Seal on land is clumsy; but in a proper depth of water its movements are extremely rapid; it dives, and appears immediately a great distance off on the water, so that fish can only escape it, by dwelling in the shallowest waters. It can remain under water fifteen minutes, or thrice as long as the most practised pearl fisher. In spite of being such an excellent swimmer, it rarely goes more than a hundred miles from land, where it rests and sleeps. In summer, it likes to sun itself ashore, on blocks of ice, or ledges of rock. 'This peculiarity is often taken advantage of by sportsmen, on the Scottish coast, to greet it with a bullet. If it be not struck, it hurries off at once to its native element, throwing up earth and stones behind it, and evidencing its fear by lamentable groans and yells. If it be caught up and attacked, however, it defends itself to the death with feet and teeth. Its flesh, which is tender, juicy, and fat, and not unlike that of the wild boar in taste, formerly found, like that of the porpoise, a place on the tables of the English nobility. At a banquet given by Archbishop Neville to Edward the Fourth, several Phocæ were served up, which the nobles regarded as a lordly dish. 
The Seal ordinarily gives birth to two cubs, which it suckles for about a fortnight, and then conducts to sea, to give them lessons in natation, and looking for the sea-weed, which will be their staple food for the present. When they grow tired, the parents carry them on their backs. If caught when young, they can be perfectly tamed to follow their master like a dog, and come to him when he calls them by name. According to Pliny, no animal sleeps more soundly; $*$ but more recent observations contradict this; for, according to them, the Seal is extremely watchful, and rarely sleeps for more than a minute, without opening its eyes and looking round to see if there is any danger. It is a question, however, whether this is the case by night, when men do not pursue it, or with the younger animals, happily ignorant of human wiles. At least, we read in Oetker's "Heligoland," that the young seals in that island stretch themselves so cozily on the sand and sleep so soundly, that the Coast-Guard creeps up to them and holds one by the tail, while it snaps away savagely at the air; then he gains a few pence by showing it, and finally, fat lumps for the oil-pot.

Among the ancients, the belief was propagated that sealskins, even after their separation from the body, retained a sympathy with the ocean, and that the hairs constantly bristled at ebb tide; the right foot, too, was supposed to exercise a somnolent influence, so that you needed only to place it under your cushion to be sure of a famous night's rest.

Other remarkable varieties of the Phocæ, are the Harpseal (Phoca-Gröenlandica, Fabricius; Calocephalus Groënlandicus, F. Cuvier), the Eskimos' Alpha and Omega; the * Nullum animal graviore somno præmitur. 
Crested Seal of the Northern Polar Sea (P. barbata; Calocephalus barbatus, F. Cuv.; Le grand phoque, Buffon), which attains a length of ten feet; the Seal of the North Pacific, studded with numerous blackish-brown spots (P. Nummularis); the Ringed Seal ( $P$. annulata), black, with large oval white rings, seen by Parry repeatedly at the ice-holes up to $823_{4}^{\circ} \mathrm{N}$. Latitude, and which is, probably, the most Northern variety, etc.

The Elephant Seal, or Bottle-nose (Cystophora proboscidea; Macrorhinus proboscideus, F. Cuvier; Phoca proboscidea, Desm.; Miouroung of the Australians), derives its name, not only from its size, as it is said to attain a length of twenty-five, and even thirty feet, but also through the remarkable structure of its elongated proboscis, which, hanging down when the animal is quiet, through any emotion is puffed out into a tube a foot in length. This, together with the widely opened mouth, and fearful growling of the animal, is well fitted to frighten the boldest hunter. But defencelessness and weakness are hidden beneath this threatening mask, and a single blow of a cudgel on the snout is sufficient to fell the giant. The Sea-elephant is at home between $35^{\circ}$ and $55^{\circ} \mathrm{S}$. Latitude, in the Pacific and Atlantic Oceans, where it prefers the most solitary islands and coasts. But even on the desolate Kerguelens' Land, sailors have found and extirpated it; for an excellent leather can be made of the thick short haired hide, while beneath is a layer of fat a foot in thickness.

The Crested Seal, or Leather-cap (Cystophora Borealis; Stemmatopus cristatus, F. Cuvier; Phoca cristata, Gmel. and Desm.; Phoca leonina of Fabricius), of the Northern Polar Sea, which only attains a length of seven to eight feet, is dis - 
tinguished by a similar faculty of drawing up the skin from the snout to between the eyes. Then a bladder projects on either side, parted by a firm strip of hide in the centre. But the animal may blow up its skin as much as it pleases; the sealer, for all that, fells it, draws its skin over its head, and throws the fat into the cauldron.

The Otarix, or Eared Phocæ, stand at the head of the family, because their longer and more fully developed feet permit them freer motion on land.

The most valuable of them all is the Ursine Seal (Arctocephalus ursinus; Otaria ursina, Desm.; Ursus marinus, Steller). The black shaggy skin of the animals, from four 'months to a year old, is held "in great repute, and always finds a sure market at Canton. The Russo-American Fur Company now exercises great caution in killing the Ursine seals, at St. Paul, one of the Pribilow Islands, their favourite summer residence. The chase begins at the end of September; and a cold windy day is selected, when the wind is blowing from the quarter where the animals lie. The most daring. hunters, skilled in leaping over stones and rocks, go in advance; then follow the old men and children; last come the overseers, and all are armed with clubs. The great art is to cut the herd off from the sea as quickly as possible. 'The grown animals are driven back and left at liberty; but the young ones are forced inland, sometimes for ten versts, and then killed with the clubs. All the young bears, of the age of four months, are killed; but of those a year old, only the males; the females are carefully taken back to the sea-shore. For several days the mothers will swim round the islands and seek their young with heart-rending moans. 
From October 5, the island is gradually deserted by the Ursine Seals, which proceed southward, and return in April, the males arriving first. Each lands at the same spot it occupied on the previous year, and settles down on the flat stone-covered beach. In the middle of May, the females, who are far more numerous, arrive, and then the season is at its height.

The Ursine Seal attains a length of eight to nine feet, and a circumference of five round the chest; its weight is from eight to nine cwt. It owes its name entirely to its rough black head; but not in any way to a cruel and rapacious temper.

The Ursine Seal is a polygamist, like the Turk or the Mormon, and the number of wives frequently amounts to fifty. The cubs are usually very active, and are fond of playing and wrestling together. When one has thrown another on the ground, the father comes up growling, toys with the victor, trying to overthrow it, and gives the young animal more and more embraces the greater the resistance it offers. It is not so attached to the lazy, idle cubs. These usually hang about the mother. All the cubs remain witl their parents till they are a year old.

The male loves its females and cubs remarkably, but often treats the former with the severity of an Eastern Pasha. He will fight for his cubs, if you try to take them away; but if a mother neglects to pick up a cub in its mouth, and thus loses it, the father's fury is turned upon her. He seizes her by the teeth, and dashes her several times against a rock. So soon as she has slightly recovered, she returns to her lord in a most humble posture, sheds many tears, and crouches at his feet. 
The male walks up and down, growling, rolling his eyes, and throwing his head about; but if he finds that he has no chance of recovering the cub, he begins weeping, too, so violently, that the tears fall in drops and wet his breast. When old, the Ursine Seal is deserted by his wives, and spends the rest of his life in solitude, principally in sleeping and fasting, but generally grows very fat, so that he proves the truth of the French proverb, "Qui dort, dine." Among the virtues of the Sea-bear, its chivalrous sentiments must be taken into account. And it really deserves neither its ominous name nor the cruel persecution of man. If two Sea-bears have a fight, the others form a circle round the combatants, and look on till the victory is decided. Then, however, they take the part of the weaker, at which the heated victor is savage, and attacks the peace-makers. A general melée soon commences; the terrible growling continually brings up fresh combatants, and the sea is dyed with the blood, that flows for many a mile round.

Steller's Sea-lion (Otaria Stelleri), is twice as large as the Ursine Seal; but its dusky skin, covered with short coarse hair, has no value in the peltry trade. It is all the more valuable, however, to the Aleutian, who covers his laidare with the dressed skins; makes his waterproof kamleika of the entrails; employs the web-membrane for his shoes; adorns his cap with the beard, and eats the meat, either fresh, dried, or salted. 'The Sea-lion is found in all the islands of the coast of the Pacific, from $61^{\circ} \mathrm{N}$. Latitude, down to the unknown southern latitudes; but no where in such numbers as at St. George's, one of the Pribilow Islands, where the innumerable herds present a most extraurdinary sight, the clumsy, gigantic masses of 
fat and meat covering a broad, rocky, naked, fat-stained, belt of the strand. The sea-birds (Uria), occupy the free spots on the beach among them; they fly dauntlessly about them, and are not at all alarmed by the growling. A dense fog is generally expanded over the weird scene; and the hollow murmur of the waves is mingled with the croaking of the birds and the growling of the Phocæ, into a most melancholy concert.

Steller's Sea-lion has only some short bristly hair on the neck; but the neck of the southern Sea-lion (Otaria jubata; Platyrhyncus leoninus, F. Cuv.), bears a regular mane. The whole of the body is covered with short smooth hair. The lioness is of a rather darker color than the lion, but has no mane. The pectoral fins look like large pieces of black, tough, leather, and are armed with almost imperceptible nobs instead of claws. The back fins bear a close resemblance to feet, and the five toes are provided with small nails. A fearfullooking animal, ten feet in length! And well may the naturalist start back in terror, when, in walking through the tall Tussack grass of the Melvines, he suddenly sees such a giant seal before him, which salutes him with widely expanded jaws and a terrific growl!

The Arctic Walrus comes next to the Phocx in the succession of the creation, as it is more fitly constructed for the water than the land.

It has no front teeth, and the molars, like those of herbivorous animals, are flat. This evidences difference of food, and the Walruses live chiefly on sea-weed and molluscs; while the Phocæ are such tremendous fish-consumers, that Sir James Ross found in the stomach of a sea-calf, beyond the 
southern Polar circle, no less than twenty-eight pounds of undigested fish. In the place of canine teeth, the Walrus has two tusks growing out of the upper jaw.

The Arctic Walrus (Trichechus Rosmarus) is one of the largest of these animals, for it grows to a length of eighteen feet, and measures twelve feet round the middle of the body. Its form is very awkward; for it has a small head, a short neck, a thick body, and stumpy legs, terminating in broad, fin-like feet. Hence it is not surprising that it moves very clumsily on land. It raises and sinks its head alternately, like a large caterpillar, to facilitate the advance of the hinder part. The upper lip, which is very thick, and parted in the centre, is covered with half-transparent yellow bristles, three inches long, and about as thick as a straw, which do not add to its personal appearance. Under this lip emerge two powerful tusks, which, like those of the elephant, grow out of the upper-jaw, but are bent downwards. They are also intended for a very different purpose; for while the elephant employs his tusks to tear up the ground and dig out roots, the walrus, with their assistance, lifts its helpless body on to lumps of ice, when it desires to sun itself. For both animals they are a terrible weapon, defending the elephant against the bounding tiger, and the walrus against the greedy shark and hungry Polar bear. The walrus is slaughtered, not only for the sake of these tusks, which are finer, closer, and whiter than ivory, and excellently adapted for artificial teeth, but also for its rich oily fat, and its inch-thick hide, out of which a very strong elastic leather is prepared.

The walrus is found in Behring's Strait, Spitzbergen, Novaia Zemlia, the Bear Island, and Jan Mayen. It is the 
sole support of the most northerly dwellers on the earth, the Eskimos of Prudhoe-land, as well as the Tschuktschi, who skirt the eastern promontory of Asia. A huge massacre of walruses takes place annually on the northern coast of the Alyaskan peninsula. They lie there on the outer edge of the coast, which, in high spring-tides, is under water. When the Aleutians set out to kill these animals, they take a solemn farewell of their families, and prepare to meet death; for they fear not only the tusks, but also the carelessness of their comrades. Armed with spears and heavy axes, they creep along the coast to the spot where the animals are encamped, then take their posts a short distance apart, and rush with yells on the walruses, to drive them inland. They take great care lest a single one escape into the sea; for, if this happen, the others are sure to follow, and the hunters run a risk of being crushed. When the walruses are driven far enough from the coast, the hunters attack them with raised lances, and seek to stab them in those parts where the hide is thinnest: then, leaning their chests on the spear, they turn it round several times, in order that the wound may become large and mortal. The animals fall a-top of each other, and at length form huge piles; while the hunters positively wade in blood. The jaws of the victims are cleft asunder, and the tusks removed, for the sake of which from 2,000 to 4,000 of these. animals are annually killed. The first high-tide washes away the carcases, and destroys every trace of the butchery. The next year, the north sends fresh victims.

The Walrus is a harmless gregarious beast, save when attacked or annoyed, when it is easily roused to intense fury, and evinces extreme savageness. If a herd be suddenly sur- 
prised, the young are first thrown into the water, and taken to a safe place; after which the elder animals return, with terrible growling and gnashing of teeth, to upset the boat, or tear it asunder with their tusks. Beechey describes how a large herd of walruses, led by a very bold and powerful animal, attacked the boats of the "Dorothy." A musket thrust down its throat and fired, mortally wounded the leader, on which the others fell back. But they did not leave their commander on the battle-field; they swam off, supporting the dying animal in the water with their tusks, to prevent it sinking. A young animal, not yet tusked, alone remained with the boats, and continued the attack. It was driven back with whale-lances (for they did not wish to kill it): and though bleeding from numerous wounds, it soon crept on the ice after the sailors, as if anxious to pursue them. Never was such mutual or more affecting devotion shewn than by these animals; and we cannot deny them either intelligence or feeling. Captain Cook, in his voyage, gives an equally interesting account, to which we refer our readers.

The Polar Bear (Ursus maritimus, Thalarctos of Gray) may also be reckoned among the aquatic mammals; for it seeks its food principally in the water. It is distinguished from the common bear (which it exceeds in size and weight, as it attains a length of nine feet and a height of four), not merely by its white hairy skin, but also through its elongated neck. Its five toes, partly connected by a strong web, indicate its relation to the sea. It swims at the rate of three miles an hour, and dives for considerable distances. On land, it also moves with great ease, runs on level ground twice as fast as a man, and often surprises its prey by moving noiselessly over the snow. It 
lives mainly on fish; but attacks seals, birds, foxes, rein-deer, and even men, after a long fast. On the other hand, it is chased by the bold inhabitants of the high north, who do not despise its flesh, and employ its skin for various purposes. It is found within the Arctic Polar circle, on the coasts of Greenland, Novaia Zemlia, and the coasts of Siberia. Spitzbergen and the other neighbouring islands of the Arctic Ocean swarm with them. Some at times come on lumps of ice to the northern coasts of Iceland and Norway, as well as to Labrador, or so low down as Newfoundland. We find an interesting instance of its ferocity mentioned in Manby's voyage to Spitzbergen. A Captain Lewis, with five other men, attacked a Polar Bear; and, when about forty paces from the animal, four of them fired simultaneously, and wounded the animal. The infuriated monster rushed upon them open-mouthed; and, as it approached with fierce howls, the other two men, who had refrained from shooting, fired together, and broke the bear's shoulderblade. But ere they could load again, the bear was close on them, and they were forced to hurry down to the beach, during which it almost caught them, in spite of its lameness. Two of them jumped into the boat: the others hid themselves behind lumps of ice, and fired at the brute as fast as they could load. Thus it received several wounds, but they only served to heighten its fury; and at last it drew so near two of the men, that they were forced to leap into the water from a perpendicular rock twenty feet high. The bear leapt after them, and had almost caught the hindmost man, when strength at length failed it. When dragged ashore, it was found to have received eight bullet wounds.

This otherwise so savage brute has a most tender heart for 
its cubs. When the "Carcase" frigate (in which, by the way, Nelson began his naval career) was beset by the ice in 1773 , during a voyage of discovery to the Polar regions, one morning, the sailor in the crow's-nest announced that three bears were coming at great speed across the ice, in the direction of the ship. Doubtlessly, the smell of a fire, in which a seal had been burnt, attracted them; for they immediately fell on the partially carbonized remnants, and greedily devoured them. The sailors then threw several large pieces of sealflesh on the ice, which the mother carried to her cubs and divided between them, keeping little for herself. As she carried off the last piece, the sailors fired at the cubs, and killed them both - the mother being also severely, though not mortally, wounded. It would have drawn tears of compassion from the most unfeeling heart, to see with what loving anxiety the poor mother watched the dying moments of her cubs. Although herself scarce able to reach the spot where they lay, she carried them the piece of meat she had fetched, laid it before them, and, on seeing that they would not eat it, she tried to raise them in turn with her paw, groaning lamentably the whole time. When she found that she could not induce them to get up, she went away, then looked round and groaned; but, as this was of no use, she returned and licked their wounds. After this, she retired again, and, crawling a few paces further, looked round, and paused for awhile. But, as the cubs would not rise, she returned once again, crept with signs of extraordinary tenderness first to one and then to the other, patting them with her paws, and whining dismally. When at length convinced that they were cold and helpless, she raised her head to the vessel, and uttered a howl of despair, 
to which the murderers responded with a volley of musketballs. The bear fell between her cubs, still licking their wounds.

We will conclude our rapid survey of the marine mammalia by a few words about the Kamtschatkan Sea Otter (Enhydris marina; Lutra lutris, Geoff.; Lutra marina, Erxl., Desm.; Mustela lutris, Linnæus). This animal's habitat is between the 50th and 56th degrees north latitude, on the coasts of Behring's Sea and the North Pacific, and it is most frequently found on islands. It feeds on all sorts of fish, crabs, mussels, periwinkles, and, if needs must, on sea-weed. It dives, like the Phocæ and Walrusses, but cannot remain so long under water. Its fine long black-haired or silver-grey skin produces the finest of all peltry, the ornament of the Russian prince and the Chinese mandarin of the first class. Four hundred to five hundred roubles have been paid for an extraordinary fine skin. The Sea Otter possesses, besides, some historical interest; for without it the Russians, its pursuers and exterminators, would have hardly advanced from Ochotzk to Kamtschatka, and thence across the Aleutic chain to the American coast. Incessant pursuit has rendered it a rare animal; but the race is said to have augmented lately, as the Russians have been more saving of it.

The Common Otter (Lutra vulgaris), usually found on the banks of all European rivers, and which stands in bad odour for the ravages it commits among fish, takes at times to the sea. It has been seen in the neighbourhood of the Orcades, enjoying cod and oyster-sauce. 


\section{CHAPTER III.}

Astounding number of Aquatic Birds.-Shore Birds.-Cunning of time Plover to entice the foe from its Nest.-Migrations of the Strand Birds.-Aquatic Birds generally.-Anatide. - The Eider Duck.-The Long-talled Duck. - The Grey Duck of the Falizand Islands.-The Rock Goose.-Auks and Penguins.-The Cormorant-Fishing in China.-The Frigate Bird. - The Gulls. - Stormbirds. - The Albatross - Birdcatching at St. Kildda.-The Guano of the Cinncha Islandos.

$\mathrm{W}^{\mathrm{B}}$

E read marvellous stories of the wild pigeons spread over the whole of North America, which collect in countless swarms, in the spring before breeding-time. The ornithologist, Wilson, observed one of their enormous flights, which began crossing over his head just at mid-day. He stopped, and saw the flock momentarily increasing in size and speed. After an hour, the naturalist proceeded in the opposite direction, crossed the Kentucky River, at Frankfurt, about four o'clock, and the sun was still dimmed by the swarm. At five o'clock, the first interruptions occurred in the dense mass; but the last stray files were not out of sight, till ten in the evening. Wilson reckoned the number of birds at 2,000,000,000; and similar swarms were seen by him at various times in other parts of North America.

We are astounded at such numbers of a single land-bird; and yet is doubtful whether wood or plain support so many of 
the feathered race, as the fish-producing sea. For every rocky island in the immeasurable ocean, every point jutting out above the water, is a refuge for myriads of sea-birds; every coast, from the poles to the equator, is populated by their countless legions; and, far from any land, their flocks hover over the deserts of the sea. Many, unskilled in swimming, seek their food on the coast; others rival the fish in speed on their native element; and others, again, gifted with an unwearied power of flight, seek their prey in blue water. But though the habits of the various families of sea-birds may differ so greatly, each of them is most perfectly formed and equipped for its peculiar sphere; each is an unsurpassable masterpiece in its way. Both on account of the admirable adaptation of their structure, and the important part they play in oceanic life, these birds deserve our attention; while they attract our interest, in a high degree, by the use mankind can turn them to. Many an island population depends on them for the greater portion ofits food, while guano has recently become of the utmost value to Europe.

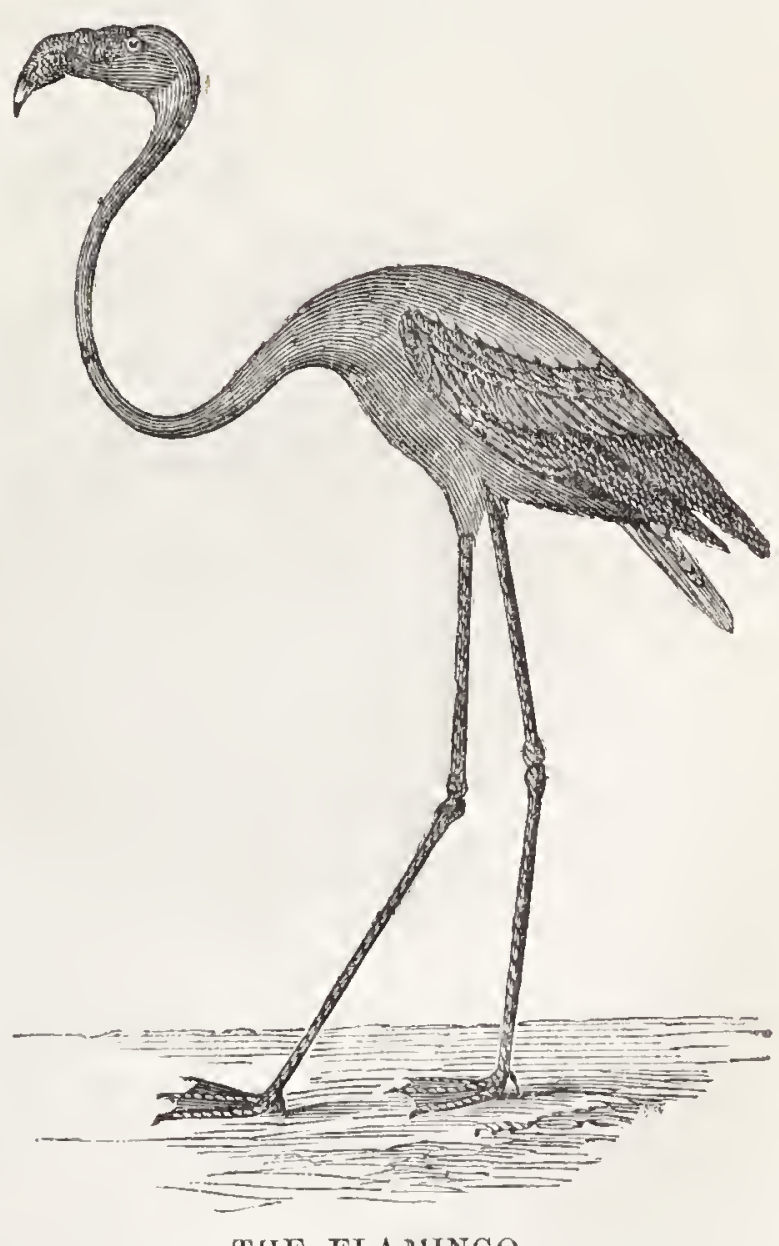

THE FLAMINGO.

We will first survey the Strand Birds, which live on the 
verge of the ocean, and on the beach deserted by the tide, or seek their food in a low depth of water. How famously is their form adapted for the territory allotted to them, for the soft yielding ground they are intended to tread! The slight weight of the graceful body, and the long thin legs, allow them to wade with ease through the slime, and grasp the worm ere it has time to bury itself; and to spare them the annoyance of repeated stooping, they have a long moveable neck, by the aid of which they rapidly and easily seize their prey.

The wonderful art with which the feathered denizens of the wood build their nests, the patience with which they collect the raw material piecemeal, and spare no pains to prepare a

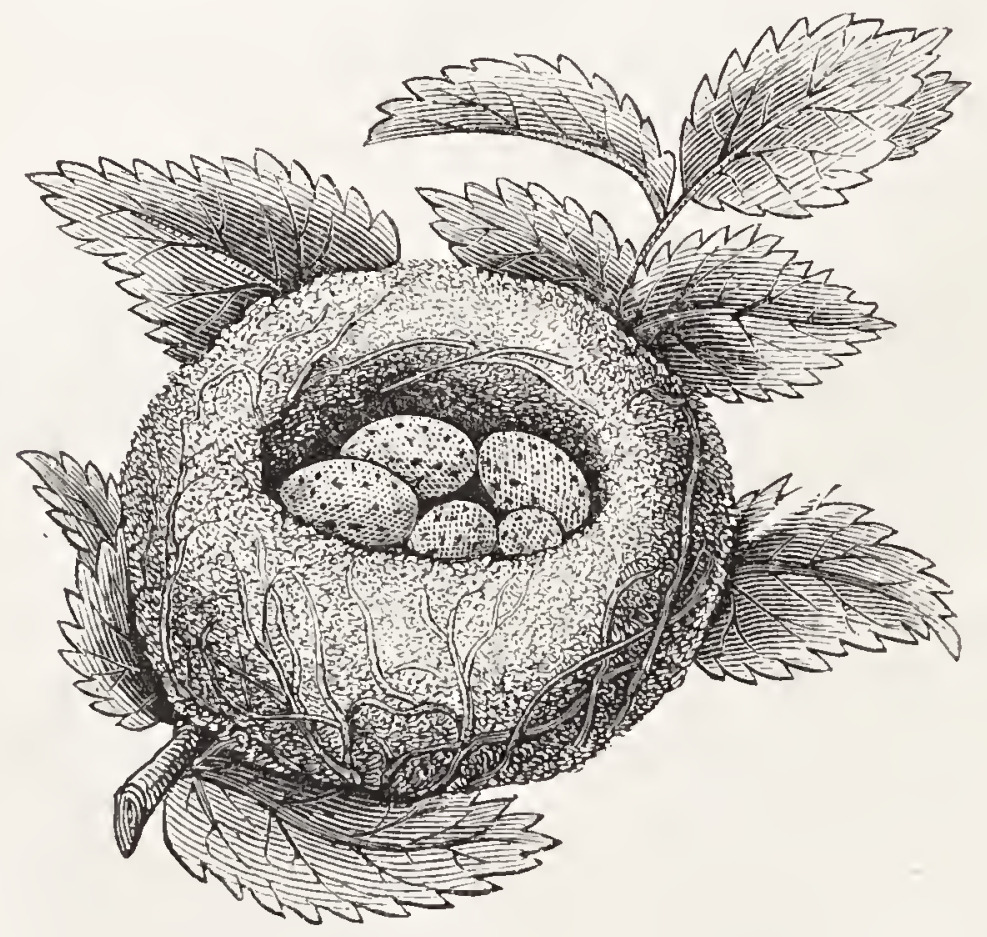

A LINNET'S NEST.

soft bed and secure a cradle for their coming brood, may be hought in vain among the strand-birds. Thus the Plover (Charadrius Hiaticula) contents itself with digging a small hollow in the sand, just above high-water mark, and broods 
on its four eggs on the open strand, without any other protection or preparation. But who instructed it to arrange them with the narrow end round a centre, so that they shall occupy the least possible space? No mathematician could have solved the problem better. And yet this instinct is not so remarkable, as that which bids the Sylvia Sutoria to sew leaves together, in order to conceal her brood from the enemy.

Most moving is the affection of the Plover for its young. When dogs or mischievous boys approach its nest, it does not await their arrival, but boldly goes a few paces to meet them. 'Then it

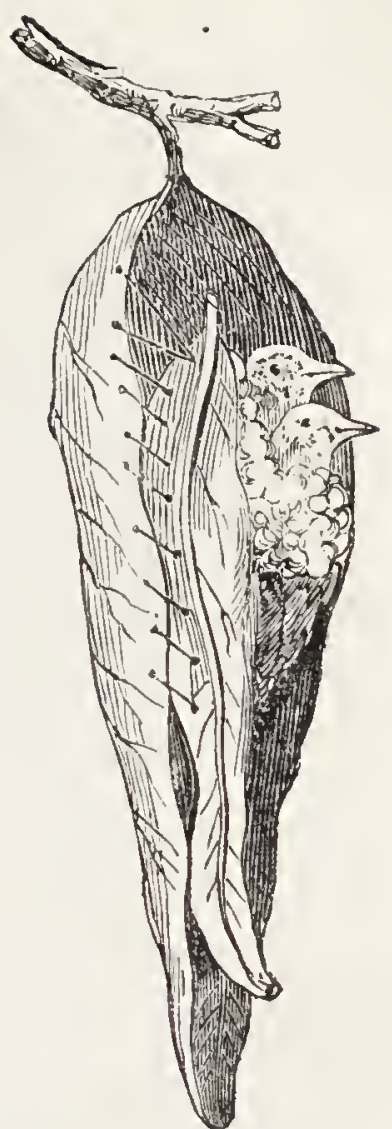

TAILOR-BIRD'S NEST.

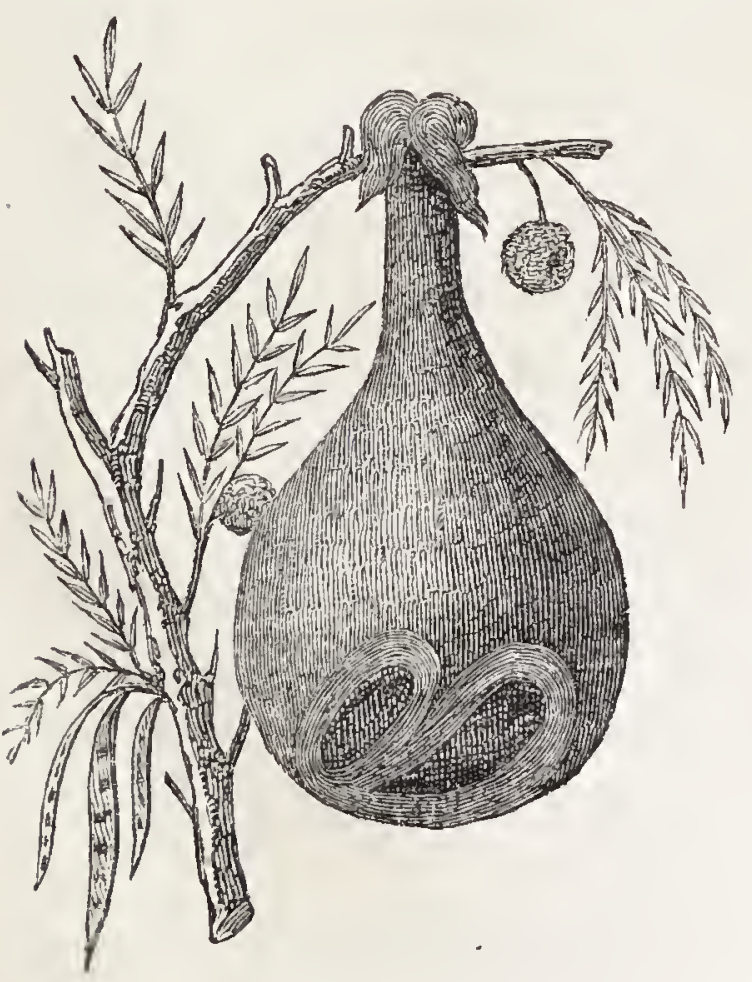

A BOTTLE NEST. suddenly rises, with a loud cry, as if just startled from its nest, although this is probably a hundred yards off, and flutters, apparently lamed, along the ground, to draw the danger further from its beloved young. The dogs, in the hope of catching it every moment, run after it; till, all at once, the crafty bird shoots away like an arrow, 
and leaves its pursuers staring after it open-mouthed. 'The Peewits and Tirmæ employ similar stratagems to protect their brood. In New Zealand, the naturalists Quoy and Gaymard were cheated by one of the latter, which, when they shot at it, pretended to be wounded, and, with hanging wing, led them from the right track.

All the strand-birds of the high north fly when winter approaches to the coast, where milder breezes blow. But when summer begins to unfold its glory again, the desolate coasts of the Polar Sea are enlivened by myriads of plovers, curlews, herons, water-rail and phalerops, to which the freshly thawed coast opens a rich larder. But the low temperature soon hardens the ground anew; want succeeds abundance, and the longlegged army hastens to quit the northern districts, which oppose an ice corslet to their beaks.

There are strand-birds which stay only a few months at

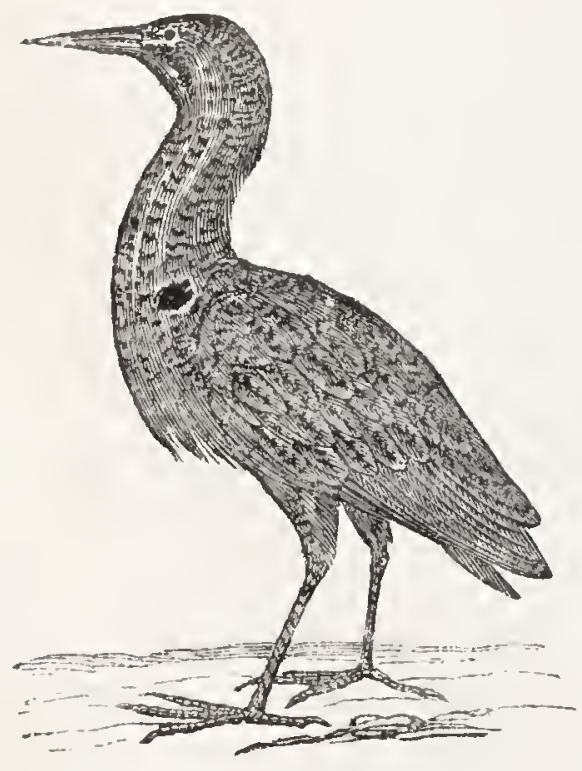

TIIE CURLEW. the sea-side, and spend the rest of the year inland. They are fond of a change of air, like fashionable folk. The common curlew, however, behaves very differently from the visitors to our watering-places; for it leaves the beach in spring, after spending the winter there, indulging in crustaceans and varieties of annelids. In summer, it inhabits retired moors, and changes its diet to frogs, worms and newts.

The food of the strand-birds varies, however, very greatly; 
and thus their beaks are of different shapes. Those among them that live on worms, have generally a long, thin, boring beak, to peck the food out of the loose sand or mud. If the little animal crawls under a larger stone, it is secured against their attacks; but then comes the Interpreter (Tringa Interpres), with a slightly upturned beak, who upsets the stone, and falls upon the exposed garrison.

The Wedge-beaked Tirma (Hcomatopus Ostralejus) behaves in a similar way with the mussel-shells it finds washed up on the beach, and under which it hopes to find worms. Still more extraordinary are the manœuvres of the Black Skimmer (Rhynchops nigra), which principally inhabits the hot coasts of America. The beak is unparalleled in its way; the upper mandible is an inch shorter than the lower, as if it had been broken off; while the lower is not channelled and is of a wedgelike shape. A curious instrument, which the bird, however, manages to use very skilfully. The sandy beach of Penco, Lesson tells us, is full of cockles (Mactra), which are left high and dry at the ebb in small pools. The Black Skimmer sits down by them, waits till the shells are slightly opened, and immediately thrusts in its lower beak, on which the shells close. It then takes up the shell, beats it on the sand, and swallows the mussel with the same pleasure as we do an oyster. It also finds food in the sea. Flying slowly over the water, it scoops up the smaller fish and prawns. Thus, on all the flat sandy coasts, there is nothing hard or soft, creeping or swimming, hopping or running, which has rot its appointed enemy among the strand-birds. On the other hand, the strand-birds are of no special service to man, save that some of them are dainty eating. 
Far more important are the sea-birds proper, which are adapted for incessant swimming or diving, or for long flights across the sea. Their flat broad-webbed feet, and their short muscular legs, close to the rear of the body, serve the swimming birds as famous oars, although many find it difficult to walk on land in consequence. Everything that exists on the sea must naturally be protected against rain and storm by a thick seaman's coat; and everything swimming, with a waterproof cape. For both, nature has abundantly provided in the Palmipedes, or swimming-birds. They all possess a large gland on the top of the tail, from which exudes an oily matter, with which they daub their feathers, and make them impenetrable by wet. Their plumage is remarkably close and thick. and the duck and diver varieties are also provided with a warm underskirt of soft down, which is eventually secured by man, the universal robber.

The Anatida, or sea-birds of the Duck family, remain during the summer in the higher latitudes, and in the winter proceed south in enormous flights. Some remain the whole year among us; others, only during breeding time; while others, again, the real birds of the Polar sea, are very rarely or never seen by us. Most of the Anatidx, it is true, prefer to live on lakes and rivers, in ponds and marshes; but many of them are true sea-birds, and spend a large portion of their time fishing and swimming in the sea.

The Eider Duck (Anas mollissima), which is twice the size of the ordinary duck, inhabits the higher latitudes of Europe, Asia, and America. One of its most famous breeding-places is the small island of Vidoë, near Rejkiarik (Iceland). They are protected by the laws; and any man who kills one of them 
must pay a heavy fine, amounting to thirty dollars for each bird during the breeding season.

Mackenzie, in his "Voyage through Iceland," tells us, that when his boat approached the shore, it passed through flocks of this handsome bird, which rarely took the trouble to get out of the way. Between the landing-place and the house of the bailiff, the ground was covered with them; and the visitors were obliged to walk cautiously, lest they might tread on them. All round the house, on the garden walls, on the roofs, in the interior of the houses, and even in the chapels, they were sitting on their nests. Those which had not been brooding any length of time, flew off when the strangers arrived; but those which had more eggrs did not stir, allowed themselves to be patted, and gently pecked at the strangers' hands. Their nests were lined with down, which the bird pecks from its own breast. Round the nest was a sufficient quantity of feathers to cover the eggs when the mother went out in search of food, which was usually at ebb-tide. The down is taken from the nest at two different periods, but the poor duck is sometimes compelled to supply a third crop. When the female has exhausted her stock of brownish down, the male bird sacrifices his splendid coat of snow-white and rosy down for the welfare of his young. A certain number of the eggs, which are considered great dainties, are also taken. Mr. Mackenzie says, they are tolerable when boiled, but much inferior to hen's eggs. When the down is taken from the nests, it is mixed with feathers and straw.

Sorting the down, and preparing it for sale, is part of the winter employment of the gentle sex. About a quarter of a pound of cleansed down is obtained from each nest. The 
softness, lightness, and elasticity of these feathers, is universally known. A few handfuls of compressed down suffice to fill a counterpane, beneath which the northern can defy the severest cold of winter. So soon as the young have crept out of the eggs, the duck takes them on her back, swims out with them some distance, and then dives, leaving the little ones to practise swimming. When they have learned the use of their feet, the duck returns, and becomes their guide. Various broods, often in large numbers, join, and growing quite wild, disappear, and no one knows where they go. This bird is also found in the Shetland and Orkney Islands, and it broods on May Island, at the mouth of the Frith of Forth. They are also seen at times on Heligoland, but do not breed there.

The Greenlanders follow the Eider Ducks in their small boats, and kill tliem with spears so soon as they rise to the surface, as their track is traceable by the bubble. The meat serves them as an agreeable change from their ordinary seal; and they make very comfortable under-garments of the skins, turning the downy side in.

The Long-tailed Duck and the Wild Duck (A. glacialis, $A$. tadorna) also inhabit the northern coasts of Europe, Asia, and America. The former remains sometimes the winter through in the high north, and dares the icy winter of the Arctic circle. Several often proceed south so soon as the cold season sets in, and wander from Greenland and Hudson's Bay as far as New York, and from Spitzbergen and Iceland to Heligoland and the Schleswig isles. The female bird also lines her nest with plucked down.

In winter, the Wild Duck often appears in Western England, especially in Ireland, where it is caught in nets. At 
Sylt, on the Schleswig-Holstein coast, it is regarded almost as a domestic bird; artificial caves are dug for them, and they brood in holes in the walls of the villages. Naumann saw here thousands of wild ducks, sitting in couples on the ground, so tame, that they allowed him to come within twenty paces of them before they rose. He also admired the arrangements made for the ducks; and he noticed as many as thirteen nests in one quadrangular bed, with a common entrance, and connected by under-ground pipes. Above each nest is a perpendicular hole, covered with a piece of turf. On lifting this, you often find a duck sitting, so tame, that it allows itself to be patted. Every inhabitant of the little village has several such places, from which he takes daily during three weeks from twenty to thirty eggs, leaving six behind for incubation. Beforehand, however, he removes half the beautiful light-grey down, which is as light and valuable as that of the eider duck.

A very curions member of the Anatid family is the large grey Goose (Anas cinerea, or brachyptera) of the Falkland Islands, which attains a weight of thirty pounds. The wings are too short and weak for flying; but, with their aid, the bird skims rapidly and with a loud noise over the waves, which it beats with its wings - a peculiarity which has procured it the name of the "Race-horse" or "Steamer."

It lives on shell-fish, which it finds on the rocks, or picks off the sea-weed; and to crush them, is gifted with such a hard head and beak, that it is scarcely possible to break them with a geologist's hammer.

Another remarkable inhabitant of the southern hemisphere is the Rock Goose (A. Antarctica), which is only found on 
rocky coasts, and may be frequently seen on the Faulkland Islands and the west coast of America, up to Chili. The snowy gander, with his darker-hued mate, is found often sitting on some lofty peak in the deep and solitary bays of the Tierra del Fuego, and they form a most striking feature in the landscape.

The Divers, or Colymbidæ, are nearly related to the Anatidæ; but are distinguished from them by their long conical beak, and the legs being still further back; so that, when the bird leaves the water, it is forced to stand almost upright to preserve its balance.

Still more noticeable, is this upright position in the family of the Auks (Alcidce), which seek their food by swimming and diving in the sea, and then digest it in all comfort on rocks. Their wings are short, and small in proportion to their bodies; and in some species are so little developed, that they are quite unfitted for flying. In this and certain other points, this group bears a singular likeness to the Penguins of the southern hemisphere, in which the imperfect formation of the wings, and the skill in diving and swimming, are most strikingly shewn.

In the water, the Penguins employ their little unfeathered stumps of wings as fins; on the land, as fore-feet, and by their aid clamber up the grass-grown rocks with such rapidity, that they may be easily taken for quadrupeds. When swimming in the water the Penguin dives and rises again so rapidly, that at first sight it is frequently taken for a playful fish.

The other sea-birds, in swimming, usually keep a portion of the body out of the water. This is not the case with the Penguin, which only allows its head to be visible; hence it 
swims with a speed and perseverance which beat many of the finny tribe. How greatly it feels at home on the sea is shewn by the fact, that Sir James Ross saw two Penguins in $58^{\circ} 36^{\prime}$ south latitude, a thousand miles from the nearest land.

This strange bird is found in countless numbers on many uninhabited islands in the higher latitudes of the southern hemisphere. Ross found not the slightest trace of vegetation on Possession Island, which he discovered in $71^{\circ} 56^{\prime}$ south latitude, but the entire surface of the island, up to the tops of the hills, was covered with Penguins, which boldly attacked the English with their sharp beaks when they tried to force through their dense ranks, and fought with them for the country they wished to occupy in the name of Queen Victoria.

This reception, as well as the terrible croaking of the birds, - of which an idea can be formed, when we state that the voice of the Penguin rivals that of the donkey in volume and pleasantness; and then, too, the atrocious stench of the deep guano layer, which had formed there in the course of centuries - soon drove the sailors from this new possession of the English crown, which is unfortunately situated in too inhospitable a sea for its rich store of guano ever to be removed.

According to Duperrey (Voyage de la Coquille), the Falkland Islands swarm with Penguins. In summer and autumn they leave their holes early in the morning and in the afternoon, and go to fish at sea. After filling their stomachs, they stand for some time on the shore in groups, one bird trying to outvie another in shrieking, and then all retire to rest in the tall grass, or in their caves.

Lesson says, that on fine summer evenings - which are, 
however, rarely met with at the Falklands - at the moment when twilight sets in, all the Penguins utter a loud cry together. Hearing this noise from a distance, you can easily believe that it is produced by some popular commotion.

When the young birds have grown sufficiently, the whole band quit the islands, and go to the open sea. No one knows in what direction they proceed. Sailors, who have passed entire years in those waters, believe that they spend the winter on the water. This agrees with Ross' observations; for on the 4 th December, he saw, in $49^{\circ}$ south latitude, a flock of Penguins on the high seas, undoubtedly proceeding to their brooding-places. He was amazed at the wondrous instinct of these birds, which guides them hundreds of miles across the pathless ocean to their usual homes, so soon as summer approaches.

The migration of the Penguins takes place suddenly. "We were no little amazed," Duperrey writes, "when we went to observe them for the last time, at finding only a lame invalid on the spot where the day before we could have counted them by thousands." Then the shores of the Malvine islands appear as solitary and deserted as those of a watering-place when the season is over. Duperrey estimates the daily quantity of fish required by the Penguins on the Falklands at 50,000 lbs., and believes that he is rather below the mark; as the maw, when full, contains two pounds, and the birds are so greedy that they are frequently compelled to disgorge. The long maw extends to the lower part of the stomach, and the entire length of the intestinal canal is twenty-five feet, fifteen-fold that of the body; so that nature has evidently calculated on an excellent appetite, sliarpened by sea-air and bathing. How 
stocked with fish must the sea be that supports such an army of guests!

There are several varieties of the Penguin; the largest Aptenodytes antarctica) is at least 180 lbs. in weight. It is a rare bird, generally found alone; while the smaller varieties are always in immense flocks.

Below $77^{\circ}$ south latitude, three of these gigantic birds were captured by Ross, the smallest of them weighing fifty-seven pounds. Their food consists of fish and crustaceans, to pound which the lumps of quartz, granite, and trapp, weighing ten pounds, which Ross found in the maw of one of them, are probably employed. The Penguin, like its northern relative, the Auk, lays only a single egg. Its rather agreeable flesh is of a black colour. The Penguin is protected against the Arctic cold, not merely by its close-lying feathers, but also by a coating of fat beneath the slin.

In the Bay of Callao, Humboldt's Penguin (Spheniscus Humb.) is repeatedly met with. It is somewhat smaller than the common grey bird, and of rather a different colour on back and breast. The Peruvians call it Pajaro Nino (child's bird), and love to keep it in their houses; for it can easily be tamed, and follows its master like a dog. Very laughable is the appearance of the stumpy form, as it waddles across the street on its short feet, and moves its fin-like wings rapidly to maintain its balance. Tschudi kept one of these tame birds, which always obeyed its master's call. At dinner, the stiff-necked fellow stood regularly by his chair, and slept at night under the bed. When Pepe wished for a bath, it would go into the kitchen, and tap with its beak on a water-jug, until some one poured the contents over it, or prepared a bath. Among the Pelican family, which are principally distin- 
guished by a swelling of the skin below the hooked beak, which serves them as a larder, we may reckon the Cormorant (Phalacrocorax carbo), the Frigate Bird (Tachypedes aquila), and the Gannet (Sula Bassana).

The Cormorant, with its long curved beak, black livery, and yellow pouch on its back, is a very repulsive fellow. It exhales a more unpleasant odour than any other bird, and its flesh is even despised by the anything but dainty Eskimos. In spite of its voracity, it always remains thin and lean - the

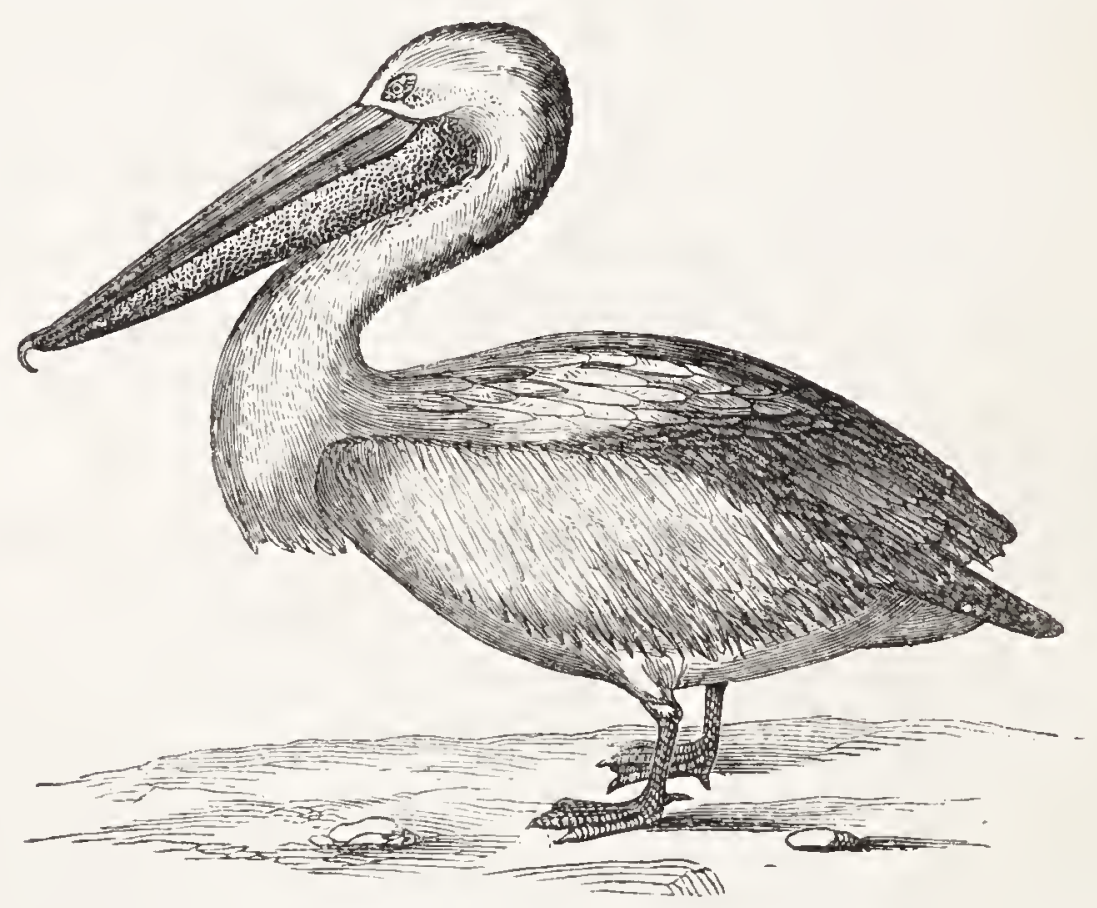

THE PELICAN.

image of a hungry parasite. But it understands fishing in a first-rate way, and was formerly tamed and trained for this purpose in England. A cognate variety (P. sinensis) is still employed for a similar purpose in China, as Fortune describes in his most amusing work.

The Band Cormorant (Carbo Gaymardi) owes its name to the broad white band it has along either side of the neck. Its plumage is grey and white, the beak yellow, the feet red. 
We allude to these birds more especially on account of their remarkable eye, for the Iris is composed of regular quadrangular white and green spots.

The Frigate Bird soars over the tropical waters. In proportion to the bird's height (three feet) its wings surpass even those of the Condor in length; for, when extended, they measure fourteen feet from one tip to the other. It flies in the highest regions of the air, so that it can be hardly seen with with the naked eye, and swoops like an arrow on the luckless fish, which have been only that moment driven from the water by the Bonita.

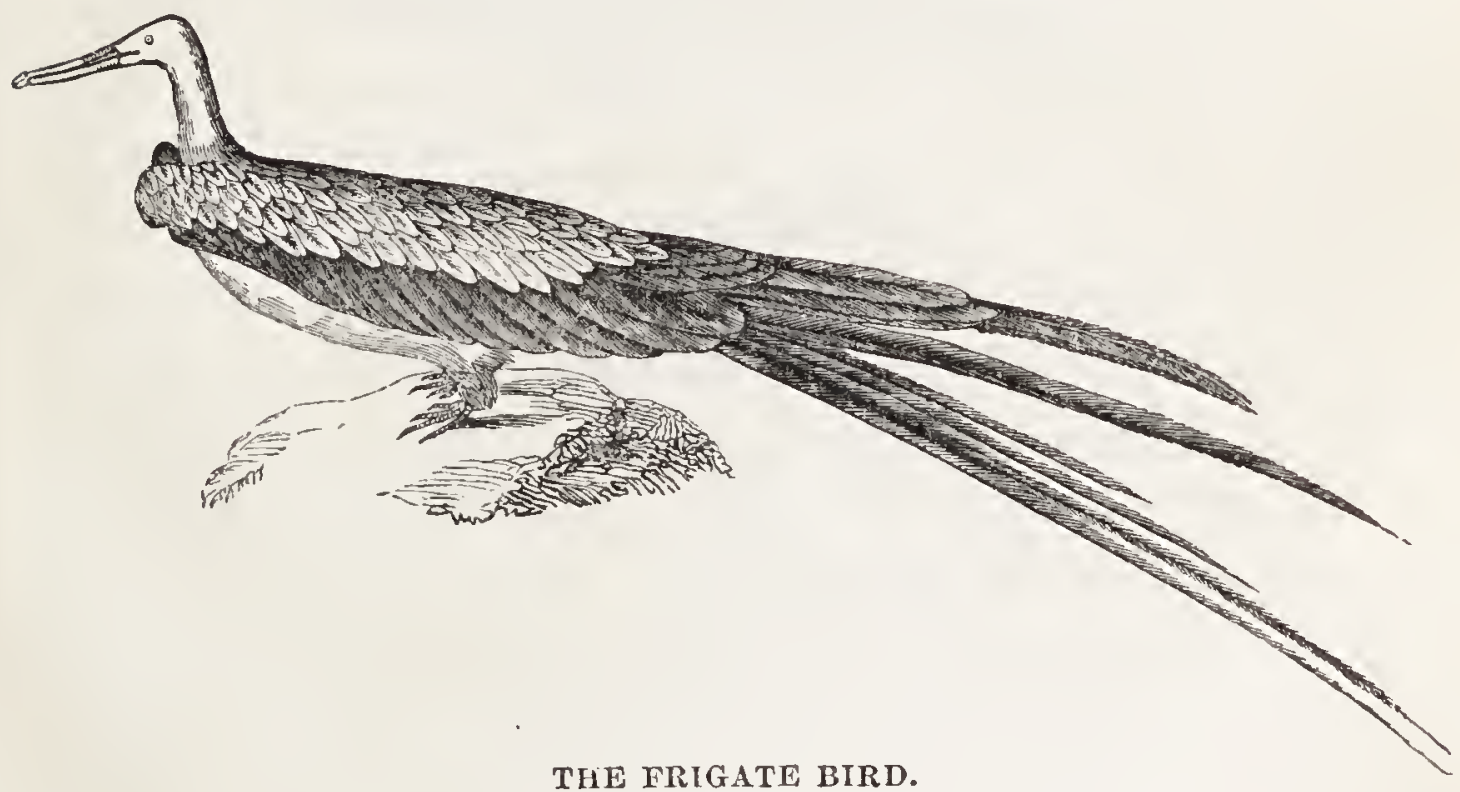

It is often met with 1200 miles from land, and yet is said to return every night to its solitary rock-nest. Still, Quoy and Gaymard assert (Voyage de l'Uranie), that this bird is rarely found far from the coast; and when it is so, it is probable that there is an unknown rock somewhere in the vicinity.

Large flocks of Frigate Birds brood on the Paumotu group, where Captain Wilkes found several trees covered with their nests. When the old birds flew away, they swelled up their 
red crops to the size of a child's head, so that they seemed to carry a bladder of blood on their necks.

The Gannet (Sula Bassana) has derived its name from the locality where it is most frequently found. The Bass, a high steep mass of rock, at the mouth of the Forth, resembles, in the distance, a mound of chalk, from the multitude of Gannets and other sea birds sitting on it, although it is really formed of red porphyry.* The waves only allow a landing at one spot, and the entrance to this natural fortress is protected by a locked door. The owner, at the time when Mr. Fleischer visited the Bass, had let it to another man for a yearly rental of thirty-five pounds. No eggs are collected upon it, and there is a fine of five pounds for killing an old bird; only the young birds are exposed to danger. The sport begins on August 1st; they are taken with the hands or knocked over with sticks, and then sold in Edinboro' Market, at half-a-crown a-head. The gannet is also found frequently at Ailsa, on the coast of Arran, and the island of St. Kilda; but nowhere else in Europe.

Though this bird is regarded as very foolish, it does not display that quality when fishing. Flying quickly over the water, so soon as it sees a fish swimming below, it falls perpendicularly upon it, head first, and never misses its mark. As it is compelled to drop a little before it can fly, it is obliged to build its nest on high walls, or on the sides of precipices.

The family of the Gulls (Laridce), to which the gulls, terus, petrels and albatrosses belong, is widely extended over the globe. All birds of this genus are endowed with great power

* The trap of the Bass has been described by Boué as a clinkstone; by Mr. James Nieol, in his "Guide to the Geology of Seotland," as a fine granular greenstone or clinkstone. Mr. Hugh Miller deseribes it as "an intermediate hybrid species."- The Bass Rock, p. 102. 
of flight, and are distinguished by the easy grace of their movements, as they float through the air with a scarcely perceptible motion of the wings. Their form is handsome and well-proportioned; some bearing a likeness to the swallow, others to the pigeon. Nearly all undergo remarkable changes of plumage at various ages, and some even change the colour

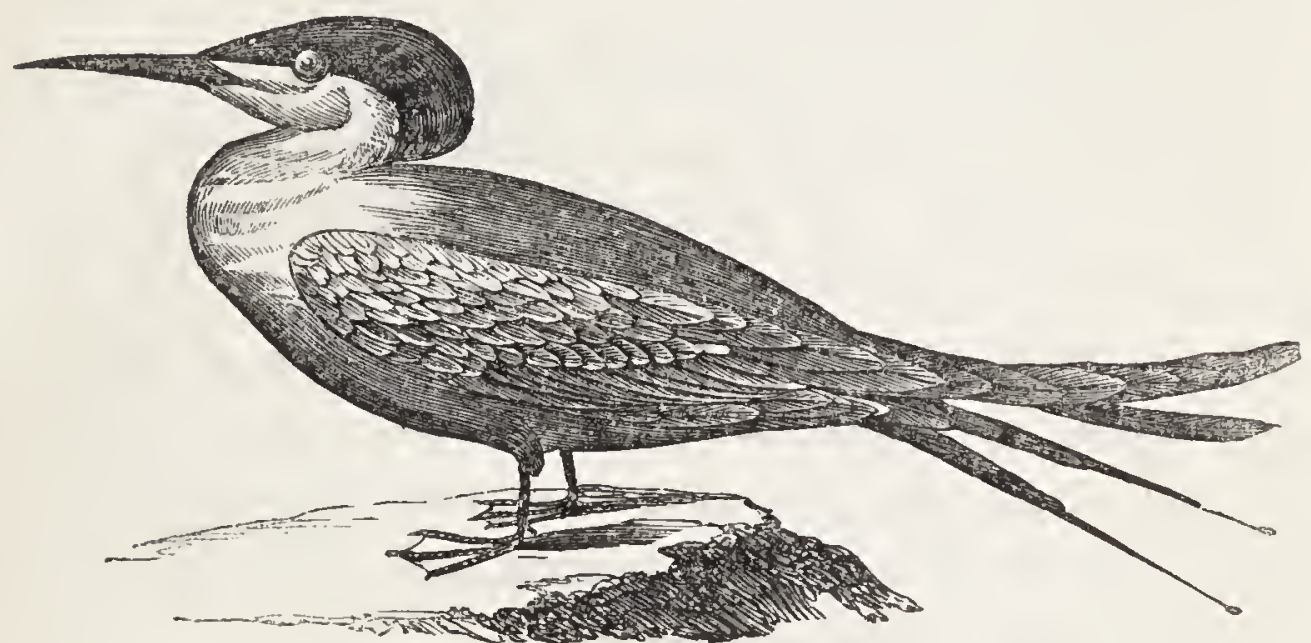

SEA GULI.

of their dress annually, the feathers growing darker at the period of incubation. This change of colour, according to some naturalists, takes place without moulting, for the headfeathers, originally whity brown, gradually change to dark brown or black. Unhappily, the conduct of these birds does not harmonize with their fair exterior, for they are all remarkable for piratical propensities and insatiable voracity.

The cry of the gull is very peculiar, a medley of laughing and crying; and when it is mingled with the hoarse murmur of the waves on some desolate island, it seems to suit the character of the scene.

It is delightful to watch the manœuvres of the gulls at the mouths of the larger rivers, and notice how busily they are 
engaged in picking up the animal substances which the efflux or reflux carries to the sea. At times they descend to the crest of the rising wave; and then they skim the surface of the water, or dive, with closed wings, immediately to re-appear, holding a fish in the beak.

Many varieties of gulls inhabit the northern coasts, and breed in many localities.

The Kittywake, or Three-toed Gull (Larus Tridactylus), one of the most common sea-birds in Greenland, Iceland, the Ferroes, and the Scottish islands, builds its sea-weed nest on the highest and most inaccessible crags.

At Grimsoë, according to Faber (Prodromus of Icelandic Ornithology), they brood in such numbers, that their flocks obscure the sun when they rise, cover the islands when they settle, deafen the ear when they croak, and render the green rocks almost white where they breed.

On the celebrated Bird Mount, at the northern extremity of Sylt, the Silver Gull plays a very prominent part. Its size, equal to that of a crow, though with much longer wings, its pleasant shape, the purest, most dazzling white, as the prominent colour on the back, gently tinging off into light ash blue; the black velvet ends of the wings, with snow-white points; the cheerful yellow eyes, the bright ochre beak, with its coral spots - all this together produces a most charming picture.

On the same promontory, but at some distance, the Blackbacked Gulls (Larus Canus) breed; they are much smaller than the former, and their unspotted beaks are weaker; and it is the same with the Kent and Caspian Gulls. How strange it is, that here, as at other gathering-places, each sea-bird occupies a distinct district; while only the Auks brood to. 
gether. What can induce the birds to assemble in such large masses, and then keep aloof from each other?

The proprietor of the gull-preserve at Sylt, nets two hundred dollars a-year. 50,000 eggs, which are larger than those of the turkey, are collected annually, packed in moss, and exported to the continent. Three men are engaged in collecting them, from $S$ a.m., to the afternoon, and receive, in payment, all the small eggs, which also amount to 20,000 .

But though the gulls collect in large numbers at Sylt, they have chosen the small island of Norder Oog as their headquarters. The breeding colony of Kent Terns (Sterna Cantiaca) is estimated at no less than a million, so that, when the birds are sitting, the island, at the distance of five miles, looks like a white strip on the water; but when they rise, they form a dense revolving cloud. The eggs at some places are so close together, that it is impossible to walk without crushing them; and the birds would hardly find room, did they not sit with their heads toward the sea, as is the habit with all varieties of the sea-swallow. It is extraordinary how each bird recognizes its own eggs - it might be thought impossible, did not instinct effect impossibilities. The noise is indescribable, for even through the night, they keep up a constant, and often very animated, chattering. Anyone who approaches them by day, is soon surrounded by the chattering mob; and these birds, generally so shy, will fly so close to his head, as often to strike him with their wings.

On Novaia Zemlia's ice-girt shores, on the summit of isolated pinnacles, and suffering the presence of no other bird, broods the great Grey Gull (Larus Glaucus), which the Dutch whalers, either through respect or the want of it, have christened the "Burgomaster." This haughty bird, which is twenty- 
eight inches in length, and measures five feet with outstretched wings, seems to feel himself lord of the creation, and no other bird dares to dispute with it the daintiest morsels, when it settles on a dead whale.

Yet it yields to superior strength when it comes across the Black and white Gull (Larus Marinus). This bird deprives the Burgomaster of his prey, attacks ailing birds, drags the Auk's eggs into its nest, and sucks them, and also collects, on the strand, the hopping sea-insects and molluscs.

In the Predatory Gulls (Lestris Parisiticus: L. catarrhactes), the weight of the body is so small, in comparison with the mass of plumage, that they are but poor divers. Unable to fish for themselves, they are compelled to plunder their weaker relatives. Hardly do they see that a three-toed, or silver gull, has made a good haul, than they immediately give chase, and compel it to disgorge the just swallowed fish. This they contrive to catch very carefully, ere it reaches the water.

Although the sea-swallows and gulls are distinguished for a rapid flight and are often seen far from land, only the Stormbirds (Procellarice) and Albatrosses deserve to be called oceanbirds, as they remain almost constantly far at sea, and only visit solitary islands and coasts at the brooding season.

The Storm-birds, which are also called Peter's-birds or Petrels, are found over the entire ocean; but the petrels that inhabit the northern arctic, vary from those at the south pole, and between the two extremities of the earth are other varieties, which never quit tropical waters.

The Icy Petrel, or Fulmar (Procellaria Glacialis) is found in the northern seas. So soon as the whaler has left the Shetland Islands behind him, the ship is accompanied by these whitishgrey birds, which are ever vigilant, and dart, like an arrow, 
on anything thrown overboard. This bird, so helpless on land, flies in the fiercest storm against the wind. They are often seen collected by thousands on a dead whale, and they appear with the same wondrous rapidity as the condors and vultures on the Peruvian plateaus, when prey is scented.

If a stone be thrown among them, the nearest rise, and the terror extends, until the whole flock rises with hoarse croaking. The greediness of this stupid bird, which will not be driven off, however much it may be struck at with the boathook, affords sailors rare sport. If prey is scarce, the Fulmar will follow the diving whale, as if speculating upon its future fate; and thus shows the experienced whaler, by its peculiar fluttering flight, where he may seek his prey.

The Arctic Petrel ( $P$. gelida) does not appear to approach so near the pole as the Fulmar. It is rare in Iceland, and large quantities breed in Newfoundland. The same is the case with the Mother Carey's Chicken ( $P$. anglorum), which is repeatedly met with on the Ferroes and the Shetland Islands. The tropical Petrels are the least known. They do not appear to collect in flocks, and rarely follow vessels. The first Pintados ( $P$. capensis) are seen about $45^{\circ}$ south latitude, and begin to grow scarce after crossing the sixtieth parallel. The Giant Petrel ( $P$. gigantea) extends as far as the southern icebanks, where the Antarctic ( $P$. antarctica) and Snowy Petrels ( $P$. nivea) make their first appearance. They never quit this harsh climate, and are often seen by hundreds on the drift ice.

Thus nature has appointed settled limits for petrels as for whales and every swimming and flying creature, and allotted the varieties among the deserts of the waters. Who can tell us the mysterious law which gives each its home? Who can 
reveal to us the invisible barriers which they dare not go beyond?

The Dwarf Petrel (P.Pelagica) seems to be everywhere visible; but three varieties have already been distinguished in this species. It is about the size of a swallow, and is not unlike this bird in appearance and flight. Although the smallest of all sea-birds, it defies the most furious hurricane, and skims boldly along the surface of the waves. Like all of the family, it is nearly always at sea; but, at the season of incubation, it seeks solitary rocks and coasts, where it lays its single egg in cavities and fissures.

The food of the Petrels agrees but slightly with their external beauty; for they are the crows of the ocean, and live on all the dead animal substances that float on the surface. All the Petrels have the remarkable faculty of spitting from their nostrils an evil-smelling oil when they are frightened.

The Albatross (Diomedea exulans) is the real king of the water, the picture of a hero, who, beneath the most violent storms of evil fortune, preserves the unvarying equanimity of a brave heart.

Proudly and nobly the Albatross floats in its element, and defies the fury of the storm, not touching the water with even the extremities of its wings. It rises with the waves, and sinks calmly again into the abyss.

"It is marvellous," M. de Tessan says (Expedition de la Venus), "how the Albatrosses deride the fury of the unchained elements, and fly against the most violent wind. Our sailors said, that they were as easy as if they were at home. And really this word is characteristic; for you hardly saw one move in a quarter of an hour, though they hover in the air. 
When quite close, the eye can detect a slight tremulous motion of the hinder plumage, and the ear notices the sound of feathers ruffling gently. Probably the cause of this long snaring can be found in the vibratory movement of the wings, which resembles that of the fish's tail."

The Albatross exceeds" the Swan in size, weighs twelve to twenty-eight pounds, and, with out-stretched wings, measures ten to fifteen feet.

For weeks and months it will follow a ship; but Harvey (Sea-Side Book) fancies that the duration of its flight has been over-estimated. Although, like the Gull and Sea-swallow, it is not a diver, it swims with great ease; and in spite of the enormous width of its wings, it can rise into the air very quickly again. It is true, that a captured Albatross cannot raise itself from the narrow space of the deck; whence it has been precipitately concluded, that the birds which follow the ship have spent the whole time in the air. But no one can have observed the wandering Albatross closely, without seeing that it frequently sits on the water. It lives on animal substances that float on the surface of the sea; and though it at times sweeps up its food while flying, it just as frequently folds its wings, and swims round like a Gull. If it desire to rise again, it takes a run, while flapping the water with its wings, till it has attained the proper impulse, and found a wave of sufficient height, from whose crest it springs, and begins anew its majestic flight across the world of waters. The Albatross is rarely seen in the north; it belongs especially to the southern hemisphere. A short-tailed variety (Diomedea brachyoma) is found frequently in the Kamtschatkan waters, but the wandering Albatross rarely crosses the thirtieth parallel of south- 
ern latitude, and is met with more frequently as higher latitudes are approached. Between $59^{\circ}$ and $60^{\circ}$ it was most frequently seen by Freycinet; and probably it knows no other southern barrier than that of the Polar ice. It flies through all the meridians of this enormous space; but the true stormy regions - Cape Horn and the Cape of Good Hope - are its favourite habitat.

All voyagers know that they are not far from the southern promontory of Africa when Albatrosses appear in large numbers. These birds are the vultures of the ocean; their crooked sharp-edged beak is better adapted to tear asunder a lifeless prey, than to catch the rapid fish. They scent a dead whale from an immense distance, and soon collect in large bodies round the corpse. In addition to this rather chance food, they devour crustaceans and pteropods; but, above all, cephalopods, which are very frequent in the open sea, and, as we have seen, support the gigantic Sperm Whales. Remnants of cephalopods are almost always found in their maw, but never any fish. The Auckland and Campbell Islands appear to be the favourite breeding-places of the Albatross. While Sir James Ross was anchoring off them in November, these birds were so busy breeding, that they were caught without any resistance. Their nest consists of a sand-heap, mixed with grass and dry leaves; it is eighteen inches in height, with a diameter of twenty-seven inches at the top, and six at the base. While breeding, the bird's snow-white breast surmounts the grasses, and betrays it from a long distance. If you attempt to drive it from its eggs, it offers a vigorous resistance, and gnashes its beak as if in defiance. Its greatest enemy is a wild gull (Lestris antarcticus), which is ever on the 
watch; and so soon as the bird leaves its nest, it flies down to it, and plunders it.

Though the Albatross flies quickly, thought traverses space even more rapidly, and transports us suddenly from the desert islands of the South Sea to another hemisphere. Hence we ask our reader, to whom we wish to offer a sketch of a republic of birds, to accompany us to St. Kilda, the outermost

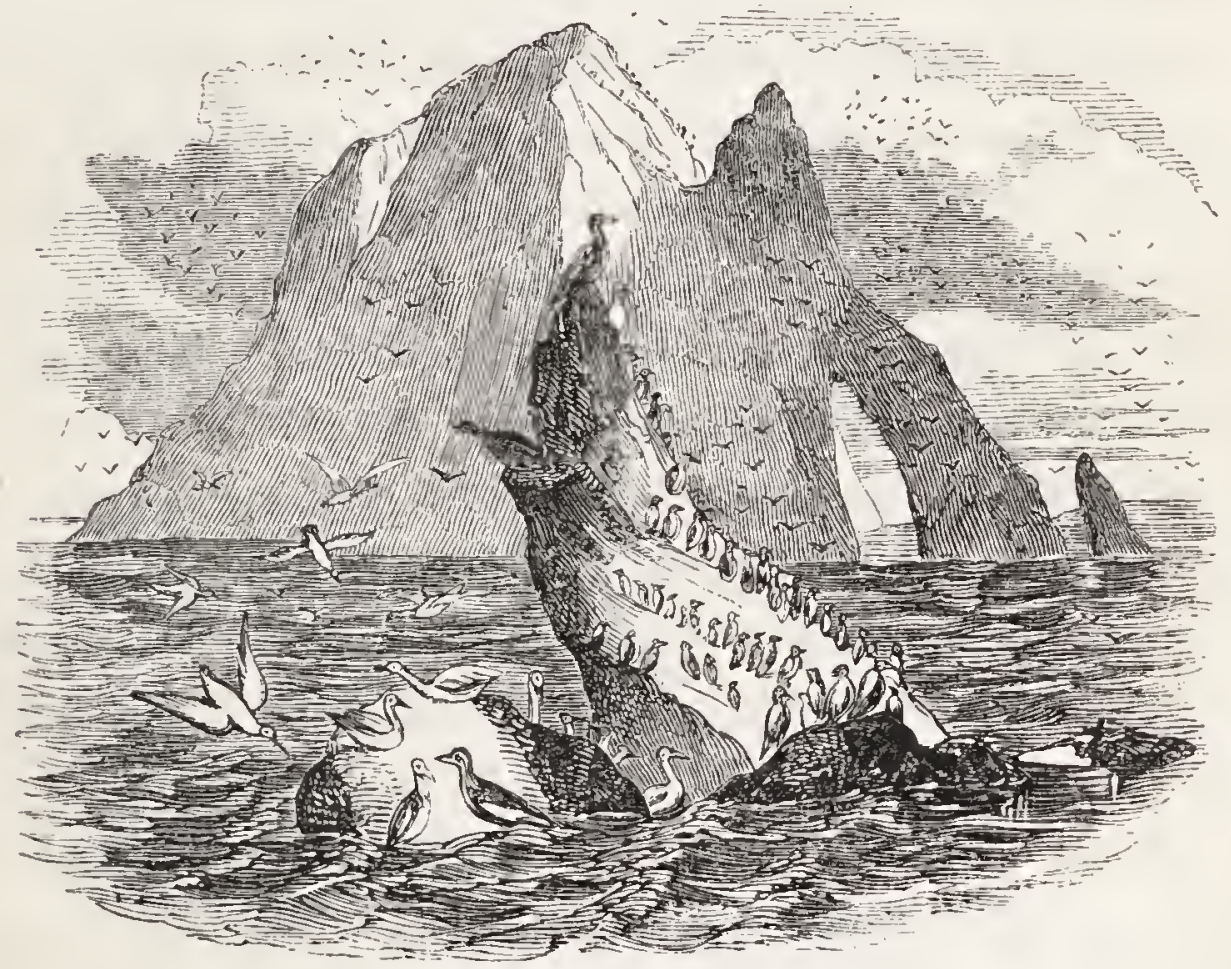

ST. KILDA.

of the Hebrides, where the magnificent rock-scenery will at once delight him. The small island, which is about five miles in circumference, rises almost perpendicularly from the lap of ocean, and forms, at its eastern end, which rises 1380 feet above the level of the sea, the highest promontory in the British isles. From the edge of this abyss, a prospect surpassing all description is obtained. At many spots, the rock 
is hidden by myriads of brooding sea-birds; the atmosphere is filled with their croaking flocks, and the water appears everywhere covered with them. Every high plateau is closely invested by Three-toed Gulls. Boobies and Guillemots, Fulmars and Puffins, have taken possession of all the grassy slopes; while close to the water's edge, in cavities excavated by the swell, groups of Cormorants stand, motionless and erect, like unclean spirits, guarding the entrance of a gloomy enchanted cave.

If a lump of stone be rolled from the summit into the sea a most remarkable tumult is produced. Perhaps the block kills a luckless Fulmar brooding on its nest; then it bounds with mighty leaps, and awakening the echoes, deeper and deeper into the abyss, here tearing deep furrows in the grassy slopes, there dashing against projecting points, and driving the startled birds in every direction. Their rising clouds indicate its dangerous path, till at length it disappears in the waves, carrying many a victim with it. Before long, however, the disturbed denizens return to their nests; and the tumult gradually subsides.

Several varieties of the Gull are found on St. Kilda; as Larus marinus, fuscus, canus, tridactylus. The latter is the most common, which, as we have mentioned, builds its nest on most inaccessible spots, and is not troubled by the islanders. If a colony of these Gulls be disturbed, they leave their nests in a body, and fly round the intruder in dense masses. The noise of their wings, with their loud cries, to which the deep notes of the Gannets, and the hoarse croaking of the larger Gulls are joined, produce a medley of sounds such as can be heard nowhere else. 
The Fulmar broods on St. Kilda in extraordinary numbers, and is to the natives by far the most valuable production of their island. It is found on the highest rocks, but only on those having grass growing on their sides. On being seized, it ejects a clear amber-coloured oil, which is regarded by the Islanders as a universal remedy in all external ailments, and especially in chronic rheumatism; it is also used to feed their lamps. The best is obtained from the old birds by surprising them at night, and squeezing their beaks. After this, they are permitted to eject a couple of spoonfuls of oil into the dried maw of a Gannett, which is employed as receiver.

The bird-catchers of St. Kilda frequently risk their lives in following the Fulmar. Two of them, provided with long ropes, proceed to the edge of a crag. One of them fastens the strongest cord under his arms, and holding the end of the other in his hand, is lowered from the rock. His companion stands a little distance from the edge, holding the rope which is fastened round his waist tightly with both hands, while he allows the signal end to slip away under his foot. So soon as the fowler reaches a slope covered with Fulmars, he collects his harvest: he picks up eggs and young, and kills the old birds with a short stick, or catches them with a noose fastened to the end of a switch. He then fastens the birds together, and seeks a new colony; till, at length, richly laden, he gives the signal to be pulled up.

The skill of these island cragsmen is astounding. The smallest surface is sufficient for them to stand on; and they crawl on hands and knees, when loaded with birds, along the narrowest ledges of rock. 'Their strength is so great, that if the fowler who has been let down makes a false step, and falls 
the whole length of the rope into the abyss, his comrade saves him and himself by his obstinate resistance. Such strength reminds us of the heroic age. But even more wonderful stories are told. One morning, a fowler went out alone. After fastening his cord round a rock, he let himself down till he reached the spot where he hoped to have a good day's work. By cleverly using his feet to swing himself from the crag, he managed to reach the spot, but neglected to fasten the rope round his body. While collecting the birds, it slipped from his hands, oscillated a few times, but at last hung motionless from six to eight feet from his hand. For a moment, the cragsman stood in mute horror, almost robbed of his senses by the sudden awfulness of his position. And it was, in truth, frightful: the rock above him was steep as a wall; the sea below was filled with jagged rocks; there was no chance that, at the depth he was, his voice could reach the ears of his fellow-men. There was only one thing left him: a frightful leap might enable him to seize the rope, and save himself. If he missed, death was certain; but better so than to die of starvation on the crag. He therefore formed a brave resolution, muttered a short fervent prayer, collected all his strength; and sprang into the vacuum. He lived to tell the deed; for he succeeded in clutching the rope, and returning to his family.

Enormous swarms of Gannets are also found on St. Kilda. This bird flies nearly every morning across to the other Hebrides, the nearest of which is about fifty miles, to fish in the bays. It is very silent in its brooding-place, from which it excludes all other birds. Not a single Gannet broods on Hirta, while Borreray is nearly entirely cuvered with them, 
as well as the adjacent rocks, Stack Ly and Stack Narmin. The latter appear from a distance to be covered with snow; a deception produced by the countless Gannets which lie on the rocks or fly around them. Twenty-two thousand of these birds are killed annually at St. Kilda, and an enormous number of their eggs collected, without any sign of a decrease in their number. It has been calculated, that this species alone devours close on 100,000,000 herrings annually.

Storm-birds, Kittiwakes, Puffins and Auks (Alca tordo), are also met with in large numbers on St. Kilda. If we now reflect that similar congregations of birds are found on all the coasts and on all the islands of Northern Europe - all more or less pursued by man - we learn to admire the endless abundance of nature, which has covered the naked rocks with such rich life. The enormous numbers of some aquatic birds is the more extraordinary, as many species - the Auks, Fulmars, Gannets and Puffins - only lay one egg which is often found in such a precarious position on the naked rock, that it is difficult to comprehend how incubation is possible. Sea Eagles, huge Falcons, predatory Gulls, suck the eggs, and carry off the young birds: the Lestris catarrhactes feeds its young entirely on young Auks, Gannets, and Fulmars: the larger fish, too, snap up many a bird: hundreds perish in the severe cold, and in arctic storms: many a brood is destroyed at one swoop by a spring-tide, which washes away the eggs and helpless young birds - and how many, too, does man kill!

Still their number and value for the household of the northern islanders and coast-dwellers remain unaltered. But - of far greater social value than all the oil and meat, all the 
feathers and eggs of the hyperborean republics, has guano or, more properly, huanu-become for Europe during the last fifteen years.

On nearly all the islands and the uninhabited promontories of the whole west coast of America, especially the intertropical, this priceless dung is found; but the most productive and celebrated spots are the Chincha Islands near Peru, about 100 miles to the south of Callao, where it forms enormous strata, fifty to sixty feet in depth.

The upper strata are of a greyish-brown colour; those deeper, rusty-brown. The guano becomes gradually closer and firmer as the diggers go down; a circumstance explained by the pressure of the upper strata. It is well-known to be composed of the dung of various sea-birds, among which Tschudi quotes Larus modestus, Rhynchops nigra, Plotus anhinga, Pelecanus thayus, Phalacrocorax, Gaimardii, and Albigula, but, above all, Sula variegata, as the most important guano manufacturers. Any one who has seen the enormous flocks of these birds, and knows not only their astonishing greediness, but also the facility with which they can appease their hunger in those seas, will not feel astonished at the size of the guanobeds, which have been produced by the uninterrupted accumulations of centuries.

The fresh guano is white (Guano blanco), and is considered by Peruvian farmers the best. It is collected on the Punta de Hormillas, on Jesus, Islay, Margarita Island, etc. So soon as preparations are made to remove the guano, the birds quit the neighbourhood. It has also been noticed, that since the increase of commerce and navigation, they have retired from those islands which are in the vicinity of ports. 
The Peruvians have known the use of guano for many centuries; and under the Incas it was regarded as a valuable branch of the national revenue. There was a penalty of death for killing the young birds on the guano islands. The entire distance between Arica and Chaucay, a distance of two hun. dred nautical miles, was exclusively manured with guano. Each island had its inspector, and was allotted to a distinct province. Under the Spanish rule, the land has lost much of its former productiveness; but during the last fifty years, the Haciendas in the Chaucay valley have consumed annually 25,000 to 30,000 bushels of guano, principally obtained from the Chincha Islands.

The way in which guano is employed in Peru to manure the maize-fields is as yet generally unknown, and may interest our readers. A few weeks before the corn shoots up, a small hole is dug close to the stalk; a pinch of guano is placed in it, and covered with earth. About twelve hours after, the field is inundated, and left so for several hours. A smaller quantity of the white guano is used, and the field watered for a longer pericd. The effect is incredibly rapid; and in a few days the plant attains double its former height. If the dose of manure be repeated, the crop is thrice as fine as that obtained from an unmanured field. The regular climate of a coast where it never rains, is the cause that the Peruvian guano produces a much sharper manure than that of Africa, as less of the salt has been destroyed or evaporated.

The use of guano in Western Europe has increased enormously. On the Iquique island, a layer, thirty feet thick, covered a space of 220,000 square feet: in twenty-seven years it was carried away. Many of the smaller islands have also 
been stripped quite bare. In 1854, 250,000 tons, and in the first three months of the next year, 80,000 tons, were dug up on the Chincha Islands; and the export at the present moment is not less than half a million. The Antwerp agent of the London house, Gibbs and Co., which has held a monopoly of the Chincha Islands for many years, receives alone 200 cargoes a year, and lives like a prince on the profits of the sale. The revenue of his principals is estimated at $\mathfrak{£ 1 0 0 , 0 0 0}$ a year. The digestive processes of the birds produce the Peruvian government larger sums than all the treasures of the silver mines at Cerro di Pasco; and its transport undoubtedly employs a larger mercantile fleet than that which, in the last century, kept up the communication between Spain and her colonies.

"The Chincha Islands," Castelnau says (Expedition dans les parties centrales de l'Amérique du Sud), "are quite desolate, and denuded of vegetation. Their granite formation is distinctly contrasted in colour with the thick guano layer which covers it, and looks like snow in the distance. The steep perpendicular coasts render a landing difficult, but facilitate taking in cargo; for the vessels anchor close to the quarries, and all that is necessary is to lower the guano through a long tube into the hold. The visitor need only compare the excavations (scarcely perceptible at a short distance off) with the enormous layers, to feel convinced of the inexhaustibility of the stock."

A couple of huts are erected on the island, where a few Peruvian officials and soldiers watch the lading of the ships amid the ammoniac effluvia. 


\section{CHAPTER IV.}

The extinct Sa urians.--Structure of Tortoises.-Their Sihape. -Mode of laying Eggs.-Melancholy Fate of the Young.Turtle-catching in Ascension Island. - Their Use among the Romans as a Recipe. - Tortoise-shell. - The great SeaSERPENT.

THERE was a time when Reptiles were the lords and masters of the sea. Then the ocean swarmed with gigantic Lizards, Ichthyosauri, and Plesiosauri, fifty and sixty

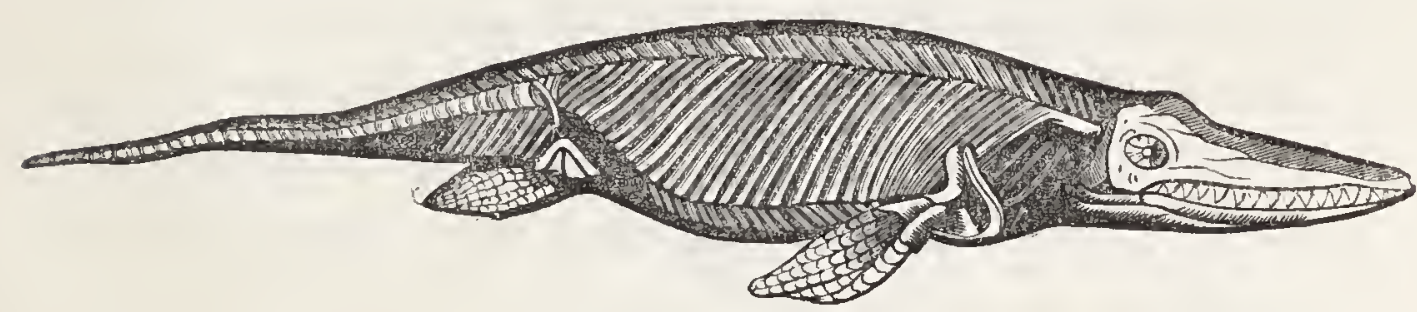

ICHTHYOSAURUS COMMUNIS.

feet long, the tyrants of the fishy tribes, who united to the speed of the Dolphin the voracity of the Crocodile. Had these monsters of the deep been gifted with human sense, they would, with human arrogance, have doubtless regarded their empire as eternal. For where, in the entire ocean, was the enemy who dared measure its strength with them? Did not all fly as sonn as they shewed themselves? And must not the productive sea for ever supply them the most abundant food? But, for all their strength and superiority, they 
have perished, and yielded to the force of all-devouring time.

During countless centuries, sea and air underwent a gradual change; the components and temperature of the elements no longer renained the same; another ocean and another atmosphere originated, in which these giant creatures could not exist. Thus, then, they were expunged from the book of life, and all traces of their former existence are restricted to a few petrified remains, which we gaze on with wonder in our museums, as the mighty ruins of a past-away creation.

The largest lizards of the present age - Crocodiles and Alligators - have yielded the supremacy of ocean to other animals, and retired into the rivers and morasses of the tropical zone: the sea no longer affords shelter to Saurians; Tortoises and Sea-serpents are the only reptiles it conceals in its lap. As a general rule, animals belonging to this class are the most repugnant of creatures, mere types of moral and physical ugliness; so that no one can think without a shudder of the cold slippery skin of a toad, or the stony glance of a snake.

The Tortoises, however, do not share the repugnance we entertain against the majority of their relatives - the Snakes, Lizards, and Batrachians - either because their harmlessness makes them liked, or perhaps because they are useful to man in many respects; while all other reptiles, with the exception of a few well-tasted lizards, and the cheerful frog, of whose croaking we must think gratefully, are either of no service to man, or even threaten his life through their poisonous teeth.

The structure of the tortoise offers many curious points. 
In a most extraordinary manner, the vertebræ, ribs, and breast-bone are so dilated, that they form a bony shell around the entire body of the animal.

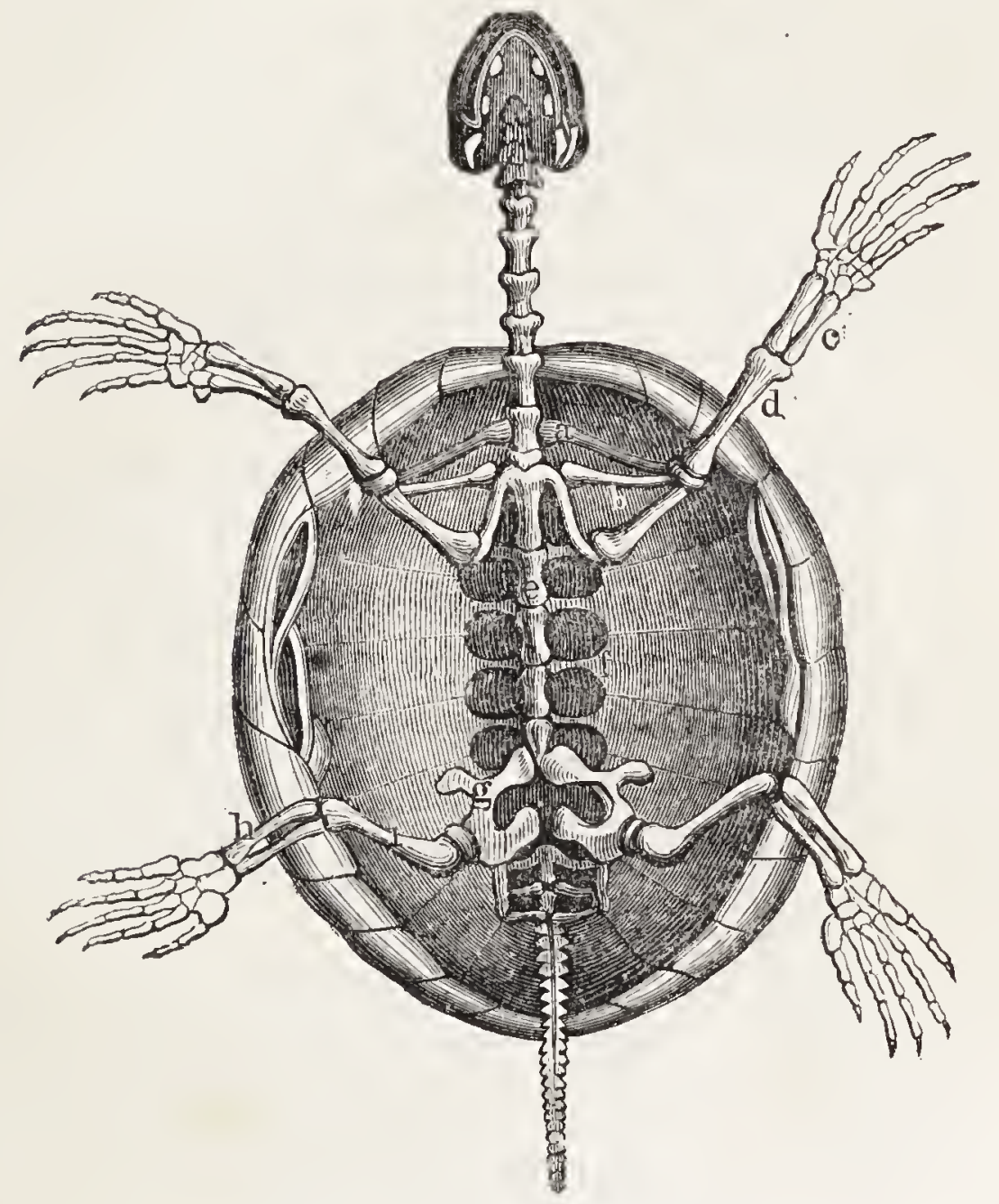

SKELETON OF A TURTLE.

$a$ Shoulder-blade. $b$ Collar-bone. $c$ Fore-arm. $d$ Humerus.

$e$ Dorsal Vertebræ. $f$ Ribs. $g$ Bones of the Pelvis. $h$ Tibia.

$$
i \text { Thigh-bone. }
$$

This species of harness is covered by the skin, which is, in its turn, covered by large scaly plates of tortoise-shell; while all the inuscles, etc., are contained in the internal cavity. The head, feet, and tail, alone emerge through openings between the upper and lower carapace; but, in the Land Tortoises, they cannot be entirely drawn in. 
This is the sole protection nature has afforded these animals against the attacks of their foes: they possess neither speed for flight, nor any weapon with which to defend themselves effectually. But so soon as a suspicious animal approaches them, they conceal themselves under their thick covering, and oppose to the attack the passive resistance of a coat of armour impenetrable by tooth or claw. The majority of the animals that pursue the Turtles have an insurmountable difficulty in turning them, as they usually attain a considerable weight, and they defend themselves by their size.

It might be assumed that this protection could only last a short time, as the animal must surely draw breath like every living creature, and hence be compelled to pop its head out sooner or later. Still, the watching enemy might lose its patience long before the Tortoise required to draw breath; for it is a cold-blooded animal, and can exist for a long period without fresh air - a circumstance which is of material value in defensive operations.

How comes it, though, that respiration, which produces warm blood in the mammals, should in this case make it cold? We think it right to give a short answer to the question, as it will doubtless interest many of our readers.

Without entering into any minute description of the heart of the mammals, we will remark, that it is composed of two parts (each of which, again, contains two divisions), the auricle and ventricle; and that the right-hand half, which receives and passes through the lungs venous blood, is entirely separated by a long partition wall from the left-hand half, which receives the arterial blood from the lungs, and distributes it through the entire body. In this way, the two sorts 
of blood are quite distinct; so that the venous blood flows unmingled into the lungs, where it is converted into arterial blood by the oxygen of the air. This metamorphosis, however, like most chemical processes, is combined with a development of heat, which is so considerable in the mammalia, that their internal temperature always, and under all circumstances, remains at from $37^{\circ}$ to $44^{\circ}$.

'The Tortoises also inhale oxygen, and some heat must be necessarily liberated by the process; still, with them, respiration is so retarded and limited, that their temperature never rises perceptibly above that of the surrounding atmosphere, and increases and decreases with it. This slower life is principally produced by the peculiar structure of the heart, which has only one auricle and ventricle, which constantly sends into the lungs mixed blood-half arterial, half venous - which necessarily produces a retardation of the life process. Further, the lungs of the tortoises are not designed to receive any large quantity of blood, as their cells are much larger than in the Mammalia, and thus offer a much smaller surface for contact with the atmosphere. Lastly, as the tortoises have immoveable ribs, their chest

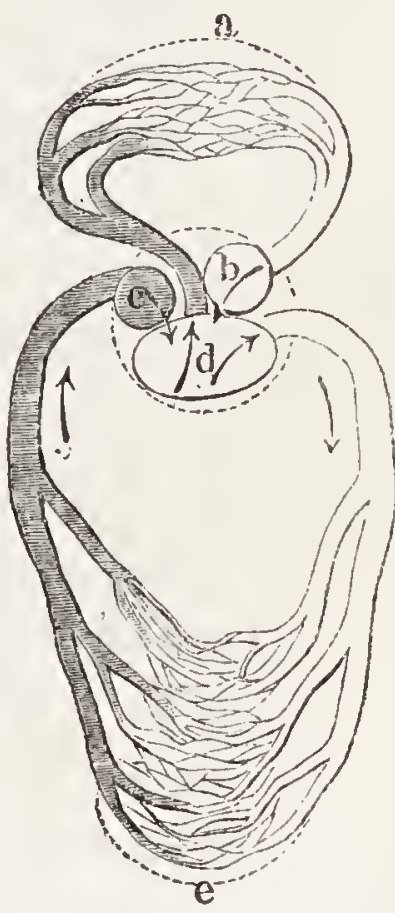

CIRCOLATION IN REPTILES.

a Pulmonary Circulation. $b$ Left auricle. $c$ Right auricle. $d$ Sole rentricle. $e$ General circulation. cannot be expanded to receive air, so that they are forced to swallow it, and pump it into the lungs, by contracting the 
muscles of the neck. We thus see how all works together to reduce the amount of oxygen required by the tortoises to a minimum, and to stamp on their nature the seal of coldbloodedness. Their whole formation harmonizes with this slow life; their dulled senses and want of intelligence, the sluggishness of their movements, and their power of starving for days, and inhaling no fresh air for a long time. They seem to pass a half-awake, miserable life, a species of dreamy existence; but in spite of the step-motherly way in which they appear to have been treated by Dame Nature, they cannot be considered unhappy; for, as in all other animals, there is a marvellous harmony between their structure and their wants, and where this exists pleasant feelings must prevail.

The Turtles, with which we deal here exclusively, are distinguished from the land-tortoises principally by their larger and longer fin-like feet, as well as by the considerable development of the tail, which serves them as a paddle. They have no teeth, but the horny upper mandible fits as closely on the lower as the lid on a snuff-box, so that it can crush shells as easily as it can separate the tough fibres of the seaweed. Turtles are found in all the warmer seas, though at times carried by currents into colder regions. Thus, in 1752, a turtle (Chelonia Midas viridis), six feet long, and weighing nine hundred pounds, was caught off Dieppe; and in 1778, a leather turtle (Sphargis Coricucea), off Languedoc. They even proceed further north; for in 1856, a specimen, weighing several hundred pounds, was stranded near Ostend. It will be seen, from these instances out of many, that the turtles may be reckoned among the more important denizens of the sea, although they 
do not attain, as Pliny tells us, such a size, that a single upper shell will serve as a roof or a hoat. They live almost entirely in the sea, some on shells, like the Carett Turtle, others on sea-grass, like the Testudo Midas, and only land during the warmest months, to lay their eggs. "We followed the monotonous sea-coast," Prince Maximilian of Neuwied says, in his capital "Tour in Brazil," "and our two soldiers - an Indian and a negro - stopped very frequently to dig turtle eggs out of the sand, which, boiled in the evening, supplied our supper. While busied in preparing for the meal, and collecting dry wood on the beach, we found, a short distance from our bivouac, a colossal turtle ( $T$. Midas), on the point of laying its eggs. Nothing could have been more grateful to the hungry company; and the animal seemed to have come on purpose. Our presence did not disturb it; we could touch it and lift it up, which required four men. While we were expressing our admiration loudly, it evinced no other sign of restlessness, than by puffing and working away with its finlike hind-feet, which threw up the earth with a regular movement. One of our soldiers laid himself on the ground by the side of the Turtle, put his hand in the hole, and threw out the eggs as fast as the animal laid them. About a hundred eggs were collected in this way in ten minutes. We then consulted, whether it would be advisable to enrich our collection with this animal; but it would have required an extra mule, so its life was spared. These colossal animals - Midas coriacea, caretta - lay their eggs in the hottest months in the uninhabited coast-range between the Riacho and the Mucuri: they land about twilight, and return to the sea two or three hours after sunset. A few hours later, we could not find the 
Turtle which had so abundantly supplied us; it had stopped up its hole, and the broad trail in the sand showed that it had crawled back to its element. The Midas generally lays ten to twelve dozen, and the soft-shelled eighteen to twenty dozen eggs at once."

On the desolate coast of Bantam (Java), a number of Turtles collect yearly for this purpose. They have frequently to crawl five hundred to a thousand feet over the beach, till they meet with softer and looser sand; and this journey, which is a long one for them, threatens them with many dangers. When Junghuhn traversed that desolate coast, he saw hundreds of Turtle skeletons lying about, many five feet long, and three feet broad and high; some bleached, and displaying smooth bones; others still partly filled with mouldering entrails; others, again, still fresh and bleeding. In the air, multitudes of birds of prey were circling. This is the spot where they are attacked by wild dogs (canis rutilans). The barking animals attack the poor Turtle in packs of from twenty to fifty at every available spot, gnawing its paws, head, and tail, and manage, by combining their strength, to turn it over. Then the dogs begin gnawing at either end, tear up the stomach-shell, and regale on the flesh and eggs. Sometimes, however, the Turtle escapes their fury, and reaches the sea, dragging the tugging dogs after it. Nor do they always devour their prey in peace. Sometimes it happens that the lord of the desert, the Royal Tiger, breaks out from the forest; he surveys the beach with sparkling eyes, then creeps up, and bounds with a hollow roar among the dogs, which fly in terror. Then the Tiger has a dainty meal, though he, too, is sometimes disturbed by man. Junghuhn's 
Javanese drove off a tiger during the night, after startling it by a musket-shot, and seized the still living Turtle, which six of them could scarcely carry. Thus, on this desolate, aweinspiring coast, wild dogs and tigers wage war with the denizens of the ocean.

The cold-blooded Turtle leaves the incubation of the eggs to the tropical sun, which generally performs the task in three weeks. The young, even of the largest variety, on crawling out of the egg, are not larger than half-a-crown, and of a white colour. Not being guarded or protected by any parental care, these poor beings seem only born to die at once. Their first instinctive course is to the element for which they are designed. They slowly drag themselves to the water; but the sea receives them with a rude embrace, and the waves often cast them mercilessly back on the coast. Here the large sea-birds, Storks and Herons, await them, against which they try to defend themselves bravely, or still larger birds of prey; and thus the life of many of them is puffed out on their first sight of the world. Still, if they succeed in reaching the sea, they fall a prey to the ravenous sharks. Hence there is good reason for the Turtle laying from four hundred to five hundred eggs in the spring: were it less prolific, the race must have died out long ago. The flesh of the Turtle is everywhere considered one of the greatest dainties. The king of the Monga Reva Islands, in the Pacific, preserves them in large tanks, formed of coral, for the requirements of his table; and the London alderman knows no greater delight than swallowing slowly a basin of Turtlesoup. Among the greatest blessings of steam, he counts the facility with which the fat Chelonix, and thousands of pines, 
are brought from the West Indies to the market of the world's metropolis.

No wonder that the sailor, tired of salt-pork and biscuit, hunts the Turtle on every coast of the tropical sea, where solitude, a flat sandy shore, and a favourable season, promise him a successful result.

We find a picturesque description of such a Turtle-chase on Ascension Island, in Bernardin de St. Pierre's "Voyage à l'île de France." "Fire-wood, a cauldron, with a large boatsail, were landed; the sailors sleeping on the last till night set in. About eight in the evening, the Turtles usually quit the water. Our people remained quiet, till one of them sprang up with the cry, 'A dead man! A dead man!' In truth, a small cross, planted in a mound of sand, announced that some one was sleeping his long sleep there. The sailor had, without noticing it, laid himself along the grass. Not one would remain near the corpse; so we sought a fresh bivouac, about a hundred paces from the spot.

- "The moon rose above the horizon, and illumined the solitude. Its light, which imparts fresh charms to a cheerful landscape, rendered the surrounding scenery only the more gloomy. We were encamped at the foot of a black hill, on the top of which was a large cross, erected by sailors. Before us was a plain covered with countless blocks of stone of a man's height, whose tops were whitened by guano, and glistened in the moonbeams. These pallid heads on black bodies, some of which were upright, others leaning, seemed to us like ghosts wandering over graves. The utmost silence prevailed on this deserted earth. Only from time to time the breakers of a wave on the beach was heard, or the cry of a Frigate Bird, which our presence had startled. We went to 
the great bay to wait for the Turtles. We lay stretched on our stomachs, in perfect silence; for the animal retires on hearing the slightest sound. At length we saw three Turtles emerge from the water, and slowly creep up the shore, like black masses. We ran up to the first; but our impatience was the cause of its slipping back into the sea, and escaping us. The second had crawled further inland, and could not retreat; and we laid it on its back. In this way we caught more than fifty Turtles, some of which weighed five hundred pounds. About ten the next morning, a boat came to carry our booty aboard. As the surf was high, it was obliged to lie at anchor some distance off, and drag the Turtles, by means of a rope fastened on shore, one after the other, into the boat. This task occupied the whole day; and in the evening the remaining Turtles were returned to the water. If they lie for any length of time on their backs, their eyes become bloodred, and start out from their heads. We found several on the shore, which had been left to perish in this way: a terrible piece of neglect, which the careless, thoughtless sailor is too often guilty of. Although Ascension Island is only a volcanic pile of slag, without any arab!e land or water, it occupies no useless place on the globe. Three months in the year, the Turtles visit it to lay their eggs in the sand; for they are animals which love solitude, and fly shores trodden by man. A ship, by anchoring twenty-four hours off the island, drives then for several days out of the bay; and, if a cannon is fired, some weeks elapse ere they return. We lived for nearly a month on the captured Turtles, and kept them alive the whole while by pouring fresh sea-water on them several times a day."

Turtles are also pursued by men in the sea. In the clear 
West Indian waters, where they may be seen grazing on the sea-meadows, divers descend to them, and pull them up to the surface. They are also sometimes speared, or surprised asleep, on the surface of the water.

The ancient Romans, who esteemed so many dishes highly for which we have no fancy now-a-days, seemed to have thought little of Turtle-meat, which these lords of the world might easily have procured from the Red Sea. We read, indeed, that Vitellius enjoyed dishes of pheasants' brains and nightingales' eggs; but not that he ever, like the Lord Mayor, regaled his guests with seven hundred tureens of turtle-soup. On the other hand, the Cheloniæ were much used by the Romans as remedies. The blood of the Turtle served to prevent the hair falling off, and against cerebral attacks. It was allowed to dry on the parts affected, and was then gently washed off. It was good for ear-ache, if mixed with woman's milk, and dropped in. It was excellent in epilepsy, when made into pills with wheat and barley-flower, wine and vinegar. Any man who cleaned his teeth thrice a day with turtle-blood, was as sure to escape toothache as the horses, donkeys, oxen and dogs, now baptised on St. Anthony's day at Rome, are to be protected from harm for the space of one year.

Turtle-gall made the eyes bright, reduced disfiguring scars, and cured the mumps and quinsey. When mixed with a cast snake-skin and vinegar, it was the remedy against a pustulent discharge from the ear. To render it still more efficacious, some physicians added ox-gall. We ridicule the ancients; but it is a question what the future will say of several of their remedies.

Tortoiseshell is principally obtained from the Carett Turtle (Testudo imbricuta), whose flesh is not held in great estimation; 
but which is covered with a thicker, stronger, and more transparent and finely-coloured carapace than any other member of the family.

" Carvilius Pollio," Pliny tells us, "an extravagant and inventive man in everything that concerned luxury, was the first who cut the scales of the Tortoise into plates, and adorned bedsteads and cupboards with them." The Romans obtained large quantities of this highly-esteemed article from Egypt.* In the reign of Augustus, many patricians had even the doors and pillars of their palaces covered with it. When Alexandria was taken by Julius Cæsar, such a quantity of tortoiseshell was found stored in the magazines, that the conqueror employed it as the chief ornament of his triumphal procession, as he did ivory after the African wars. The use of tortoiseshell to decorate furniture and houses has long been out of fashion; still it is largely used for the manufacture of snuff-boxes and combs. By softening it in boiling water, and then putting it under strong pressure, it can be easily made into every imaginable shape. When a large surface has to be covered, several pieces are fastened together. This is

* The tortoise-shell, so prized by the ancients, was obtained by the Egyptians, and after them by the Greeks, from the African shores of the Red Sea, more especially from the neighbourhood of Adule and Ptolemais. A writer in Smith's Dictionary of Greek and Roman Geography (art. Ptolemais), speaks by mistake of the true land-tortoise being met with at that place. It is a sea-tortoise which frequents the hot sandy shores. Arrian particularly notices it as being brought to Adule by the Ichthyophagi; and Bruce describes it as caught on low sandy islands, and its beanty to be so exquisite that it sells for its weight in gold to the Chincse. It is described by Agatharcides as covered with small lozenge-shaped plates, of the whiteness of the pearl-oyster. (See Geogr. Min., p. 40; Hudson, Periplus Mare Erythr., p. 17; and Vincent's Commerce of the Ancients, vol. ii., p. 116).-W.F. A. 
effected by planing the edge of the plates, then laying them on one another in a warm and softened state, and by the application of strong pressure forming them into one body. In this way, too, gold, silver, and other metals are united with tortoiseshell for various purposes.

The family of Reptiles, which is so largely scattered over the tropical forests and morasses, has but a few insignificant and innocent representatives in the sea. Voyagers only cursorily mention Hydras or Water-Snakes, two or three feet in length, which they noticed here; others in the tropical ocean. The Sea Serpent plays a much greater part in that misty region which is inhabited by Unicorns, Griffins, Krakens, Tailed-Men, and other more or less problematical creatures.

Olaus Magnus, it is true, talks of the great Sea Serpent as if it were a common apparition on the coast of Norway. It was said to live in the rocky clefts near Bergen; and set out at night, especially by moonlight, to play its tricks both on water and land; for it apparently enjoyed calves and pigs as much as crabs and mussels. It has a body all covered with scales; a mane, two feet in length, on its neck; and raises its head, in which two fiery eyes flash, like a mast above the water. It often attacks vessels, and carries off the men who happen to be on deck." This description may be taken as a sample of the falsehoods which are constantly being repeated. If such a monster lived on the Norwegian coast, a specimen of it would have been found somewhere? Countless vessels and fishing-boats navigate the Norwegian waters; and who has heard or read of a single authentic instance where a sailor or a boy was attacked by a Sea Serpent?

The Greenland missionary, Egide, certainly deserves more credit, who tells the following story in the journal of his 
voyages:- " On the 6th July, 1734, a very large and terrific sea-monster made its appearance, which raised itself to such a height above the water, that the head reached to the middle of the mast. It had a long sharp snout, very broad flabby fins, and blew out water like a whale. The body seemed to be covered with scales, and the skin was uneven and furrowed. After a while, the monster dived again, and threw up its snake-like tail, which was a good ship's length from the head." We feel a diffidence in disbelieving the reverend gentleman; but his lively fancy, already excited to an unusual degree by his apostolic mission, or his unpractised eye, may have deceived him, so that he ascribed an extraordinary shape and dimensions to some one of the larger sea-animals. If we add to this statement of Egide, the reports of a few other northern clergy - Pontoppidan, the missionary Nicholas Gramius, and the Hebridæan clergyman Maclean - some of whom state they saw the monster, while others write of it only from hearsay; as well as the narratives of some sailors, among others, of Captain M'Quhae, of H. M. ship "Dædalus," who declared that he saw a great Sea Serpent in $24^{\circ} 44^{\prime \prime}$ south latitude and $9^{\circ} 22^{\prime \prime}$ east longitude - all the testimony to the existence of this reptile is exhausted.

On the other hand, the incredulous remind us, that no bones of a Sea Serpent have ever been discovered, nor have they been found floating dead on the water, or stranded ashore. They consider, with Professor Owen, that these negative facts speak far more decisively against the existence of the Sea Serpent, than the positive assertions of a few witnesses do for it; and that it would be easier to collect far more printed attestations for the existence of ghosts than for the reality of the Sea Serpent. 


\section{CHAPTER V.}

General Remarks on Fish. - Organs of Motion: Tail, Fins, Natatory Bla uder. - Scales. - Beadty of Tropical Fish. Tiie Gills. - The Journeys of certain Fish on Land. - Weapons of Fishes. - The Sfa Wolf. - The White Shark. - The Saw Fish.-The Sword FisiI.--The Torpedo.-The Star-gazer. -Tine Angler.-Remark a die Capture of Flies.-The Chatodon Rostratus. - The Remora Euployed to Catch Fish. - Strange Weapons of Defence of some Fish. - The Tracinnus. - Tiie Stickle-Back. - The Doree. - The Flying Fish. - Numerous Enemies of the Fish. - How many Fish may there be? - The Herring. - Importance and History of time Herring Fishery. -The Pilchard.-The Sprat. - The Cod-fish.-The Sturgeon. -The Sterlet.-The Salmon.-The Tunny.- Louis XIII. and the Madrague.-The Mackarel.-The Bonita.-The Murana. - Tre Lamprey. - Flat.fisit, or Pleuronneta. - The Halibut. -Tine Turbot.-Tine Sole.-The Plaice.-The Sirate.-Enormous Increase of Fish. - Their Diseases. - Modes of telling TIIEIR AGE.

THE lap of ocean is full of mysteries: it contains an entire world, which the naturalist only knows superficially, and perhaps never will thoroughly investigate. It is comparatively an easy task to observe the habits of land animals, and accurately determine their specific varieties; but the element in which fish live removes them from human sight, and, in many cases, presents insurmountable difficulties to their accurate and continued investigation. Since the time of 
Pliny, who only catalogued seventy-four varieties, the number of species known to us has considerably increased. The ancients, who were only acquainted with the Mediterranean, and a small portion of the ocean, had no idea of the countless finny races which inhabit the tropical and arctic waters; but although later inquirers have already described and drawn eight thousand different sorts of fish, there cannot be the least doubt that, in the fathomless depths of ocean, as well as in the immense seas rarely visited by the European navigator, many an unnamed fish swims about. How little, too, do we know of the special habits of the sea-fish already known to us; of the relations existing between them and the other marine creatures; of the laws which regulate their peculiar existence? There is a grand mystery even attaching to the herring, a fish we all know so well; for the question whence it comes, and whither it goes, still remains unanswered.

If the entire economy of the piscine world was laid open before us, the magnificent picture would certainly give us fresh cause to admire the omniscience of the Creator; but that which is already revealed to us, suffices to convince us that the same harmony which presides over the structure and external relations of the birds and mammalia, also prevails among the fish; and that these creatures are admirably formed for the peculiar element in which they move and have their being.

If we, in the first place, regard their external appearance, we find the majority of them formed on one fundamental plan: tapering towards the extremities, and swelling in the centre - a form which gives them the power of cutting through the waters rapidly. This peculiar shape, which 
nature has given fishes, man seeks to imitate in the construction of his ships; but in spite of all his skill, and the aid of sails and steam-power, their motion is extremely slow and clumsy, when compared with the velocity of fish. The arrow starting from the bow does not traverse the air at greater speed than the Salmon or Tunny shoots through the water. It has been calculated, that the former, in one hour, covers a span of 86,000 feet; a speed which would enable it to make a circuit of the globe in a few weeks, if it thought fit to rival a Cook or a Magelhaens.

Whales and Dolphins beat the water downwards; fish, on the other hand, move by side-twists, and by extensions of the vertebra. In some varieties (Eel, murcena, etc.), the whole body is flexible; but the majority of fish strike the water

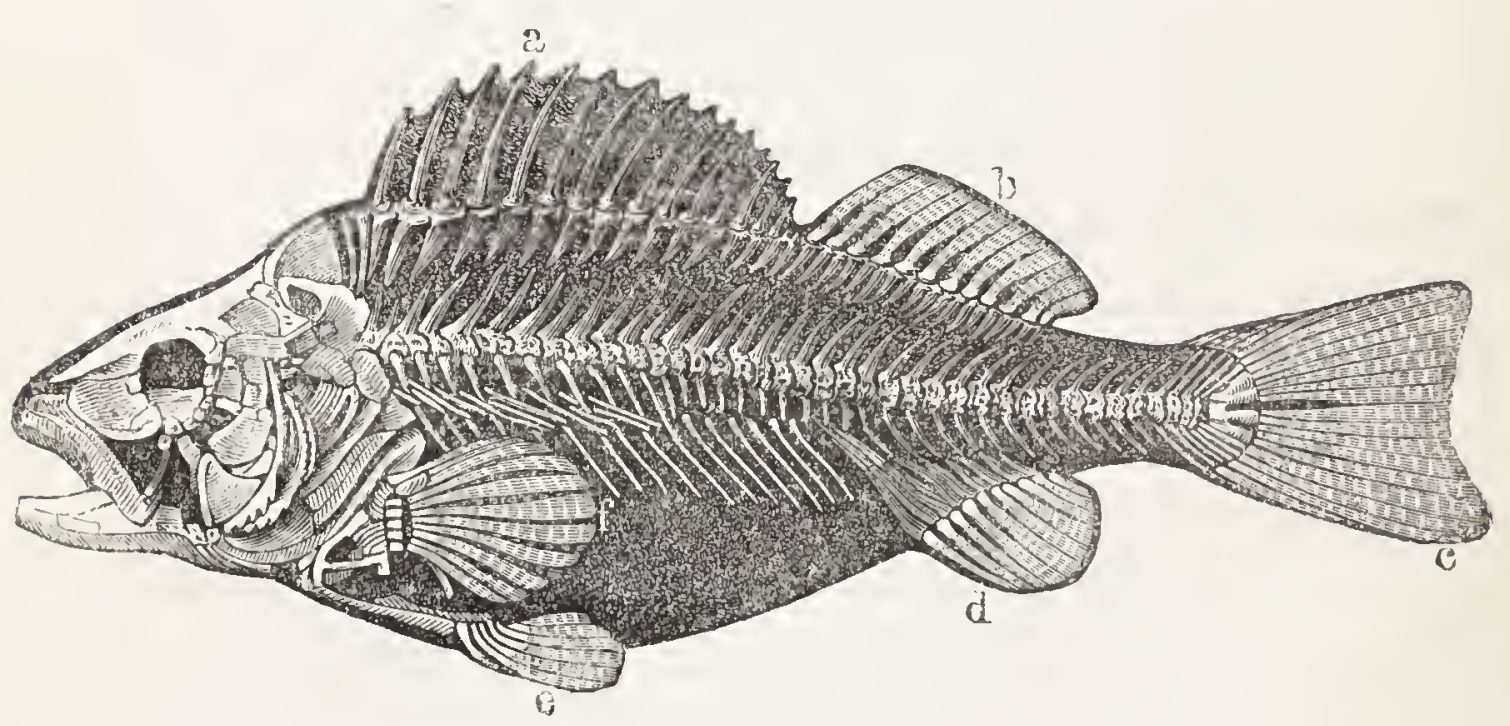

SKELITON OF A FISIT.

a. First dorsal fin. $b$ Second dorsal fin. $c$ Caural or tail fin. $d$ Anal fin. $e$ Ventral or abdominal fin. $f$ Pcctoral fin.

with the tail, on the right and left in turn, and the resistance of the fluid impels them onwards. Hence we find the chief 
strength of the fish concentrated in the muscles that bend the back-bone; and these are generally so developed, that they constitute the greater portion of the body.

The fins, affixed perpendicularly on the central line of the fish, serve to increase the extension of the paddling uppersurface, and the rapidity of the movement; while the side, pectoral, and ventral-fins, though helping but slightly in the forward movement, exercise a far greater influence on the direction of the movement, while keeping the body in equilibrium. By the aid of these organs, the fish can turn and twist in the water as it pleases; and it is remarkable to watch how, by extending or drawing in one or the other fin, it traverses the water in every direction.

Not less wonderful is it, to notice how perfectly the size and nature of the fins correspond to the wants of the different varieties of fish. Those which traverse large tracks of water have broad strong fins, with which they can contend against powerful waves and currents: on the other hand, these organs are weaker and smaller in the inhabitants of rivers and shallow water; and they are soft in those fish which rarely expose themselves to the fury of the wind, or remain in deep water, where the fiercest blast does not affect them.

By the aid of the natatory bladder, situated in the stomach, fishes can increase or lessen the specific gravity of their body at will, and thus rise or sink in the fluid element. When they compress this remarkable gasometer, and expel the air contained by means of the ventral muscles, the cir. cumference of the body is reduced; they sink, and can swim with ease on the bottom of the sea. When they wish to rise again, they need only suspend the muscular contraction, and 
the bladder swells again; the body, increasing in circuit, becomes lighter, and rises without any exertion to higher regions. Thus, we see the same physical law employed by the fish which is the basis of our aerostation. The same natural force enables the inhabitants of the ocean to rise and sink in their denser element, which raises the aeronaut in the air, and brings him to earth again. In those fish which are designed to live on the bed of the sea, or conceal themselves in slime - such as rays, flat-fish, eels, etc. - the natatory bladder is entirely absent, or is reduced to a very small size; for nature, in her wise economy, gives no animal any useless organ. Lastly, the slimy matter, which the skin of nearly all fish secretes, facilitates their motion: so admirably is everything calculated in them for increased speed.

Before we pass to a consideration of the internal structure of fish, we must bestow a moment on their external covering. In some few varieties, the skin is nearly naked, or merely covered by a simple scarf-skin; but, in the majority, it is protected by scales, which, in some cases, are rough and uneven, or form thick tubercles; but are usually thin plates, which lie on each other like the tiles on our roofs, and are bedded in the furrows of the skin like our nails. Above this scaly garb, nature has expanded the lustre of beauty in many European varieties; but she displays her utmost splendour in the torrid zone. If, among the equatorial birds, some portions of the plumage sparkle like the most splendid jewels, the tropical fish display every colour of the rainbow; and no pencil can reproduce the beauty of the shading, and the magnificent gold and silver reflections of certain families, whose every movement in the crystalline waters offers fresh charms to the delighted eye. 
The most beautiful fish appear to dwell among the coralreefs. Where the zoophytes (which also glisten with every colour of the prism) build their submarine palaces, live the brilliant Chetodons, the glistening Balistæ, and the azure Glyphysodontes.

The atmospheric oxygen is as necessary for the existence of fish as for that of the land-animals; but as they do not inhale it directly, but have to draw it from a denser element, which contains, at the most, only one thirty-fifth part of atmospheric air, their respiratory organs are necessarily formed differently from those of the mammals, birds, and reptiles.

Hence, gills take the place of lungs, which, in all bony fish, and the sturgeon among the cartilaginous fish, are constructed in the following way.

At the back part of the mouth are generally five fissured openings, separated from each other by four bone-arches, and opening into what is called the gill-cavity, which forms a space between the side of the mouth and the gill-flaps, which shut in the entire apparatus on the outside.

In this cavity are the gills, tender, cross-folded membranes, intersected by countless blood-vessels, one end being attached to the bone-arches, and the other free.

In breathing, the fresh air-impregnated water received into the mouth and swallowed, passes through the orifices into the gill-cavity, and flows out again through the flap, which opens and shuts alternately with the mouth.

While, then, in our respiration, the air must follow the same course in and out, the water always passes through the gill-apparatus in the same direction, from front to rear; 
which, for many reasons, must be allowed to be an admirable arrangement.

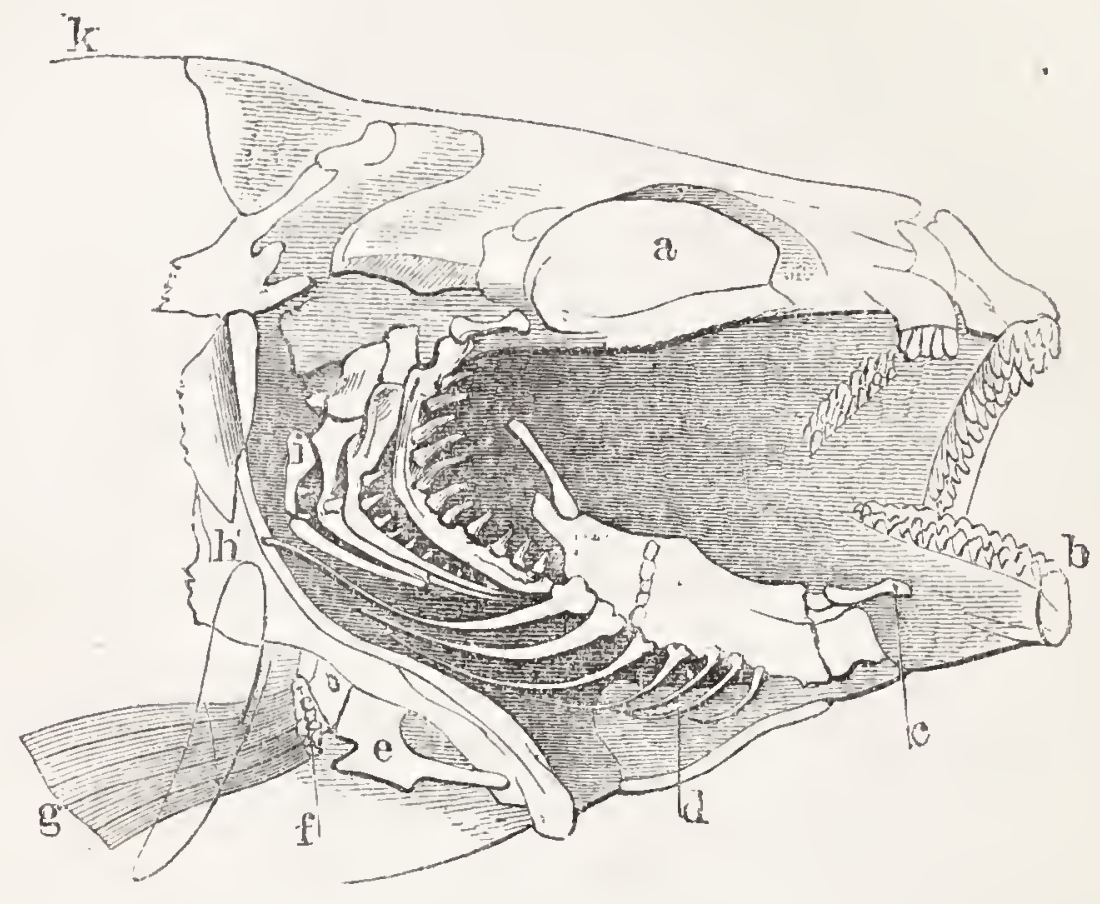

HEAD OF A FISII.

$a$ Orbit of the eye. $b$ Lower jaw. $c$ Hyoid bone. $d$ Laminæ, or rays, of the gill. $e$ Arm-bone. $f$ Small bones of the hand. $g$ Pectoral fin. $h$ Clavicle. $i$ Arches of the gills. $h$ Cranium.

If, for instance, the inhaled or swallowed water had to be expelled through the mouth again, it is evident that every respiration would impart to the fish a retrograde movement, and thus oppose the swimming motion which carries the fish onwards. But, as the water in the respiratory process always flows in a direction from front to rear, the fish is not only spared an unnecessary outlay of strength, but is even assisted in its progress.

We can see, too, how easily the tender gills could be thrown into disorder, if the water had to perform a retrograde movement through the mouth. 
In one variety of the cartilaginous fish, the Selacians (Sharks, Rays), and the Cyclostomes (Lampreys), the formation of the gills differs from that we have described.

The crevices do not open into a gill-cavity covered by an external flap, but directly into the water. The gills are not free, but attached to the external edge; though, in this variety, the water flows equally from front to back.

Although the gills are enclosed in a confined space, if laid out, they would cover a space of many square feet. Hence we see, how countless are the folds and ramifications with which the small respiratory apparatus touches the stream of water that flows through it, and abstracts the oxygen, and how wondrously nature has effected her purpose with the greatest economy of space. Breathing is a process of combustion; and this must necessarily proceed very slowly in an element which contains so small a quantity of oxygen. The scanty respiration, therefore, required an equally slow circulation of the blood. The heart consists of two chambers, thus corresponding with the right half of our heart; as it serves exclusively to drive the venous blood into the gills, where the fluid is converted into arterial blood, and whence, without requiring to be accelerated, as in us, by the influence of a powerful pulsa-

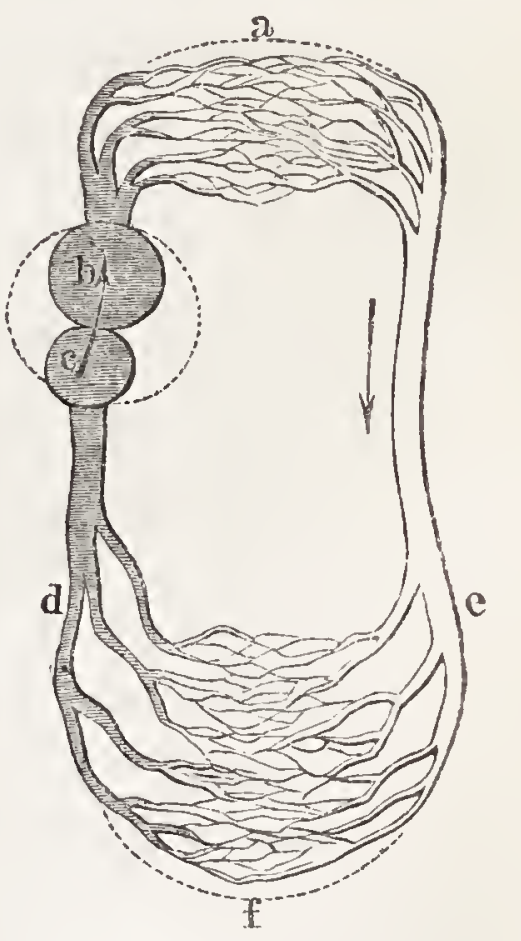

CIRCULATION IN FISHES.

$a$ Bronchial circulation. $b$ Ventricle of the heart. $c$ Auricle. $d$ Vcins. $e$ Arteries. $f$ General circulation. 
tion, it flows direct into the arteries, which are designed to spread it over the whole body. We see that, under such circumstances, very cold blood would be produced; just as it is impossible to keep up a lively fire in a stove which has only a slight draught.

It may appear curious, that when fish are taken out of the water, they do not die of an excessive dose of oxygen, but of want of breath. Their tender gills contract in the atmosphere; the blood can no longer flow through their countless fine veins; and, by being rapidly dessicated in the air, they soon entirely lose the power of breathing. Hence it is, that those fish whose gill-flap has a large opening, die most speedily in the air, while those whose gills are connected with a labyrinth of cells, in which a small stock of water is stored, which keeps the gills damp in the air, live much longer in the unwonted element.

By the help of such a damping apparatus, which they possess in the most perfect form, the climbing fish (Anabas) can live for days out of the water, and even clamber up the stems of trees some distance from the shore to capture insects. The chief varieties of the Anabas inhabit East India, China, and the Moluccas.

The Hassar (Doras costata), a South American fish, makes rather long journeys on land; and will go on the whole night through in search of fresh water, when the pond in which it has hitherto lived dries up. The shelly plates which cover the body, and the hard ventral fins, enable it to perform such a tour. It can even live for several hours in the hottest sunshine. The Indians, who often fill baskets with these emigrants (for the flesh is very dainty), assert quite correctly, 
that the Hassar takes a stock of water with it for the journey.

If it finds all the ponds dried up, it beds itself in the soft slimy soil, and subsides into a state of asphyxia, until the rainy season arouses it again.

But even more than through its migrations, is this remarkable fish distinguished by its maternal affection, only found in this instance among fish. Sir Richard Schomburgk, in his "Travels in British Guiana," tells us, that not only does the Hassar form a perfect nest for its spawn of all sorts of fibres among the aquatic plants, but it watches with the most active maternal care till the young brood slip out. The nest is a real work of art, like that of the Magpie. In April, the Hassar begins forming the nest, until it resembles a hollow globe flattened at the poles, the upper one of which reaches the surface of the water. An orifice, fitted to the size of the mother, opens into the interior. The maternal anxiety of the Hassar is, however, shamefully perverted to its destruction. A small basket is held before the hole, which may be easily found. The nest is then gently tapped, and the Hassar rushes furiously into the basket with bristling spines, which inflict a tolerably severe wound.

The Black Goby (Gobius niger) also prepares a nest for its spawn. It inhabits the slimy bottom of the Venetian lagunes, digs passages in the clay soil, and spends the greatest part of the year in them, secure from cold, storms, and foes. In the spring it goes to the weed-grown edges of the lagunes, and digs a dwelling, not so deep, but more spacious, which is matted with the rough roots of the Zostera, on which the female can lay her eggs. The architect watches the entrance 
of its house, holding its sharp-toothed mouth towards the enemy. The females soon arrive, and deposit their sparn.

We find similar care in the Stickleback, which the celebrated ichthyologist, M. Coste, frequently observed when building its nest. After the little fish has collected the materials, it heaps sand upon them, fastens the walls together with mud, and then prepares an opening. Afterwards it becomes the brave and indefatigable defender of the eggs, driving away all other Sticklebacks that approach its nest with snout and spines. If the enemy be too powerful, it has recourse to stratagem: it shoots hurriedly forward, pretending to be busily engaged in pursuit of something, and often succeeds in diverting the attention of its pursuers from the nest.

The existence of the finny race is an eternal warfare, a constant killing and being killed. Darting through the water, they menace with destruction every weaker being that meets them, or hurry to escape a similar fate. Many of them, in addition to their speed and strength, are provided with the most fearful offensive weapons. Thus, the Sea Wolf (Anarchicas lupas) has no less than six rows of teeth in each jaw, with which it crushes crabs and mussels, swallowing them, shell and all. If the monster is captured, it snaps at all around with blind fury. Schönfeld asserts, that it leaves the marks of its teeth on a ship's anchor; and Steller was present when a Sea Wolf, captured on the coast of Kamtschatka, seized a sword raised to kill it, and snapped it as if it had been of glass. The fishermen, who fear its bite, knock out its front teeth as soon as possible. It is often from four to seven feet in length. It usually keeps in deep water; but it 
draws nearer the coasts in spring, to deposit its spawn among the marine plants.

Even more terrible, through its size and strength, is the White Shark (Squalus carcharias, Carcharias vulgaris, Cuvier), whose jaws are also supplied with six rows of sharp-pointed teeth, which it can raise or lower at pleasure. This tyrant of the

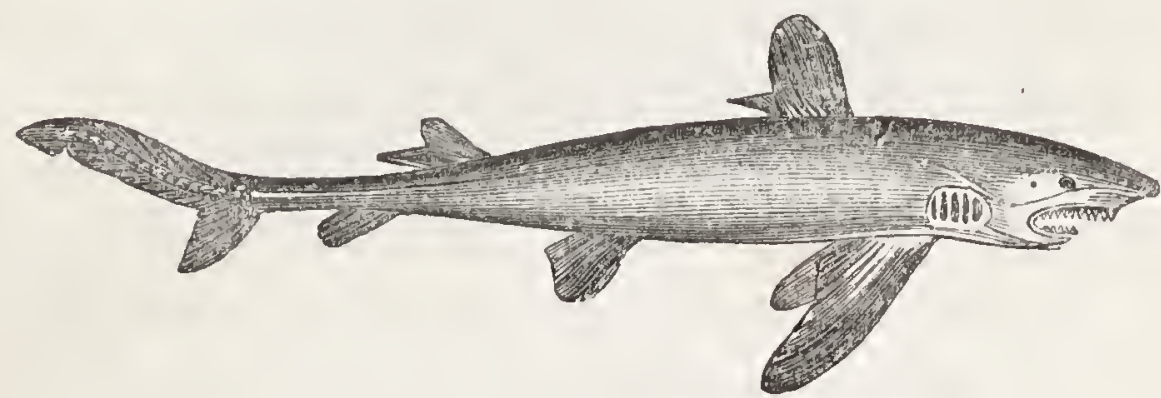

THE WHITE SHARIK.

sea grows to a length of thirty feet. The strength of its tail is so great, that even a young shark, only six feet long, can break a man's leg with a single blow.

No animal is more odious to sailors than the White Shark, which has swallowed so many an unhappy wretch in the tropical waters. If the yellow fever be raging on board a ship, the sight of the accompanying sharks augments the general despondency. They warn the observer, that the moment may not be far off when his body, sunk in the sea, will find a living grave in the stomach of these voracious monsters.

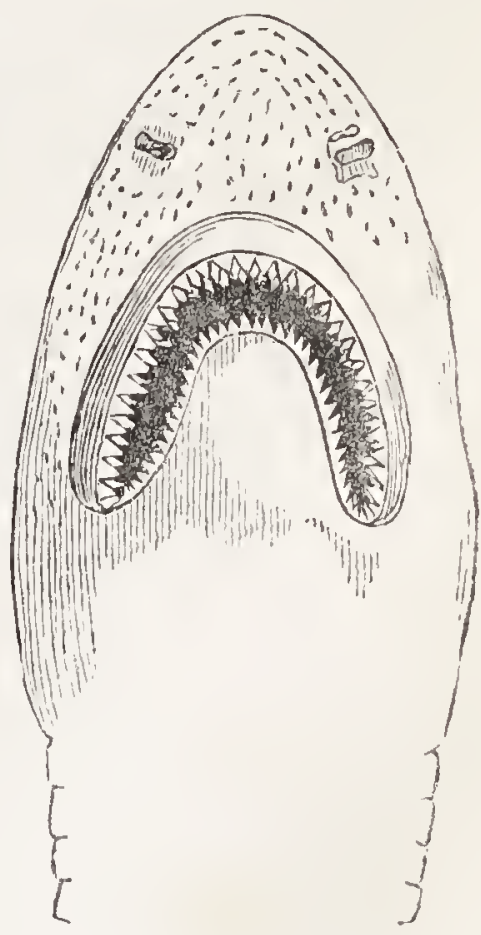

Fortunately for the lovers of a moбtil of white simark. reviving bath on the European coasts, a Squalus carcharias very 
rarely enters our temperate zone. The north has, it is true, its Sharks, too; but they are generally of a gentle disposition, like the Great Shark (Squalus maximus, Selache maximus, Cuvier), which feeds on sea-weed and Medusæ: while, on the other hand, the Spotted Shark, or Sea Cat (Scyllium catulus, Cuvier), in spite of its voracity, is too small to injure men.

The Saw-fish (Squalus pristis, Pristis antiquorum, Latham), and the Sword-fish (Xiphias gladius), which are fifteen feet long, are provided with specially fearful weapons. The snout of the former is elongated into a broad flat blade, armed with large teeth on the edges: in the latter, an equally powerful sword grows out of the upper jaw. The keel of an East Indiaman was once bored by a twenty-foot Xyphias so violently, that the sword went in up to the root, and the fish was killed by the force of the blow. The beam, with the weapon in it, is preserved in the British Museum, and affords an idea of the enormous strength of the leviathan of ocean.

While the majority of fish depend on their physical strength

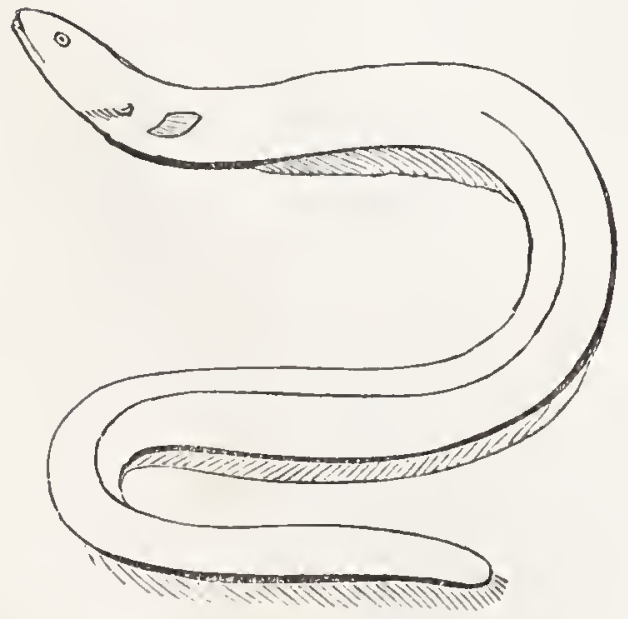

TIE ELECTRIC EEL. or speed for attack and defence, some of them are endowed with more mysterious weapons, and stun their victims or enemies by electric shocks. The stroke of the Torpedo (Raja torpedo, Torpedo vulgaris, Dumeril), is not so powerful as that of the Gymnotus electricus, which, as Humboldt has so charmingly described in his "Views of $\mathrm{Na}$ ture," kills horses; still, it can paralyse a man's arm. The 
Torpedos are principally met with in the Mediterranean, where they swim in forty fathoms of water. Other varieties are the Electric Shad of the Nile and Senegal, called by the Arabs "Raasch," or "'The Lightning," and the Electric Tetrodon of the tropical seas.

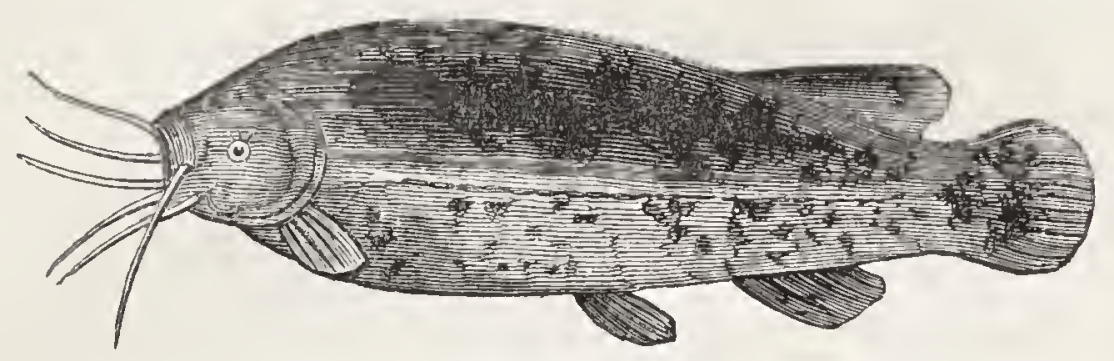

THE STARGAZER.

Other fishes, to which nature has denied all means of offence, try to capture their prey by stratagem. Hidden in the slime, the Stargazer (Uranoscopus scaber) only allows its head to emerge, in which the eyes are very close together, and moves the long tentacles on its upper lip backwards and forwards in the water. In this manner it deceives the small fish or crustaceans, which regard these organs as worms, and soon teaches them the difference.

The Angler, or Sea Devil (Lophius piscatorius), also called Fishing-frog, a slow swimmer - and would fare badly if it depended on the satisfaction of its hunger through its velocity - lies in ambush in a similar way, beneath the weeds or in the mud, and attracts numerous victims by allowing its feelers to play in the water.

Even the large European Shad (Silurus glanis), a fish which attains a length of ten to fifteen feet, and weighs three hundred pounds, does not despise feeding itself by similar snares. Like a true Lazzarone, it lies in the mud with its mouth half open, fishing with its long beard-hairs. 
No fish, however, catches its prey in a more remarkable manner, than the Archer (Toxotes jaculator). This small fish, only six to eight inches long, whose mouth is elongated into a cylindrical snout, inhabits the East Indian rivers, and lives principally on fies and other small winged-insects. On seeing one of these on any branch overhanging the water, it approaches with the utmost caution, till it comes exactly under it. It then shoots out a drop of water with such accuracy and force, that it rarely misses the insect, even if it should be five or six feet above it. In Batavia, Europeans and Chinese keep this fish in vessels of salt-water, over which they place insects on twigs, to enjoy the fun. But what do the poor flies say to it? The Javanese Squirt-fish (Choctodon rostratus) catches its prey in a similar fashion.

If all the other fish go hunting on their own account, the Indian Remora (Echineis Remora) has to thank its remarkable head, for the rare distinction of being employed by man to catch fish.

In Columbus' time, the coast population of Cuba and Jamaica employed this fish, which is from two to three feet long, for the purpose of catching Turtle, by fastening a long cord of cocoa-fibre round its tail, and then pulling it up again with its prey. By the aid of the Remora, they were enabled to raise Turtle weighing several hundred weight from the depths; for "it would sooner be cut to pieces," Columbus tells us, "than give up its prey."

We learn from Dampier and Commerson, that this stratagem is much employed on the eastern coast of Africa, at Cape Natal and Mozambique, as well as on the island of Madagascar. "Among nations which have no connexion 
with each other, knowledge of the habits of animals, and the same necessity, produce similar devices" (Humboldt, "Views of Nature").

We remark, parenthetically, that many fabulous stories have been told of the small "Ship-holder," a sucking-fish often met with in the Mediterranean. It derives its name from the supposed possession of the power to stop a ship's course; and as this extraordinary physical power was assumed to have an equally powerful moral influence, it was asserted that, by eating this fish, the most ardent love could be suppressed and subdued. If a culprit, or a man who had a cause for trial, desired to gain time for any purpose, and could succeed in giving the judge a piece of sucking-fish, he might be sure that the verdict would be long delayed.

The majority of fish save themselves by their rapid flight; but nature has specially favoured some varieties, and given them very peculiar means of defence. Thus, the dorsal fin of the Peter's-thumb, or Dragon Weever, (Trachinus draco), a small silvery fish, which is found in large numbers both in the Mediterranean and the Baltic, is provided with sharp spines, which effectually guard it against being swallowed. The stabs it gives are very painful, though it does not appear that the thorns contain any poisonous matter, as the fishermen assert.

At any rate, it is not by any means so dangerous as the round-headed Thornback, or Clip Bayre of the Brazilian rivers, which, with its long thorns, stabs an incautious person so terribly, that he is often deprived of his senses; and the inflammation lasts three weeks. The Blood-letter and Doctor (Acanthurus chirurgus and coruleus) are nearly related. In both, the tail is provided with a moveable, sharp, and lancet- 
like spine. We might imagine the Doctor, thus equipped, to be secure against any attack; but Catesby saw a Barracouta snap off its tail and swallow it, and then dispose of the rest of the body.

We might quote a long list of thorn-backed fishes, but will content ourselves with mentioning the poor little Stickleback (Gasterosteus aculeatus), which, though avoided by the larger fish, leads a life much embittered by worms. "Nihil est ab omni parte beatum!" as Horace tells us.

The Cropper (Tetraodon) and the Hedgehog-fish (Diadon) possess the faculty of blowing out their bodies at pleasure; in which operation the small thorns with which they are covered stand out in such a way that they frighten back the enemy.

The Flying-fish, as is well-known, are provided with such long pectoral fins, that, when they leap out of the water to escape their foes, they can fly a good hundred yards. They often rise fifteen to twenty feet above the surface of the water, and now and then fall on the deck of a passing ship. According to some observers, they can alter their course in the air; according to others, they follow the direction in which they started. The advantage they obtain from their winged fins is, however, only apparent; for while with them they escape the Bonitas, Dorados, and Dolphins, they fall a prey to the Gulls and Frigate-birds, which pounce on them ere they can return to the protection of the water. They are frequently seen by thousands, springing up in every direction, and thus afford some amusement to the voyager in tropical seas.

The Flying-fish (Exocetus Volitans) of the West Indian waters is frequently led by the warm temperature of the 
gulph stream into higher latitudes; and Pennant quotes instances of its having been seen even on the British coast.

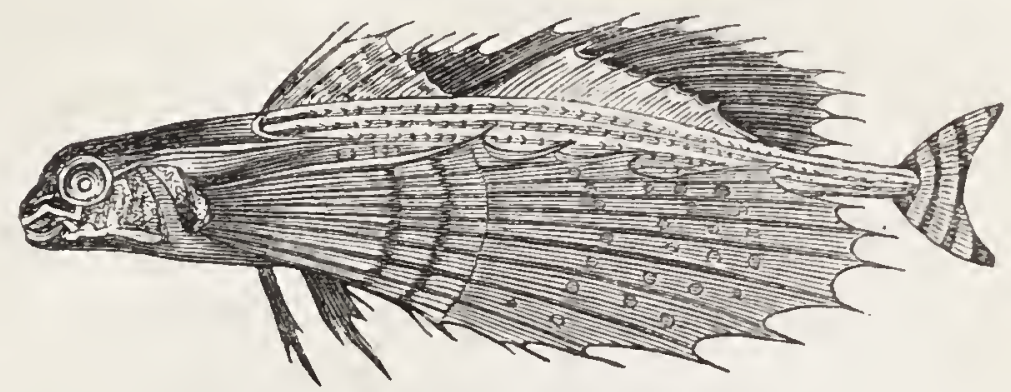

THE FLYING GURNARD.

The Flying Gurnard (Trigla Volitans; Dactylopterus volitans, Lacep.) of the Mediterranean and Atlantic, also rises above the water by the aid of its pectoral fins, which almost equal the body in length. It does not fly high, but a considerable distance; and thus frequently escapes from the pursuing Doiphin.

Neither quadrupeds nor birds are subject to such persecution as the fish, which have their irreconcileable enemies in every class of the animal kingdom. Countless molluscs and zoophytes feed on their eggs, or devour their young fry; myriads of sea-birds wait for them on the coasts, or snap them up out at sea; seals and ice-bears chase them; man spreads desolation among them, with line, net, and harpoon. It would be a difficult task to approximate even to the number of fish spread over the entire globe; but when we reflect that, in the British isles alone, according to a moderate estimate, more than a million men live by catching fish, and then cast a glance at the enormous extent of the coasts that skirt the ocean, we may assert, without any exaggeration, that at least the thirteenth part of the human race supports itself by the capture of the finny population of the sea. When we reflect, too, that fish is not only the staple food of the majority of the 
dwellers on the coast, but also in what quantities it is sent far and wide, eitler fresh, dried, salted, smoked, or pickled, we can convince ourselves that the enormous expanse of ocean only apparently limits the habitableness of the coast; for how many thousand square miles of the most fertile soil would be needed to produce so much food as the waters supply. Nor must we forget that the treasures of ocean are still most imperfectly worked; that the more the earth is covered with railways, a larger market for the produce of the fisheries will be opened up; that this trade, according to the opinion of the best judges, is carried on in a very rude and imperfect way; that, in a word, the sea, without being in the slightest degree exhausted, could give us twentyfold as much as it now does. "Alma Parens," the ancients christened the firm corn and grass-producing, cattle-nourishing earth; but with how much greater right does the sea deserve this appellation, which, without being ploughed and sown, offers its gifts in such abundance! Countless, indeed, are the varieties of fish which man employs for his nourishment; for nearly all supply a food as healthy as it is dainty: but the family of Clupeæ, or Herrings, is before all in its value to man.

What other product of the ocean can be compared in social value with the common Herring (Clupea harengus), which pours its treasures so lavishly on every coast of North Western Europe. This most valuable of all fish appears in shoals extending for miles, often pressed so close together that a spear stands upright in the living ground when thrown among them, and sends its countless legions into all the fiords, lochs, gulphs, coves, and bays, from Norway to Ireland, and from the Orkneys to Normandy. Countless marine birds thin their ranks during the summer; enormous armies of dolphins, 
seals, codfish, haddocks and sharks, devour them by millions, and yet their capture supports entire peoples.

When the time for their appearance draws on, the herring boats set out from every northern port, equipped with enormous nets, often 1,200 feet in length. The yarn of which they are made is so thick that it sinks with its own weight, and does not require to have stones fastened to the bottom; for it has been found that the Herring is more easily caught in a loosely hanging net. The upper end is kept floating on the water by means of empty barrels, and the whole is fastened to the boat by long cords. The Herrings are principally caught at night, and to prevent any collision, or perhaps to attract the fish, each boat has one or two lights. Off Yarmouth bank, where several thousand boats are often fishing at one time, these ever crossing lights produce a fairy-like scene. The meshes of the net are accurately calculated to the size of the Herring, just wide enough to let the head through to the gill flap, but not the pectoral fins. Thus the poor fish entangles itself in the large perpendicular wall which human craft has placed before it, and as it can neither advance nor retreat, it remains hanging till the fishermau pulls the net in again. In this manner such enormous quantities are sometimes captured, that we hardly dare to quote their numbers, though Cuvier and Valenciennes are our authorities. A Dieppe fisherman caught in one night 280,000 herrings, and threw an equal number back into the sea. At times large boats have been compelled to cut away their nets; for they almost pulled them down by their weight

The oldest document relating to the Herring Fishery dates from the year 709, and is found in the Chronicles of the Monastery of Evesham; while the first French documents 
only go back to 1030 . Under William the Conqueror, Yarmouth was already celebrated for its rich Herring Fishery; and Nieupoort, Dunkirk and Brill, carried it on upon a large scale for centuries; till William Beukelings, of Bieroliet, who died in 1449, discovered or introduced a better mode of packing the fish in layers in barrels, instead of salting them in irregular loose heaps, through which the best fish were lost. It is a question whether Solon or Lycurgus benefited their country more than this simple fisherman did his: for the pickle-herring* played a great part in converting a small unknown people into a powerful nation.

In 1603, the value of the Herrings exported from Holland was $£ 1,936,000$; in 1615 , their capture employed 2,000 busses, with 37,000 men. Three years later, we find the United Provinces sending 3,000 herring busses to sea; 9,000 vessels served to carry the fish to other countries, and the entire trade employed close on 200,000 persons. At that time Holland supplied the whole world with Herrings; and we may safely say, that this little fish was the most effective ally of the Dutch in casting off the Spanish yoke; for it supplied them abundantly with money, the principal material of war. If Charles V. could have foreseen that Beukeling's invention would cost his son and successor so dearly, he would hardly have shared a herring over the fisherman's grave with his sister, the Queen of Hungary, or emptied a glass of wine to his memory!

But every thing human is liable to change; and thus, toward the middle of the seventeenth century, the Dutch Herring Fishery sank, through a succession of unlucky cir* Our word, "pickle," is evidently derived from the illustrious Beukelings. 
cumstances. Cromwell gave it the first blow by his Navigation Acts; Blake, the second, by his victories. In 1703, a French squadron destroyed the greater part of the busses. The rivalry of the Swedes, and, at a later date, the English blockade during Napoleon's rule, completed the ruin of this once so enormous trade.

In 1814, the Dutch herring fishers made another weak attempt to revive it with 106 boats, which had only increased to 128 in 1823. The whole produce of the last-named year was 468,000 florins, entailing a loss of 200,000 florins. What a falling off was there! In 1833, not a single buss left a Dutch port; and only $49 \mathrm{fly}$ boats (little vessels of small tonnage) pursued the Herring fishery. Still, the period of the deepest ruin appears now to have ceased. So long ago as 1836, 117 busses were equipped for the great summer fishing; and the winter fishing in the Zuyder See, is continually growing more important.

In the second half of the last century, when the Herrings had begun to be unfaithful to the Dutch, they seemed to have a special delight in being caught by the Swedes and pickled; so that in 1781, the town of Gothenburg alone exported 136,649 barrels of Herrings, each containing 1,200 fish. A few years later, however, the Herring shoals began to grow so irregular in those parts, that, in 1799, their export was entirely forbidden.

From this time, the Scotch Herring Fisheries began to flourish, curiously enough at so late a date, when we remember that the British waters are fuller of Herrings than any other. If we reflect on the present greatness of British commerce, it sounds almost fabulous that up to the middle of the sixteenth century, the Herring Fishery on the British coasts 
was entirely in the hands of the Dutch and Spaniards, and that the Scotch only determined at the beyinning of this century, to work the gold mine that lay before their door.

But, although they appeared late on the scene, they have overcome all their rivals. In 1826, the Scottish fisheries employed no less than 10,633 vessels and boats, with crews of 44,695 fishermen, who handed over the raw material to 76,041 salters. In the same year, the Scotch Herrings were preferred to the Dutch at Hamburgh. Spirit of Beukelings, weep bitter tears at the obscured renown of thy country-men!

The English Herring Fishery is also very considerable. In the small port of Yarmouth, it employs 400 vessels from 40 to 70 tons, the largest of which have crews of 12 men. Three of these boats, belonging to the same owner, brought ashore in 1857,285 lasts, or $3,762,000$ fish, and as $£ 14$ is the price of a last, we doubt whether a whaler ever made a more successful voyage. The importance of the Herring Fishery to Yarmouth is proved by the fact, that 4 to 5,000 men, for at least a couple of months in the year, find employment from it, and that it brings into circulation nearly $£ 700,000$. We must not be surprised, then, that in the Baltic the Herring Fishery is called the great fishery, whaling, on the other hand, the small.

The Herring is, however, a very whimsical gentleman, and plays even his new friends most annoying tricks. There is scarcely a fishing port on the coast of Britain which has not experienced the greatest changes in its visits, both of time and quantity. The real reason of these irregularities is unknown: the firing of cannon, the noise of the steamers, the manufacture of kelp, have in turn been alleged when the wished for Herring delayed its visits. 
But measures have been taken to cure this; and though the Herring now appears in the remote fiords of Norway, and is off again ere the fishermen hear of it, the most marvellous invention of the century - the electric telegraph - is about to be employed in capturing fish. The wire has just been completed in England which is to run along the entire Scandinavian coast from one fiord to the other, and tell all the movements of the fish army to the whole population with lightning speed. Poor Herring! who would have thought when Franklin made his first experiments with the mysterious power, it would be eventually employed for thy destruction!

It was formerly generally believed that the Herring shoals migrate to us from high northern latitudes; but new investigations have proved the utter error of this opinion. The mere fact is decisive, that the Herrings are often seen on the south coast of Treland much earlier than at the places that lie further to the North, and that Herrings are caught during the whole winter on our coasts. Beyond the Polar Circle the Herring is not seen at all, though a smaller species was found by Sir John Franklin on the coast of North Greenland. There can, therefore, be no doubt that it remains in the deep sea during the winter around those coasts on which it appears in such countless numbers from April to November. After spawning is over, it retreats to the deep water, where it is protected against storms and changes of temperature.

Though the common Herring of our northern seas is the most important of all the Clupeæ, there is not a sea or coast on which other varieties of this family do not appear in enormous quantities.

The Pilchard (Alosa pilchardus; Clupea pilchardus, Cuv.) appears on the west coast of France, but especially off Corn- 
wall and Devonshire, in such quantities that, in 1827, this fishery alone employed 10,521 men, and required a working capital of $£ 441,215$.

When the shoals of Pilchards approach the coasts, the peasants of Brittany quit their fields to reap the maritime harvest. Eight to ten men enter a boat of an equal number of tons, sail some eight miles to sea, then lower sail and mast, and throw out the seine, which they spread by continuing their rowing. The master, who stands at the stem, throws right and left as far as he can the roe (rogue), which serves as a bait. This is principally obtained from Drontheim, and consists of various fish eggs. So soon as he sees that the cork floats of the net are moving sharply, and that the surface of the sea is covered with many silvery scales, he knows that a large quantity are caught. He then fastens the net to a buoy, to which he also attaches the end of a second net. Thus five to six nets are thrown out one after the other, and they pull back to the first one, which is emptied while the others are filling.

The Sprat (Clupea sprattus), a small fish hardly four inches long, is caught in such masses off the coasts of Kent, Essex, and Suffolk, that it not only affords the population of London a cheap and pleasant meal during the winter, but is employed to manure the fields. In the winter of 1829-30, the Sprat fishery was so productive that whole cargoes of 1,000 aud 1,500 bushels, which only cost $6 d$. per bushel, were taken to Maidstone as manure for the hop gardens. Nieuhoff's Sardinelle, a Cluper found off the coast of Malabar, is used in a similar way to manure the maize fields and cocoa plantations. The Sprat is just as fickle as the common Herring, and some- 
times degenerates. Thus, on the coast of Ostend it has been bitter and unsaleable for the last four or five years.

The Black Sea Herring (Clupea pontica), which the winds often toss in myriads on the Crimean coast, only requires some improvements in the way of "curing, to gain a great commercial value; and the Herring of New York plays the same important part on the American coast as the common herring in our seas. When writing of the Clupeidx, an Englishman cannot omit notice of Leach's Herring (Clupea Leachii), a native species, or of the White-Bait (Clupea alba, Yarrell), formerly supposed to be the young of the Shad.

The Mediterranean appears to be the real home of the Anchovy (Engraulis vulgaris; Engraulis encrasicolus); at spawning-time it is found by thousands in the shallow water. It is more rarely seen in the ocean. The anchovies of Provence are, without doubt, the best. 'This little breed of herrings is principally canght near Antibes, Frejus, and St. Tropez; and enormous cargoes are taken to the fair of Beaucaire, whence they are transported all over the world.

The fishermen's wives have an extraordinary knack of removing, with the thumb-nail, the head of this little fish, with the entrails and liver attached to it.

After the Clupea, no race of fish is so valuable to man as the family of the Haddocks, which, in addition to the common Haddock (Gadus oglefinus), the Ling (Lota molva), the Whiting (Merlangus communis), and many other agreeable varieties, comprises the Cod (Gadus morrhua). This handsome large fish, which, either fresh or salted, dried in the air or in stoves, is eaten by millions, and is a source of profit to thousands, usually attains a length of two to three feet, and a weight of 
twenty to forty pounds, though Pennant mentions a cod caught ofi Scarboro', in 1775, which was five feet eight inches in length, and weighed seventy-eight pounds. It generally swims in twenty-five to fifty fathoms of water, where it lives on the smaller fish, sepias, crustaceans, in fact anything that comes across its voracity. For this reason, and on account of its weight, it is caught with hooks, and not with nets.

The whole North Atlantic, from Iceland to Gibraltar, and from Norway to Labrador, is the habitat of the Cod; but it is nowhere found in such abundance as on the Eastern Coast of America, where it occupies, between 40 and $60^{\circ} \mathrm{N}$. Latitude, all the bays and shallows to the extreme edge of the great Bank of Newfoundland. So soon as spring approaches, regular fleets set out to capture it: England alone supplies above 2,000 ships, with 30,000 men; France, half this number; America, as many as both countries together. It is calculated that each ship, during the season, averages 10,000 fish; and an idea may be formed of the voracity as well as the number of the Cod, when we state, that a practised fisherman can catch four hundred in a single day, one after the other; but it is terrible work for the arms. Off the Dogger Bank, and on the coasts of Norway and Iceland, the cod-fisheries are also very valuable.

In addition to its excellent firm flesh, the liver-oil of the Cod is frequently employed by physicians; and it has restored many a scrofulous child to health. The bladder is also used by the Icélanders to make isinglass.

The best sort of isinglass is, however, produced from the Sturgeon (Accipenser sturio), a fish which principally inhabits the Caspian, and the rivers flowing into it, the Volga and the Don, although it is also met with in the rivers flowing into the 
Baltic and the Mediterranean. It is also caught occasionally in the Thames. This valuable cartilaginous fish is about eight feet long, and hence occupies a high place among fish. The bladder is prepared in the following way. The mucous skin of the bladder is carefully separated from the external membrane, which is easily done by laying it for a time in water. It is then washed very clean, dried by being pressed tightly in a cloth, rubbed soft between the hands, and rolled through cylinders. After this, it is bleached in the fumes of burning sulphur, and dried in the air. The bladder consists almost of pure isinglass: in cold water it swells, in hot it dissolves; and on being allowed to get cold, becomes an almost colourless transparent jelly. It is frequently employed in the culinary art, and to clarify a variety of fluids. If a strong solution of it is spread on silk, we have court-plaister; and when mixed with gum, it is used for cleansing silk fabrics. In addition to the finest isinglass, the Sturgeon produces the most splendid caviare, which is prepared from its salted and dried roe.

The common Sturgeon (Accipenser sturio) is one of the most

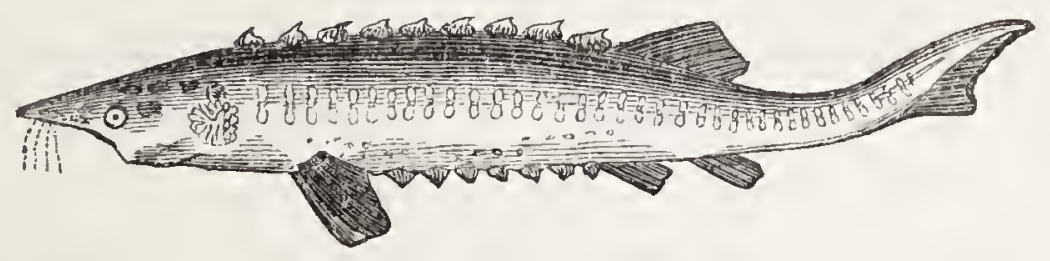

THE COMMON STURGEON.

valuable fishes. It inhabits the German Ocean and the Baltic, the Mediterranean and Caspian Seas; and at times attains a length of eighteen feet, and a weight of five hundred $\mathrm{p}$ unds Its long, narrow, pentagonal body has a row of large, bony, sharp tubercles at each edge. It is still highly esteemed for its firm, white flesh, though not treated with such respect as 
by the Greeks and Romans, who had it brought to table by garland-crowned slaves, and to the accompaniment of music. On the other hand, the smallest of the Sturgeon family, the Sterlet (A.ruthenus), which is chiefly caught in the Caspian and the Volga, is considered an extraordinary dainty, and fabulous sums are paid for it in Russia; for it can only be eaten fresh, and hence has to make a long journey in tanks from its native shores to the kitchen of the modern Luculluses. Prince Potemkin is said to have frequently paid three hundred roubles for a Sterlet soup.*

One of the most important inhabitants of the North Atlantic, and the rivers that pour into it, from Greenland to France, is the common Salmon (Salmo salar), which attains nearly the size of the cod, but far surpasses it in flavour. In spring and summer it quits the sea, to spawn on the pebbly beds of the rivers, swimming up the stream in a triangular phalanx, and often in such numbers, that they check the passage of the water. Neither the rapidity of the streams, nor the height of the waterfalls, which it surmounts with astonishing strength, can check its progress; but it falls a prey to man, who kills thousands of salmon. They are, caught either in nets or in boxes placed behind the weirs; also with spears, either by day, or at night, when the glare of torches attracts it to the surface. In the Liffey, where it often falls back when attempting to leap over the falls, baskets are kept ready for it on the bank; and at the Kilmarnock Falls, in Scotland, branches of trees are laid on the rocks by the country people, to catch the fish after its unsuccessful leap. Nowhere was the Salmon-fishery ever carried on to a larger extent than in the British rivers. There

* The Sturgeon is a great eleanser of rivers. Its head being pecuculiarly shaped to stir up the mud at the bottom.-W. F. A. 
was a time when 200,000 were annually caught in the Tweed; but during the last forty years, complaints have been incessant about the dying-out of this valuable fish. 'The instinct which impels the Salmon to leave salt water every year, and care for the preservation of its fry far up country, and which afterwards conducts the young fish from the sweet water of their first home to the distant salt ocean, is one of the most curious manifestations in the whole of Nature's dominions.

Though the Mediterranean knows not the Herring, the Cod, or the Salmon, the capture of the Tunny affords the inhabitants of Sicily and Provence some compensation for their loss. The flesh of the Thynnus vulgaris which usually attains a length of from two to three feet, but at times reaches to eight or ten, is firm and fibrous like that of the Sturgeon, but far better tasted. In May and June, the Tunnies appear on the coasts of the Mediterranean in large shoals, swimming in a triangle; they are very timid, and the apprehension of danger drives them back to sea: but this is employed to destroy them; for on their approach being signalled by the scouts lying on the rocks, boats put off far to sea, and drive the shoal ashore, when it is surrounded by nets, and the fish are killed with long staves. The 'Tunny fishery is carried on upon a large scale with the French Madrague, or the Sicilian Tonnaro. Rows of long and broad nets, weighed at the bottom with stones and lead, and kept upright by means of cork floats, form a wall parallel with the coast, and extend at times for more than an Italian mile. Cross nets divide it into several chambers, in which small openings are left landwards. The fish run their heads against the net, and are compelled to escape through the nearest opening. Through this antechamber they are driven further and further into still narrower prisons, till they reach 
the last called the chamber of death. Here they are brought to the surface by means of a strong horizontal net; and the work of destruction begins by killing them with long sticks. This scene is one of the great amusements of the rich Sicilians; and the fishery is one of the principal resources of the Island. When Louis XIII visited Marseilles, a fish massacre was arranged in honour of him, which so delighted the sensitive monarch that he was often heard to say that it was the pleasantest day he ever spent throughout his journey to the South.

The common Mackarel (Scomber L.) belongs to the same species as the Tunny, and deserves mention, both for its excellent meat, and its graceful form. It dies almost immediately on being taken out of the water; and, as it soon putrifies, an exception is made in its favour in Sabbath-reverencing England, and it is allowed to be sold on Sundays. Like all the varieties of the Scomber, it is very voracious, and produces severe ravages among the herrings, although itself rarely exceeding fourteen inches in length. Like the herring, it was formerly supposed to migrate; but the probability is, that it only retires to deeper water during winter. It is an inhabitant of the North Atlantic; and large quantities are caught on the British coast. It is taken in long nets, but principally with the hand line. It will bite at any bait; but as a rule prefers anything glittering, such as a long shining piece of a brother fish, or a piece of tin, a sixpence with a hole in it, or a piece of scarlet cloth. The boat proceeds quietly under sail; and there is one wind so favourable for the fishing that it is called the Mackarel-breeze. The line is short, but weighted with lead; and in this way a couple of men can catch a thousand a day. The quicker the boat moves, the greater the luck; for the 
Mackarel shoots sideways at the bait.* The drift-nets used in this country in the Mackarel fishery are well corked at the top, but without lead at the bottom.

The last member of the Scomber family (Scombridee) we have to mention is the Bonita, which is one of the fiercest persecutors of the flying fish in the tropical waters. It has a likeness to the Tunny, but is of a more graceful shape, and hence cleaves through the sea at a higher speed. It belongs to those rare, pelagian fishes, which are met in shoals, in blue water far from any land.

The common Eel (Murcena Anguilla) is too well known to require any full description. It generally lives in rivers and ponds, but is also found in the sea. In the Baltic enormous quantities are caught at times. The usual length is two to three feet; but they have been caught six feet long, weighing 15lbs. Although susceptible of heat and cold, the Eel can live for a long period, according to Pliny, six days out of the water, so that it at times crawls about meadows and damp places, to chase snails and worms, a faculty which it owes to the small opening of its gill-flap. Its proverbially slippery skin is used in some countries, on account of its brightness and transparency, for window panes, and to make whip-thongs and harness. Yarrell describes three species of Eel as found in this country. Anguilla acutirostris, or Sharp-nosed Eel, the broadnosed Eel, and the Snig (Anguilla medirostris).

The Roman Muræna (M.Helena) is akin to the common Eel, both in size and in its mode of life. Its dirty greenish brown skin is covered with dull yellow spots. Although it can live in either sweet or salt water, it prefers the latter,

* A capital account of Mackirel-catching will be found in Maxwell's "Wild Sports of the West." 
especially the coasts of the Mediterranean. We mention the Muræna, principally on account of the strange fondness the Romans felt for it, and by which it has even achieved an historic reputation.

They were fed in large artificial tanks or Piscince, which, we read in Pliny, were first employed by a certain Caius Hirrius, who lived in the time of Julius Cæsar. Soon after, fattening Murænæ became a passion with the Patricians and Knights. At Bauli on the Gulf of Baiæ, now Baja, the orator Hortensius had a piscina, when he took such delight in a favourite Muræna, that he burst into tears on its premature decease. In the same Villa, Antonia, daughter of Drusus, had valuable rings (inaures) fastened on one of these slippery favorites, so that people walked for miles to gaze at the richly adorned fish.

The Knight, Vedius Pollio, even attained a scandalous immortality through the Murænæ. He used to cast among them slaves who had committed any crime, and revelled at the sight of the gnawed and lacerated corpse. As this monster was a friend of Augustus, this does not at all agree with the ideas of the urbanity of the court, which we feel on reading Horace or Virgil.

The Conger (M. conger; Anguilla conger, Shaw; Conger vulgaris; Le congre, Cuv.) is distinguished from the common Eel by its white-spotted lateral line, its tentacles growing from the upper jaw, its darker colour, its shorter under-lip, and its size. Congers have been caught ten feet in length, and weighing one hundred pounds. It inhabits the North Atlantic and its bays, and the Mediterranean; and in the spring makes its appearance at the mouths of rivers. Large numbers are caught off the coast of Cornwall and Devonshire, and after being dried, they are exported to Spain and Portugal. The 
Conger is very voracious, and appears fond of eating crabs when they have cast their shell.

Although the Lamprey (Petromyzon Marinus) differs materially from the eel family in the structure of its gills, the softness of its cartilaginous frame, and its funnel-shaped mouth studded with hooked teeth, we will mention it here, on account of its external resemblance. The Lamprey is about three feet long, and of a dusky dim green colour. It inhabits the sea; but usually swims up the rivers in spring. Although it can move very fast by means of its snake-like wriggling, it is usually found with its mouth affixed to a large stone, to which it adheres so firmly that a weight of upwards of twelve pounds can be picked up with it without it loosing its hold. Like the eel, it takes a deal of killing; and the head when cut from the body, will continue sucking for hours. The Lamprey has been considered a delicacy for centuries. Henry I. died of an indigestion produced by indulging to an excess in this dainty dish; and every Christmas the city of Gloucester presents Queen Victoria with a Lamprey pasty, as it was wont to do under the Plantagenets and Tudors.

The Slime Eel (Myxine glutinosa) bears a great likeness to the Lamprey, but stands at a far lower class of organization, as it (the only one of the fishes) has no eyes, and possesses a much softer skeleton. When boiled, it dissolves almost entirely into slime. Instead of seven gill-holes on either side, it only has one on each side the stomach, an arrangement which is admirably adapted for its mode of life, for it digs deep into the entrails of fish. Thus, in this, the lowest of the vertebrate animals, the same harmony between its structure and its wants is found. 
The family of the Flat Fish, or Pleuronectidoe to which the Halibut, Turbot, Sole, Plaice, \&c., belong, commends itself to our attention, not only through its strange unsymmetrical form, but also through its utility for man.

Their eyes lying above each other on the same side of the head, and the skew mouth running vertically, make their appearance something frightfully odious; but the fitness of this arrangement soon reconciles us to the apparent monstrosity. As they lie nearly always on their side on the slimy or sandy bed of the sea, an eye on the lower side would be evidently useless for them, while both organs of vision on the same side command a wide field, and not only facilitate their finding their prey, but inform them of the menacing approach of a powerful enemy, We have already mentioned that the natatory bladder is absent in the flat fish ; for this organ would have been of little use to them, as they live on the bed of the sea, and are not intended to traverse the water in every direction like most of the fish. The upper side of the flat fish is of a dark colour, the other perfectly bright and white, fortunately for the defenceless creatures; for if, as is usually the case, the back and belly were of different colours, their piebald appearance would betray them to their foes. They swim along slowly in a horizontal position ; and it is very advantageous for them that the ventral and pectoral fins on the lower side, where there is so much less space for their movements, are much smaller than those on the upper side. At any sudden alarm, they travel at a great speed through the water, in a vertical position, and flash past the observer with a meteoric glance; but they soon return to their ordinary position, and, on account of the great similarity of colour, can hardly be distinguished from the slimy bottom. 
The number of species decreases as the northern latitude increases. In England there are sixteen; on the coasts of Norway, ten ; in Iceland, five ; and in Greenland, only three varieties.

Many of them attain a considerable size, especially the Halibut or Holibut (Pleuronectes hippoglossus; Hippoglossus vulgaris, Cuvier and Fleming). In April, 1828, a specimen, seven feet six inches long, three feet six inches broad, and weighing three hundred and twenty pounds, was caught off the Isle of Man, and sent to the Edinburgh market. Olaus tells us, that he had seen fish of this species five ells in length; and the Norwegian fishermen assert that a single Halibut will at times cover a boat. But we should act wisely in remembering, that these stories come from the homes of the Kraken and Sea-serpents. At any rate, the Halibut deserves the title of Maximus much more than its congener, the Turbot, which is found in the Mediterranean as well as the German ocean; and was regarded by the Romans as the greatest ornament of their epicurean tables, as Juvenal's well-known satire sufficiently proves to us. It is often confounded with the former fish ; but is easily distinguished by the large irregular rounded tubercles on the upper side of its body. It is principally caught off the north coast of England, and commands a high price. In one year no less than 87,978 were sold at Billingsgate.

Among the flat fish, the Sole (Solea vulgaris, Cuv.; P. solea) is inferior to the Turbot alone in flavor. It inhabits the sandy bed of the sea, where it lives upon small testaceous animals and the young fry of other fish. Its territory extends from the Baltic and the Scandinavian coasts to Spain, Portugal, and the Mediterranean. An immense number is caught with 
the drag net round England, and 86,000 bushels found their way to London in one year.*

Even more common is the Plaice (Platessa vulgaris, Cuv.; P.platessa), which is reckoned among the inferior flat fish. Once such a quantity was brought to Billingsgate, that though many hundreds were sold at $3 d$. a dozen, a large pile was left. A dealer, who tried in vain to sell 100 bushels at $4 d$. the fifty fish, gave them to the poor.

The Rays resemble the flat fish, as regards their form, but differ from them materially in many other respects. Like the Shark and the Sturgeon, the Ray is a cartilaginous fish, and is the ugliest of the whole family. Its clumsy broad body, its long narrow tail, generally armed with one or more rows of sharp thorns, the dirty colour, and the covering of slime, indubitably stamp it as one of the most repulsive creatures nature has formed.

Though the flat fish are so defenceless, the Ray employs its tail excellently to repulse any hostile attack. If a suspicious form approach it, it rolls itself up with its head against the root of the tail, and flogs away with the latter in every direction.

The Sting Ray of the South American waters inflicts very serious wounds with its double-pronged, barbed thorns. An Indian who accompanied Sir Richard Schomburgk, was stung by one, and he fell on the sand and rolled about, biting his teeth in agony; but not a tear escaped from his eye - not a cry was heard from the suffering savage. A boy, less master of his feelings, when stung in a similar way soon after, uttered a piercing yell, threw himself on the ground, rolled face and head in the sand, and even bit at it. Only epileptic persons, * "Yarrell's British Fishes," rol. ii. p. 25. 
Schomburgk declares, could fall into such convulsions. Although both were stung in the foot, they felt the greatest pain in the temples, the neighbourhood of the heart, and under the arms. Still, this cannot be produced merely by the wound - it is very possible there was some poisoning influence at work. A labourer, stung by a Sting Ray in Demerara, died in the most terrible convulsions.

The Rays are very voracious. All fish, naked and shelled, molluscs and crustaceans, that they meet are swallowed without distinction. 'Their masticating muscular jaws are so powerful that they crush the hard shells, of the crab with ease. In our seas, they attain considerable dimensions: Willoughby mentions a Skate (Raia batis), weighing $200 \mathrm{lbs.,}$ which afforded an ample meal for 120 professors and students at Cambridge. But all the European varieties are far inferior in size to the immense Devil Rays or Sea Devils (Cephaloptera diabolus) found near the South Sea Islands. This monster lives with his fellows, and frequently comes to the surface, where it looks like a flat reef. It is from 12 to 15 feet broad, and Letson obtained from a fisherman at Borabora a tail of this animal which was five feet in length. The inhabitants of the Society Islands kill the Devil Ray with harpoons, and employ its raw skin to rasp their wood work.

On his voyage to Africa, M. Vaillant saw, in $10^{\circ}$ N.L., three Giant Rays swimming round the ship. He only succeeded in catching the smallest; but this measured 28 feet across, and $21 \mathrm{in} \mathrm{length} \mathrm{to} \mathrm{the} \mathrm{root} \mathrm{of} \mathrm{the} \mathrm{tail,} \mathrm{which} \mathrm{was} \mathrm{only} 22$ inches long. The mouth was so large that it could swallow a man with ease: the back was brown, the stomach white. Its weight was estimated at two tons. 
Such voracious and well armed animals as the Rays, would have attained a dangerous supremacy, if they were as prolific as most other fish. Fortunately they only bring into the world one young one, which, as among the sharks, is enclosed in a quadrangular fibrous case, and swims around freely after its prison is burst.

Here nature has again provided for the necessary restriction of an otherwise overpowering race; while, in other cases, she prevents the extirpation of the creatures with which she has populated the sea, by the countless eggs they lay.

If the Cod did not annually lay nine million eggs, as Leuwenhoek counted; and the Sturgeon above seven millions; if flat fish, and Mackarel and Herrings, were not propagated by hundreds of thousands, they could not possibly hold their own against the infinity of their enemies. "Not an egg too much," every one will say, who reflects that out of the fisheggs left in shallows or coasts, or in rivers, to be incubated by the enlivening beams of the sun, hardly one in a hundred produces a living creature; that fish and molluscs, crustaceans and sea birds, swallow the spawn with equal voracity: that, further, danger threatens the young defenceless fry from every side; for might is right, is the rule in the ocean: and, lastly, that the insatiable voracity of man has to be satisfied. But if very few fish die a natural death, or of old age, their free life, at any rate, offers them some compensation from this death by violence. What martyred cart-horse, or caged singing bird, would not willingly exchange its miserable fate for that of the free fish, which, besides, through the greater simplicity of its structure, its want of higher sensibility, its powerful digestion, and, above all, through the more even 
temperature of the element in which it passes its life, is not exposed to those numerous diseases which attack warmblooded creatures, and domestic animals more especially.

Still, the proverb, "Sound as a roach," must not be taken as strictly true. 'Thus, the Salmon-trout suffers from a leprous disease; the Carp, from an eruptive or cutaneous complaint; the Perch, from dropsy; the Eel, from a frequently mortal disease of the skin; and nearly every fish is tormented by worms, which frequently produce internal ulcers. When the circumnavigator, Dumont D'Urville, stopped off the Auckland Islands, he found the flesh of all the fish caught there traversed in every direction by long worms, which gave it a marblea appearance. At first, the sailors paid little attention to this, as they considered these worms were blood-vessels; but when they noticed that their officers no longer ate them, they returned to their salt pork. D'Urville had apparently healthy fish of every description cut open, and found them nearly all attacked by the same worm disease.

Some of the fresh-water fish, such as the Carp and Pike, attain a very great age; of course, we do not know so accurately to what length the marine fish spin out their thread of life, although the enormous size of some Halibuts, Tunnies, Cods, Rays, etc., seems to indicate a really patriarchal age. Two methods have been suggested to decide the age of fish. If their scales are examined through a microscope, they will be found to consist of concentric rings, which some persons fancy are of the same nature as the yearly rings on the trunks of trees; and when the scales are wanting, as in the Rays, the rings on the joint-bones of the vertebræ give a similar account of the age of the animal. 


\section{CHAPTER VI.}

How do mine Crustaceans differ from Insects and Spiders?Organs of Respruation in the Crustaceans. - The Crab.Tenacity of Life.-The Horseman.-Cancer Pagurus.-The Japanese Giant Crab. - The Pinnotheres. - The Hermit Crab.-The Prawn.-The Lobster.-The Process of castivg its Shell. - Voluntary casting off Limbs.-Extraordinary Metamorphosis of the Crab.

THE Crustaceans (Lobsters, Crabs, Prawns), are reckoned by Linnæus among the insects, like the centipedes and spiders; but in reality they differ greatly from them, and, owing to their number, occupy such a large space in the animal kingdom, that they have been elevated, by later naturalists, into a separate class.

It is true, that they possess, in common with the insects, an articulated body, covered with a shell more or less hard; the same feelers, and masticating implements formed much after the same fashion; but while the insects breathe through windpipes or tracheæ, the Crustaceans (with the exception of the Woodlouse) are exclusively aqueous. The perfectly developed insect is incapable of any further growth; the Crustacean, on the other hand, increases in bulk with every year. The Crustacean possesses a heart, which receives and circulates 
the blood, after it has been purified by the gills. In the insect, the vascular system is far less fully developed. No insect has more than six legs; no Crustacean less than ten.

The Myriapods or Centipedes inhale air like the insects, and are distinguished by the elongated structure of the body.

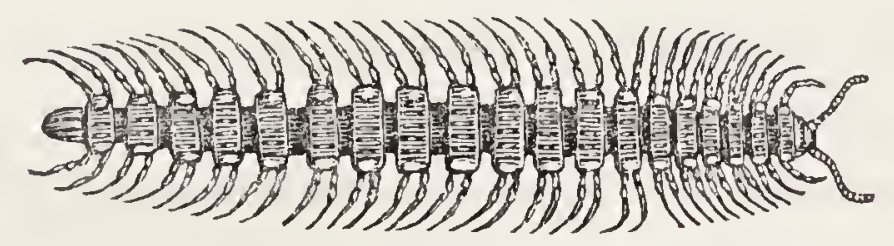

THE CENTIPEDE.

As their name indicates, they are provided with a large number of organs of motion, and surpass, in this respect, the most richly endowed Crustacean. The Spiders, above all, the Scorpions, bear the greatest similitude to the class now occupying us; but all the Arachnidæ have only eight legs, and usually possess the same number of eyes; while the Crustaceans have only two eyes, which are attached to foot-stalks in the higher varieties. The claws of the crabs and lobsters are really forelegs, which serve both for crawling, and seizing their prey; while those of the scorpion are merely peculiarly-shaped feelers, and do not aid motion in any way. Usually, the scorpions are land animals, while the Crustaceans belong almost exclusively to the water; for, though some varieties, such as the Woodlice, live in damp places, and the true amphibian (Grapsus talitrus) lives chiefly on the strand, and rarely goes to the waves: on the other hand, the greater portion of the Crustaceans dwell in streams and rivers, but, above all, in the ocean, where their legions are found on every coast, or populate the waste of waters far away from land. 
'The respiratory apparatus of the Crustaceans offers many interesting features. In some of the lower varieties, we find the organs of breathing hidden in the legs, whose extremely thin and delicate covering allows the blood to be properly refreshed. In these animals, breathing and motion are synonymous.

In others, the gills have the shape of bunches of feathers, and swin freely in the water like fins; or they appear like membranous bladders attached to the base of the fore-feet. In the higher varieties, such as the lobsters and crabs, they are contained in two chambers, which lie under the breastplate, and are provided with two entrances: one in front near the paws, and a posterior one. The latter, in the long-tailed Crustaceans (lobsters), is a widely gaping crevice at the base of the feet; in the short-tailed (crabs), a small cross-slit opening in front of the first pair of feet.

Owing to this arrangement, the crabs, like those fish provided with a narrow gill-flap, are enabled to live much longer on land, than the long-tailed variety. We find among them, indeed, sone specimens so remarkable in this respect, that they are called Land-crabs (Birgus, Gecarcinus, etc.). But, in order to retain the necessary supply of water, we find in these varieties peculiar cell-like hollows in the inside walls of the gillcavity, filled with a spongy matter. To this we must add, that, between the several gill-plates, there are remarkably hard continuations, which, in the event of an utter want of water, prevent any adhesion of the gills, and the stopping of the circulation which this would necessarily produce.

In fishes, as we have seen, the water that promotes respiration, flows from front to back, in order not to impede the move- 
ment of the animal; in the crabs and lobsters, to harmonise with their retrogressive movements, provision is made that the current of water shall overflow from back to front.

So wondrously is everything arranged in the anatomic struc. ture of these animals for the wants of their peculiar mode of life!

All Crustaceans, however much they may differ in their external form, are constructed on the same fundamental plan. In the lower orders, the body consists of a row of almost equal large rings, each provided with a pair of prehensile or natatory feet. But when we ascend to the higher forms, we find a gradual concentration of the body, by the rings being converted more or less into large, firm pieces. This is found most perfectly in the crabs, whose large, firm shell only evidences its compressed condition by the five pairs of legs, which grow from the lower surface.

Crabs are never met with in the high northern 'seas; their number increases with the warmer temperature of the waters, so that several sorts are found on our shores; but their principal habitat is the tropical zone. Here, the most remarkable and various types are found; here, they attain a size unknown in our seas; here, lastly, they do not live exclusively, as among us, in the salt water, but populate streams and rivers; or, like the Thelphusæ and Gecarcinians, remain permanently on land. Among the latter, there are, indeed, some varieties which are so estranged from the water, that they are soon stifled if plunged into it. It is true that they breathe through gills; but the small amount of oxygen dissolved in the water, does not satisfy the wants of their lively respiration. They generally inhabit damp forests, often far from the coast, on the hills 
in the interior, and conceal themselves in self-dug holes. At a eertain period of the year, they are led by their instinct to the sea; they then collect in large crowds, and frequently make lengthened journeys, permitting nothing to turn them from the direct route, and destroying everything they come across. They live principally on vegetable substances, and are nocturnal or crepuscular animals; at night, they may be seen running about at a considerable speed.

All the sandy and slimy coasts of the tropical seas, which afford sufficient protection from the surf, swarm with crabs. In the East and West Indies, the Land-crab (Gelasimus vocans) digs deep holes in the beach. In this curious creature, one claw is much larger than the other, and sometimes is so enormously developed, that it exceeds the rest of the body in size. It employs it as a door, to guard the entrancc of its hole; but far from being any hindrance in moving, this crab can march at such speed, that it is difficult to catch. At the same time, it raises its monstrous claw in the air, so that it seems to be making use of it like an outstretched hand. It appears to be making sport of its pursuers; and, confiding in its speed, expresses in pantomime: "You cannot catch me."

So soon as the ebb-tide lays bare the pestilential soil of the Mangrove forest-shore, it is found to be inhabited by countless animals. Here quivers a fish; there creeps a Holothurian; and crabs run about by thousands. The black mud on the coast of Borneo is often preyed upon by the myriads of the Gelasimus ceruleus, which has a great partiality for dirt.

The Venetian lagunes also shelter a countless number of common Crabs (Portunus monas), the capture of which is a very important branch of the fishermen's trade. Entire car- 
goes are exported to Istria, where they are employed as bait for the Sardines. The fishermen collect them shortly before they shed their shells, and place them in baskets in the canals. When the operation is performed, the crabs are served on the first tables under the name of Molbeche. The fishery during the year is valued at 500,000 liri. When an attempt is made to capture this crab, it runs away hastily sideways, and buries itself in the mud. If this recourse fail, it beats its claws noisely together, and stands on its defence like a true warrior.

The most valuable crab in the German Ocean is undoubtedly the Broad Common Crab (Cancer pagurus), hundreds of thousands being sold annually at Billingsgate. It is caught in ozier baskets, so made that they permit an entrance, but prevent a retreat. Although of a very fair size, it is, however, but a dwarf when compared with the Giant Crab, found in the Sea of Japan. This variety is little known; but, judging by fragments, it must attain an enormous size. Tamarik saw some fore-legs of the thickness of a human arm; and the shells are said to be above a yard in width.

The organs of motion in the Crabs are of very various shapes. In what are called Spider-crabs, the legs are very long, thin, and weak, so that the animal is a bad swimmer, and can only walk slowly and hesitatingly. Hence, for greater security, it keeps in rather deep water, concealing itself beneath seaweed, where it wages an incessant war with annelids, planarix, and small, shelly animals. Spider-crabs are frequently found on oyster-banks, and are considered by the fishermen destructive. Hence, they are not thrown back into the water, but taken on land, where they are speedily disposed of.

In other varieties, the legs are muscular, strong, and com- 
pact, so that they can move the body along at a considerable speed. The tropical Land-crabs are very remarkable for this quality, as are also the varieties Ocypoda and Grapsus, which form the connecting link between these and the Marine Crabs proper. The Horseman (Ocypoda cursor), which is found on the coasts of Syria, Africa, and the Mediterranean, is indebted for this name to its velocity; for it cannot even be caught up by a mounted inan. The Ocypoda of North America and the West Indies, dig holes about three to four feet deep, just above high-water mark, and come out at night. Towards the end of October, they go up country, and conceal themselves during the winter in similar holes, whose openings they carefully close.

In the Portunus, or real Sea-crab, the posterior pair of feet have a fin-like elongation, so that, though they would play rather an ignominious part on land, they can paddle about all the quicker in their native element.

A peculiarity in these crabs is the large number of parasites which they drag about on their backs. In Mr. Hyndmann's collection is a spider-crab, whose hairy shell, only $2 \frac{1}{4}$ inches in length, bears an oyster three inches long, and four to six years of age, which is also covered with many large acorn-shells. The poor beast, like Atlas, had to groan beneath the weight of a world.

Oetke describes a spider-crab the size of a boy's hand, which had dozens of acorn-shells, old and young, on its back, and even several on its legs and claws. Between these were. little weeds, and among these and on the acorn-shells, lived an army of phosphorescent animals, which lit up the little world with a flickering light, when water was poured on it in the dark. This spider walked about in the sea in this guise, but it evidently suffered from its weight, and was soon crushed by it. 
It would, however, be wrong to regard the burthen many a crab lays about it as quite useless, for it may be a stratagem to which the crafty crustacean owes many a dainty morsel. Thus Bennett saw at Otaheite a spider-crab, which had covered itself with fucus and coralline sand. 'The powerful bent thorns on its back did it excellent service in this. The short claws were carefully concealed, and the long footstalked eyes (we forgot to mention that in all the higher crustaceans, long or short-tailed, the organs of sight are attached to moveable stalks) peered over the piled up material. If an unlucky, unsuspecting mollusc came within reach of the ambushed rascal, it shot forward and held the poor wretch in its jaws, before it had time for reflection.

If some of the crabs have a weight of animals and plants to carry about ; there are, again, others which live parasitically in the shells of various molluscs. Thus, the little Pinnotheres veterum joins the great Thorn-mussel (Pinna) of the Mediterranean. Many fables liave been invented about the friendship existing between these animals. Pliny asserts, that, when the widely opened shell of the Pinna is filled with a sufficient quantity of small fish, the crab tells its blind host the right moment for closing by a gentle bite (leni morsu), after which the allies share the plunder. According to others, the Pinnotheres is the faithful guardian and commissary of the bivalve. When it returns from its foray laden with booty, the Pinna opens to it at a sign, and receives as a reward of its hospitality a rich share of the prey. If a foe approach, the crab at once warns its dear comrade, who lives a life free from care, confiding in the watchfulness of the crab. Unfortunately, there is not a word of truth in all these marvellous stories. The sole reason why the little Pinnotheres takes up its abode in the strange 
shell, is the softness of its covering, which would expose it to attack; nor is the Pinna found to display any peculiar affection for its so-called guardian; for the latter often has much trouble ere it can creep into it again.

According to Thompson, the Modiola vulgaris, a species of esculent mussel, which is very frequently found on the Irish coast, is obliged to shelter several Pinnotheres ( $P$. pisum). At Heligoland, Oetke rarely found a modiola which did not contain a couple of lodgers; but he never found crabs billeted on oysters, esculent mussels, or other allied varieties. What can be the reason for that preference, and this aversion ?*

The immense family of Paguri or Hermit Crabs is also con. demned to a parasitic or predatory life by its structure. The anterior part of the body is equipped, as in other crabs, with breast-plate and claws; but terminates in a long soft tail provided with two hooks. The posterior part is not formed for swimming, and its weight prevents it crawling. Hence no resource is left but to look about for a suitable support; and this is offered it in various Spiral Shells, Periwinkles, Nerites, \&c., to which the Hermit Crabs affix themselves so firmly by means of their hooked tails, that the house seems to belong to them. So long as they are young and weak, they may be content with empty shells; but when they are of larger growth, they attack living specimens, seize the molluscs with their tails, before they can draw back, and after devouring the tender flesh of their victim walk with the utmost coolness into the house, which fits them most comfortably, and whose opening they guard with their larger

* The Pea-pinnotheres (Pinnotheres pisum) is said to be met with in all bivalve shells.-W.F.A. 
claw, just as the original owner did with its lid.* If the Paguri find their home too tight for them, it costs them but small trouble to obtain another; for, wherever they are found, there is always a number of sea-snails. Paguri are found on nearly every beach, and almost every new voyage of discovery produces fresh varieties, so that they are the commonest of the Crab family. At the Mariannes, New Guinea, and Timor, they are present in enormous quantities, according to Quoy and Gaymard. The beach of the islet of Kewa, in Coupangbay, is perfectly covered with them. In the hot hours of the day, they seek the shade of the bushes; but when evening approaches, they make their appearance by thousands. Although they put up with any large shell, they are chiefly found here in the Nerites.

The celebrated East Indian Purse Crab (Birgus latro), a connecting link between the long and short tails, bears a great resemblance to the Paguri. It is accused of climbing the cocoa palm and plucking the heavy fruit; but Darwin, who frequently observed it on the Keeling Islands, assures us that the crab feeds on the fallen nuts. In this it evinces a degree of skill, which is one of the most marvellous instances of instinct. We may remark, that its anterior pair of legs is provided with very large powerful claws, while the hindermost terminate in small weak nippers. When it has selected a nut for its meal, it begins by pulling off the fibrous shell, and always on that side where the three eye-holes are. Then it hammers away with its heavy claw at one of these, till the door opens. Finally, it turns round, thrusts its nippers

* Mr. Lewis, in his "Sea-side Studies," contradicts this fact. Who shall decide when doctors disagree? 
through the holes, and pulls out the soft, delicious fruit. It lives much on land, and inhabits deep holes, where it piles up an astounding quantity of cocoa fibre, on which it rests softly and comfortably. The tail is filled with a buttery substance, which is said to be excellent eating. A single Birgus wili sometimes yield a bottle of oil. Bad times are, however, impending over it, at any rate, on the Keeling's Islands, as, to the great annoyance of Mynheer, the English have recently taken possession of them, and will grievously disturb the poor Purse Crab.

The long tail which the Pagurus hides in shells, forms, in the Lobster and the Prawn, a most magnificent organ of motion, for though these animals have finely formed legs, owing to the peculiar formation of the body they can crawl but slowly. But nothing can surpass their speed in swimming, or rather in shooting backwards through the water. With a single blow of its powerful tail, which terminates in a broad paddle, the lobster will come a distance of twenty feet. The little prawn (Crangon vulgaris) though unable to take such leaps, in proportion to its size, is in no way superior to the lobster in its power of motion, and is indubitably one of the most active denizens of the sea. It is found in countless numbers on the sandy shores of the German ocean, not far from the water's edge, where it swims on the surface, at times leaping into the air like a sportive insect. The fishermen go about a couple of feet into the sea, and throw before them a net fastened to a long pole, which they empty from time to time into baskets hanging on their backs.

The Squilla Mantis, of the Mediterranean, which is rather like our prawn in shape, differs, however, materially from it, 
from the fact that its gills hang freely like fins from the ventral feet. It is very good eating, and holds a high position among the frutti del mare.

Of all the Crustaceans, none stand so high in estimation as the Lobster. It lives chiefly in deep blue water, on rocky coasts, where it is caught in baskets known by the name of Plumpers. These consist of a thick iron ring, to which a weighted net is attached, the bait being placed in the centre. The ring is let down by means of a small cord, worked by a cork float, and pulled up about half an hour later with a sharp jerk, so that the lobster may fall into the net. This mode of fishing can only be employed in deep water; for the dining lobster, although enjoying the dainty meal, would notice the movement of the boat, and escape the danger. At least 200,000 lobsters are annually exported from Norway to England alone. Great numbers are also caught on the rucky coasts of Ireland and Scotland.

The lobster fishery is also of great importance to Heligoland, and formerly must have been even more considerable. At the beginning of the last century, the fishery was let out to a London speculator. In 1713 he caught about 18,000, and in 1714, 34,989. The first lobsters of the season are often sold for a dollar a piece.

We see thus, that the commercial value of these animals is rather considerable; and, yet, they are a long way from being so valuable as the small Herring Crab (Cancer halecrm) of the Northern seas, which is of the greatest intermediate use to man, as it is the staple food of the herring.

The Lobster lays, in the summer months, many thousand eggs in the sand, leaving the further care of its progeny to 
the blessed sun, and the instinct which is aroused immediately after birth. It may be imagined that only a small portion of them grow large enough to parade in red livery on the tables of the rich. Like all the crustaceans, the lobster casts its shell yearly, and that so perfectly, that the rejected shell with all its feet and feelers, bears a most deceptive resemblance to a full lobster.

When we reflect on the hardness of the covering and its numerous offshoots, especially the broad claws affixed to so narrow a neck, we ask ourselves, with some amazement, how the animal sets to work to liberate its body from such ligaments. We will give a short account of this remarkable process, as it has been watched in tanks in which lobsters are kept.

When, toward autumn, the time for casting the shell approaches, the animal retreats to some secluded nook, like a pious hermit to his cell, and fasts for some days. The shell gradually separates from the body, and beneath it a new tender membrane is found. About this time, the old garment seems to annoy the lobster excessively; for it is seen to make the most strenuous exertions to break off all existing relations with it. Presently the shell bursts asunder up the back, like a ripe seed-pod, and leaves a broad exit for the animal which is panting for freedom. After considerable pulling and hauling, legs, tail and claws follow the body. The claws, of course, cost the lobster the most trouble; but it knows that perseverance will accomplish the most difficult task, and does not stop till it has drawn the elastic mass through the narrow gateway. We can comprehend that the animal, after such a hot fight for liberty, must feel greatly exhausted. Conscious 
of its weakness and insufficient means of defence, it retires for a season, modestly and timidly, from all society. It is most afraid of its physically, as well as morally, hard brethren; for they are delighted to fall on such a defenceless fellow, and devour him, tail and claws, without ceremony. The owners of the Lobster-tanks hence keep careful watch, and when they perceive that one of their prisoners is about to cast its shell, they remove it to a separate tank, where it is allowed to grow soft without peril.

The common Crawfish (Palinurus vulgaris) is equally as valuable as the Lobster in the German Ocean, the Mediterranean, and the West Coast of France. It grows over four feet long, and attains a weight of 12 to 15 pounds. The long prickly feelers are bent backwards, the rough down-covered shell is of a greenish brown, and the tail marked with yellow spots. The meat is held in high estimation. Like the Lobster, it lives on rocky coasts, where it prefers to hide itself under stones.

Very curious, too, is the ease with which crustaceans can throw off their legs, and even their heavy claws, when wounded in one of these limbs, or alarmed by a storm. They run away, without any appearance of pain, on their other legs.

After a while a new limb grows from the old stump, though it never reaches the size of its predecessor; thus, crabs are often found with one claw larger than the other, which is evidently of more recent growth.

The wonderful metamorphoses of insects are generally known; but no less extraordinary are the changes young Crabs undergo ere they attain the form of the old ones. To Mr. Vaughan Thompson we are indebted for the first dis- 
covery of the metamorphoses of the common Crab; and the development of other varieties has since been observed by several naturalists, so that, in all probability, the higher crustaceans are compelled to pass through similar stages of existence.

Before Mr. Thompson's discoveries, the small animals which are now proved to be young Crabs, were regarded as a separate family and placed in a quite different order of crustaceans, under the name of Zoëa.

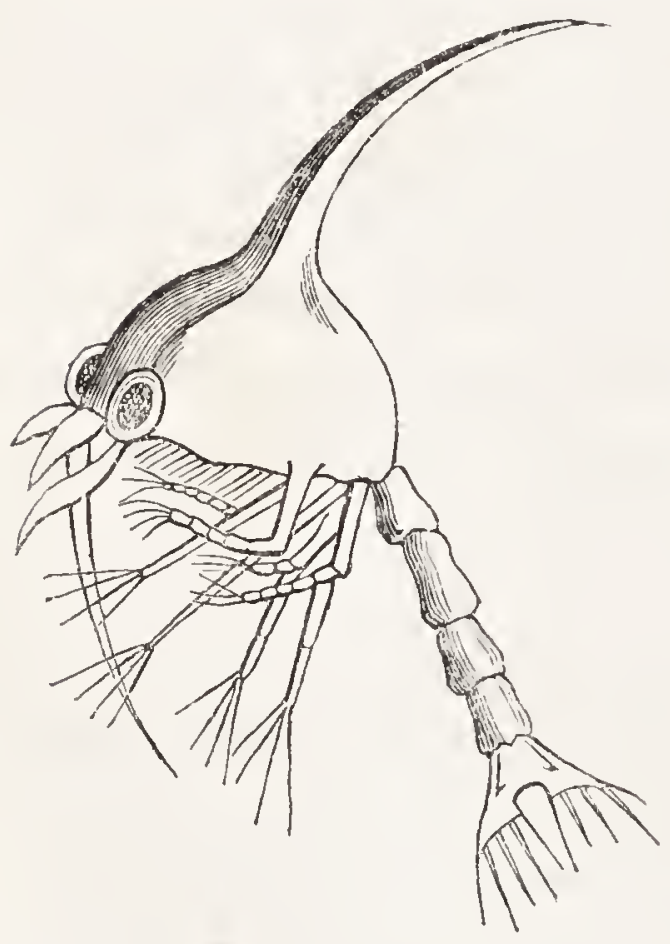

ZOEA OF TIE CRAB.

On crawling out of the egg, the larva appears in a very strange shape. Picture a clumsily large, helmetshaped heaả, terminating at the rear in a long point, and having on either side an enormous eye. By the help of a long, pointed natatory tail, the animal is continually turning head over heels. The claws are absent; while the old Crabs have eight legs, the young ones have only four, which are provided at the end with long bristles, and convey food with great speed to the incessantly active fringed mouth.

Who would believe that such a being could ever be converted into a Crab, to which it does not bear the slightest resemblance? But allow omnipotent time to do its work. Immediately after the first change of skin, the body begins 
to assume something of its future permanent shape: the eyes already project on foot-stalks; claws and feet are developed; but the metamorphosis is still imperfect, for the tail remains long, like that of the Lobster, and the young Crab still revolves rapidly in the water. In the succeeding stage, when the little creature is about the eighth of an inch in diameter, the crabform is fully developed, as the body disappears beneath the shell.

The sole changes which are henceforth perceived are the already described annual sheddings of the shell, which are rendered necessary by the further growth of the now perfect animal.

In these successive metamorphoses, we find, then, the peculiarities of three different forms of development. In the first, the Crab resembles one of the most imperfect crustaceans; in the second, it is shaped like a Lobster; in the last, it finally appears in that perfect shape which represents the highest development of crustacean life.

It would lead us too far, and weary the reader, were we to describe the structural varieties of the numerous lower crustaceans which swarm in the sea and on the shore; we will, therefore, limit ourselves to a cursory mention of their mode of life and transformations.

Many, like the cheerful Water-flea (Talitrus vulg.), and the lively Cyclops, lead a life of freedom, hop about on the strand, or disport themselves in the water: others, like the disgusting: Whale Louse (Cyanus ceti), attach themselves firmly to the larger marine animals, and devour holes in their body, or suck the juices out with greedy snout, like the Caligæ and Lernex. Just as these prefer animal food, the Chelura and 
Limnoria terebraus indulge in wood fibres, and rival the Pholas in their destructive attacks on submerged piles.
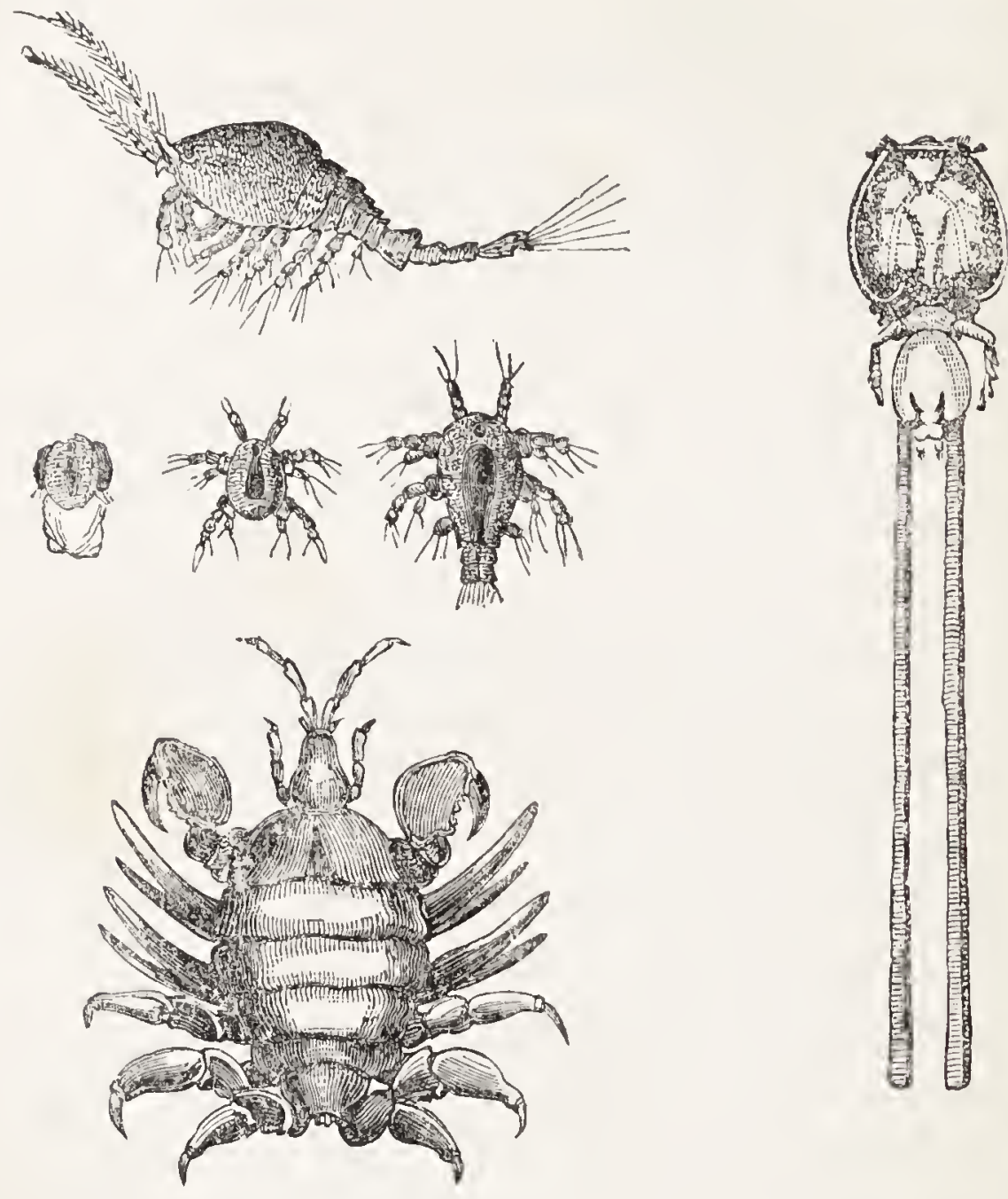

WATER-FLEAS, ETC.

What are called the Cirrhopoda, to which the Barnacle (Lepas anatifera), and the Acorn-shell (Balanus tintinnabulum) belong, have a long time troubled the naturalist; for it was not exactly known in what class they should be inserted. The former frequently attaches itself to the keel of vessels, to rocks and drift-wood: the latter is found by millions on rocks left bare by the retiring flood. The shells in which they are inclosed first led to the conjecture that they 
must belong to the molluscs; but their internal structure and development prove that they are crustaceans.

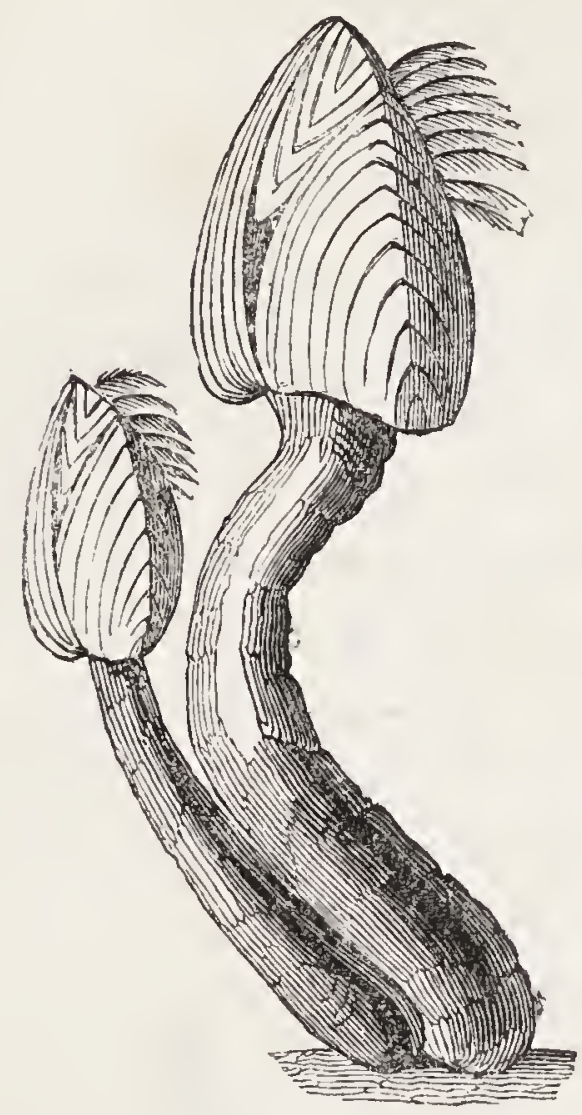

THE BARNACLE.

The almost microscopic larva of the Acorn-shell floats about by the aid of three pairs of bristly feet, wears a cuirass on its back, and has an eye in the front of the head, which makes it resemble the larva of the Cyclops. Presently, the body is enclosed in two shells, the number of feet increases, while two prehensile organs, which grow out anteriorly between the shells, allow it to attach itself to submarine objects. When once firmly attached, the migrations of the Acorn-shell are over: the now useless feet are converted into cirrhi, which can be unfolded like feathers, or drawn back by powerful muscles, and which grasp the prey floating past. 
Though these metamorphoses are remarkable enough, those of the Lernæans seem to be almost incredible.

The larva, on crawling from the egg, is a perfect crustacean; it has eyes and feet, and is somewhat later provided with a tail. All at once, the female swells enormously; two of the anterior limbs, considerably enlarged and united at the end, bore into the skin of the animal which the Lernæa has selected for its future residence; two others strengthen the mouth, which is converted into a regular syphon: all the other limbs disappear; the body swells up to a misshapen mass, and soon becomes merely an irregular sac, containing a stomach and eggs. Simultaneously the male Lernæa, which is two or three hundred-fold smaller than the female, attaches itself firmly to the latter, and seems to live at her expense, as she does from the blood of the poor fish that draws them both about.

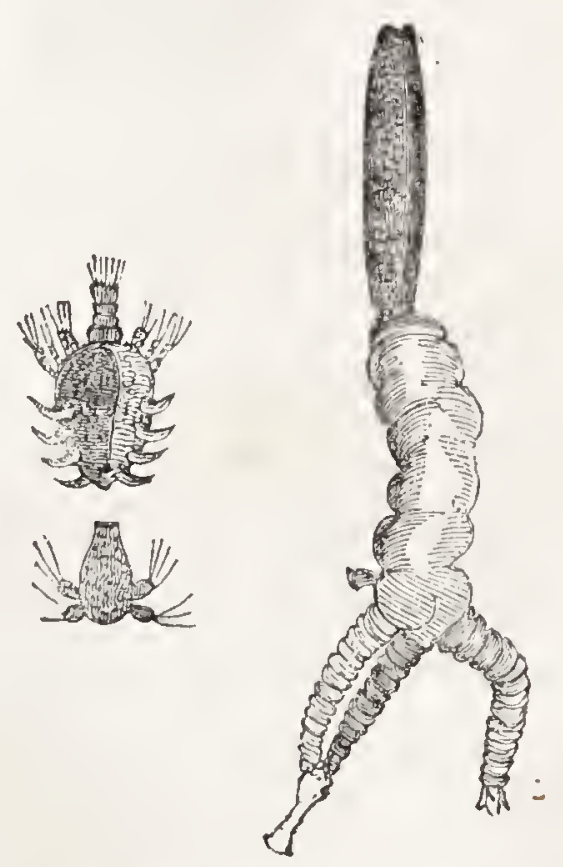

METAMORPIIOSES OF LLRNEA. 
ANNELIDS.

\section{CHAPTER VII.}

General Remarís on Annelids. - The Eunice Sanguinea. Beauty of tile Marine Annelids.-The Great Tapeworm.Food and Enemes of the Annelids. - The Tube-inhabiting ANNelids.

'THE class of Annelids, ${ }^{*}$ or ringed-worms, to which our common earth-worm and the leech of our ponds also belong, fill the seas with the majority of their varieties. All these animals are distinguished by a long worm-like shape, which is capable of great expansion and contraction. The body consists of a series of rings or segments, connected together by a common elastic covering or skin; and every joint, with the exception of the first, which forms the head, and the last, which forms the tail, resembles precisely the one before and behind, with the sole difference that the thickness of the segments gradually increases from either extremity to the centre.

The head is frequently supplied with eyes, and, more or less, perfect tentacles: in many varieties, the mouth is armed with powerful jaws or incisors. The blood is of a reddish tinge, and circulates in a perfectly enclosed system of arteries and veins.

The idea of imperfection is usually connected with that of a Worm: they are considered to be as uninteresting as they are * Annelida, or Annelides of naturalists. 
ugly, creatures; and the marvels of their organization are not suspected. But if a person wishes to form an idea of the remarkable structures of these despised animals, let him observe an Eunice Sanguinea, an annullated worm frequently found off the coast of Brittany, which at times attains the length of $2 \frac{1}{2}$ feet. The whole body is divided into minute segments, and consists of about 300 rings.

A brain, and 300 secondary nervous centres and ganglia, from which some 3,000 nerves emanate, regulate the movements and vegetative functions of the Eunice; 280 stomachs digest its food; 500 galls refresh its blood; 600 hearts diffuse this sap of life through the body; 30,000 muscles obey its will and produce the snake-like motion. What an astounding richness of organs! What an extravagant equipment! Here is truly no reason to sympathise with penury, or gird at poverty.

As regards their external appearance, many of these marine Annelids are among the most glorious creatures of the animal
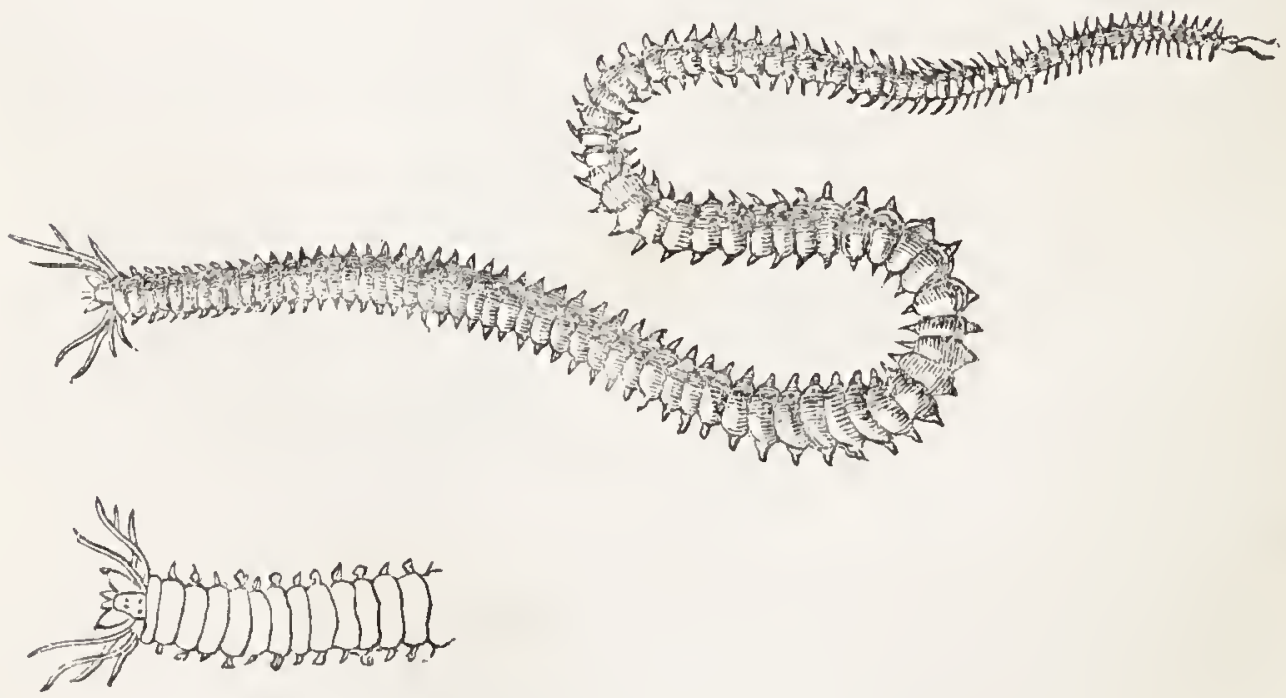

EUNICE SANGUINEA. 
world. The rainbow-tints of the humming-bird, and the glistening metallic lustre of the richly ornamented beetles, are found here again. Most distinguished for beauty are those varieties which live in freedom, which crawl with a serpentine motion through the fissures of the rocks, or move along the bed of the sea, in the sand or slime. The delighted naturalists have hence bestowed on them the sweetest names of the Pagan Mythology: Nereïs, Euphrosyne, Eunice, Alciopa, Aphrodite. "No longer call the violet the emblem of modesty;" De Quatrefage exclaims, with great enthusiasm. "Sooner look at our Annelids-what else do they require to dazzle the eye? And yet they timidly retreat from our gaze; and only a few persons know the secret marvels which are concealed under the weed-covered rocks, or in the sand of the ocean bed."

In the majority of the free Annelids, each segment is provided with variously formed pairs of appendices, which serve for change of place or defence.

They have usually bristled feet; more frequently we can trace on each segment, or on a certain number of the central rings, laminated gills, which resemble the most lovely plumes. In other instances, the feet are merely indicated by a few bristles; and no trace of an external limb is visible on the whole bodies of others. Here, the less perfect animals respire through the entire nude surface of their bodies. The Giant Tape-worin (Nemertes gigas) gives us a remarkable instance of this stoppage of development. It grows to a length of thirty to forty feet, and about half an inch in width; is pressed flat like a ribbon, of brown or violet colour, and shines like polished leather. Under loose stones, or in portions of the rock, this gigantic worm ties itself up in thousands of apparently 
inextricable knots, which it ties and unties by the contraction of its muscles. It lives on Anomix (small shell-fish, which attach themselves to submarine bodies). When it has swallowed all the animals of this description in its reach, or desires to change its abode for any other reason, it extends straight before it a long, dark ribbon, at the end of which is a head bearing some resemblance to that of a snake, but not possessing the large mouth or terrible teeth. The naked eye detects no contraction of the muscles, no apparent cause for this movement; the microscope alone will show us, that the Nemertes glides through the water by the aid of extremely delicate oscillating cilia, which cover the entire surface of its body. It hesitates for some time, till at last it discovers a stone that suits it some fifteen or twenty paces off. Then, it unrolls itself slowly, to remove to the new refuge; and as the entanglement is undone here, it begins again there. In this animal, all the apparatus for existing is simplified as much as possible. The rnouth is a hardly visible circular orifice; and the intestinal canal terminates in a blind sac.

Not in vain has nature provided the majority of the more perfect Annelids with the sharp bristles which she has denied the Nemertes and the burrowing Lug-worm (Arenicola piscatorum), which fishermen so often employ for bait. They all feed on living animals, crustaceans, planarians, and other small creatures, which they surround, and pierce with their terrible weapons. Some, lying in ambush, watch for the passing prey, which they seize with their snout, and stifle in in their deadly embrace; others, of a more lively nature, pursue them in the sand, or in the thicket of corallines, nullipores, and other marine plants. Fish live in a constant state 
with its requirements? Hence, the bristly feet and lateral respiratory annexes are absent; for though they are so useful to the free Annelid, they would serve no purpose here. On the other hand, the head is provided with a wondrously beautiful crown of feathery gill-plates, which serve both for respiration, and for seizing the prey as it swims past.

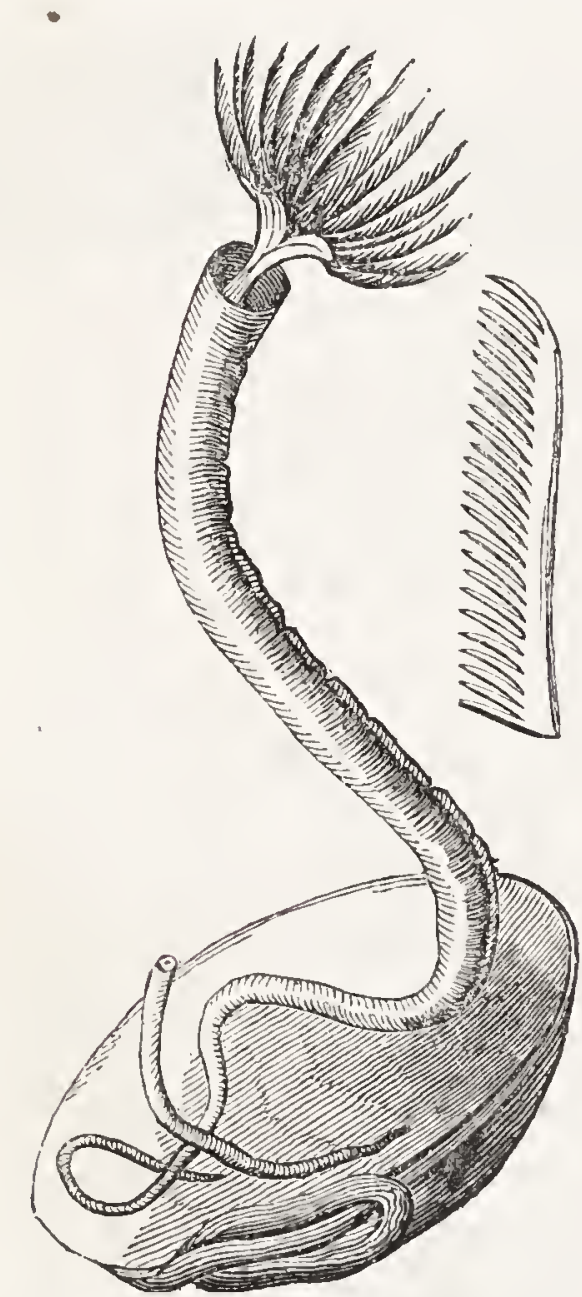

SERPULA TUBICOLA.

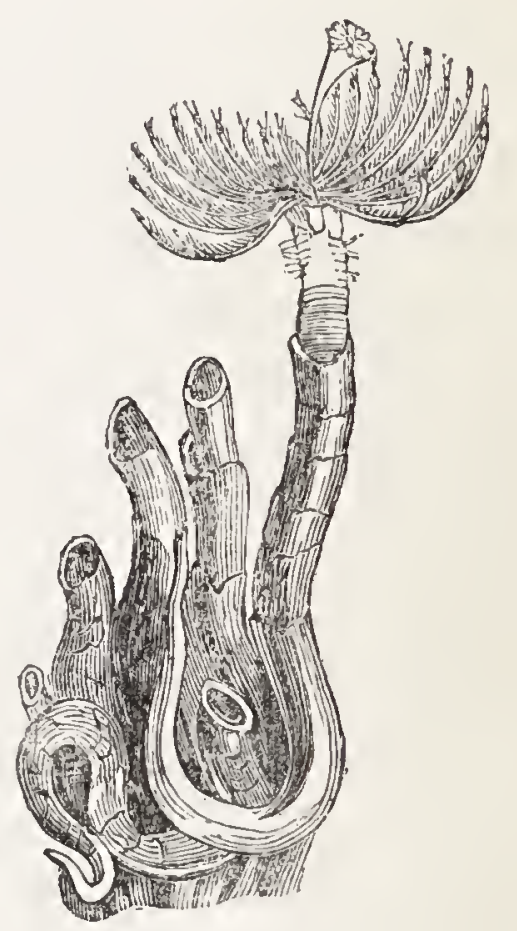

SABELLA ALVEOLATA.

Perfectly closed at the posterior end, the tube in front has a round orifice, the only window through which our hermits cast a glance on the surrounding world, procure their food, and expose their blood to the reviving influence of the water. Hence, 
call the Tubicola neither curious nor vain, if you see it with its richly decorated head constantly thrust out; and only feel glad, that this habit, caused by necessity, affords you the opportunity to study its wondrous form. Place in a vase filled with salt water, a stone, or an old mussel-shell on which serpulæ and cymospiræ have taken up their abode, and soon you will see, how a little round lid cautiously rises in that tube, which it has hitherto hermetically closed, and forbidden you to gaze into. It is the door of the house opening; and the animal will soon make its appearance. Under this lid, you now notice bodies like buds: here, dark violet or crimson there, olive or orange; further on, tinged with all these colours. See, how they grow, become gradually unfolded, and expand their brilliant branches. They are real flowers, but far more perfect than those which adorn your garden; for they are gifted with feeling, and free will. At the slightest blow or disturbance of the water, the brilliant plumes are drawn in, and disappear like lightning in the tube.

But not all the tubicolous Annelids have such perfect caves as those just described. Many are contented with forming sand or small pieces of shell into cylind́rical tubes. But even in these productions of the Terebellæ, Sabellæ, Amphitrites, etc., there is revealed an admirable art, a regularity and perfection, which causes us amazement. These graceful sandtubes, which are frequently found on the strand under the marine plants thrown up by the sea, serpulariæ and mollusc shells, are composed of grains of nearly equal size, so artistically glued together, that the delicate walls have always an equal thickness. The form is cylindrical, or, rather, funnelshaped, as it gradually grows under from the bottom. Some 
of these Tubicolx live like hermits; others prefer society, as, for instance, the Fan-worm (Sabella alveolata), which forms reticulated masses of grains of sand, and attaches them to rocks at the edge of the lowest ebb-tide. Frequently, a long stretch is entirely covered with these connected tubes. When the water retires, nothing is seen but the closed openings, in which a drop of water usually remains; but as soon as the tide rises, the sandy tube is converted into a glorious picture, glowing with every hue of the rainbow. 
MOLLUSCS.

\section{CHAPTER VIII.}

Molluscs generally.-The Nudibranchs.-The Cephalopods. Their Structure. - Strange Peculiarities of their Shin.D'Orbigny's resisting Apfaratus. - Immense number of Cephalopods.-Their Voracity.-Their Enemies.--Their Value to Man.-Marvellous Size of some Cephalopods.-Tie Kraken.-The Argonatt.-The Nautilus.-Great Rarity of the Animal.-The Cephalopods of the Primaval Ocean.

Gasteropods.-Their Organs of Respiration .-Their Beadty.Their Movements.-Their Metamorphoses.-The Sea Hare.The Carinaria.-The Patelle.-The Haliotids.-The Spifal Conchylia. - Their Varietr and Beauty.-High Prices paid for some Varieties.-Movement of the Gasteropods.-The Ianthines.-Abode of the Marine Snails.-On what do they feed?-Their Enemies.-Their Valde to Man.

Pteropods.-Their Structure and Mode of Life.

Acephala or Lamelli-mranchiates.-General Remaris on their Structure .-Pholades.-Food of the Acephala.-Their Numerous Enemies.-The Mussel.-Its Artificat Breeding.-The Oyster.-Orster Beds Made by the Romans.-Oyster Breeding in tile lago di Fusaro.- Pearl Fishery in Ceylon.-How are Pearls formed?-The Spondylus Regius. - The Giant Mussel.

Brachiopods.-The Salp $2 .-$ Their extraordinary Alternations of Generations.-Chamisso.

THE great group of Molluscs or soft animals to which Conchylia, Snails, and Cuttle-fish belong, is distinguished by the following main characteristics. 
Their soft body is covered by a flexible, contractile skin, or what is called the mantle, beneath which are horny or calcareous shells. Their most important organs are double and symmetrical, and their arrangement is usually so regulated that the mouth is close to the opposite orifice.

The blood is white and maintained in perfect circulation. The arterial blood flows from the heart into all parts of the body, then returns through the veins to the respiratory apparatus, and, after boing exposed to the effect of the air, flows back to the heart. All aqueous molluscs breathe through gills. 'Their nervous system consists of ganglia, connected together, which form a double row round the alimentary canal.

They are distinguished from fish by the absence of an internal skeleton and vertebra, as well as by the great variation of their organs of respiration and motion.

The Molluscs, according to Cuvier, are divided into five classes;-1. Cephalopoda (with arms projecting from the head) ; 2. Gasteropoda (that crawl on the ventral surface); 3. Pteropoda (with feet resembling wings); 4. Acephala (headless animals); and 5. BrachIopoda (with feet resembling arms), which differ materially from each other both in structure and habits, so that the most perfect among them are closely allied to the vertebrated animals, while the lowest are hardly higher in organization than the Polypes.

Hence, to avoid any confusion, we will describe each of these classes with their peculiarities.

The Cephalopods are formed of two halves, evidently divided from each other; the body, which, in the shape of a sac anteriorly open, contains the gills and digestive organs; and the well 
developed head, with two sharp eyes, and crowned with tentacles or feet. The animal owes its name to this remarkable form; for, as the feet extend round the head, it walks or crawls on its head in the strictest sense of the term.

All Cephalopods are aquatic animals and breathe through gills. These organs are concealed beneath the mouth, in a separate cavity, whose valves extend and contract alternately,

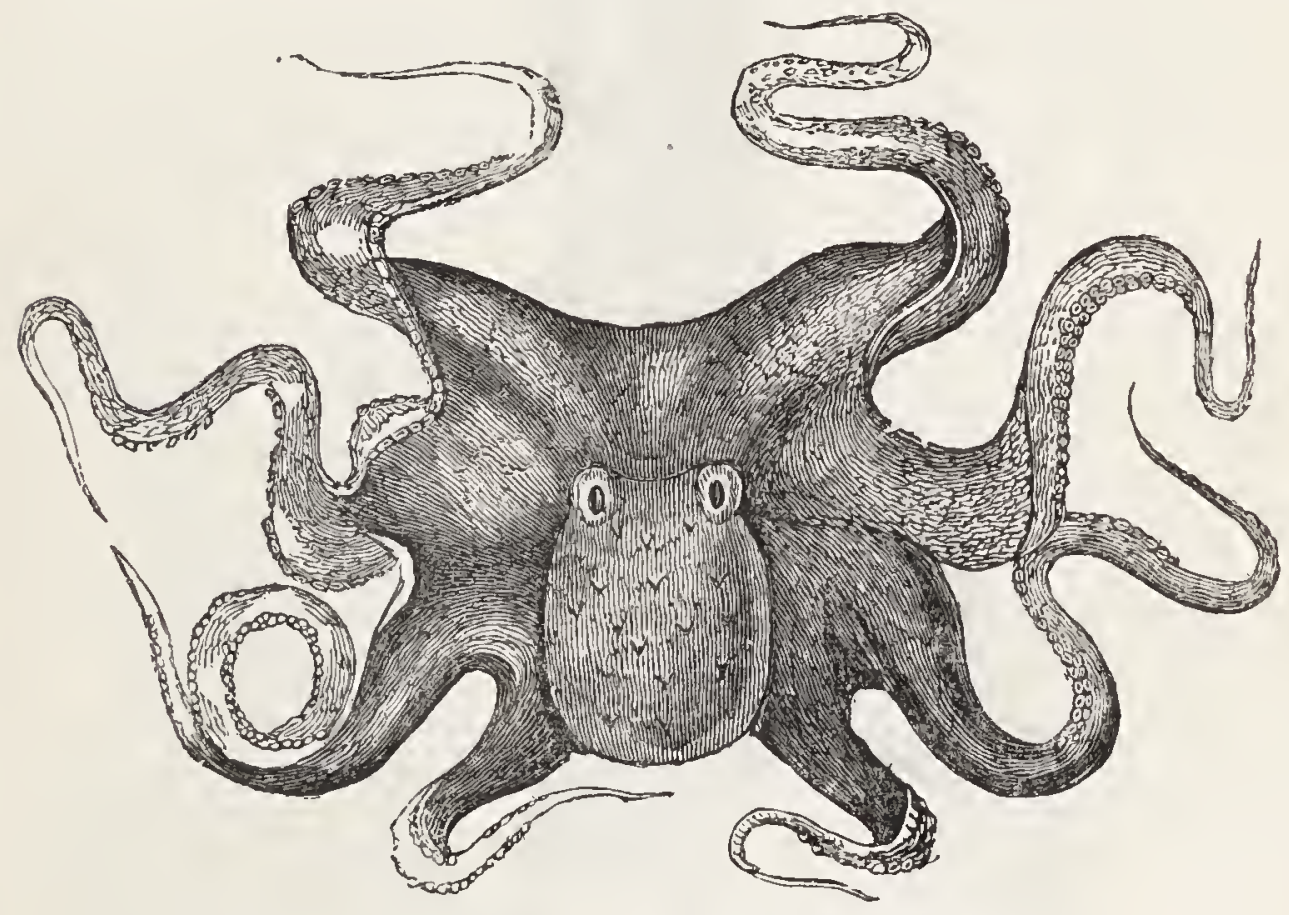

TIIE CEPHALOPOD.

and which is connected with the external world by means of two orifices. The one serves to receive water, the other, which is elongated into a tube, to expel it again.

The varying number of gills is characteristic of the two natural groups into which the Cephalopods fall.

The Acetabuliferæ, or Suckers, to which the Octopods, Argonauts, Kalmars, Sepiæ, Sepiola, etc., belong, and which comprise, the majority, have only two gills, while the Tentaculiferæ, 
which are only represented by two varieties of Nautilus in the present creation, have four, two on either side.

According to the number of these tentacles or feet, (for these curious organs serve both for motion and seizing food) the

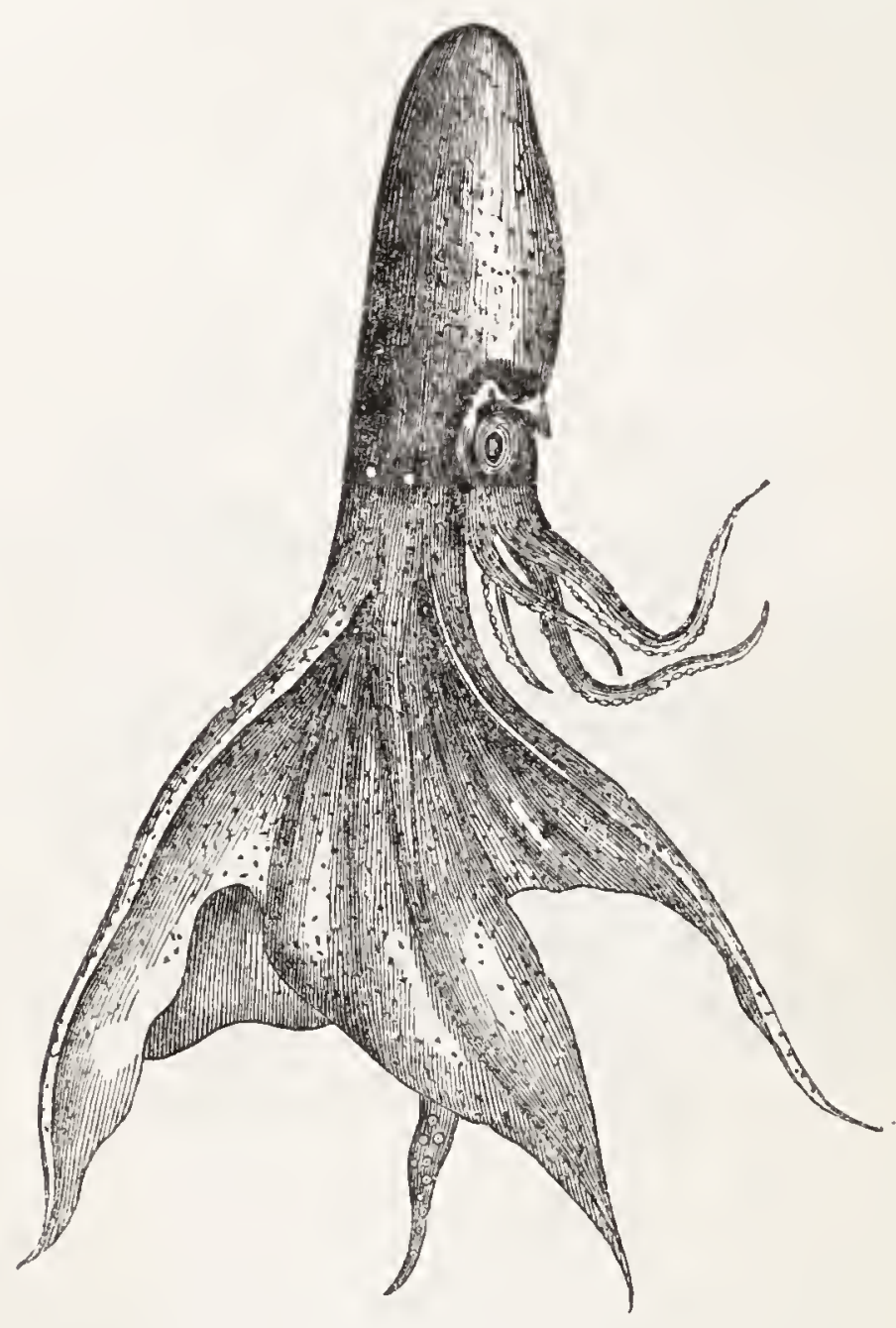

THE ACETABULIFERA.

Acetabuliferæ are subdivided into Octopods, which have only sessile arms; and the Decapods, in which two of them are elongated into feelers. The tentacles are internally provided with cups, which are closely attached and mounted on stalks. With their fixed cups or suckers the Octopods attach themselves so closely to objects, that it is impossible for the 
prey, when once captured, to escape from the murderous embrace.

Although the Decapods, with their stalked suckers, can

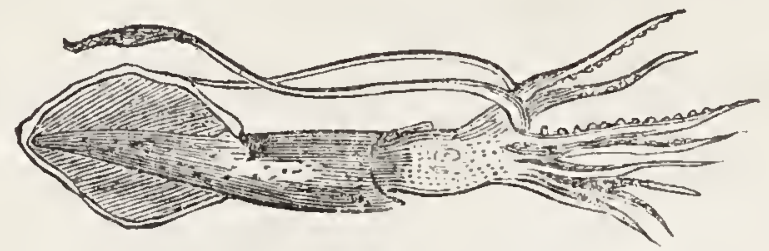

LOLIGO VULGARIS.

neither suck fast nor form a vacuum, in exchange for the these organs they are provided with sharp claws, which are

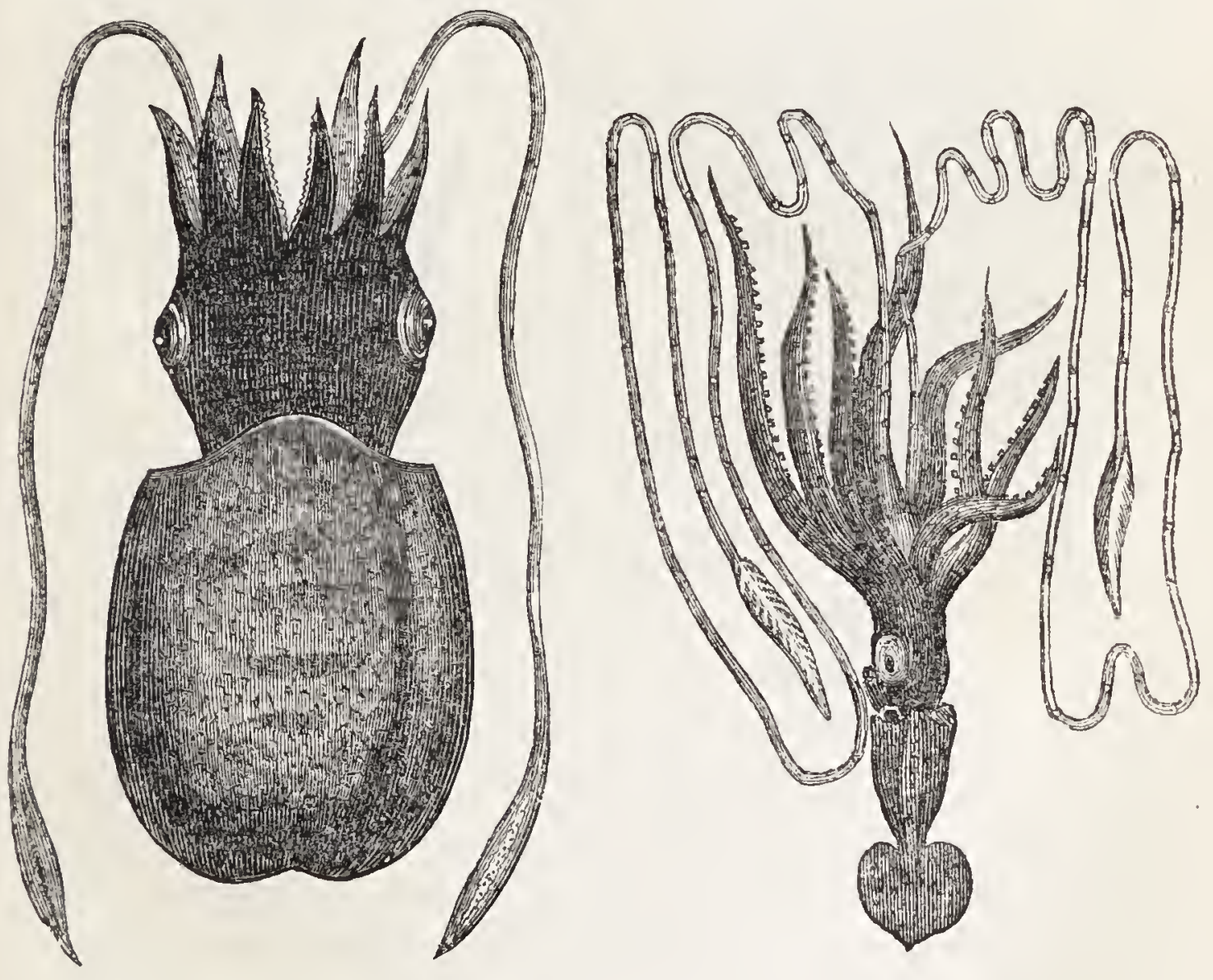

KALMAR AND SEPIA.

very useful, as they can turn on their stalk in every direction. By an admirable precaution of nature, this animal, like the 
cat, can draw in or thrust forward its hooks at pleasure, and hence in its retrograde movements it need not fear that it will entangle itself anywhere. The proportionate size of the tentacles and the arrangement of the suckers are very irregular in the several varieties, of which we will give some examples. While in the common Octopod the feet are nearly all of the

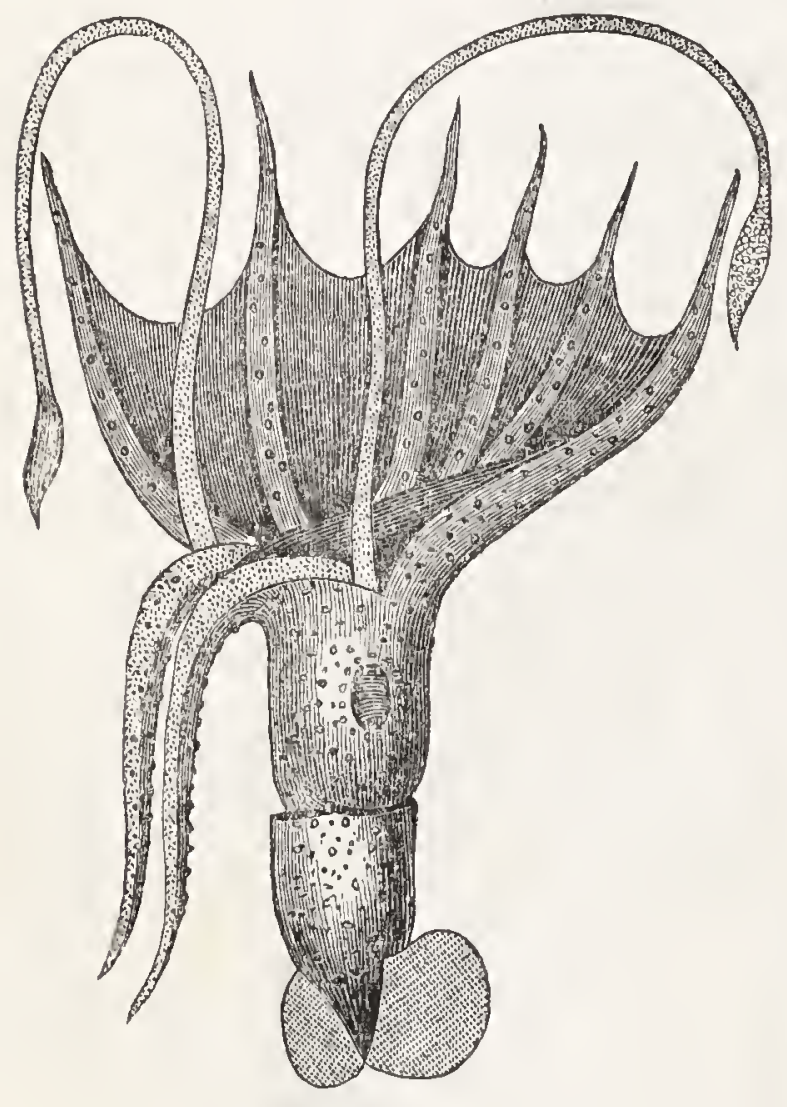

DECA FOD.

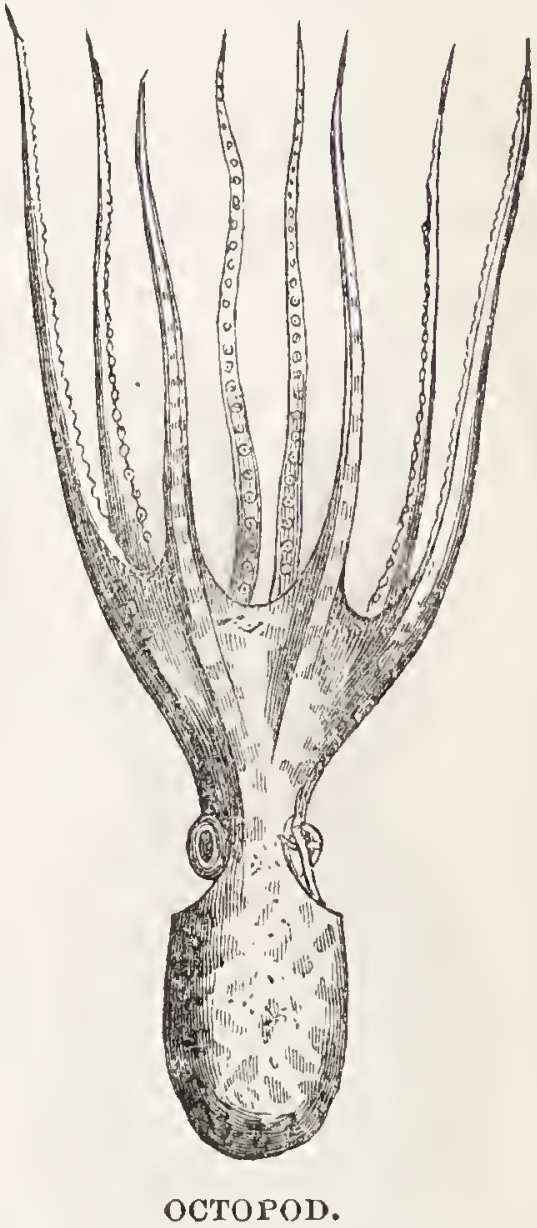

same length, the Philonexis has four long and four short; and in the Argonauts two of the eight arms have a sail-like expansion at the end. In the Kalmars and Sepix the tentacles are considerably elongated, and in the Chiroteuthæ this disproportion is so great, that these organs are at least six-fold larger than the entire body. 
In those varieties which pass a local, crawling life, and, attaching themselves to a stone, seize the passing prey, the tentacles, to meet the case, are always longer, more fleshy, and stronger than in the swimming Decapods.

In some, we find the arms divided; in others, connected by a membrane. The Octopod has on each arm a double row of suckers; the Sepia, four; the Eledone only one. Such strange variations does nature play on one theme; such inexhaustible variety does she develop in the formation of a class of animals, which yet are all built on the same fundamental plan.

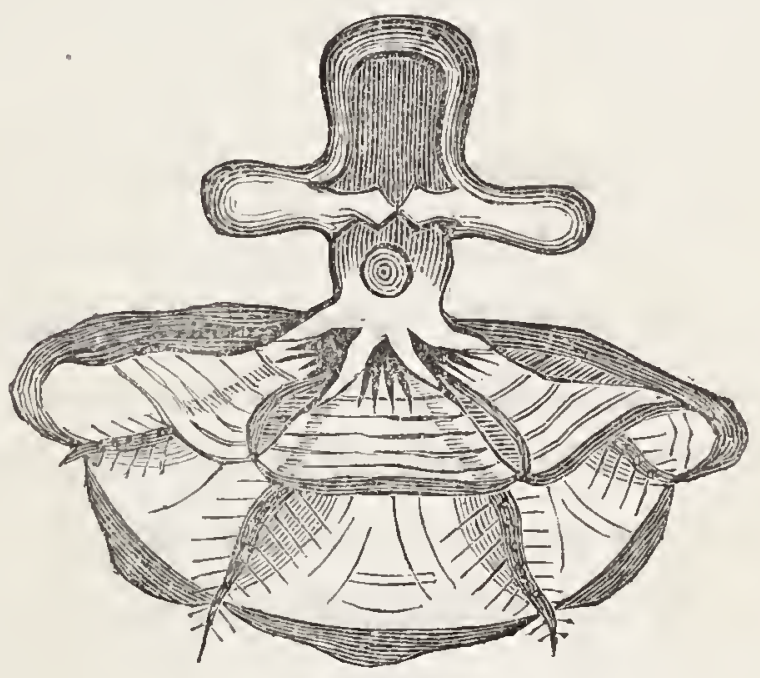

THE ELEDONE.

If the Cephalopod has, by means of its suckers or hooks, caught a fish or crustacean, the unlucky being is immediately conveyed to the mouth, and mercilessly champed by two horny or calcareous jaws, which move perpendicularly against each other, like the mandibles of a bird's bill.

In addition to the feet, by whose aid the Cephalopods crawl along the bed of the sea, or steer themselves when swimming, the violent expulsion of the water through their syphon aids 
them in their retrograde motion. In some varieties, which have a large, long, and narrowly-formed body, and proportionally powerful muscles, this is performed with such violence, that they shoot like arrows through the water; and, at times, form a curve through the air like the flying-fish. Thus, Sir James Ross tells us, that, on one occasion, not only did such a number of Cuttlefish bound on the deck of his vessel, which was sixteen feet above the water, - so that more than fifty were captured, - but some actually cleared the other bulwark, and flew right over the ship.

Finally, in those Decapods which pass their life in swimming, the motion is favoured by a fin-like extension of the mantle. This, in the Sepia, runs laterally along the whole body; while, in the Kalmar, it is at the extremity.

The skin of the Cephalopods offers a few very strange peculiarities. It is, namely, covered with different-coloured spots, which, so long as the animal is in a state of tranquillity, are almost imperceptible; but, if it be irritated in any way, they grow six times as large, and then appear and disappear again with the utmost rapidity, by alternate contraction and expansion, so that the same Cephalopod is at one moment white and directly after brown or yellow. It is difficult to say what benefit it derives from this change of colour; it is possible, though, that it can startle some of its enemies by it. 'The surface of the skin, also, changes according to the temper of the creature. When the Octopod is resting quietly, for instance, it is found to be perfectly smooth; but when excited, the body, head, and even arms, are covered with tubercles and lumps, though a moment before nothing of the sort could be seen. 
Who could have expected such a nervous system and sensibility in the cold-blooded Molluses?

It might be supposed, that the Cephalopods were already sufficiently provided with offensive and defensive weapons in their speed, their arms, and their powerful bill; but nature has endowed the majority of them with a curious organ of secretion, which produces a black juice, ejected through the syphon. When the animal is in danger, it shoots out a sufficient quantity of this inky fluid to form a dense cloud in the water, and conceals itself thus from its enemies. The black Cuttle-fish liquid is employed as a dye. The permanency of the pigment may be proved by the fact, that the contents of the ink-bag in fossile sepiæ has been found fit for use. It is considered a great curiosity, that grains of wheat, which were buried with Egyptian Mummies some thirty centuries ago, should not have lost their germinating power; but that an animal secretion, whose origin dates back to the most remote epoch, should remain unchanged, is certainly far more astounding.

A mong the greatest curiosities of the Cephalopodic organism, the resisting apparatus, discovered by D'Orbigny, must also be reckoned. As, namely, the head and body of the Cephalopods are, internally, only slightly connected, the animal could hardly endure any rapid motion, were not the mutual connection of these parts provided for in a different way. Wondrously provident nature has supplied the inner wall of the mouth on each side with a button-like elevation, which fits into a suitable gutter or cavity on the lower end of the head; so that the animal can button up or unbutton the parts, or, in other words, render their connection tighter or looser, as it pleases. 
By a permanent tight attachment of the head to the body, the animal would, however, have lost a great portion of its mobility, and, consequently, of its ability to secure food.

Countless numbers of Cephalopods are scattered over the entire ocean. Some varieties, like the Argonants, always remain out at sea; while others, like the common Octopod, exclusively inhabit the coasts, where, concealed in fissures of the rock, they attach themselves by one portion of their arms, and fish with the other. The Oceanic Cephalopods (Ommas. trephes giganteus and sagittatus) annually leave, the first the South, the second the North, Polar Sea, and migrate in enormous ranks to the coast of Chili and Newfoundland. The Sepias and Kalmars appear in the spring in large swarms off land, remain there a shorter or longer period, according to the variety, and then return to deep water.

Nearly all the Cephalopods are nocturnal or crepuscular animals. At night, they swarm on the surface of the water; while, by day, they are not visible. With the exception of the Octopod, which passes a solitary life on rocky shores, they are gregarious, and wander about in large schools.

All are frightfully predatory; in the shallows and banks, they ruin the hopes of the fishermen; out at sea, they swallow myriads of young fish, and Nudibranch Molluscs; and, like the tiger, kill not merely to satisfy hunger, but through pure ferocity. D’Orbigny saw a Kalmar, which was left by the tide among a parcel of young fish, institute a terrible butchery, without eating them.

The equilibrium of the sea would soon cease, if the ranks of the Cephalopods were not continually worried by a large number of enemies. The cachalots and dolphins live almost 
entirely on them; and so soon as they come to the surface after sunset, they are pounced upon by albatrosses and stormbirds.

At various localities, they serve as the exclusive food of tunnies, bonitas, and many other fish, as an examination of the stomach proves. The cod destroys an extraordinary number, which appear with it annually on the coast of North America and the bank of Newfoundland; and, as a bait for this valuable fish, men capture millions on millions, so that they play a considerable part in one of the most valuable branches of trade among the great seafaring nations. In other respects they are useful to man. Among the ancient Greeks, the Octopods, Sepias, and Kalmars (Loligo), were an esteemed article of food; and large numbers, either fresh or dried, are still eaten by the dwellers on the coasts of the Adriatic and Mediterranean, as well as by the Biscayan and North French fishermen. At Teneriffe, Brazil, Chili, Peru, India and China, they are a staple article of food. In Japan, a very considerable trade in them is carried on. The inner shell of the Sepias (cuttle-bone) is employed by goldsmiths for polishing, and we have already alluded to the use of the dye.

From the great number of their powerful and rapacious enemies, we can form an idea of the importance of the Cephalopods in the chain of maritime existence, and come to the conclusion that animals, which are so incessantly pursued, must necessarily be largely propagated. Their numerous eggs are usually laid in the spring, among those sorts which inhabit deep water; they float freely on the surface of the ocean, left to the currents and the winds, and form large gelatinous bunches of cylindrical rolls, often as large and long as a man's 
leg. The eggs of the Cephalopods living off the coast appear in the form of small transparent clusters, or black pear-

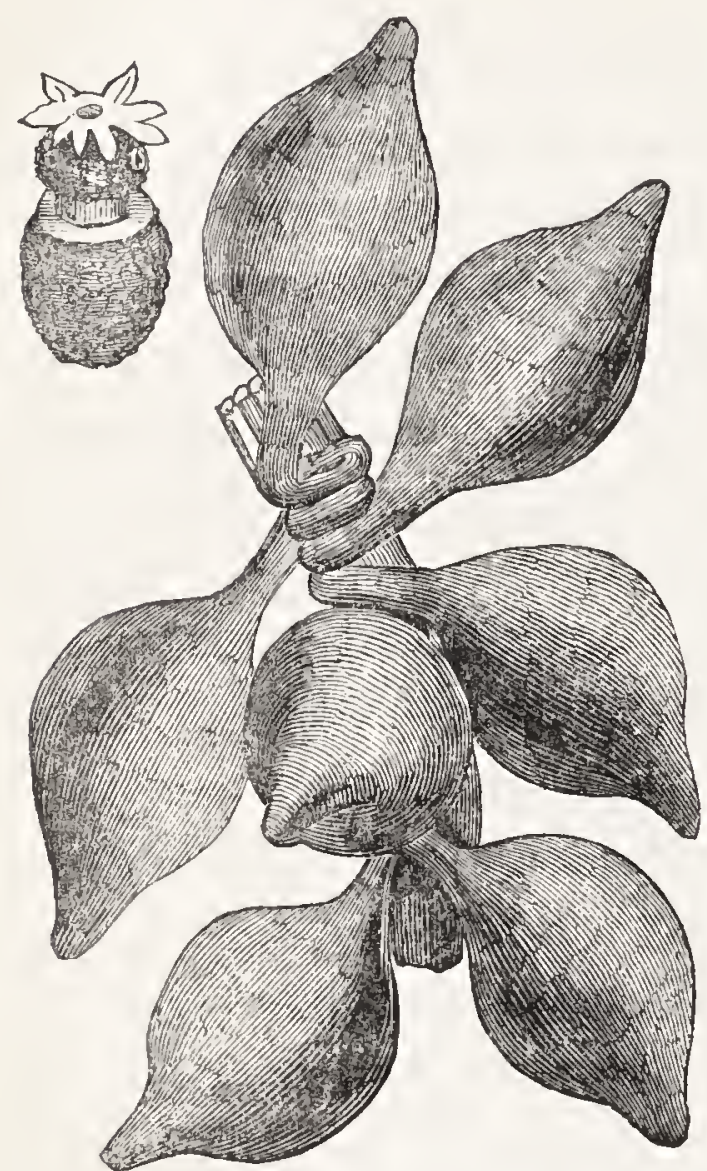

CUTTLEFISH EGGS.

shaped bags, whose stalks are fastened to sea-weed or some other fixed object. In some varieties, they are fastened along the edge of a glutinous band. They are not incubated by the mother, as the ancients believed; for no coldblooded animal possesses that power. The sun is here again the great worker of life. The young fry come unto the daylight perfectly formed, and at once display their gregariousness, for they burst the shell almost simultaneously and swim about together.

According to credible reports, some of the Cephalopods attain an extraordinary size. Thus, Péron saw, near Van Diemen's Land, and no great distance from the ship, a Sepia as large as a barrel, heavily 'rolling on the waves. Its colossal arms moved like huge snakes on the surface of the water. Each of these organs was at least six to seven feet long, with a diameter at the base of eight inches.

Quoy and Gaymard make the following statement:- "In the Atlantic Ocean, near the equator, and in perfectly calm weather, we found the relics of a monster Kalmar, that the 
crabs and sharks had left, weighed close on a hundred pounds, and was only half the body, completely stripped of the arms, so that the entire animal must have weighed at least $200 \mathrm{lbs}$. How large and powerful must its arms have been? Imagine an Octopod of equal size, in which the tentacles are far larger; and it would seem perfectly credible that such a fearful mollusc could drag a man out of a boat."

"It is indubitable," D'Orbigny says, "that in all seas there. are very large Cephalopods, which science is not yet acquainted with. The rare appearance of these colossal individuals proves that the lower zones of the sea contain a quantity of animals of an entirely new form."

Still, we must not, because some gigantic Cephalopods have been really seen by truthful and sensible men, believe all the exaggerations and fables about this creature which have been ever told by naturalists. Thus, Montfort speaks of a colossal Octopod which overturned a three-master; and Pernetti, of a similar one, which, by climbing up the rigging, upset by its weight a large vessel.

Schwediaux mentions a Cachalot, in whose jaw whalers found the fragment of a Sepia near 25 feet long; and Pennant describes a gigantic Cuttle-fish, whose body had a diameter of 12 feet, and whose arms were 54 feet in length.

In Pliny, we read of a monster of this description, which used to land at Carteia, on the Spanish coast, at night, to plunder the fish-ponds. After many vain pursuits, it was at length surprised by the dogs, which summoned the guards by their barking. After an obstinate fight, they succeeded in killing the snorting monster, which fought with its arms as with clubs. The head, which contained 15 amphoræ (of 24 
pints), was sent to the Proconsul Lucullus as a great curiosity, as well as the arms, which were 30 feet in length, and could hardly be held by both arms. The entire animal weighed 700 pounds.

A more recent French naturalist most solemnly ascribes the loss of the man-of-war, the "Ville de Paris," which sank with nine other vessels that proceeded to its help, not to the storm but a band of colossal Cuttle-fish! But all these exaggerations, strange as they are, appear like every-day stories when compared with the Norwegian Kraken. 'This is described to us as a Cephalopod, which measures at least a mile in diameter. The back is covered with a perfect thicket of sea-weeds and corals. When the Kraken rises to the surface, it raises its mast-like arms in the air, and, after enjoying the divine light for some time, it sinks slowly again to the bed of the ocean. At times sailors have landed on a Kraken, and lighted a fire on the supposed reef. But it did not please the Kraken to have burning coals on its back, and thus it came that the treacherous soil immediately sank beneath the deceived ones, and dragged them down into the abyss. "Thus the oriental fable of "Sinbad the Sailor" is repeated in the legends of the North. Even Linnæus, in his first edition of his "System of Nature," introduced the Kraken under the name "Sepia Microcosmus;" but he afterwards removed it from the list of living beings. Requiescat in pace!

In all the Acetabuliferæ the body is naked; and the Paperboat (Argonauta argo) is alone contained in a fragile shell.

Old and more modern poets have repeatedly sung the voyages of the Argonaut, which, by its example, first led man to the idea of navigation, with its two arms spread out in a 
fin-like shape for sails, the six others paddling in the water; the keel of its graceful shell furrows the surface of the placid ocean. But so soon as a breath of wind ripples the sea, or the slightest danger is apparent, it lowers its sails, draws in its rudder, crawls into its shell, and sinks immediately into deeper water. Unfortunately, there is no truth in this pleasant story. Like the commonest Cephalopod, the Argonaut crawls about on the bed of the sea; but when it swims, which it certainly does like the majority of its relations, with great speed, it lays its sail-like tentacles close to the shell, strikes out the others straight before it, and forcing the water through its syphon tube, shoots backwards through the sea. As it is quite loose in its shell, many naturalists believed that it was a parasite, which, after killing the right owner, took possession of it in the same way as the Hermit-crab. It has, however, been satisfactorily proved that this is not the case, for it can reproduce its shell if injured, and the young reveal traces of the shell in the egg. There are varieties of the Argonaut in the Indian Ocean and the Mediterranean.

The Nautili, which also live in an external shell, are Cephalopods of a very peculiar description. Here the huge arms provided with suckers disappear, and a large mass of contractile fine tentacles is substituted for them. The handsome pearly, spiral shell is divided into a large number of chambers by partition walls, which have a funnel-shaped hole through the centre. In the first and most spacious of these chambers the Nautilus dwells; but it sends a tube of communication through all the holes in the partition walls to the extreme end of the spiral shell. The use of this syphon and the numerous chambers is still but little known, and this probably is pro- 
duced by the great rarity of the animal. Although the empty shell is often found off the Moluccas, on the coast of New Guinea, and elsewhere in the Indian Ocean, swimming on the

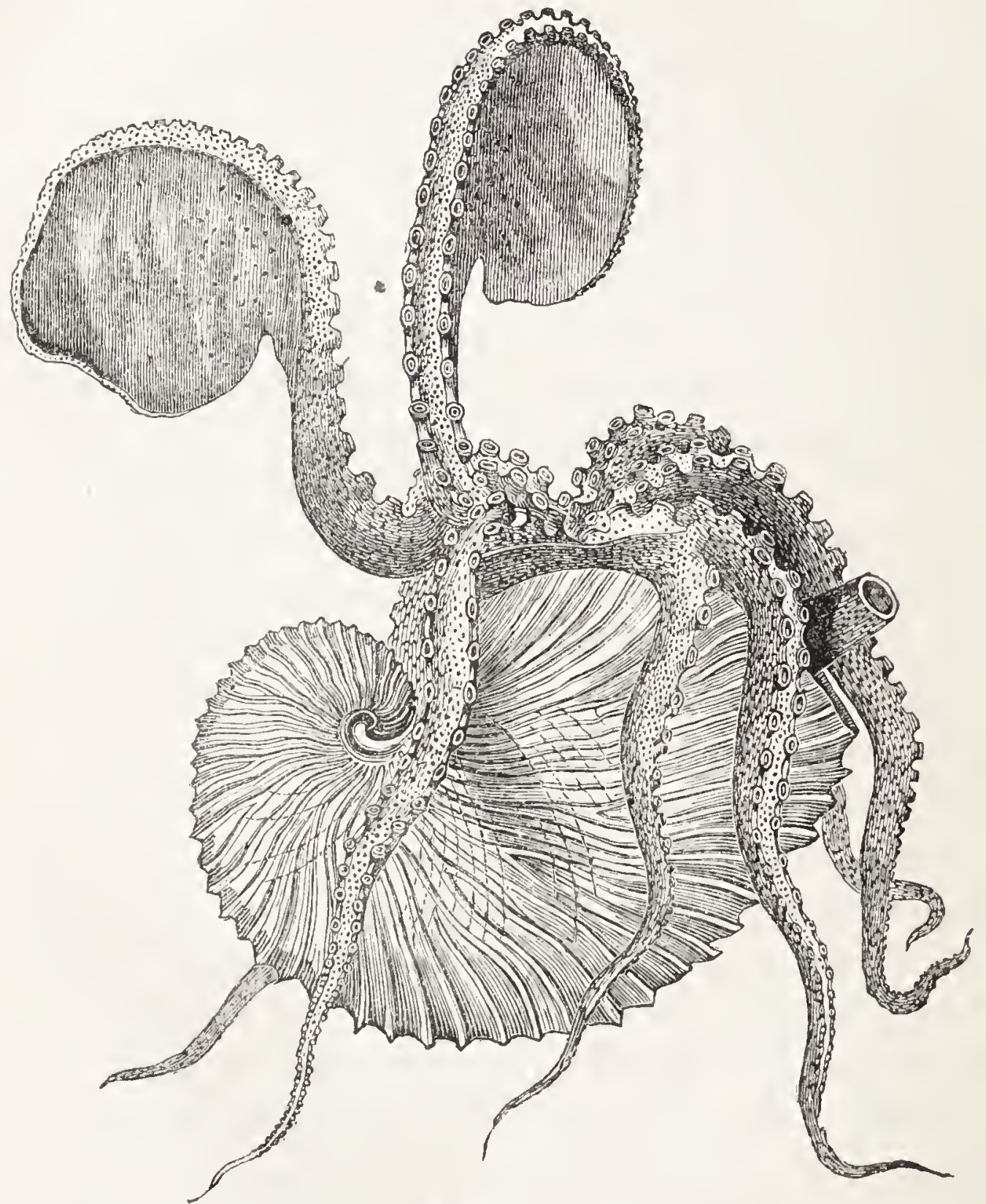

THE NAUTILUS.

sea or tossed ashore, Dumont D'Urville, in spite of all his trouble and promises, could not obtain a single living specimen from the Islanders. At a later date, his wishes were satisfied 
by the kindness of the Viceroy of the Moluccas. The Nautili doubtlessly live at a great depth, and hence come very rarely into our possession.

What, however, renders these animals specially interesting is the fact, that they are the only living representatives of a race which once occupied the bed of the primeval ocean, and whose fossil remains offer the naturalist a series of historic plates, by which he can recognise the great age of our planet. What are the ruins three or four thousand years' old, which evince the former grandeur of nations that have died out, when compared with these medals of the creation, each of which carries us back for millions of years!

Cephalopods with straight or curved, many-chambered cells, separated by unbored partition walls, appear among the earliest animals that populated the globe. The Silurian strata reveal to us several specimens; but these first species soon disappear from the scene, and their place is supplied in the Devonian strata by others, which again yield to later families in the coal formation, where the Goniatites attain their greatest specific development.

With the coal formation, the Orthoceræ, Cyrthoceræ and Phragmoceræ disappear; and of all the Cephalopods then existing only the Nautili remain, to which Ammonites are joined in the Trias group. These first Ammonites have most peculiar partition-walls, very different from those of the upper strata. With the Trias, the Cephalopods living at that period disappear in their turn, and their place is taken in the Jurassic formation that covers them, by a large quantity of perfectly new varieties. Amid new Nautilidæ, appear many conical Be'emnites, and numerous Ammonites with serrated partition- 
walls of wondrous diversities of shape. They covered all the seas with their frequently gigantic varieties, anything like which the present period of creation cannot display, although at that time they formed perfect strata.

If we now ascend from the Jurassic strata to the chalk, we find another metamorphosis: not only Ammonites, decorated externally with bosses, or Belemnites, but perfectly new generic types make their appearance. With the progressive chalk formation repeated changes occur. Ammonites, with thorny excrescences on the sides of the back, are found, and the Belemnites have only a single representative.

With the first strata of the Chloritic chalk, the Fauna again undergoes a change: the numerical proportion of the varieties no longer remains equal, and the entire zoology undergoes a change. When they had attained their greatest development the Cephalopods gradually disappeared and entirely cease with the white chalk, where the last specimen of the Belemnites is also found.

The latest tertiary formations only produce a few Cephalopods. We find none of the enormous straight or curved shells of the oldest strata; none of the graceful spiral Ammonites of the Jura and the chalk. In this new lustre of our planet, only Nautili, Sepias, Beloptera and Spirulirostra appear as the representatives of these varying Fauna of the lower strata, or new varieties make their appearance which come down to our time. If we turn a glance from this long succession of extinct forms to the now existing Cephalopods with chambered shells, we find them limited to three living representatives, two Nautili and a Spirula, while the naked Cephalopods play a very important part in the ocean of to-day. 
Some of these animals existed at the time of the Jurassic formation, and can boast a long descent, while others are only known to us in a living state, and are probably parvenus of our æra.

With reference to corporeal development, the GaSTEROPODS or snails rank among the Molluscs next to the Cephalopods. They also possess a head equally distinguishable from the rest of the body, to which two brilliant black eyes, which, in the majority of the families inhabiting the sea, are attached to stalks projecting from the base of the feelers or horns, give a lively physiognomic expression.

Still, their nervous system is less fully developed, and while the Cephalopods, by the help of their arms and syphon, swim rapidly, and can seize even a distant prey with facility, all the Gasteropods crawl slowly and cautiously on a fleshy disc projecting under the organs of digestion, to which they owe their name.

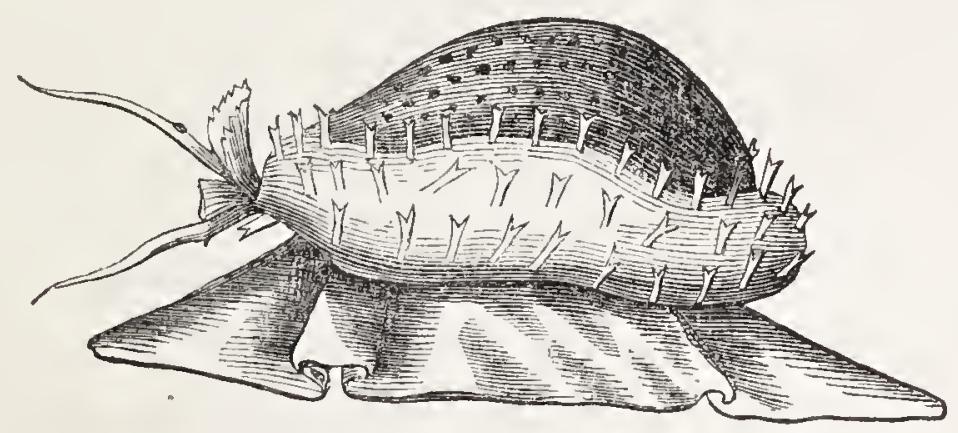

SEA-SNAIL.

The Sea-snails have their gills at very different spots: in the majority of them they are situated on the neck in a spiral cavity, and, like fish-gills, have a pectinated appearance. In others, they are on the right side, and covered by the mouth; 
others, again, have them on both sides of the body in a deep fold between the mouth and the body; while others, again, have gills perfectly free from the body on the back.

Nothing can be more graceful and various than the form and arrangement of the respiratory apparatus among the Nudibranchs. In the Glauci we find, on each side of the long body, projecting stalks which are covered with radiating threads; in the Briarix, there are a hundred forked arms which perform the process of respiration.

On the back of the Eolids, the gills are arranged in rows; in the Dorids, they surround the lower intestinal orifice in the shape of a regular garland. They cover the symmetrical wings of the Scylliæ like the hair of a pencil; while, in the Thetids, they appear in two long rows like two connected tufts. The external beauty of these animals responds to their beantiful mythological names; for whatever about them is not as transparent as the purest crystal, glistens with the brightest colours — red, yellow, and azure. Some Nudibranchs live on the coasts and crawl about the ocean bed with the aid of a tolerably developed ventral disc; others seek deep water, where they attach themselves to drifting sea-weed, or, with the foot turned upwards, float on their backs, in which operation the edges of their mantle, which they contract with a quick movement, and their fin-like branchix, serve them as a means of locomotion.

They are found in every sea, but especially in the warmer latitudes. Thus, the Mediterranean swarms with Thetids, Briariæ, and Glauci; and, according to Quoy and Gaymard, there are nowhere more Dorids than off the Mauritius.

Although entirely unarmed, the Nudibranchs are not left a helpless prey to their enemies. The transparency of the body, 
which renders many of them difficult to distinguish from the water, certainly protects them from much persecution; and the thick slime which their skin secretes, may guard them from numerous attacks. The Dorids, which are not so well formed for swimming, conceal themselves under stones; and the more leathery and flexible varieties of this class have even the ability of throwing off a portion of their mantle, as a sop to the enemy, while they escape at full speed.

The Norwegian naturalist Sars was the first to discover, that the Nudibranchs undergo a real metamorphosis; and, in the earliest period of life, are covered with a shell. The eggs, which, in some varieties, amount to several thousands, are always connected by a gelatinous spiral band, which attaches itself to corallines or submarine rocks. Before the young crawl out, they are seen revolving on their axes by the means of cilia; and, afterwards, swimming about in the same way in the water. The larva is extremely small, and resembles a Rotifer rather than a Mollusc. It is enclosed in a transparent, calcareous, nautilus-shaped shell, provided with a lid. The structure is very simple, and reveals no signs of those external organs by which the full-grown animal is distinguished. Sars was unable to follow the further development.

Nature never makes rapid leaps from one type of organization to another; hence, we see the naked Molluscs passing gradually through intermediate forms to the varieties provided with a perfect spiral shell. At first, a rudimentary internal or external shell is formed, which protects merely the most important organs; then its circumference increases step by step, till at last it covers the whole animal, as it were, with a carapace; and now the first traces of a spiral are found, which is 
more and more distinctly stamped, till we come to the nerfect snail-shell.

'The varieties of Gasteropods which form this succession, are much too numerous for us even to mention; still we will lay before our readers some of their principal types.

In the Aplysia or Sea-hare, a Gasteropod that resenıbles a large naked slug, the opened mantle forms two broad lobes on the back, which, when opened, display the finely-fringed gills in a cavity on the right side of the animal. A very thin, horny, and transparent shell which is concealed beneath the mantle, serves as a protection for these organs of respiration. The Aplysiæ are found in every sea. They inhabit the rocks on the coast, and crawl about on the sea-plants; some, indeed, employ the fringes of the mantle for swimming. Formerly evil propensities were ascribed to this animal; and it was believed, that the sharp, ill-scented, sticky slime, or dark purplecoloured fluid which they emit in large quantities on being touched, had the faculty of ulcerating the hand.

The Carinarix are wondrously formed; for they carry on the back a shell attached to a foot-stalk, beneath which the fringed gills emerge. At the lower part of the body, the foot forms a round disk, on which a sucker may be noticed. We may say, that the whole animal is dismembered.

The Carinarix live far from the coast, and swim about almost constantly, or attach themselves, by means of the foot, to floating objects. 'The handsomest and rarest specimen (Car'inaria vitrea) is found in the Indian Ocean; and rich collectors readily pay from forty to fifty pounds for a single specimen.

Passing over several connecting links in the chain, we come to the limpets (Patellce), which are entirely covered by a cup- 
shaped shell. They live on rocks in the sea, and attach themselves so tightly by the foot, that they can only be removed by introducing a knife between the shell and the stone. It has been calculated, that the larger varieties produce a resistance of $150 \mathrm{lbs}$., which, beneath the acute angle of the shell, is more than sufficient to defy the strength of a man. They often collect in large numbers at one spot; and an old author compares them to heads of nails driven into the rocks. The genus is divided into several species, which are met with in every sea. They live on the glutinous sea-weed found at low water covering the rocks. At flood-tide, they crawl slowly about, and graze on their marine meadows.

In the auricular shell of the Haliotids is found the first race of a spiral whorl. The disk has a number of holes perforated through it in a line running paralle: to the left edge, which grow larger the further they are from the point, and appear to aid respiration. The Haliotids are very beautiful

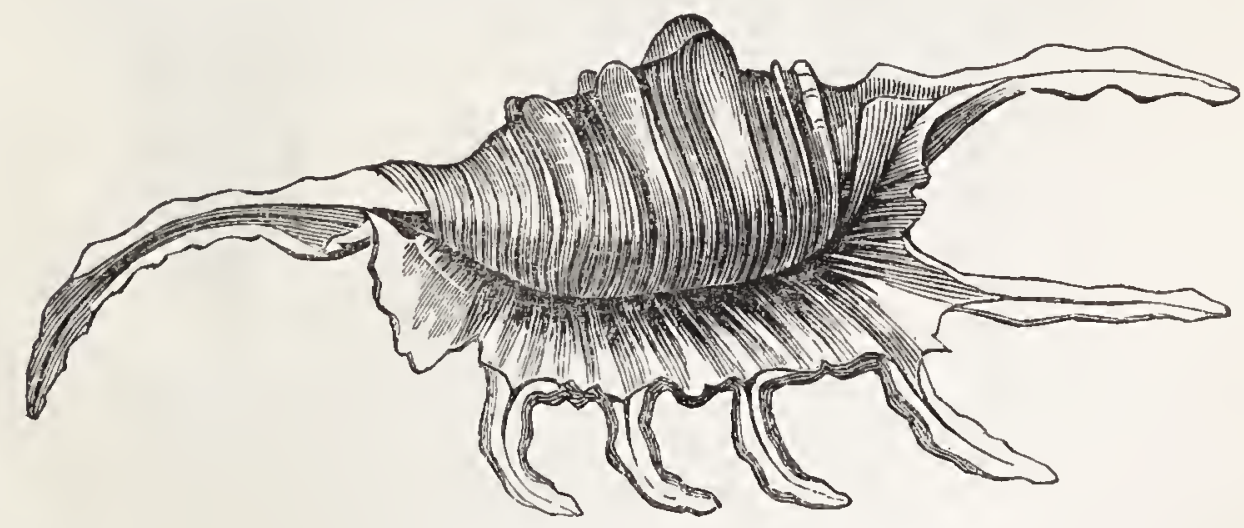

KNOTTY PTEROCERA.

shells; internally lined with mother-o'-pearl, and externallv red, green, and yellow, after the cuticle has been removed. They are very common in those spots they prefer, and serve as food for the poorer classes. Their pearl is employed for inlaying by cabinet-makers. 
If, in the Patellæ and Haliotids, the Sea-slug has a latitudinal extension, in the Dentalia it occupies a long, convex cone, resembling in form an elephant's tooth. These animals are found on the sandy coasts of nearly every sea, but especially in the tropics. But little is known of their habits.

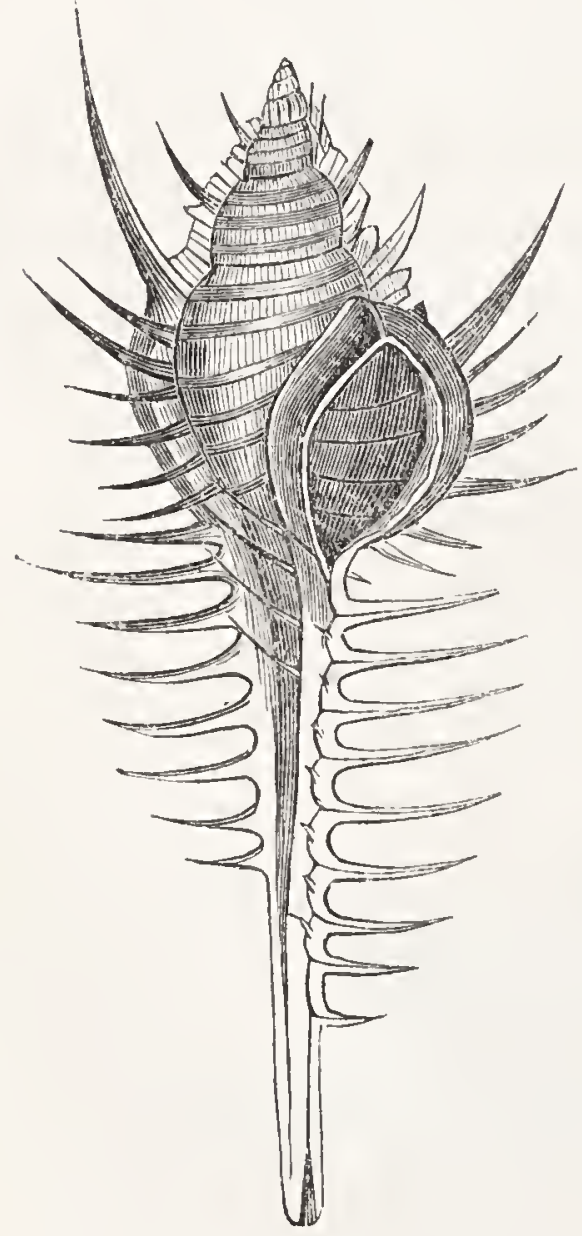

MUREX.

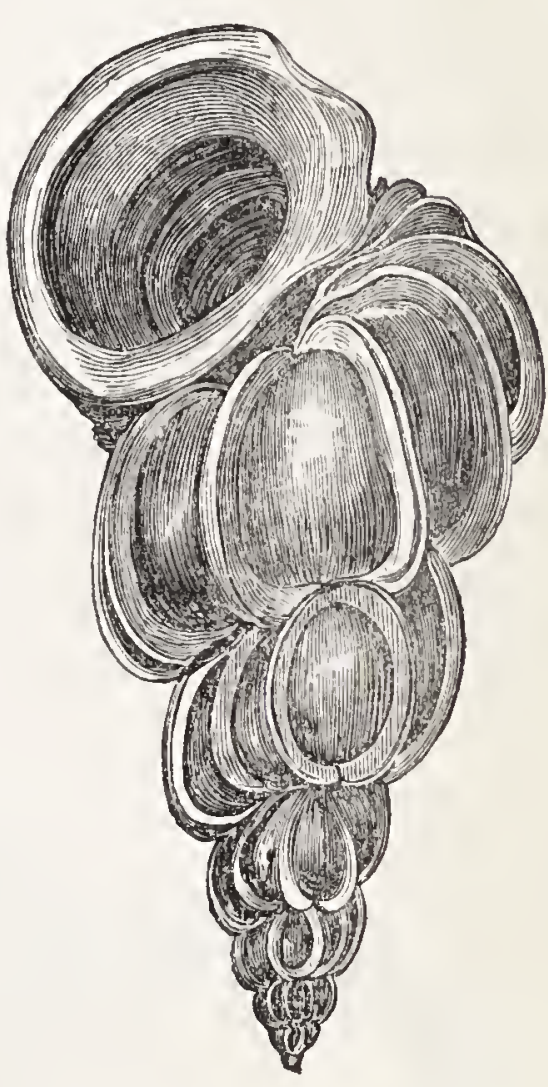

SCALARIA PRETIOSA.

The Spiral Conchiliæ all consist, in reality, of a tube gradually enlarged from the point to the mouth; but there is an unending variation of form and beauty among them. The same fundamental idea is presented to us in a thousand differert shapes, each more graceful or wonderful than the other. 
The mania of the conchologists is, therefore, quite as explicable as that of the tulip amateurs; and when we hear, that rich collectors have given hundreds of pounds for single bulbs,
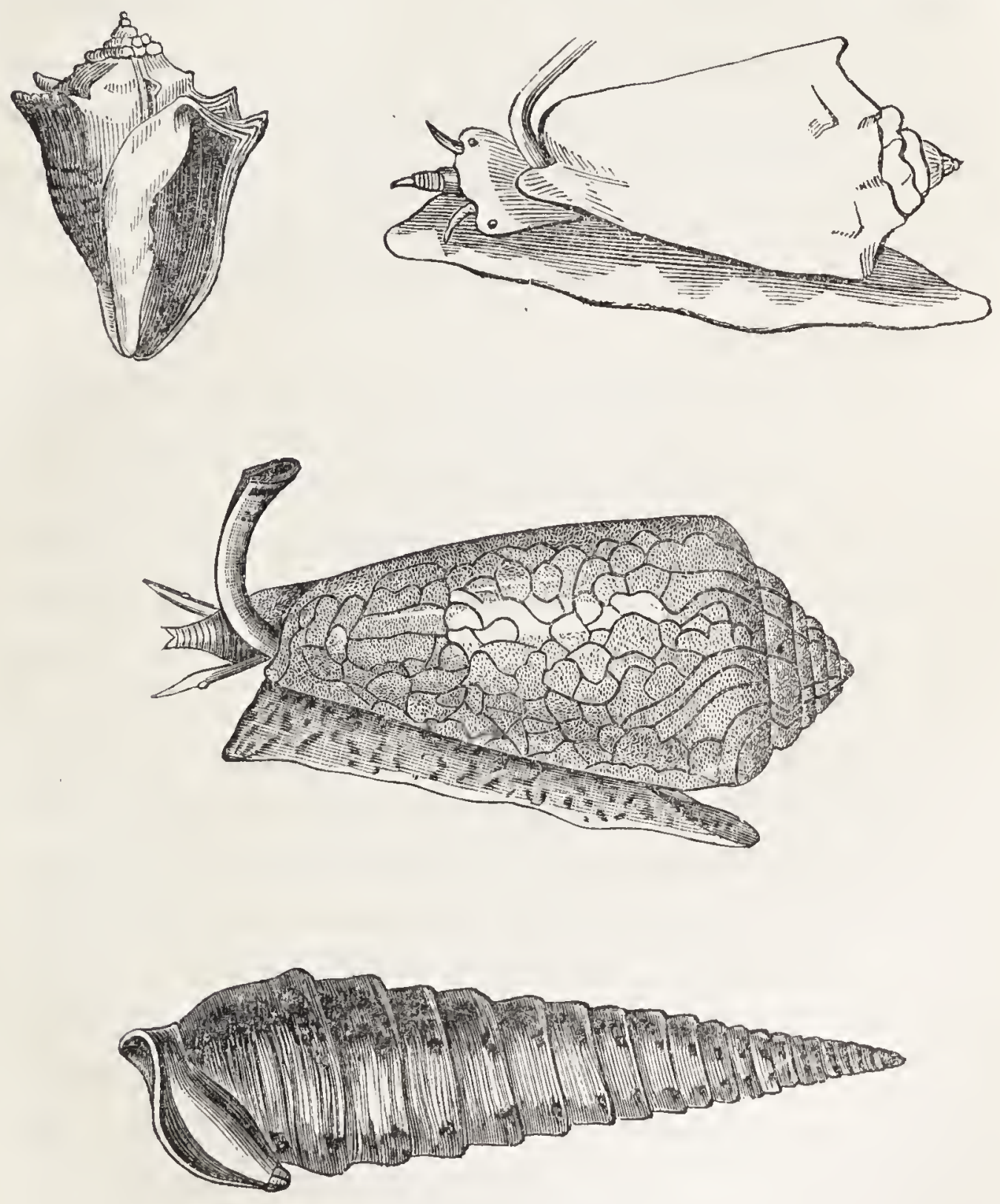

GROUP OF SHELLS.

we need not feel surprised, that formerly the Scalaria preciosa was worth a hundred louis d'or; and the Cypraca aurora, which the New Zealand chiefs wear round the neck as a symbol of 
their dignity, is still valued at forty pounds. The Giant Nerite is so rare, that rich amateurs will give any price for it. Some Volutes (especially Volute queue de pâan, and couronnée), Harps (Harpa nobilis), and Cornets, also command high prices. But then, the rule is equally true, that rarity is often overvalued; and even in this pursuit, fashion displays its vagaries. Any one who visits a large sea-port, will be able to buy, for a small sum, many of the most beautiful and graceful shells, which have only one fault: that nature offers them to man in too large quantities.

Though the house of the Sea-slug is sovariously constructed, its greatest value is in being a protecting apparatus, into which the slugs can withidraw their soft bodies on the approach of danger. In this respect, it is not uninteresting to find that those sorts which live on our coasts, and hence are most exposed to the action of the waves, possess a stouter and firmer house than those which live in deeper water: while the soft water molluscs, again, have much more tender shells than the ocean forms. The greater the need of protection, the more has Providence cared for sufficient defence. Most perfectly provided against external attacks are the larger Seaslugs, which not only reside in a powerful shell as hard as stone, but have also at the end of the foot a firm lid, which fits the orifice of their house exactly like a door, and, if necessary, cuts them off entirely from the outer world. This retirement into their fortress does not protect them, however, from all foes; for, as the French Admiral, Cécile, noticed at the Cape, the sea-birds often bear these shells to a great height in the air, and drop them on the rocks, which crack their shells.

The most usual mode of locomotion in the Sea-slugs is crawl- 
ing on the foot: in some varieties, especially those which are forced to lug a very heavy house about with them, such as the Cassis, Pterocera, etc., this is effected very slowly; while

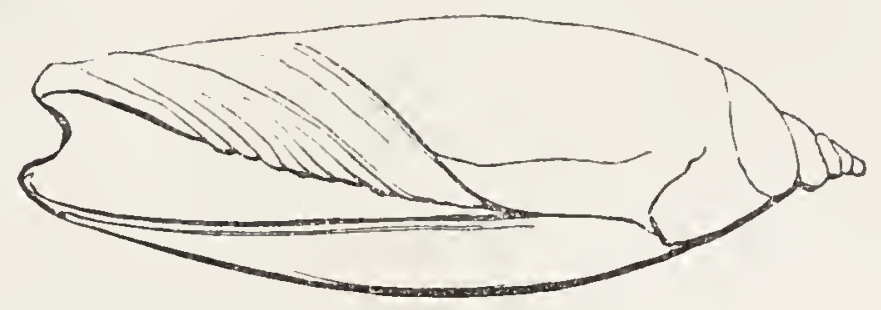

THE OLIVE.

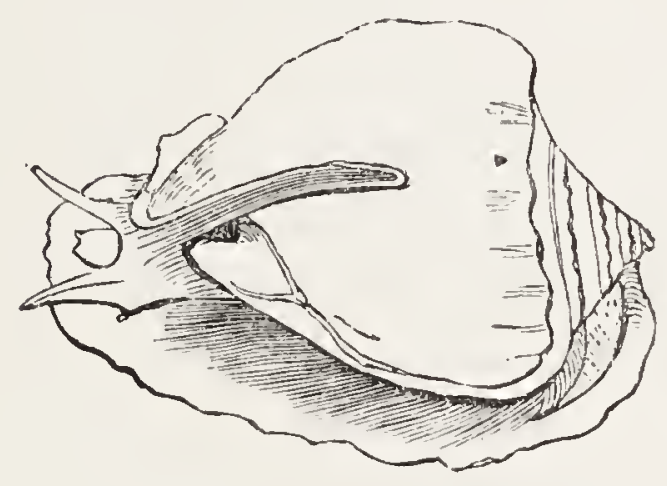

CASSIS.

others, like the Olives, which possess a proportionately very powerful foot, move about rapidly; right themselves very easily when overturned, and can even swim considerable distances, by moving the broad edges of these organs of locomotion back and forwards. But the speed of the motion is not always in proportion to the size of the foot, for the Patellæ, among others, possess a very large organ of locomotion, and yet crawl very slowly. They appear to employ it principally for suction. In some Sea-slugs, which, like oysters, do not quit the rock on which they first settled as larvæ, the foot has naturally no other purpose than that of an attaching organ; in some, such as the Vermetus and Siliquaria, it only serves to open and close the lid. 
Most of the shelled marine animals are, through their weight, confined to rocky or sandy stations. From this rule, however, the Ianthines form an exception, which have a very tender and most fragile shell, and whose foot is also provided with numerous bladders, so that it can float on the surface of the water. They inhabit the Mediterranean and the warmer parts of the Atlantic. The shores of St. Helena, and Ascension Islands are, at certain periods, entirely covered with them. In a quiet sea, they are often found on large banks, the foot turned upwards; at the slightest alarm, they empty the bladder and sink in the deep water, emitting the while a dark red juice, which, according to Lesson, produced the celebrated purpura, with which the cloaks of the Roman patricians were dyed, but which at present is not used in any way. The transparent shell of these little creatures is also of a beautiful violet colour.

The Sea-slugs live in various depths of water: some Coastsnails (Littorina rudis, Lamarckii) are only washed by the spring-tides, and hence nearly always remain out of reach of the water; others, among which are the Periwinkle (Littorina littorea)* and the common Whelk (Buccinum undatum), live rather deeper, so that they are at least bathed by every tide; others finally, such as the various Tops (trochice), always remain at the skirt of the lowest ebb-tide.

A far larger number of Sea-slugs live, however, quite out of the range of tidal oscillations, in a varying depth down to 500 feet.

The Sea-slugs are either predacious or herbivorous: the

* Turbo littoreus of the older naturalists. 
former seek mussels, whose shells they pierce with their rasplike tongue, or live on dead animals which chance brings to them. They seem to have a very fine scent, for animal substances let down in a net to the bed of the sea, will collect thousands of them in a single night.

The Sea-slugs, in their turn, fall a prey to other animals; but they have no worse foes than the Asteroids, which not only swallow the small young Gasteropods, but, by means of their arms, manage to seize and kill the larger sorts.

Although not so valuable to man as the Mussels, the Seaslugs are not without their uses. On every coast some esculent varieties are found (as the Littorina littorea, sold for food in Brittany and at La Rochelle), and we may say that, with the exception of a few species, which have a bitter taste, savage nations devour them all. The beauty of some of the shells recommend them as ornaments for our houses, while the Magelhaen volute serves the Patagonian as a cup; and the great Horn-mussel, the Arab of the Red Sea, as a water-jug.

The Pteropods move by means of two flapped fins, which grow like wings from the anterior part of the body; they have neither a foot for locomotion, nor arms for seizing their prey, like the Cephalopods and Gasteropods; but they approximate to them again by the possession of a head divided from the rest of the body. In the Hyalians, Cleodoræ, and Erisix, the posterior part is enclosed in a very thin transparent or pellucid shell, into which the animal, on the approach of danger, withdraws head and wings and sinks to the bottom; but the handsome blue and violet, red-dotted Clios are nude. The Pteropods are all denizens of deep water, and are only found 
near land when carried there by storms or currents. They swim freely about in the water, and, on calm evenings, come

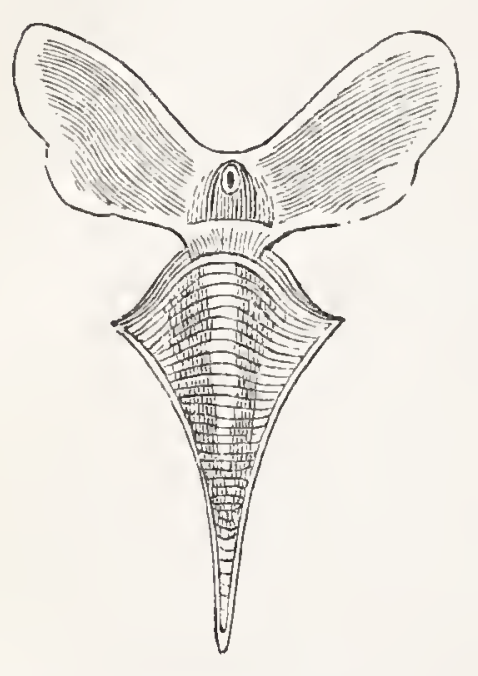

CLIO BOREALIS.

to the surface. Their movements are very active, and at times they are found attached to sea-weed, round which they throw their wings. They are little creatures; but they propagate so enormously that they (especially Clio borealis) supply the staple food of the colossal whale.

The Bivalves are distinguished from the above class of molluscs, not merely by a more simple construction, but also by the peculiar arrangement of their shells While the Sea-slug moves about on a powerful foot, the organ of locomotion appears much less fully developed in the most perfect Acephala; and, while the former projects from its shell a well-shaped head provided with feelers and glistening eyes, nature has denied the latter even a head. Still, the Acephala have not been treated by her in such a step-motherly fashion as might be supposed from their headless condition. Many among them have eyes, or at least ocular specks, which can distinguish light from dark; and organs of hearing have been very generally discovered among them.

The peculiar calcareous double shell in which they live, is a secretion from their bodies, in which they lie like a book in its binding, and which protects them against the attacks of their enemies.

The Sea-slug, on the approach of danger, withdraws into its simple house, whose opening it closes with a lid; the 
Mussel, on the other hand, closes its shell, and thus tries to avoid any unpleasant contact with the external world. A strong elastic ligament connects the two shells, and opens them widely so soon as the muscular contraction which closed them ceases.

In many of the bivalves, the skin flaps of the mantle are separated from each other, as, for instance, in the Oyster; in others, they dissolve more or less into the contractions of the

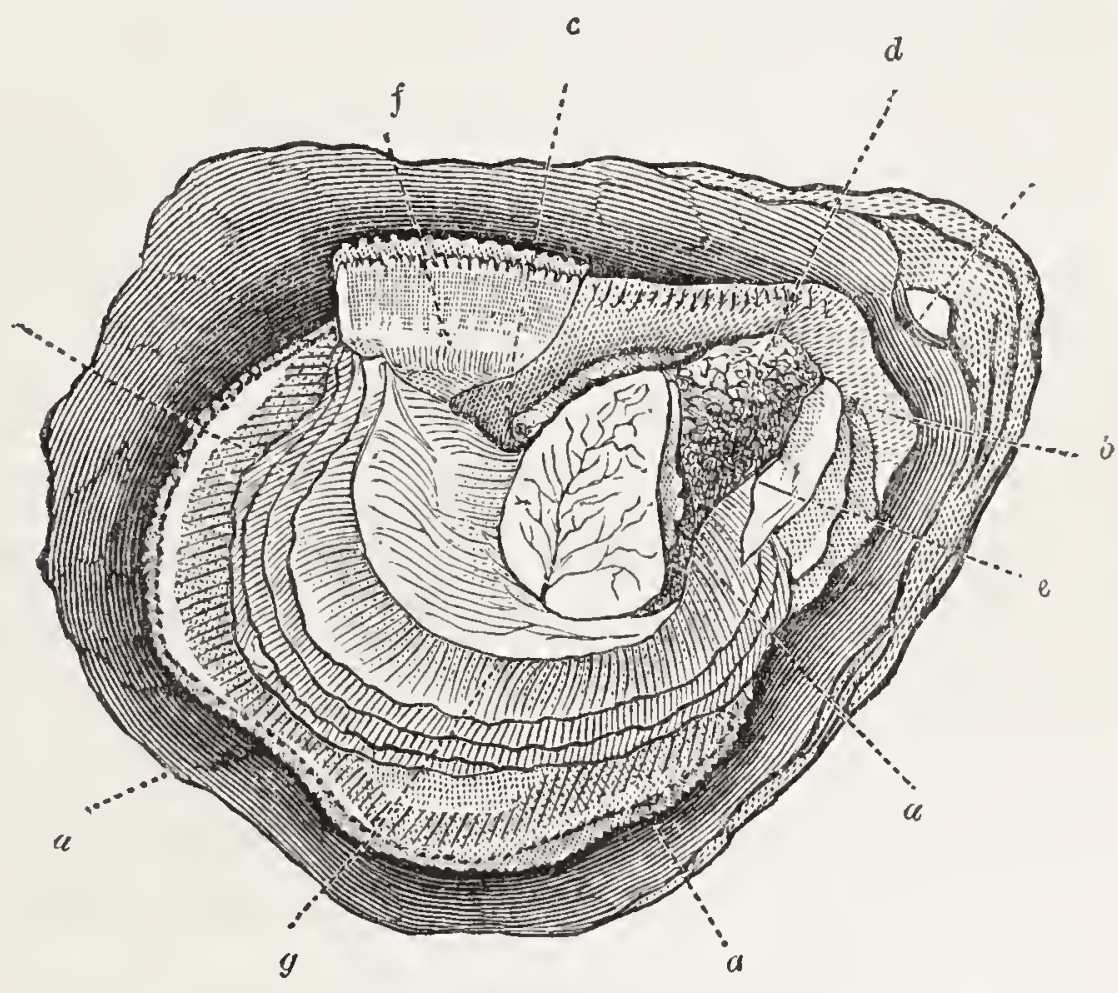

$a$ The for gill-lamellæ. $\quad b$ The mouth. $\quad c$ The vent. $d$ The liver. $e$ 'The heart. $f$ Portion of the mantle. $g$ Muscles of the shell.

stomach, and thus form a sac-like integument, which, however, is not attached immediately to the body of the animal, but is separated from it by a special cavernous space.

It must also be remarked, that this is confined to the tegumental portions; and the hard shells, as in the oyster, remain parted. 
In the closed sac are several fissured openings: an anterior one, which allows a passage for the foot; and two posterior, of which the hindermost serves for the emission of the secretions, while the other allows the water to flow into the cavity surrounded by the mantle. Frequently these two last openings are elongated into longer or shorter tubes, sometimes separated, sometimes growing together.

The beauty of this peculiar structure is clearly seen, when we regard the habits of animals equipped in this fashion. Nearly all of them bury themselves to a greater or less depth in the sand, and pass their life there, or at least a great portion of it. If their mantle were always open, as in the oysters, they would necessarily be suffocated - a danger from which they are protected by their long respiratory tubes.

The powerful muscular foot, which they extend anteriorly, usually serves them as a famous spade, by whose aid they rapidly hide themselves in the sand, if a foe try to surprise them ; many varieties also employ it for creeping or hopping, The common Cockle (Cardium edule), for instance, extends it as far as possible, presses it firmly against the ground, then rises by suddenly compressing it, and, rapidly repeating this manœuvre, moves along at a tolerable pace.

In other varieties, the motion is much more limited. Thus, the Razor Shells (Solenacece) are contented to rise and sink in the perpendicular deep holes they bore, and do not quit them. Most of the Bivalves, provided with respiratory tubes, live on the sandy and slimy coast, where they are found in such numbers that the flat sand is often covered with thousands of their empty shells; but there are some which burrow in wood or stone. 


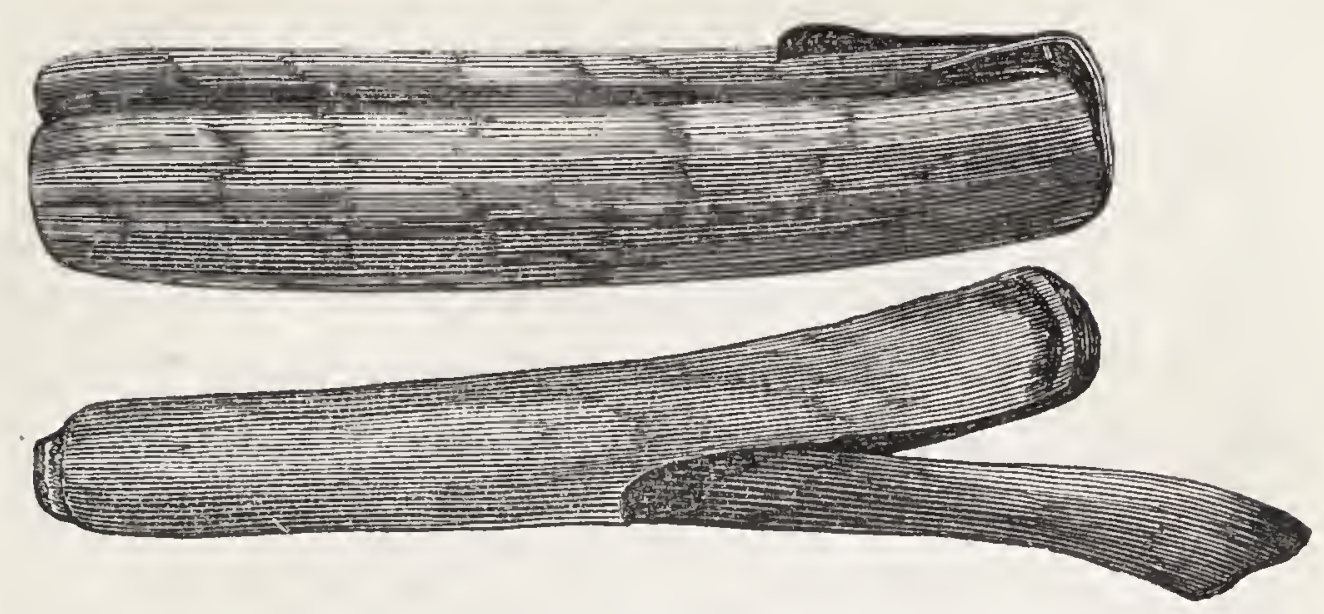

RAZOR SHELLS.

The Pholades secrete an acid juice, which softens the rock, so that they can then easily excavate it by the aid of their shells. In this way, with the gradual growth of the animal, a pear-shaped cavity is formed, in which it is compelled to pass its whole life. The thicker portion of the body, on which the very short and powerful foot is found, fills the broad bottom of the excavation, while the long respiratory tube, which supplies the imbedded Pholas with its supply of water, is pointed towards its narrow orifice. 'The movements of this animal are restricted to rising and sinking in its narrow prison. The majority are small, but there are some varieties which attain a length of five inches.

The fragile shell of the Pholas seems to have compelled it to burrow in hard stone; a similar necessity may compel the Teredo to dig its abode in wood.

The shell of this animal is very small in comparison with its worm-like body, which frequently grows to the length of a foot; and hence it cannot be regarded in the light of a protection. In order to live in security then, the Teredo bores into submerged wood deep passages, a quarter to a half 
inch in diameter, whose walls it plasters with a calcareous mass, closing the opening with two small lids.

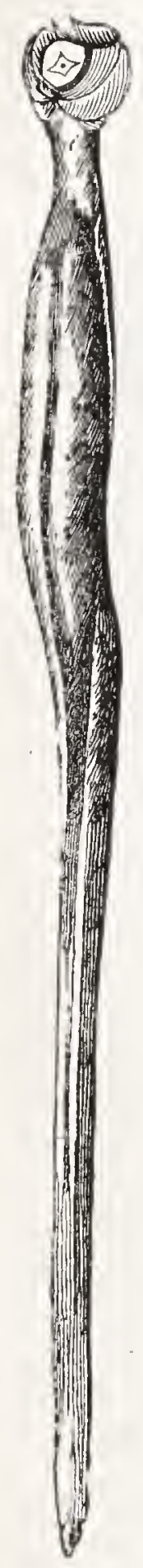

TEREDO.

As it is very prolific, it has produccd great injury in vessels and submarine buildings. As a protection against it, ships are covered with copper, and beams under water are thickly studded with nails. In the last century, it bored through the Dutch dykes to such an extent, that serious apprehensions were entertained for the safety of the country; and it cost millions to repair the damaged bulwarks.

Thus, a tiny animal caused the Batavians to tremble, whose heroism had braved the might of Philip II. and Louis XIV.

Still, it would be most one-sided and unjust, were we not to recognize the service the Teredo offers man. If it has been a destroyer of useful constructions, on the other hand, it removes wrecks and sunken vessels, which might prove very dangerous to coasters, and silt up the entrance to many ports and rivers. It is very doubtful whether these benefits do not largely outweigh the mischief they cause.

The Pholades are also among the injurious animals; they gnaw and bore walls and calcareous piers, which man erects against the assaults of ocean, or for the purpose of forming artificial harbours and landing places, or they undermine their foundations, and gradually produce their destruction. 
In addition to the great number of Bivalves, which burrow in the sand or mud, in stone or in wood, there are many others, which live on the bed of the sea, where they usually lead a gregarious life, collected in large banks. As, on opening their shells, they have no reason to apprehend suffocation by earthy matters, like the former, their mantle-folds are more or less divided from each other, so that the circumambient water has immediate access to their finely laminated gills.

The majority of them are fastened to foreign bodies, either by the shell or by the aid of the byssus or beard, a fibrous mass which is spun out from the foot. The Pecten, which lives on rocks, can contrive to move very quickly without feet, by opening and closing its shells rapidly, and the File or Rasp-shell (Lime), a variety specially found in the Indian ocean, flies in this way so rapidly through the water, that Quoy and Gaymard, though light-footed Frenchmen, were obliged to run in order to catch it.

The structure giving very limited locomotive power to the Bivalves, necessarily prevents them falling on their prey, and they are therefore satisfied with what the sea washes up to them. Fortunately, salt water is so enormously rich in microscopic creatures, that their modest appetite is fully satisfied in this way. The currents, which reach the lungs either through the open shells or the respiratory tubes, also carry the necessary aliment matter to their mouths.

On the other hand, the Bivalves are exposed to a grand army of enemies. Strand-birds, Asteroids, Fish, Crabs, Sea Slugs, and Annelids swallow them by myriads; and man eats nearly every variety. In vain does the Seafinger (Pholas dactylus) burrow in the hard rock, or the Cockle hide itself 
in the sand; their primæval security was gone, so soon as man once discovered their flavour. The former was considered by the ancients a great dainty; and the latter is even frequently preferred to the Oyster. So much is certain, that during late years it has saved many inhabitants of the Shetland and Orkney islands from starvation.

Among the best Shell Fish may be counted the Razors, which are famous eating when roasted; the Venus cancellata or Clovis, a favourite esculent of the Provençals; and the Gapers, which are devoured not only by the Greenlanders, but also by the Walrus and the Arctic fox.

The gregarious common Mussel (Mytilus edulis), which is met with on nearly all stony coasts, in the littoral zone extending between ebb and flood, is eaten by myriads. It supplies a very cheap and pleasant article of food; but it is not very digestible, and at times is poisonous, which, according to Durandeau, may be ascribed to the Asteroid eggs, on which the Mussel feeds in the summer months.

In the north, the common Mussel is also used as bait for Cod, Haddocks, Halibuts, Rays, and other large fish, which are caught with a line. In the Frith of Forth alone, thirty to forty millions are employed annually for this purpose, and in many places they are kept in mussel gardens or enclosed patches of the beach, whose bottoms are covered with stones, to which they attach themselves by their beards.

The artificial breeding of mussels was introduced into France so early as 1235 , by Walton, an Irishman. Having been wrecked on the Bay of Aisguillon, and forced to support life on marine birds, he soon noticed that the mussels, which attached themselves to the posts, by the aid of which he 
spread his nets over the swamps, surpassed in size and flavour those growing naturally in the slime, and improving his discovery, he established the first Bouchot, or Mussel-garden, formed of posts and plaited oziers. His example found imitators ; and, curiously enough, the method employed by Walton six centuries back is still in vogue. We can form an idea of the enormous value which might be derived from the numerous utterly neglected lagunes on many parts of the coast, when we learn that, although the fishermen of l'Aisguillon sell three hundred pounds weight of Mussels for the low price of five francs, they annually carry to market enough of these molluses to produce from $£ 40,000$ to $£ 50,000$.

The praise given to the Oyster by, Pliny the elder, who called it "Mensarum palmam et gloriam," is still enthusiastically repeated by countless admirers. It is Queen of all the Molluscs. It is well known, leads a gregarious life, and forms large banks, principally on rocky soil ; though it is also found on sand, or even in slime. In the tropics, it frequently attaches itself to the roots and branches of the Mangrove trees that grow at the edge of the water, and at ebb tide they are seen oscillating in the air. The Oyster is an inhabitant of all European seas up to the high north, where it finds its limit at Bestenfiord ( $68^{0}$ N.L.), but the British waters must be regarded as their principal habitat, as they are found no where else so numerous and so good. Even the Normans preferred the Oysters of Cantium to those of the Lucrine Lake, Brindisi or Abydos. The coasts of Brittany and Normandy are also renowned for their celebrated Oysters.

In spite of their high price, which limits their enjoyment almost to the tables of the rich, enormous quantities of Oysters 
are devoured. During the season of 1848-1849, 130,000 bushels were sold in London; and, in 1853, Paris consumed a quantity representing the value of $1,641,359$ francs. In 1828, the French banks in the channel supplied fifty-two millions, and we read in Mylne Edwards, that in 1817, the little seaport of Grandville kept seventy-two boats incessantly employed in the Oyster fishery from October to April.

In trade there are three varieties of Oysters:

1. Those which are dragged from the deeper beds by an iron dredger, and caught in nets. These are the largest, but least estimated.

2. Those, collected on the banks, which rise higher from the water, and are nearer the coast. As these animals are exposed to the daily change of ebb and flood, and frequently remain dry, they have the habit of retaining the water in their shells for a lengthened period, and hence can be sent for greater distances than the former, which soon expel their water and pine away. Those are preferred, which are collected on a clean soil, and at the mouth of rivers.

3. Those Oysters which are kept in artificial tanks or parks. This trade was known to the Romans; and Pliny mentions the Knight Sergius Orata, who lived in the time of the orator, Lucius Crassus, as the first who laid such an Oyster nursery in the Lucrine Lake, and gained enormous wealth from it.

The modern Oyster breeding is specially carried on at Harwich, Colchester, and many other English coastal towns; at Marennes, Havre, Dieppe, Treport, etc.; and Ostend has gained a well-merited reputation not only through its sea-baths, but also through the excellence of its Bivalves, which in winter are sent even as far as Warsaw. In Ostend, the Oyster-beds, 
which are seven in number, consist of large basins lined with masonry, and connected with the sea by means of gates. As the salt water can remain for a longer period in these basins, a larger number of infusoria is developed in it, so that the Oysters find here more abundant food than in the free element, and grow very plump, At the same time, the greatest care is taken of their health, and they are laid separately lest they might disturb each other. In this manner they are nursed and improved by art, and far surpass the raw children of nature, which, not having enjoyed the advantages of a well regulated physical training, are carried straight from their submarine homes to market, and handed over to the murderous steel.

The well-known Green Oysters obtain their colour from the great quantity of ulvæ, enteromorphæ, and microscopic algæ found in some of the tanks, which give the water a greenish tinge, and are swallowed by the Oysters.

If we take into consideration the continually increasing demand for Oysters, the comparatively small number and size of the artificial beds where these molluscs are bred, and above all, the carelessness and waste with which the collection on the natural beds is performed (for, blindly confiding in the abundance of Ocean, people only care for increasing the present supply, but do not think of the wants of the future), there is reason for apprehending that the time is not far distant when both consumers and fishelmen will complain of the exhaustion of the beds. To guard against this danger it would be, certainly, highly desirable that the Oyster fisheries should not only be more carefully watched, but that arrangements should be made for the formation of new natural beds, 
and carrying on the artificial breeding on a larger scale. The possibility of such a thing is proved, not only by the history of Molluscs, but also by experiments already made.

The spawning time of Oysters is from June to September. Instead of leaving their eggs at once to their fate, like the majority of marine animals, they remain for some time in the folds of the mantle, between their gill plates, where they are surrounded by a slimy matter. After growing in this fashion, the microscopic larvæ, provided with a natatory apparatus and eyes, are carried by thousands from the mother's shell and are drifted about by the current, till they find a firm substance to which they can attach themselves. Thus, the Oyster annually produces during the summer no less than one to two million young, the greater part of which, however, perish during their wanderings.

We see then, what an abundant reward industry would receive, if it succeeded in protecting the young Oyster brood and rendering it stationary at an early period; and that this could be easily effected in many places, is proved by the artificial Oyster-breeding in the Lago di Fusaro.

Between the Lucrine Lake, the ruins of Cumæ, and the promontory of Misenum, there is a small salt-water lake, about four miles in circumference, from three to six feet deep, and resting on a volcanic, black, slimy bed. This is the Acheron of Virgil, the modern Fusaro.

Over the entire surface are seen, at regular distances, large heaps of stone, which are taken there and covered with oysters from Tarento. Round each of these artificial rocks, which are generally six to nine feet in diameter, a number of poles are driven into the ground rather close together, pro- 
jecting slightly above, so that they can be easily drawn out. Other poles stand in long rows seven feet apart, and are
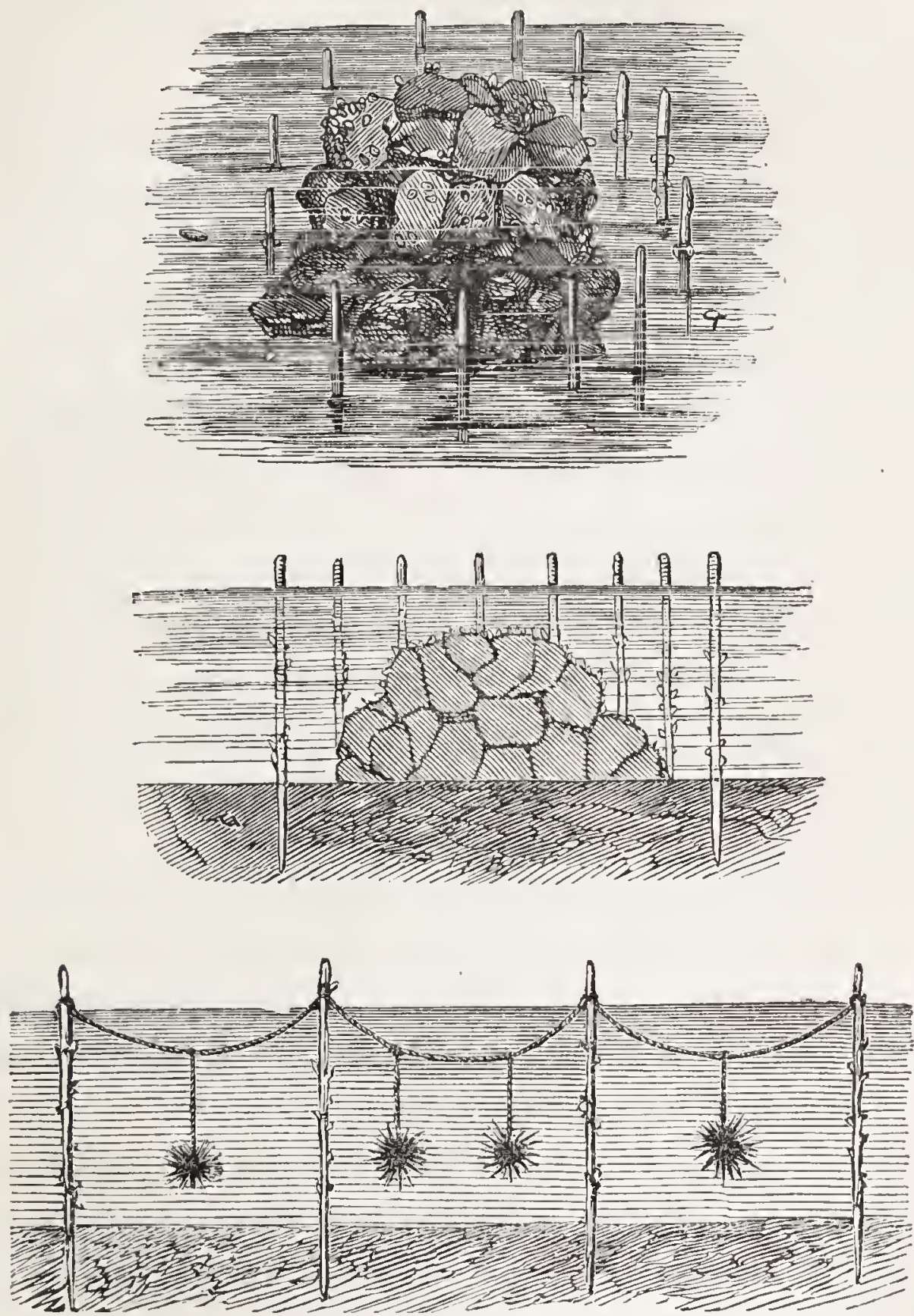

THE ITALIAN OYSTER BREEDING-FRAME.

fastened together by cords, from which bundles of twigs hang down into the water. 
All these arrangements are intended to serve for collecting the Oyster dust, which annually issues from the mother's mantle, and offer it a number of points of contact, to which it can attach itself.

In two to three years, the microscopic larvæ are converted into excellent Oysters. At the proper season of the year, the poles and bundles of twigs are drawn from the water, the ripe berries of this artificial grape removed, and the apparatus is again submerged, till a new generation produces a new crop. Thus, the Neapolitans, who are usually abused for their sloth, give all the coast-inhabitants of Europe an example, which deserves their closest attention ; for in every country there are localities where a similar course of treatment, modified by circumstances, would convert dead lagunes and bays into luxuriant Oyster beds. It would even be an easy task to suspend bundles of twigs over the natural beds, which would catch a good portion of the larvæ, which could then be transplanted.

About a hundred years ago, an English gentleman had a few oysters thrown into the Menai Straits, where they have grown so rapidly, that they even cover the entire bed of the sea, and have become a rich source of revenue to the descendants of this provident gentleman.

We will now pass to another valuable bivalve production : to the real Oriental Pearls, which have always been valued equally with diamonds. They are produced by the Pearl Oyster (Meleagrina margaritifera) which is found in many parts of the Indian and Pacific Oceans, but principally in the Gulf of Manaar, off the island of Ceylon, where their beds, the largest of which lies opposite Condatchy, extend for miles from the 
coast, on submarine rocks. Before the commencement of the fishing the Government have the beds inspected, and they are let to the highest bidder, or the business is carried on by Government at their own risk and peril. In order not to rob all the beds at once, only a portion of them is fished annually, and thus a certain and regular crop of pearls is insured. The fishing begins in February, and is ended by the beginning of April. The boats engaged in it collect in Condatchy Bay about twelve miles from Manaar. At gun-fire they all start together, at 10 at night out to sea, reach the beds about daybreak, and fish till mid-day. Then a second cannon gives the signal for returning to the Bay, where the owners are waiting for the boats, and carefully watch the unloading, which must be over by night. In each boat, there are twenty men and one master; ten rowing and pulling up the divers; other ten go down into the sea, four at a time, and thus, by alternately rowing and diving, . keep their strength till the end of a day's work. When a man dives, he seizes a cord with the toes of his right foot, to which a stone is fastened for more rapid sinking, while the other foot grasps a purse-shaped net.

In the right hand he takes another cord ; with the left, keeps his nostrils closed; and thus quickly reaches the bed. Here he fills his net most cleverly, as he can only devote two minutes to collecting the oysters.

As these divers are accustomed to the work from their earliest youth, they do not fear sinking fifty to sixty fathoms, and frequently repeating this laborious task. They will dive some fifty times in a morning, and each time collect about one hundred Oysters, At times, however, thiey are so affected by the task, that blood flows from the mouth, nose, and ears. 
Although they generally remain but two minutes under water, some are able to stand it for five minutes.

During the fishing a number of Magicians and Priests stand on the beach, busily engaged in protecting the divers from the ferocity of the sharks by their incantations. These brutes are greatly feared by the fishermen, and their confidence in the talisman and prayers of the priests is so great, that they neglect all other precautionary measures. The divers are either paid in money, or receive a share of the still closed Oysters proportionate to the number caught. They must be strictly watched, for they are often guilty of robbery; at times they will even swallow pearls they find at the bottom of the sea in open shells.

The Oysters, on being landed, are laid by the owners on mats in carefully closed rooms, till the animals die. Then the shells are easily opened, and both the loose and sessile pearls collected. Frequently, too, the Oysters are separated from their shells and boiled, because pearls are found in the interior of the body and under the folds of the mantle.

After the fishing is ended, the largest, thickest, and handsomest shells are selected, which supply the mother-o'pearl ; the rest are left lying on the beach, and these large piles of Molluses poison the whole neighbourhood for a considerable period. But for all that, Indians may be found, months after, turning over the corrupting mass, in the hope of finding a few forgotten pearls.

The Pearls are bored and threaded in the country, a task which is performed with admirable rapidity and skill. Powder of pounded pearls is used to cleanse, round, and polish them. 
The South Sea also supplies the fashionable world with these valuable ornaments; but the Pearls of California and and Tahiti are rarely introduced into trade, and have not the regularity and lustre of the East Indian.

Pearly excrescences are also found at times on the inner surface of the shells of our oysters and mussels. They are produced in the same way as the true Pearls, about whose origin, however, the naturalists are not quite agreed. We are stated to owe them, according to some, to a disease peculiar to the animal, which occasions such a strong secretion of the pearly substance, that it does not lie in strata on the bottom of the shell, but now and then forms excrescences, which harden into shapes more or less regular. Other naturalists are of opinion that the animal piles up this substance, to give the shell greater firmness and thickness, at any place where it has been perforated by marine worms, or injured in any other way. According to Philippi's investigations, the formation of Pearl is due to an intestinal worm, which is rendered innocuous by the exudation of the Pearl mass from the mantle. Lustre, size, and perfect regularity of form are the most material qualities of a fine Pearl. If it is rare to find all these conditions united in a single specimen, it is naturally far more difficult to collect into a valuable ornament a number of Pearls of the same size and beauty.

Most of the Pearls found are imperfect and irregular : such as Seed-Pearls; and there are some concretions attached so firmly to the shell that they cannot be separated from it. The form and size, therefore, give the Pearls their chief value, for the large and thick shells of the Pearl Oyster, which cost so 
much less, are entirely formed of the same substance, and display alternately a similar lustre.

Nature has given to the Bivalves the same beauty of colouring and variety of graceful and curious forms, as to the Univalves, so that they play an equally important part in all collections; and some fetch large sums.

Among the finest and most valuable varieties, are the Spondyli, which inhabit tropical waters, attach themselves to rocks like the Oysters, and are also eaten like them, though not nearly so delicate. They are distinguished by bright colours, but more especially by the long thorns and spurs

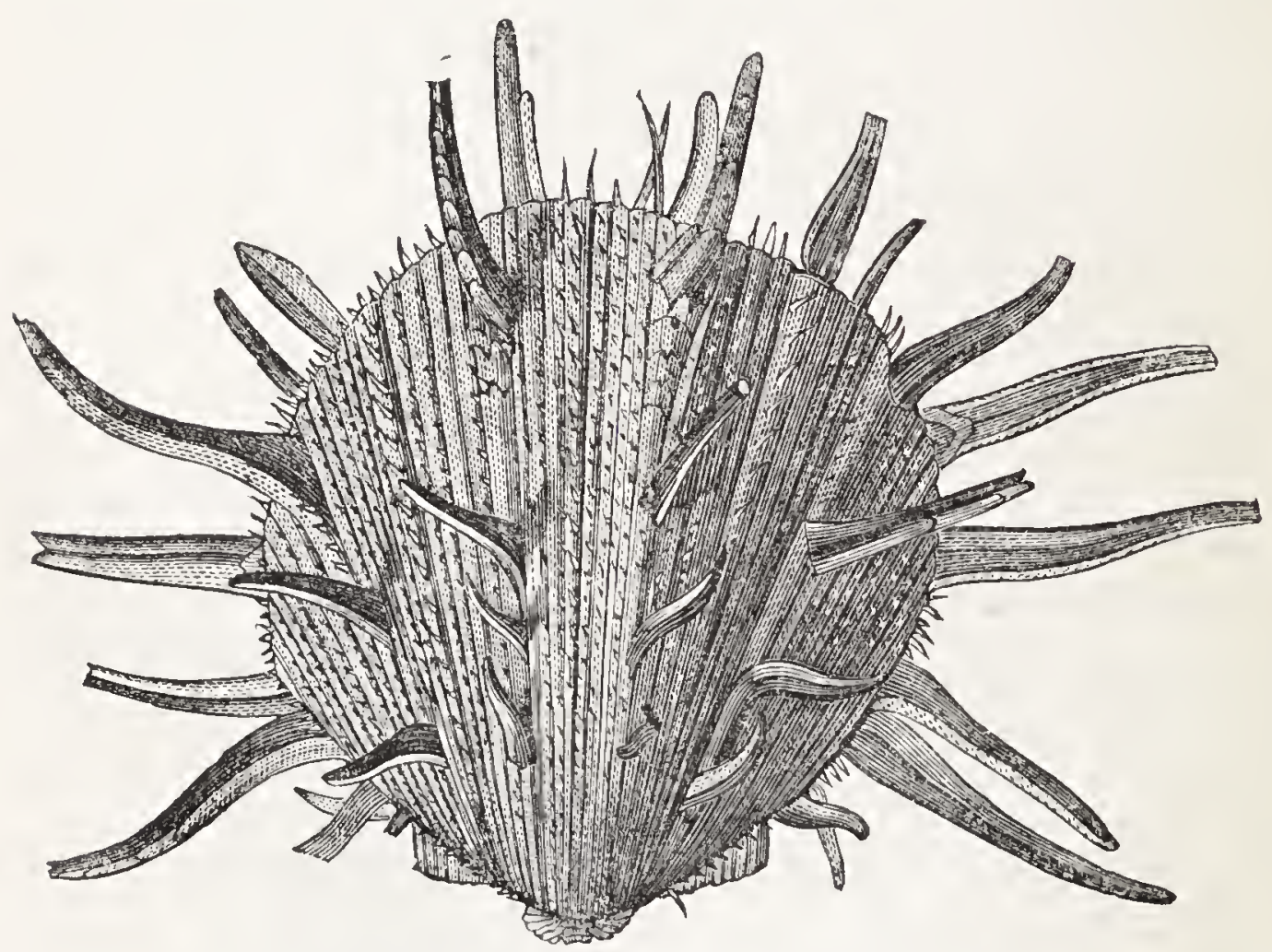

T HORN OYSTER.

with which they are covered, and for this reason they are also called Thorn Oysters (Huîtrés épineuses).

In no royal museum, are the Spondyli so richly represented 
as in the shell collection of M. B. Delessert at Paris, the most perfect in the world, which, among other varieties, contains the two handsomest known specimens of the Spondylis regius, a shell so rare, that there is only one other example in Europe. No Tulip ever carried an amateur further from reason, than the longing for such a wondrously beautiful Thorn Shell did M. R — Professor of Botany at Paris. The price of the Spondylus was 6,000 francs, a sum that far exceeded all the savings of the Savant. Unhappily, the hard-hearted seller would not listen to any suggestions about giving credit. The dilemma was painful ; but greater still the longing of the collector, who, at length determined to turn his humble stock of plate (naturally without his wife's knowledge) into money, and thus placed himself in possession of the glorious Spondylus, which, in the joy of his heart, he christened the Regal.

But the dinner hour arrives, and we can conceive the amazement of the lady of the house at the strange metamorphosis that had taken place in her plate basket. The happy professor hurries home delighted, but the nearer he approaches his Penates, the slower his walk becomes; his cheerful brow is over-clouded; the reception that awaits him begins to grow serious. But with such a treasure in his pocket, a man can defy a storn ; and so he determines, after some hesitation, to appear before his enraged wife. But he was not prepared for such a storm as now burst upon him, his courage failed him; he forgot the shell. In his despair, he threw himself in his chair, and was only reminded of the presence of his treasure, by the terrific cracking of the box that contained it. Fortunately, only two thorns were broken off, but 
the terror of the poor collector was so profound, that his wife had not the heart to upbraid, but began to console him.

In former times, the Giant Shell (Tridacna gigas), which is now met with in every shop, was considered one of the greatest rarities. In the church of St. Sulpice, there is one, by no means the largest size, which was presented to Francis the First by the Republic of Venice, and is now used as a font.

This shell fish is about four feet across, and weighs from four to five hundred weight, the meat alone weighs thirty

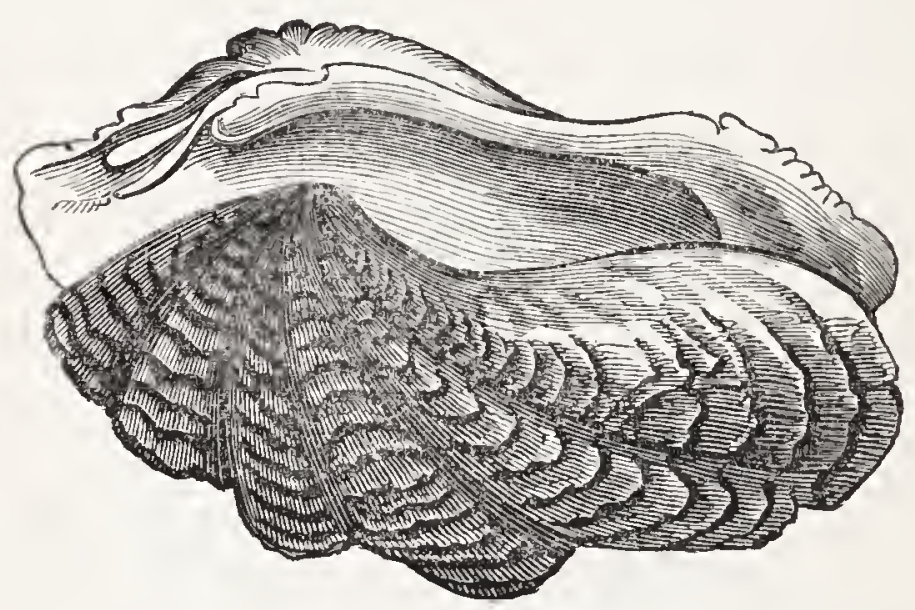

TRIDACNA GIGAS.

pounds. The muscular strength of the animal is said to be so great, that by closing its shell it can cut through a thick rope or chop off a man's hand. This Tridacna is found in the Indian and Southern Ocean, in Carteret Harbour, in New Ireland, at Tonga-Taboo, at the Moluccas, Timor, and off Waigiou, to the north of New Guinea. At first it attaches itself by means of a byssus, but afterwards lies freely on the coast or coral.

The Tridacna, and its near relative, the Hippopus, are distinguished by their magnificent colours. The mantle of the 
Tridacna safranea, described by Quoy and Gaymard, is at the edge dark blue and azure, with emerald spots, and inside a bright violet. When a large number of these animals unfold their glorious hues in shallow water, no garden or flower-bed can equal them in beauty.

The Brachiopods, to which the Terebratæ or perforated mussels belong, live, like the above described Acephala, in a double shell, but have no feathery gills; and in every respect are at a lower stage of organization. They attach themselves to submarine objects by means of a fleshy band. The mouth is

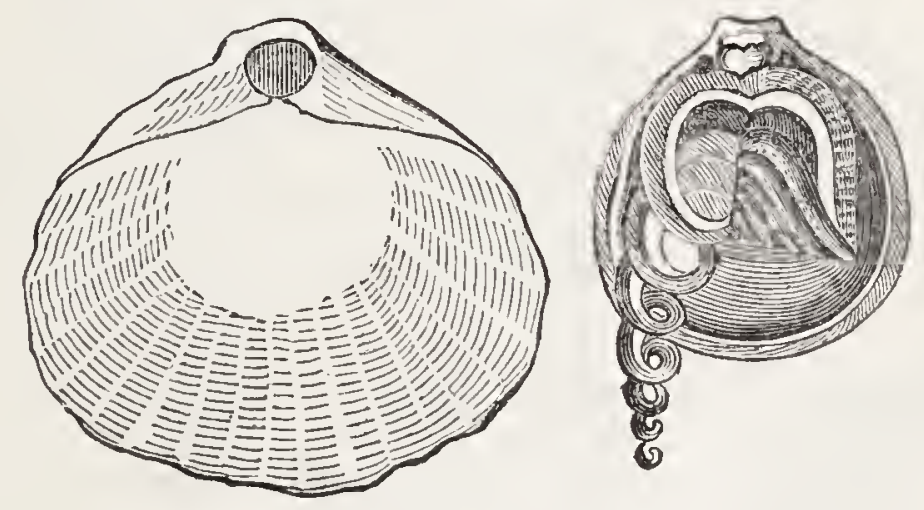

TEREBRATA.

situated between two fringed spinal arms on the stomach, which serve to open the shell and seize the food. There are only a few existing varieties; but a large quantity of fossils, so that they are of great importance to the geologist, though otherwise but offering but little interest.

The Bryozoa and Tunicata are also reckoned among the Molluses. Among the former, we notice the Flustræ, which were formerly considered Polypi, because, like them, many thousands of them inhabit a common leaf-like hive of the thickness of paper; but, in their internal structure, they differ 
greatly from these simple animals. * To the Bryozoa also belong the Lepralix, which are so frequently found like a delicate net work spread over the leaves of Algx. To the
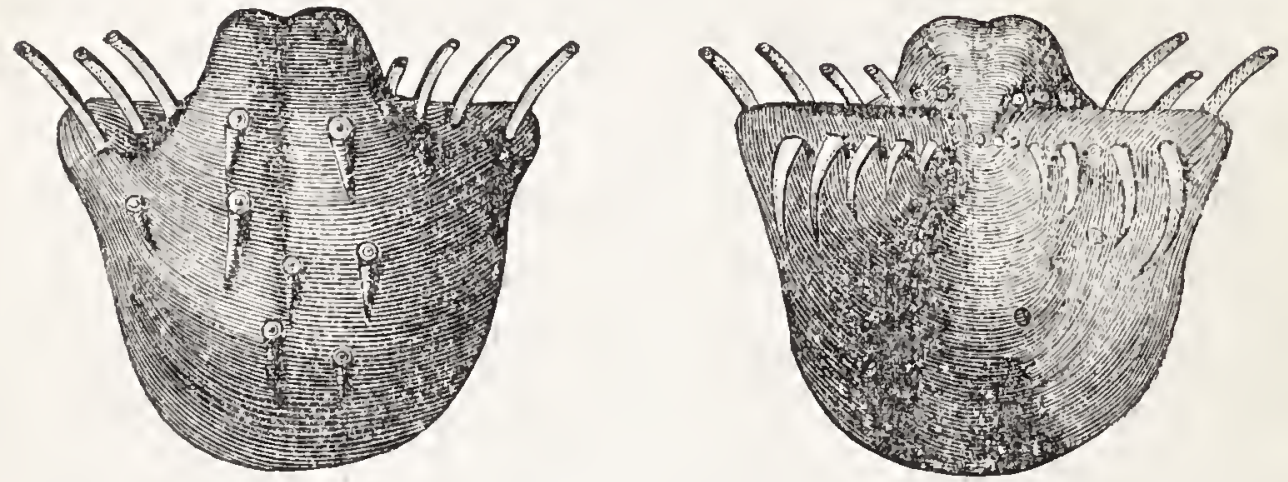

FOSSIL SHELLS.

unaided eye, they appear like a thin calcareous crust; but, if inspected through a magnifying glass, an astounding variety and gracefulness of form may be noticed in these animals, of which near forty varieties are found in the German Ocean.

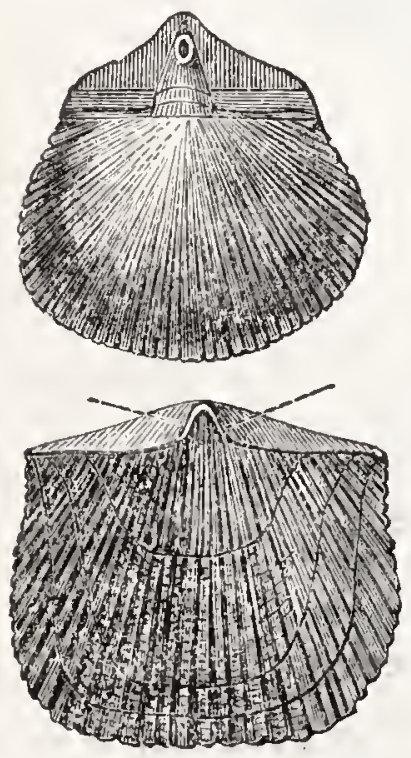

The Tunicata comprise no less wonderful creatures in the Ascidians, Pyrosoma, and Salpæ. The Borylli, which belong to the former class, form a gelatinous crust, covered with little stars, on the sea-weed. Each branch is the body of one of the individuals of which the strange colony is composed; and in the centre is the intestinal opening common to all. We shall speak of the Pyrosoma in the chapter devoted to the rossil bracinorods. phosphorescence of the sea. The Salp

* The Flustre are so common on our own shores, that it is rare to examine the refuse line of high-water without meeting with them. 
lastly demand our attention through their most extraordinary alternation of generation.

They inhabit the warmer seas, and swim freely, generally in considerable bodies. Each animal resembles a crystalline tube, through whose parietes the internal coloured parts can

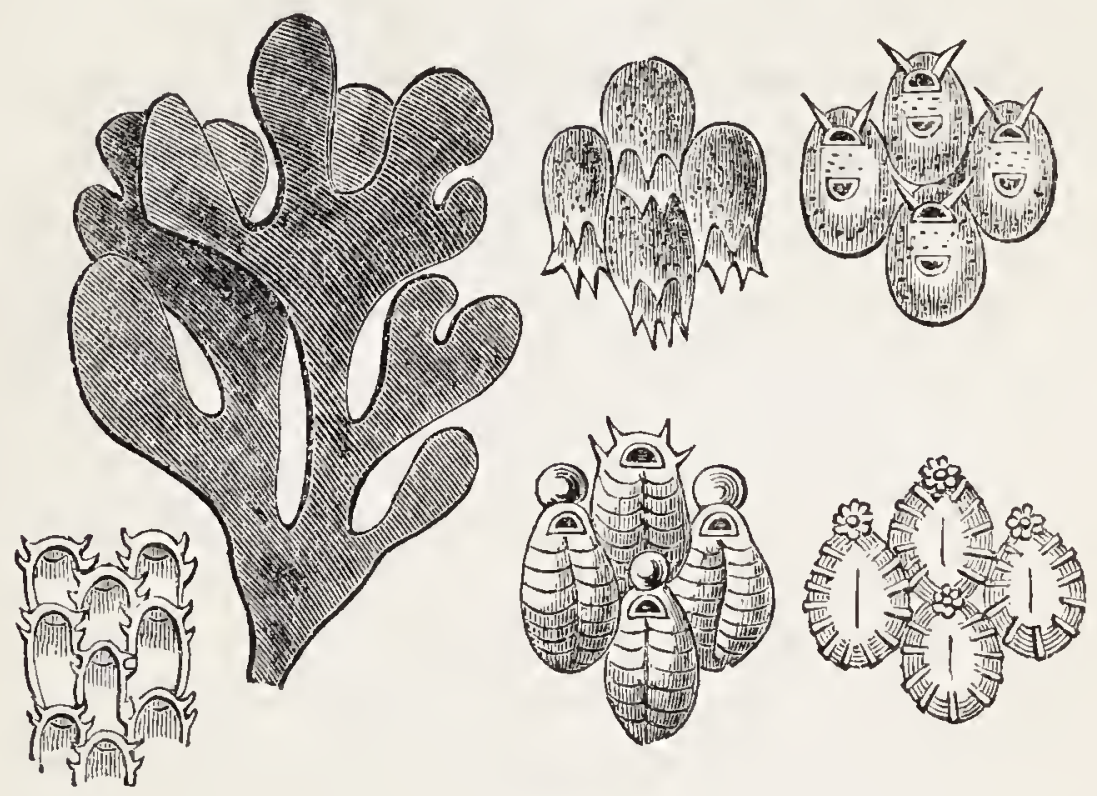

FLUSTRA, ETC.

CELLS OF FLUSTR杘 MAGNIFIED.

be distinctly seen. They are either found solitary, or in long chains, consisting of many similar individuals. These chains glide through the water with a regular, serpentine motion, as if a common will animated them, and yet each link is an independent animal, which continues to exist when the fraternity are fairly separated.

It is extraordinary that these creatures, apparently so varying, are the alternating generations of the same animal. The chain Salpæ exclusively go back to solitary Salpæ; and the latter produce only those which attach themselves to chains; or, as Chamisso, who first discovered this extraordinary process of development on his voyage round the world with Kotzebue, 
expresses himself: "A Salpa mother does not resemble her own daughter or mother, but her sister, her grand-daughter, and her grand-mother." When Chamisso first made hị discovery known to the scientific world, he was ridiculed as a visionary; but all later observations have not only fully confirmed his statement, but also discovered similar, or still more wondrous, metamorphoses in the Medusæ, Polypi, Sea Urchins, Crustaceans, and other lower marine animals. 


\section{CHAPTER IX.}

Asteroids: their Suckers; the Lrmphatic Systen.-Voracity of the Asteroids; tileir Power of Reproduction; their Metamorphoses.-The Comatul.e.-Brittle Stars.-Urasters. -Sun Stars.-Sea Urchins.-The Pedicellariæ.-House and Modth of the Sea Urchins-Holotilurie; their remiarkable Facurtit of mismembering thenselves.-Catching Trepangs off the Nortinern Coast of Australia.

"A $\mathrm{S}$ there are stars in heaven, so there are also stars in the sea." With this poetic allusion begins apothecary Links' folio volume on "The Asteroids," published at Leipzig in 1733, the first work exclusively devoted to this subject. We can hear the reader asking, How an inland apothecary could have performed this task, which was better adapted for a dweller on the coast? and regret that we cannot answer the query; so much is certain though, that, regarding the time when the book appeared, it contains much valuable information, and commences our literature of the sea in a praiseworthy manner.

The name given to these radiated beings is well sounding, but is full of deception. They do not shine like their celestial namesakes, nor are they distinguished from the other marine animals by any special merit; on the contrary, they occupy rather a low rank among them, and they only owe their name 
to their form, which resembles our traditional mode of representing a star.

But though they are inferior to most marine animals in many respects, and even the stupid oyster can boast of having a heart, which they do not possess; still, a closer inspection of their organisation shews us many most wondrous things, and teaches us, once again, that nature has set the seal of perfection also on the lowest and most simple beings.

We will assume that the external form of the Asteroids is known to our readers: the rayed structure; the handsomelycoloured back, frequently covered by spines of more or less fineness; the naked under-surface, with its rows of feet and feelers, which serve both for locomotion and for capturing food.

If you lay a Star Fish on its back, in a shallow vessel filled with salt water, the activity of these suckers affords a very interesting study. At first, the animal lies motionless, for the suckers have all been drawn in, in consequence of the rough treatment the fish has experienced, and only small tubercles are visible. Presently, however, they creep out like little worms, and after moving a while backwards and forwards in the water, as if reconnoitring the terrain, they bend down toward the bottom of the pan. Those which first reach it, attach themselves closely and draw the nearest after them, which adhere in a similar way, until their number is sufficiently large to be able to turn the Star over by their combined strength.

This expression of will, or, if you like it better, this welladapted employment of the feet to bring the body into its normal position, is certainly remarkable enough in so simple 
an animal, which possesses but very weak traces of a nervous system; but more wondrous still is the mechanism by which the feet are set in action.

Each of the small organs is tubular, and connected with a globular vesicle which is filled with a watery liquid. If the feet are to be protruded, a bladder at their base is compressed, and expels the water into the cavity, whose elongation depends on the degree of repletion. If they are to be withdrawn, the muscular skin of the feet is drawn up, and empties its contents into the vesicle.

In addition, the arms are divided into flexile limbs lying behind one another, whence they can be moved in every direction; so that they can be employed in the most various ways - to climb up marine plants, to crawl on the bed of the sea, and even for swimming.

On seeing a Star Fish lying so motionless at the bottom of the water, we should scarcely imagine that it was one of the most voracious animals, and an enormous destroyer of Oysters. It was formerly generally believed, that it watched the moment when the reckless Mollusc opened its shell, and by rapidly advancing an arm, took possession of the fortress; but it is not so. It does not make any lengthened siege, but embraces the closed Oyster, and brings its mouth in contact with the edge of the shell, which it covers with a stupefying or poisonous fluid, so that the powerless animal opens and falls a prey to its greedy foe, In consequence of the injury they do to the Oyster beds, in many places, the fishermen are forbidden to throw the Star Fish caught in their boats, back into the Sea, before killing them; but, in this case, what avails all the wisdom of the legislator? In vain may we cut off all the fine 
rays of the Asteroid, and cast the pieces into the sea, for each becomes in time a perfect Star Fish ; and you have created six new enemies in lieu of the one you fancied you had destroyed. The only method would be to drop the Asteroid into fresh water, when it dies immediately; but, even if hundreds of thousands were killed in this way, it would be of little use against an animal, which, in many places, covers the bed of the sea with a living carpet, and lays thousands of eggs annually. Hence we may leave the business of destroying the Asteroids to the voracious Crustaceans, Cephalopods, and fish, which remove them in countless numbers, young and old, and keep the entire race within proper limits.

We owe the knowledge of its maternal care, which would hardly be suspected in the Star Fish, to the celebrated Swedish naturalist, Sars, pastor of Floroe, who, though living in the high north, beyond the sixtieth degree of latitude, far from all zoological collections, libraries, and learned societies, constantly enriches science with the most remarkable discoveries connected with the lower marine animals.

It forms, namely, by bending the centre of the body and the rays, a closed sac, in which the eggs are hatched, and the young remain in it till they have grown a tolerable size. So long as the little fry cannot attach themselves firmly, the mother probably goes without any food, for the sac closes every access to the mouth, and they have been seen lying in this cramped position for eleven days. Equally wondrous are the metamorphoses of the new-born Star Fish, which, at this period, does not at all deserve its name, for it has an ovalcylindrical form, and floats about freely in the water by means of numerous cilia. Soon, however, suckers are formed at 

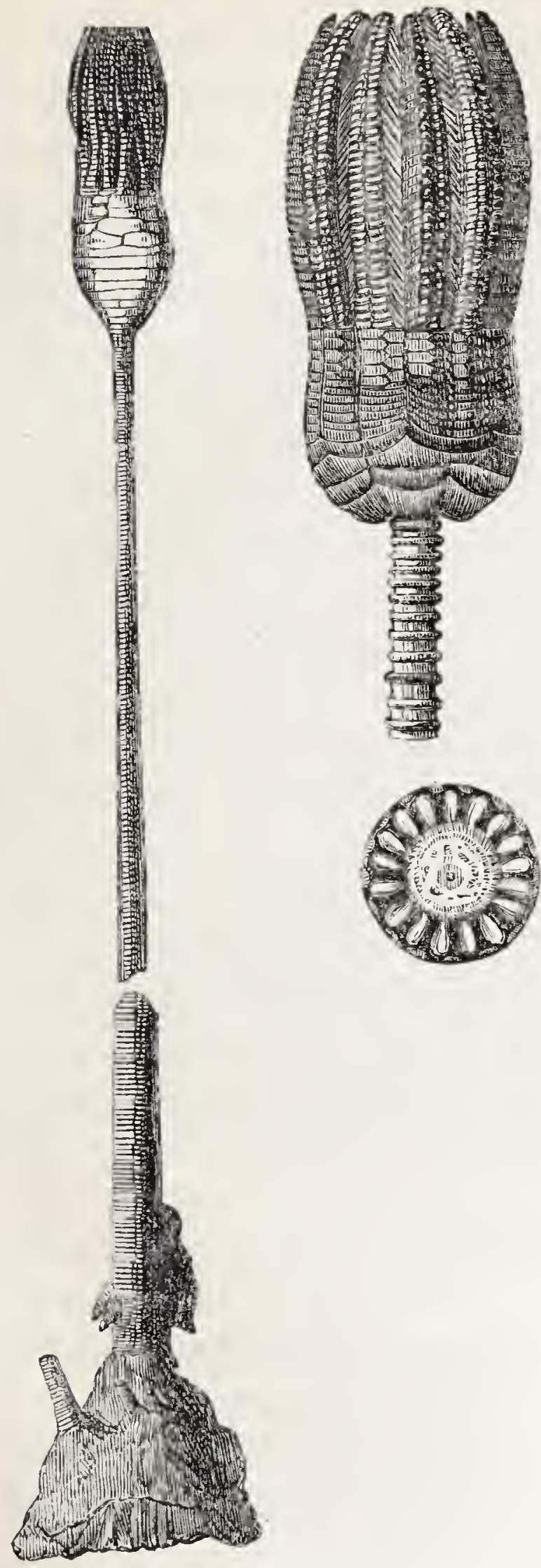

one extremity, in the shape of tubercles; and the little fish attaches itself to undergo its further changes quietly. Gradually it assumes a pentagonal shape at the other end. Five short stumpy arms grow out; as they become longer, the organs of suction are reduced, the cilia disappear, and, lastly, the young perfectly rayed Star Fish quits the paries

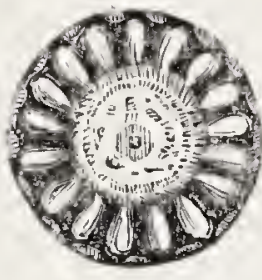
of the maternal body and goes on its travels. The whole of these wonderful processes occupies from six to seven weeks.

The Asteroids are found in every sea, and are divided into several families or groups, which again include numerous species. The primæval ocean also swarmed with Star Fish, which did not move like ours freely, but were attached to 
articulated stalks, and provided with branched arns. Entire beds of limestone are found, consisting principally of such petrified encrinites and pentacrinites, furnishing testimony of their former importance in creation. This family of feathered Star Fish, which holds so large a place in an earlier epoch of creation, is now erased from the book of life, except a few weak specimens; and, in our Northern Sea, is only represented by a single species, the Rosy Lily, or Feather Star (Comatula rosacec), which, with its long forked, finely plumed rays, is doubtlessly one of the handsomest of the whole family, and furnishes us with an idea of the splendour of the submarine landscape when the bed of the sea was covered with similar Asteroids. Strange to say, the Comatula during its early years is also attached to a footstalk, and does not proceed on its travels for some years, whence it may be assumed that the Encrinites, or Comatulæ of the primæval world, also enjoyed liberty of motion at a later age.

Mr. Thompson, of Belfast, whose name we have often mentioned, was the first to discover, in 1823 , a young stalked Comatula, which, however, less powerful than its primæval relations, only rises about three quarters of an inch above the ground. This find caused a great sensation among naturalists; for it was the only known living representative of a large perished family, the sole connecting link between the free surviving Asteroids of the present, and the sessile Asteroids of a long past age.

At first, the small stalked stranger was considered a separate creature, and christened Pentacrinus Europæus; but at a later date the original discoverer proved its perfect identity with the Comatula, by carefully comparing the most fully 
developed specimen of the stalked form with the youngest of those that move freely.

The Feather Star is met with from Norway to the Medi-

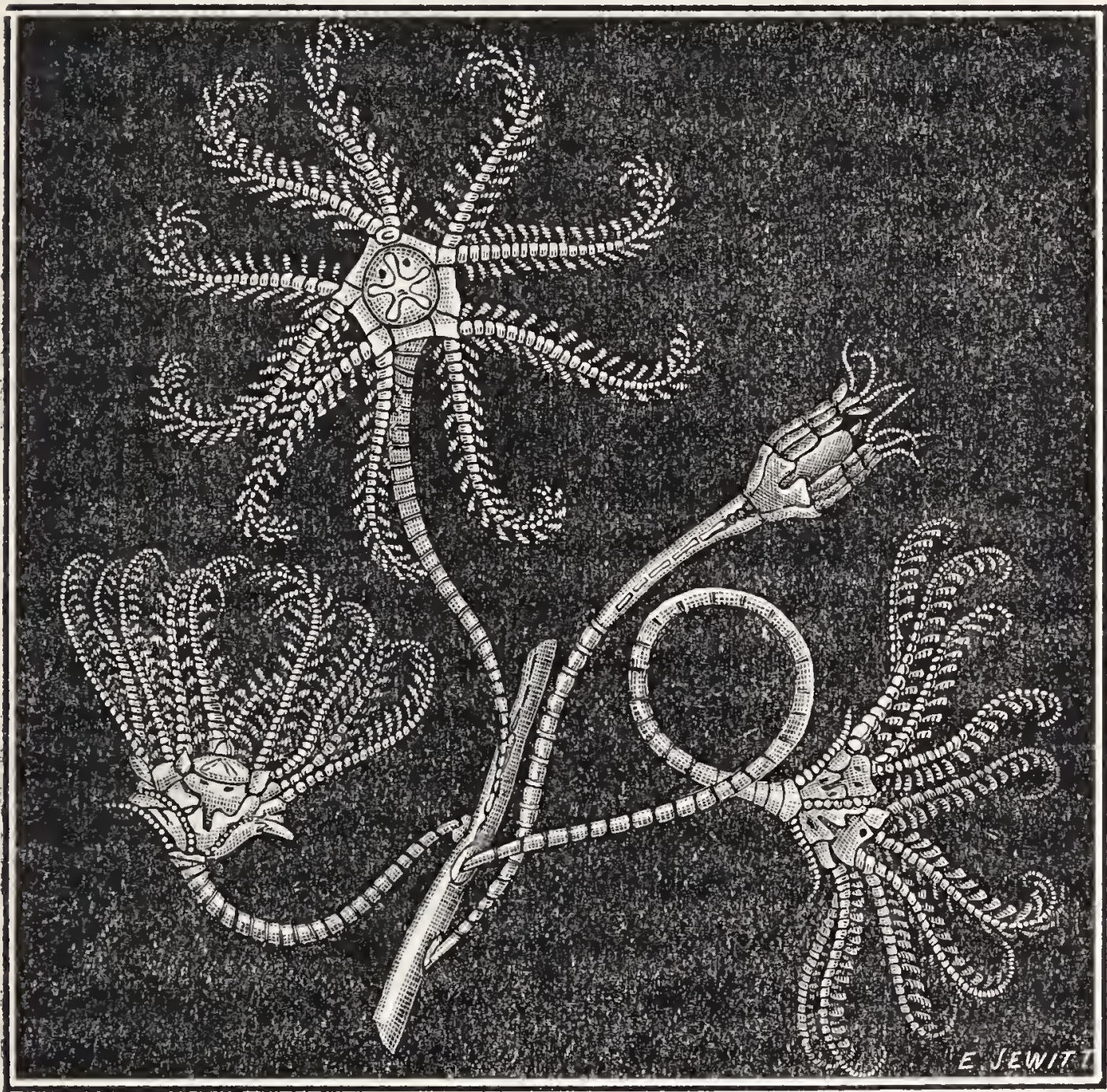

THE FEATHER STAR.

terranean, generally at a depth of ten to twenty fathoms. Its natatory movements resemble those of the Medusa, as it alternately projects and contracts its long plumed arms, and it darts up even more rapidly than the former animals, back first, from the depths. On being killed in soft water or spirits of wine, it dyes the liquid a handsome purple colour. 
The Brittle Stars or Ophiurids are principally distinguished from the Feather Star Fish by the structure of their worm-like rays, which are not, as in the former, excrescences from the body, but are attached so loosely to the small flat centre piece, that the animal can dismember itself at will. In the whole Ocean there is probably nothing more fragile. If a Brittle
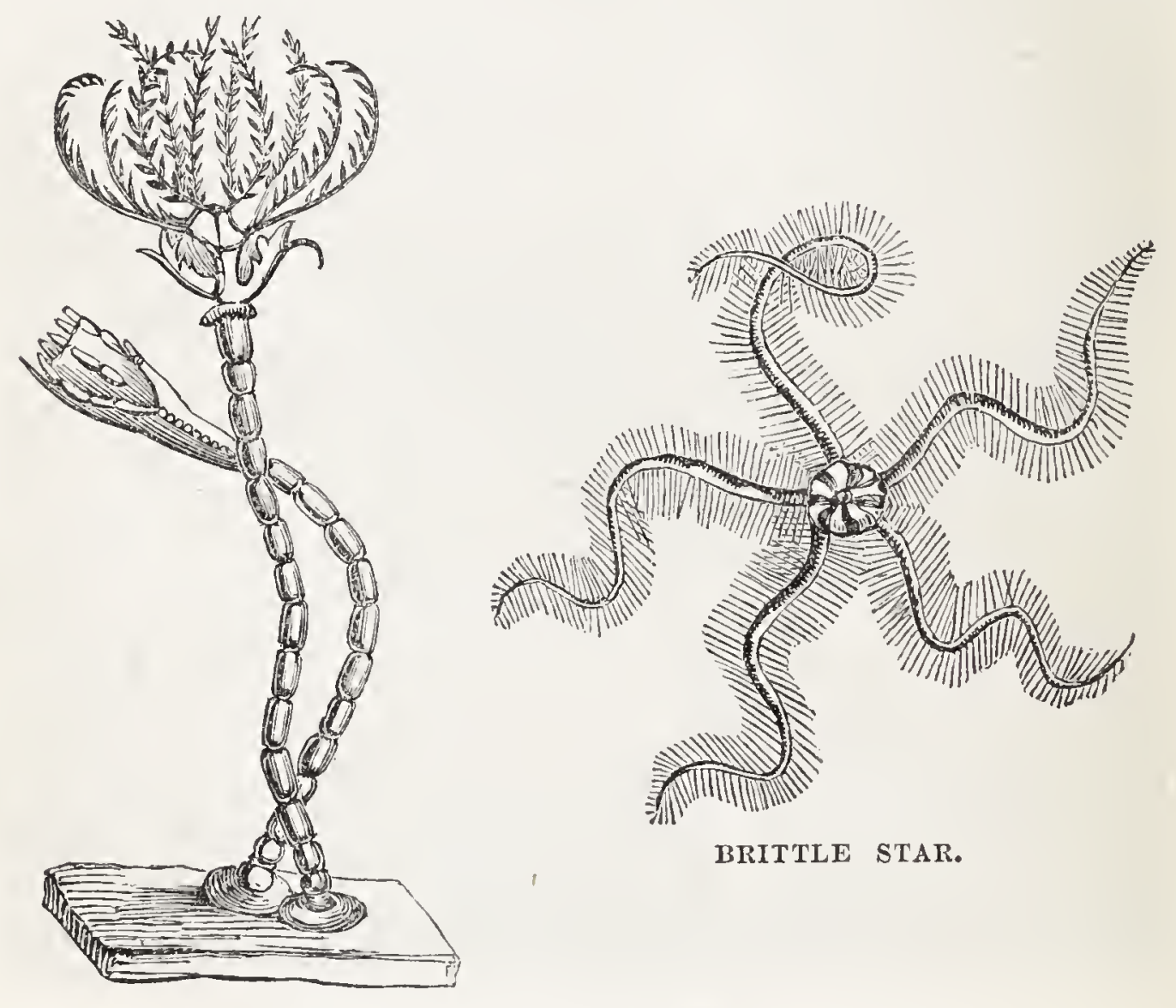

YOUNG OF COMATULA.

Star is merely touched, it immediately falls to pieces, and, if seized by the centre, throws off in a second all its arms, which it can replace by a wondrous power of reproduction. Thus it plays the curious naturalist many an amusing trick. The only way of keeping the Brittle Star whole, is to poison it so 
rapidly by dipping it in soft water, that it has no time to think about emancipating its members.

The thin, rounded thorn-covered arms of the Brittle Star have no suckers like the thick broad rays of the true Star Fish, and hence are not intended for crawling, but for swimming, which they do very rapidly. In some varieties, five undivided rays wind round the central piece; in the Medusa Stars, on the other hand, the rays are divided into several branches, so that a hairy net-work appears to surround the animal. To the Ophiuræ belongs the Ophiocoma rosula, the most brittle, but, at the same time, one of the handsomest varieties, which presents the most brilliant colours, blue, green, red, orange, etc., in a pleasant arrangement. The animal prefers those waters which flow over a rocky soil, and nowhere attains such a size as off the Shetland Islands. The Cod knows no greater dainty, and it is often found in the maw of that fish, which is evidently a mine of rare marine wonders. Among the Euryali, we notice the Scottish Argus (Astrophytum scutatum), which, with its out-spread Gorgon head attains a diameter of fourteen inches. When it goes in search of food, it stretches out all its arms, and drifts about in that position till a mouthful comes within its reach ; then, it draws them rapidly in, and the prey is captured in a close net.

There are four families of the Feather Star Fish noticeable in the German Ocean.

The Urasters are distinguished by the four rows of suckers projecting from each of the gutters, that furrow their arms longitudinally. The great number of these remarkable organs renders their lower surface strangely active. Hundreds of worm-like suckers, which bend in every direction, as if 
independently of each other, are more like a colony of Polypi, than belonging to the same animal. These fish are so sensitive, that, if only one be touched, all the others are alarmed.

To this family belongs the common Star-fish, or Four Fingers (Uraster rubens), which has long been accused of secreting from its skin an acid fluid which burns the fingers of the holder. The dingy red back is covered with prickly warts. On the English and French coasts they are found in such quantities as to be employed to manure the fields. Four francs are paid for the hectolitre, and 30,000 hectolitres have been caught in one year off Ostend. Hence the despised Star Fish produces no contemptible sum.

The Solasters, or Sun-stars, have only two rows of suckers in each furrow. Like the previous family, their back is rounded or arched. They are distinguished not only by the greater number of rays, which amount to fifteen in some, but also by the beauty of their skin. The whole back of the common Sun.star (Solaster papposus) is often of a splendid red or purple colour; at times merely the disc is red, and the rays spotted white and red. This voracious animal is found on all the coasts of Western Europe, and swallows Cyprex and Tops, as if it were a trifle to digest their hard shells.

The Goniasters have a more pentagonal form; while, finally, the Asteroids, in the stricter sense of the term, have a flat back.

'The Star Fish might be called a flattened Sea Urchin with propelling rays, or the latter a rolled-up Star, so great is the relationship between the two animals. In both cases, we find the radiated structure, in which the number five is so remark- 
able, as well as the rows of feelers, which, emerging from a centre are set in motion by a similar mechanism. Lastly, in both we find the surface of the body covered with small, numerous bivalved or trivalved pincers, which constantly move from one side to the other, and necessarily open and shut. These strange organs, which are known as the pedicellarix, are considered by some authors parasites, which only work

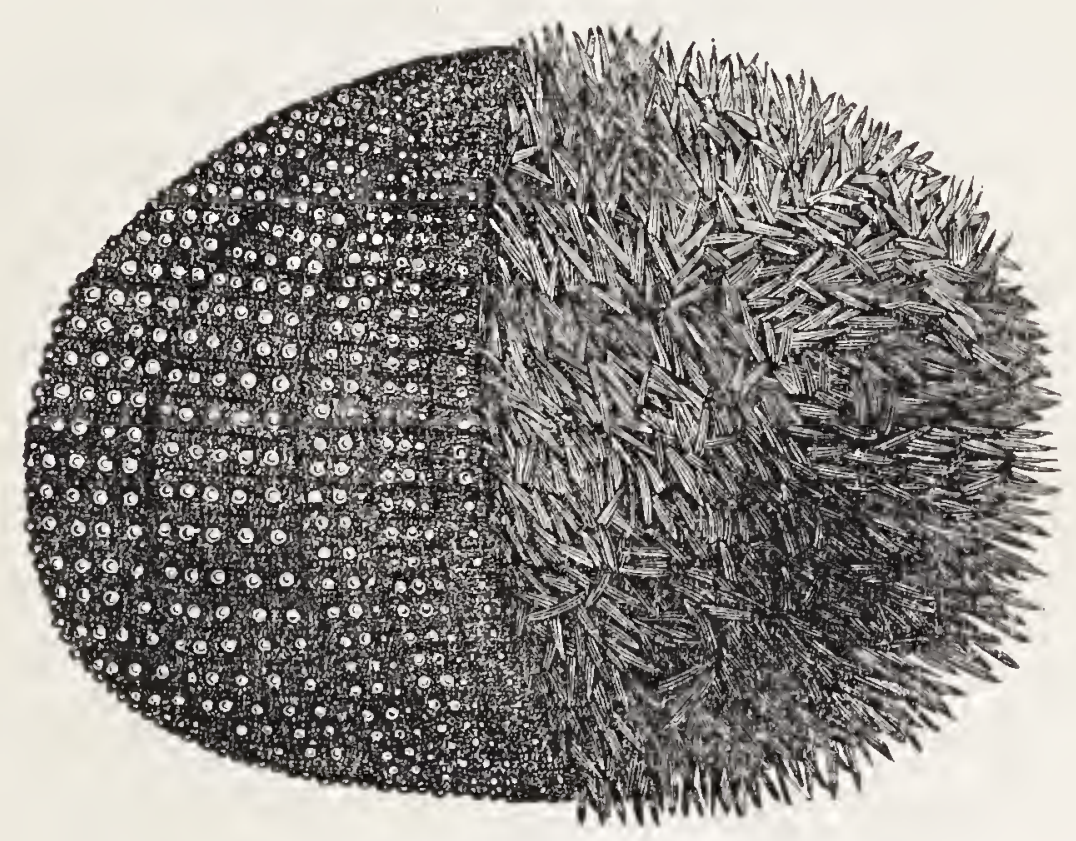

THE SEA URCHIN.

on their own account; but they are now generally regarded as organs aiding nourishment, which seize and convey to the mouth every floating substance that comes within their reach. Even in their external appearance, the Echinidiæ and Asteroids do not differ so extremely, as might be supposed when observing them side by side: indeed, both orders merge into each other by regular stages. Thus, among the Star-fish, the family of the Goniasters, in which the body rises in a cushion- 
shape, and the rays are much shortened, has a great approximation to the form of the Sea Urchin; and, in the latter, we also see a gradual transition from the flattened to the rounded forms. There are certainly distinctions between the

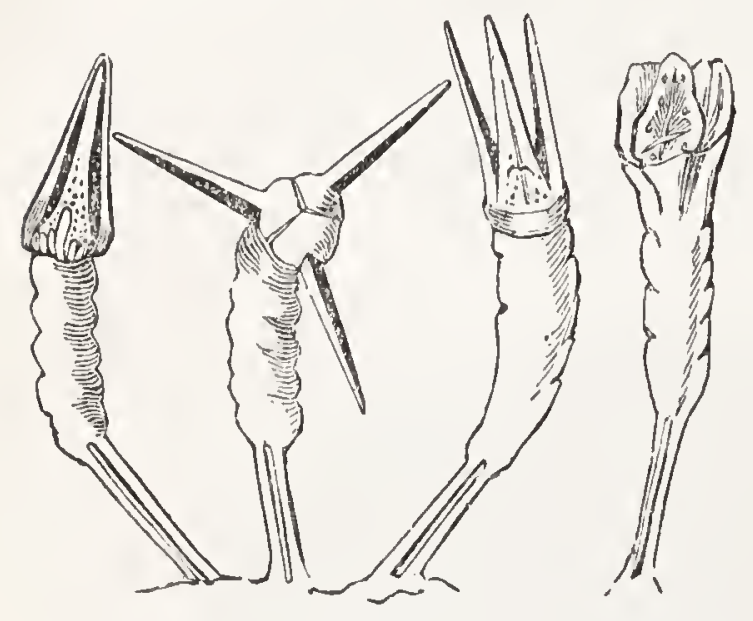

PEDICELLARIA. two aninials. Thus, in the Sea Urchin, the organs of digestion form a tube provided with two openings; while, in the Stars, they consist of a sac, with only one ex. ternal orifice. Their mode of life is precisely the same. The motion of the Sea-Urchin, like that of the crawling Star-fish, is produced by attaching the feelers, and dragging the body after them. The moveable spines with which they are covered, do not appear to be employed as supporters, but serve to dig into the fine sand, where the $\mathrm{Ur}_{\mathrm{r}} \mathrm{chin}$ is more secure against the attacks of its enemies.

Many varieties inhabit holes or excavations in the rock, adapted to their size, and evidently formed by themselves. Bennett describes the abode of the Echinus lividus as circular, and sufficiently deep to receive two-thirds of the animal: in this hole it attaches itself so firmly with its suckers that it is difficult to drag it out alive. On the coast of County Clare, thousands may be seen buried in the lime-stone; and their purple, shiny, and regular shape forms a handsome carpet on. the grayish bed of the sea.

It is not yet quite clear in what way the boring is effected. 
It seems as if the teeth begin the operation, and that then the rock is dissolved by some acid secretion.

Sea Urchins are found in every sea; but as they are difficult to preserve, and many of them have such long and delicate spines that it is almost impossible to obtain perfect specimens, in all probability not the tenth part of their varieties is known to us.

The calcareous dwelling of the Sea-Urchin appears at the first glance a simple shell, and not deserving further notice; but, on closer examination, it proves to be a masterpiece of mosaic, composed of several hundred pentagonal plates. Their connection is so perfect, that the lines of junction are scarcely noticeable; but if the shell is laid for a few days in fresh water it will fall asunder. This complicated structure must not be regarded as a useless architectural luxury; but it is, indeed, highly necessary in order to allow for the animal's growth. A simple hard covering would have been incapable of further expansion, and only a composite shell like that of the Urchin, could, by continuous deposits on the edges of the several plates, allow the shell to increase with the growth of the body. If we examine a living Urchin, we find that the entire surface of the shell and the spines is covered with a tender membrane, which sinks into the space between the several plates in spite of their close connection. It is this membrane which secretes the carbonate of lime of which the shell is composed, and deposits one layer after the other on the edges of the several plates, so that in this way the whole structure continually increases, till the animal has attained its full growth. The spines are secreted in the same way, and display under the microscope an admirably beautiful and 
regular structure. So paternally has the Great Architect of the Universe provided for the wretched Sea Urchin!

The mouth of this animal - known as the lanthorn of Aristotle - is a masterpiece in its way. Imagine four triangular jaws, each supplied with a long moveable tooth, projecting from the mouth. A complicated muscular system sets this artistic apparatus in motion, draws the jaws together, or moves them up and down on each other; so that the cleverest mechanician would have a difficulty in inventing a better crushing instrument. The mouth of the Sea Star, though bearing some resemblance, is much more simple.

The Holothuriæ, or Sea Cucumbers, belong to the same animal class as the rayed Star Fish, and the circular Sea Urchin. The hard calcareous shell is here absent, and the

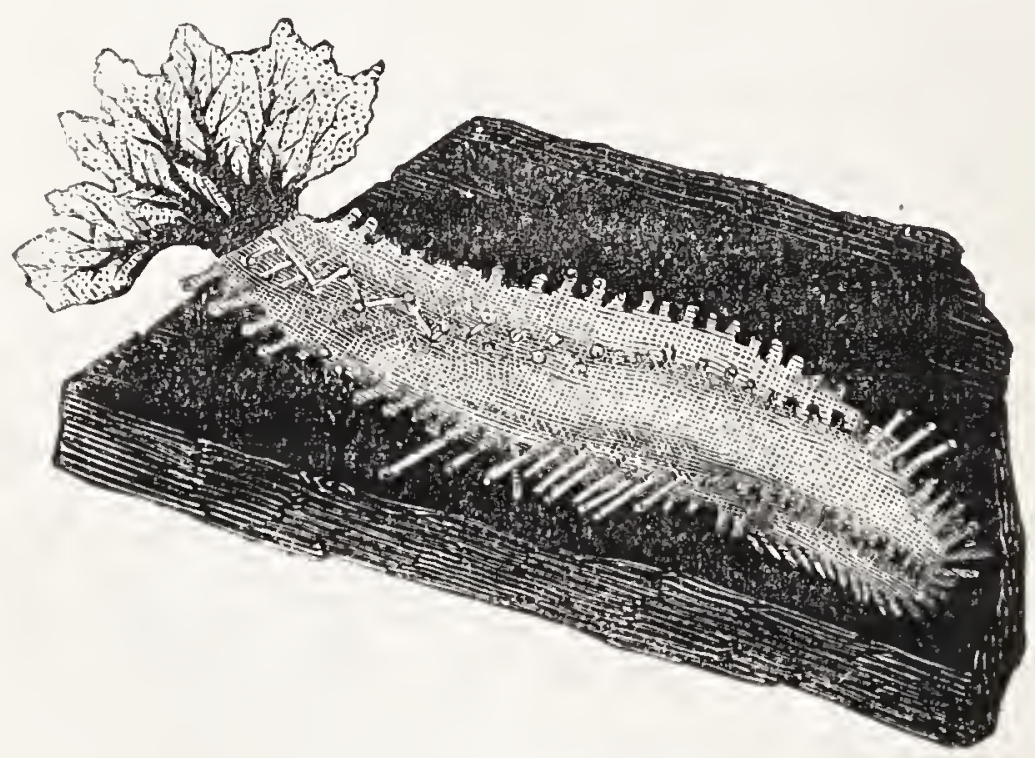

TIE SEA CUCUMBER.

lengthened form of the posteriorly-pointed body, as well as the garland of feathery tentacles which surround the mouth, allow no resemblance to be traced; but the relationship is clearly visible in the suckers, which, in some varieties of the 
Holuthurix, are arrayed in fifty-two rows; in others, irregularly scattered over the whole body. By the aid of these organs, the animal moves; but it can also swim or crawl, like worms, by the alternate contraction and dilatation of the body.

The great European Sea Cucumber, which, when at rest, is only about a foot in length, can make itself thrice this size; and, indeed, changes its form in the most remarkable manner: being at times elongated, like an annelid; then, again, contracted at the centre, like an hour-glass; or puffed up into a perfect globe, like a real bladder.

Under the influence of terror, probably the only emotion of which it is capable, the Holothuria dismembers itself in a very peculiar way. As its external form does not allow of an arm or leg being thrown off, as we found in the Brittle Stars, it expels its entrails without ceremony, and lives very comfortably without a stomach, which is certainly a greater marvel than if it lost its head; for there are many men who do not seem to feel the want of that part of the body.

According to Sir James Dalyell, all the lost parts are gradually regenerated, even in cases where the disembowelling process is carried so far that only an empty sac remains. Sea Cucumbers are frequently caught, in which the internal parts are more or less deficient, and the process of regeneration is going on in them.

Considering this facility of getting rid of its interior, it is the more remarkable, that the large Pine-apple Holothuria puts up with the presence of a very strange parasite. This is a fish, about six inches in length, which Mertens and other naturalists frequently met with in it. This impudent fellow, 
which sees badly, and shuns the light, creeps into the mouth of the great Sea Cucumber; and, as the stomach is too small for its reception, it tears asunder the alimentary duct, and quarters itself between the intestines and the outer covering. Two of these fish have been found together in one Sea Cucumber, and there was not the slightest external sign to evidence their presence, nor did the host appear to suffer from it in any way.

The Holothuriæ, which in our hemisphere are little noticed, and are not at all used, play a much more important part in the Indian Ocean, where they are caught by millions, and taken to the markets of China and Cochin China, where they are known by the name of Trepang. Thousands of prahus are annually equipped in the ports of the Sunda Islands for the capture of Holothuriæ, which, by the aid of the western monsoon, examine the sea between the Moluccas, the Philippines, and the Ladrones, or sail up the north coast of New Holland, and being afterwards favoured by the eastern monsoon, return home by the same route. The bays of this inhospitable, treeless land, are enlivened for some months in the year by the presence of the Trepang fishers.

"During my excursion round Raffles' Bay," Dumont d'Urville tells us, in his "Voyage au Pole Sud," "I had noticed, here and there, small walls enclosing a circle. The meaning of these low buildings remained an utter mystery to me, till the Malay fishermen arrived. The prahus had scarce cast anchor, ere large cauldrons, about three feet in diameter, were brought ashore, and were placed on the small walls, whose object now became evident to me. Near these improvised fire-places they then built huts, consisting of four 
bamboo poles covered by a roof, under which the Holothurix would probably be dried in damp weather. By nightfall, all the preparations were completed; and the next morning we visited the fishermen, who received us politely. Each prahu had thirty-seven men aboard, and carried six boats, all of which we found busy fishing, partly near the anchored prabu. Seven or eight nearly naked men dive to seek the Trepang at

bottom of the sea. A burning sun scorched the dripping heads of the divers without injuring them, though no European would be able to endure such a life for a month. It was about midday, and the Malay captain assured us this was the most favourable time for fishing. We also saw the divers coming regularly to the surface with some captured Holothuria. It appears, that the higher the sun stands, the more easily the animals crawling along the bottom can be seen and caught. They had scarce thrown their booty into the boat, than they dived again directly. As soon as a boat was sufficiently laden, its place was taken by an empty one. I went on shore in one of them, to see the preparation of the Trepang.

"The Holothuria of Raffles' Bay is from five to six inches long, and about two inches in dianeter. It forms a cylindrical fleshy mass, on which no external signs of any organ can be noticed. It lives on the bed of the sea; and as it can only crawl very slowly, it is easily caught. The first quality of a good fisherman is to dive well, and have a sharp eye to distinguish the Holothurix from the similarly coloured ground.

"The Trepang is prepared for market by throwing the still living animal into a kettle of boiling-hot water, in which it is constantly kept in motion by a long pole, which rests on 
a fork fastened in the ground. 'The first operation of boiling is over in a few minutes, after which the Holothuria is removed from its hot bath and split up the belly, for the purpose of removing the entrails. It is then thrown into a second cauldron, in which there is a small quantity of water; and the bark of a mimosa carbonizing in the fire, produces a dense vapour. The object of this treatment is to smoke the Trepang, so that it may be better kept. Finally, it is dried in the sun.

"I tasted the Trepang, and found it to resemble the lobster in taste. It is carried to the Chinese markets, and, as I heard, the picul of $25 \mathrm{lbs}$. is sold by the Malays to the dealers for 15 rupees. The captain estimated his cargo at about $£ 120$, which he had collected in three months. From the remotest periods, the Malays have held the monopoly of this trade; and the Europeans will never deprive them of it, for the economy of their equipment and their extraordinary frugality forbid any rivalry.

"By about 4 p.m., the Malays struck work. In less than half an hour, cauldrons and instruments were again carried aboard, and the same evening the prahus disappeared from our sight."

The inhabitants of the Waigiou Island, to the north of New Guinea, prepare the esculent Holothuriæ in the Malay fashion, and barter them for cotton and wool stuffs, which are brought there by some Chinese junks. "In every hut," Lesson says, "we found large piles of this aried leathery substance, which is not very pleasant eating, and is only esteemed by the Chinese because they ascribe to it, as to the other favourite gelatinous stuffs - the agar-agar, the shark fins, and the 
edible bird's-nest - a peculiar strengthening power, and hope by its aid to prepare their bodies, weakened by sensual enjoyments, for new excesses."

The inhtibitants of the Feejee Islands have the character of being the greatest cannibals and most perfidious savages in the whole of the South Seas. Still, the Trepang Fishery carries many an American or European sea-farer to that dangerous archipelago. Wilkes ("United States' Exploring Expedition") found there a countryman, a Captain Eagleston, who had often made the voyage, and explained to him the way in which the trade is carried on. The first thing a foreign speculator does is to make a bargain with one of the chiefs. The latter undertakes to build a house for drying the Holothuriæ, and orders his vassals to fish or dive; for the best variety is found in depths of six to twelve feet, while the poorer sort is caught at ebb-tide crawling about the reef.

Not only by day, but also by moon or torch-light-so great is the transparency of those crystalline waters-the animals are captured on the coral bed, as at this time they go about in search of food. The usual price paid a chief for a cask of fresh Trepangs, is a sperm whale-tooth; but musquets, gunpowder, bullets, vermilion, glass beads, and blue calico, are also taken in payment. After the animals have been split open, they are thrown into large pots, where they stew for half an hour in their own gravy: they are then strained, and, lastly, carried into a drying-house, where they remain for several days over a slow fire. It may be conceived that such a task, in the parching tropics, is not one of the most agreeable; but the chief troubles himself as little about that as a planter does whether his slaves like cutting sugar-canes. In 
this way Captain Eagleston had, in seven months, and with an outlay of about 3,000 dollars, collected a cargo of 1,200 piculs, which he expected to sell at Canton for 25,000 dollars. In addition, he had tortoise-shell on board worth 6,000 dollars. It is not a bad trade, then; but it is connected with such dangers that no one will underwrite a ship bound for the Feejee Islands. To succeed, the captain needs activity and courage, the most perfect knowledge of the character of the savages, the most extreme caution and foresight. No large canoe must be permitted to lie alongside the vessel; and a chief must always remain on board as hostage. The savages try to seize smaller vessels by swimming under water and cutting the cable when the wind blows on shore; or fastening a cord to the chain, by which they drag the vessel ashore. According to the law of the country, all jetsom belongs to the king. The crew are murdered and devoured. 
JELLY FISH.

\section{CHAPTER X.}

Structure of the Jet.ly Fish. - The Disc, or Pulmonigrade Jelly Fish: how do they move?-Rhyzostoms. - Meduse.Ribbed, or Ciliograde Jelly Fish.-The Cydippe In:undibulum.-The Physograde or Tubular Jelly Fish.-Socialistic Ocean Republics.-The Velelle.-The Caravel, or Portuguese Man of War.-Story of a Peruvian Sailor.

MONG the living wonders of the Ocean, is also the transparent, gelatinous army of Jelly Fish, or Acalephæ, whose innumerable bands frequently astound the navigator, when his vessel, impelled by light breezes, marks its rapidly disappearing furrow for days together through thickly composed masses of bell-shaped Medusæ, or brilliantly-coloured Physophoræ.

Not alone their countless numbers, the variety of their forms, and the splendid colouring which makes many of them true pearls of the sea; but, above all, their remarkable structure and strange process of development, are well adapted to recommend the Jelly Fish to our attention.

In walking along the beach, and noticing a Medusa left by the tide, we must not precipitately conclude that it is a disgusting gelatinous mass, which demands no further attention; for this shapeless mass was lovely and graceful so long as it swam about in its natural element: and its simple organisation 
evidences the masterhand of the Creator equally with that of the more highly gifted animals.

Contempt is, in most cases, a bad teacher: it therefore seeks and does not find, while a rich reward awaits the attentive observer, who, with pious confidence, hopes to discover some marvels even in the apparently lowest and poorest things that Nature produces.

Had the naturalists of our days thought like Reaumur, who considered the Medusæ a species of living jelly (gelée vivante), about whose internal structure no one need care, we should assuredly have been poorer by many an interesting discovery. Duméril was of a different opinion: he squirted milk into the mouth of the Medusæ, and saw the fluid extending through channels which were arranged with almost mathematical regularity. Other observers then turned their attention to these neglected creatures; and, lo! the structure of these animals, once considered so simple, appeared the more complicated the closer the acquaintance with it became. Organs of digestion and reproduction were found, vascular systems, artistic apparatus for catching food and motion, until, finally, Professor Ehrenberg proved the existence of nerves and of organs of sensation in the Acalephæ.

All this seems the more remarkable, when we reflect that the Jelly Fish are composed almost entirely of water, and dissolve into nothingness when their life has gone. Of a Medusa weighing from 20 to $30 \mathrm{lbs}$., which dies on the beach, within a short period only a few traces remain, which cover the ground like a light varnish: all the rest is swallowed by the thirsty sand.

The genera of Jelly Fish, which extend from almost 
microscopic size to the diameter of two feet and upwards, in a long succession of families and varieties, inhabit both the arctic and tropical seas. In them, too, the reflection of the bright sunlight, which, in the equatorial regions, endows the whole animal world with brightest colours, is also seen; for while the Medusæ of our seas are principally dull and lustreless, like the waters in which they live, the Medusæ of the tropical zone appear in all the glory of the azure, golden, or ruby tints, with which the ocean adorns them. In stormy weather, these tender, gelatinous animals, which cannot stand the fury of the waves, sink to those deeper regions which the hurricane cannot affect; but so soon as a calm sets in again, they once more rise to the surface of the water, and delight the eye of the traveller who is sailing over the tropical seas.

The Jelly Fish are of no immediate value to us. All the classes of animals inhabiting the sea, which we have as yet examined, from the Ocean Mammalia down to the Holothurix, even corals, algæ, and sponges, man makes serviceable to his numerous wants; but the Acalephæ, consisting almost entirely of water, traverse the sea, having no reason to fear his gluttony or greed, and seem in no way to affect him. But the immediate benefit he derives from them is far from inconsider. able. They in fact supply the food of the gigantic Whale, and are converted into oil, which entices thousands of bold sailors to the desolate Arctic Ocean; countless Crustaceans and Molluscs live on them, and in their turn are devoured by the schools of herrings, whose capture employs and enriches entire nations. They, too, produce principally the glorious phenomenon of marine phosphorescence; were it not for the Mammaria Scintillans, one of its smallest representatives, the German 
Ocean would not shine, and one of the most wonderful natural processes would no longer delight us on its shores.

The Acalephr are subdivided into the disked, ribbed, and tubed Jelly Fish. Although many large varieties are not strange to the European seas, and some are frequently noticed on our coasts, formerly they were only imperfectly investigated and those of the tropical specimens unknown. We owe a more perfect knowledge of them to more recent travellers, such as Quoy and Gaymard, Ehrenberg, etc.

The disked or pulmonigrade Jelly Fish are distinguished by their umbrella-shaped, generally transparent body; from whose lower concave side, hang more or less deeply fringed vessels and long thread-like tentacles round the mouth. Such an animal resembles an animated crystalline mushroom, with its stalk and gills. The tentacles, though they seem so trifling, are terrible weapons against all the small marine creatures which come in contact with them. Like the tentacles of the Polypi, which we shall presently describe, they are armed with countless small needle-shaped weapons, which not only wound, but also poison by emitting an acrid fluid, and deprive the stunned animal of all power of resistance. Some varieties produce a burning sensation, even on a man's hand, which at times attains to inflammation, whence they are also called Sea-nettles.

The Disked Medusæ move by alternately contracting and expanding the umbelliferous body. The effect of this motion, which is produced by muscular fibres, is a strong pressure on the water beneath, which raises the body and moves it according to the variation of the pressure. The convex end 
'is always directed forward, while its concave mouth surface, with its numerous appendages, is turned behind.

Among the most remarkable Disked Medusæ, and which are most frequently found on our coast, are the Rhizostoms, which attain a diameter of two feet, and weigh from twenty to thirty pounds. The Rhizostoma Cuvieri is generally millkwhite, pellucid, often of a corn-flower blue in parts, but at times entirely blue. The edges of the disc are always very handsome, with a violet tinge. It is very gregarious; and all swim together in one direction. On touching one, you feel a very unpleasant and long lasting pricking. In this variety the tentacula on the edge of the disc are absent; and eight arms in the centre are converted into one common stalk. The structure of the mouth displays a remarkable anomaly, for the usual central orifice is missing, while the arms are traversed by separate canals

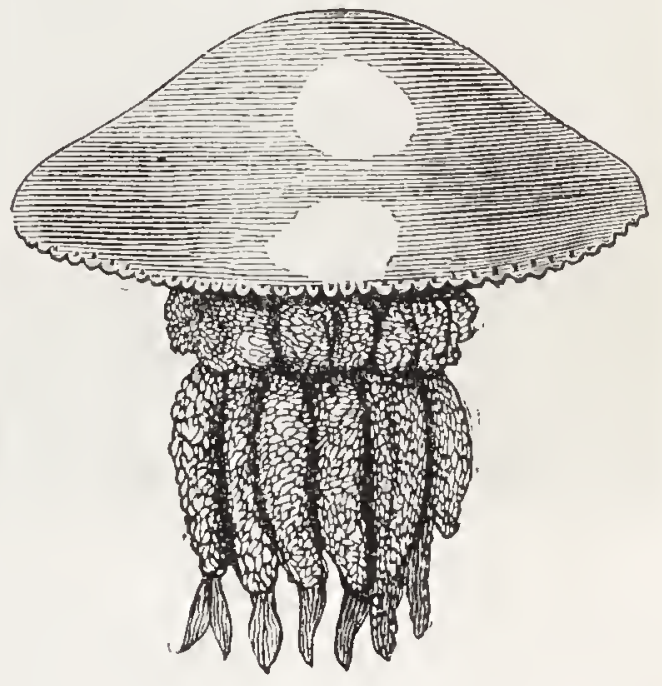

RHIZOSTOMA. opening direct into the centre of the body, and terminating at the end in numerous small openings. Through these, the food is received, which must always consist of very small animals. The true Medusæ, on the other hand, are supplied with a large central mouth on the lower side of the disc, which leads direct into the abdomen. The ribbed or ciliograde Jelly Fish are distinguished from the above only by their external globular 
or oval shape, and by the peculiar structure of the organs of motion and capture.

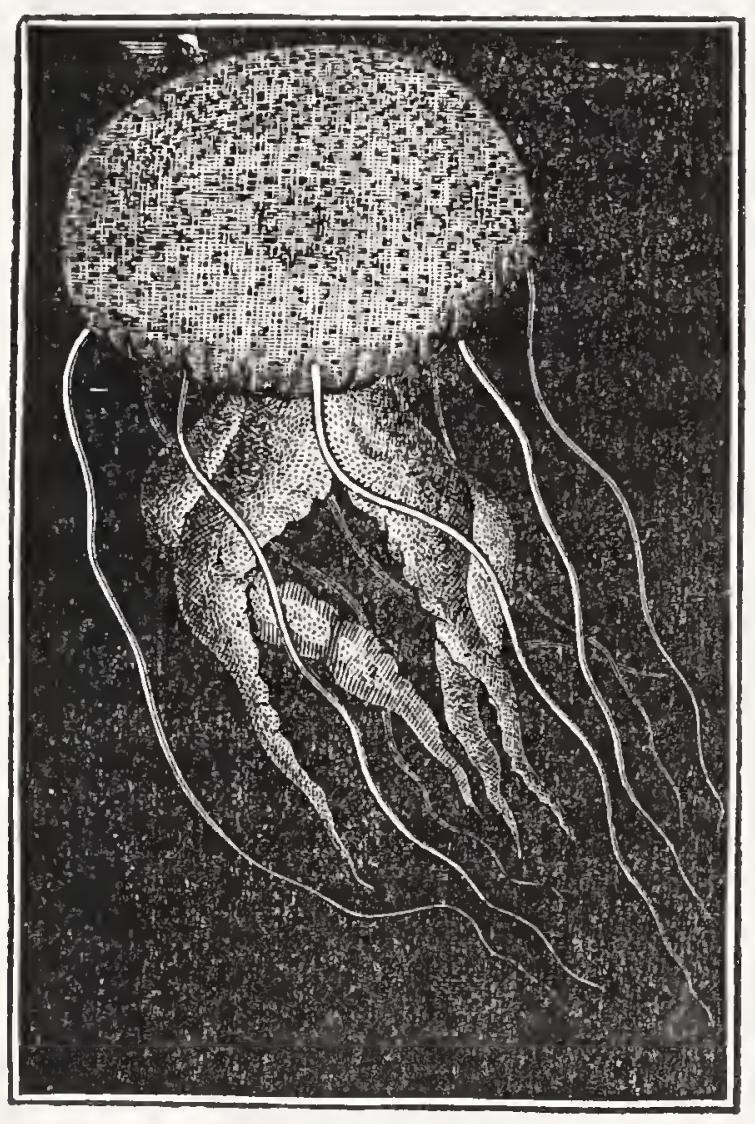

CYDIPPE.

The graceful Cydippe infundibulum, which is frequently found in summer on the coasts of the German ocean, is the best known variety. The melon-shaped body of the size of a hen's egg, is clear as crystal, and divided into eight folds of equal size by the same number of ribs standing equidistant from each other. These ribs are covered with countless flat small shovels, which lie over one another and obey the will of the animal. If the Cydippe wish to swim backwards or forwards, it places all these instruments in motion, whose united strength drives the living crystal pleasantly and gracefully through the water; if it wish to turn, it checks the shovels on one side of the body, while the others continue working.

The fishing apparatus of the Cydippe is no less gracefully arranged than the structure of its organs of motion. It consists of long delicate tentacles projecting from the lower side of the body, capable of such extraordinary contraction, 
that they can be entirely withdrawn into the channel whence they spring. Along one side, and at regular intervals, they are covered with a quantity of shorter and much thinner filaments, which, when the tentacles are drawn in, roll up in a spiral form, and gradually extend on being drawn out. At the extremity, these filaments have a sucking apparatus, and the external end of each tentacle also appears to terminate in a sucker.

They extend to an incredib e length, and it is difficult to understand where they come from. They do not sting, but attach themselves closely to the finger, and can then be drawn out for several inches.

This remarkable fishing apparatus is wanting in the Beroë, which has a wide mouth, constantly open for swallowing, by which to procure its food. The Cydippes and Beroës can be preserved for a short time in a large vessel filled with sea water ; but they soon die and melt away into nothing. Hence there must be in the sea, some unknown mysterious powers, indispensable for the existence of many animals, which are lost in an isolated aquarium. Number Four plays as remarkable a part among the Medusæ, as Five does in the Echinidiæ and Star Fish. All parts of the body are divisible by four, and arranged in a radiated form round the centre.

Among the strangest of existing animals are indubitably the Tubed Jelly Fish, or Siphonophoræ, formerly regarded as perfectly developed or independent, but which, as the later investigations of Sars and others have shown, are only the highest types of the countless different families of Medusæ. They are composite creatures, true colonies or socialistic republics, where one portion of the individuals is destined 
exclusively for motion, while another larger portion has undertaken the duty of providing the entire hive with the necessary food, as well as producing the young perfect disc Jelly Fish. 'The Siphonophoræ themselves, are formed of the simple larvæ or eggs of the Medusæ, which develop themselves, just as the plant produces its buds. The generations of the Medusæ alternate like those of the Salpæ, so that the young one resembles its grand parents, but not its father and mother.

Other marvels have been taught us by the observation of these lower marine creatures; it has been found that the pretty, plant.like, tenderly plumed forms of the Serpulariæ, Plumularix, and other Hydroids, formerly counted among Polypi, equally issue from the larvæ of the naked-eyed Medusæ (chiefly the Cryptocarpa Eschholzii), and eventually become perfect Jelly Fish. They are, therefore, nothing further than sessile nurses, just as the Siphonophoræ are nurses swimming about freely. How remarkable is this close relationship, or rather identity of being among creatures, whose external shape varies so greatly, and what a triumph for the human spirit of investigation to have reconciled these hidden mysteries of ocean !

The Tubed Jelly Fish are so strangely formed, that no description could possibly furnish an idea of them; in the same way as no artist could depict their crystal transparency and their brilliant colouring. Thus, in the Diphyæ, the long body consists of two pieces of cartilage of unequal size; fitted into each other; the anterior attached to a thread with numerous suckers, the posterior fastened loosely to it; while the Stephanomix represent long chains of polished diamonds, some of which form 
natatory bladders; the others fishing apparatus with numerous tentacles and suckers. At the slightest shock the loosely connected members separate and drift on the surface of the water, where they probably, like other Polypi, form a perfect state in process of time.

Among the Tube Medusæ is also classed the pleasing Velella. The long transparent body is covered with deep blue spots, a thin pellucid plate rises vertically from the back, and catches the favouring breeze; numerous dark blue tentacles or cilia hang down from the lower surface of the body, and allow the little animal to change its direction, perhaps, serving as oars when the calm' renders its sail useless. An internal hairy skeleton, of extremely light and spongy nature, and filled with air cells, gives the body some consistence, and seems like the natatory bladder in fish, to aid it in rising and sinking.

The Velellæ have a very extended geographical range. Their chief abode appears to be in the warm regions of ocean, but they are frequently drifted by the currents to higher latitudes. Countless Velellæ which the gulf stream has probably carried, are thrown on the western shore of Ireland, especially in summer and autumn. These poor defenceless creatures are incessantly pursued by Crustaceans, who devour all the soft parts, so that at last only the paper-like skeleton drifts about in the water.

The Velellæ are far surpassed in beauty and size by the Physalix, or Sea-bladders, which are also principally found in the hot zone. The Physalia Caravella, or Portuguese Man-o'War, is the most astonishing of all this class, through the brilliancy of its hues. From a bladder a foot in length and three 
inches broad, whose pellucid glass glistens with purple, violet, and bright blue tints, rises a vertical crest, the topmost edge of which is a burning red. From the stomach depend countless short suckers; and between them hang long threads, like the tresses of the Medusa's head, in curly, splendidly coloured red and violet locks. The fishing lines can be rolled up at will, or sent out from fifteen to twenty feet with astounding velocity.

In swimming, the Physalia drags them after it like a long net, and so soon as they touch a fish, which fancies itself safe at such a distance, or a carelessly floating Cephalopod, they surround it with lightning speed, and check all resistance by the poisonous juice that emerges from their funnel-shaped tubercles. In this way the Physalia devours many a Bonita or flying Exocete, which far surpasses it in size. But it is not only terrible to the denizens of the sea, but also punishes a man who seizes it carelessly or ignorantly by producing violent pain. The skin grows red and rises in large blisters.

"One day," Dutertre tells us in his Histoire des Antilles, " when I was pulling about in a small boat, I saw a SeaBladder, and, as I was curious to examine its form more closely, I tried to seize it. But my hand had scarce approached it, ere a network of filaments surrounded it; and, after the first cold feeling, I felt as if I had thrust my arm up to the shoulder in a kettle of boiling oil."

"During the first voyage of the Princess Louise round the world," Meyen says, " and when near the equator, a very large and beautiful Portuguese Man-c'-War drifted past the ship. A young sailor, of remarkable courage and great daring, leapt naked into the sea to capture the animal: he swam up and 
seized it; but, at this moment, it threw its long suckers, extending for three feet from its body, round the naked swimmer. 'The young man, being terribly alarmed at this, and probably also feeling the burning pain over the whole of his body, shrieked for help, and had scarce strength to reach the ship's side and be drawn up. The animal was immediately torn from him, and his skin washed, but the pain and inflammation had grown so severe that a brain fever set in, and there was a doubt as to his eventual recovery." 


\section{CHAPTER XI.}

Poltpes. - Sea Anemones. - Lrthophytes, or Stone Corals. -Corat Reefs, Barren Reefs, Encircling Reefs, Shore Reefs, Fringing Reefs; Atolls, Lagoon Islands: their formation, according to Darwin. - How do Coral Reefs become the Abode of Man?-Coral Fishing in the Mediterranean.

THE land has its flowers: they adorn our gardens; they exhale their fragrance on the skirts of the woods; they defy the winds, which blow around the lofty mountain-tops; they hide themselves in rifts of the rock, or spring up amid ruins; wherever a plant can take root, Flora makes her appearance with her splendid gifts.

But ocean, too, has its radiated flowers-its asters and pinks - and far more wondrous than those of terra firma; for, being gifted with animal life, they can open and close at will. In our seas, the Sea Anemones or Actinix principally display all the glories of the rainbow on the submarine plains; but between the tropics, the gregarious reef-forming Corals cover the ocean bed with a gay carpet.

The glorious picture which the Astrex and Mæandrines unfold on the bed of the Red Sea, aroused in Ehrenberg the greatest admiration, so that he exclaimed enthusiastically: "Where is the flowery paradise, which, in variety and beauty, can rival these living wonders of the ocean?" 
Both the Sea Anemones and Corals belong to the widely ramifying class of true Polypes - animals of simple structure,

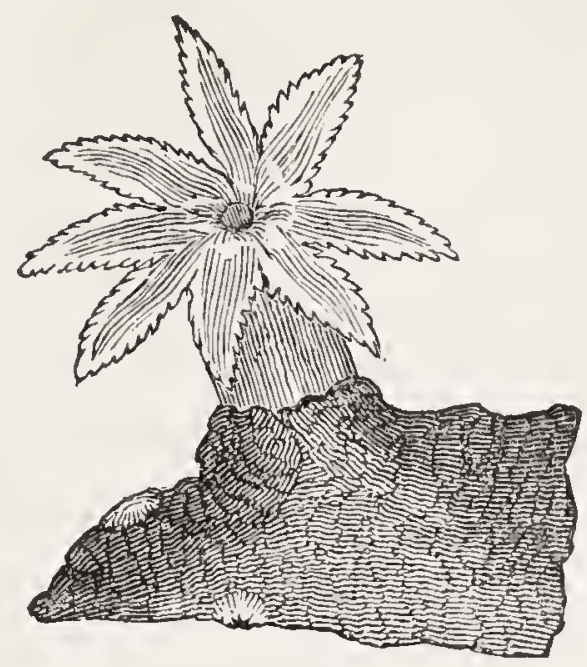

SEA ANEMONE.

which stand almost on the last stage of animalization. All varieties possess in common a sac-shaped body, surrounding a cylindrical cavity, which opens at top into a wide mouth. This

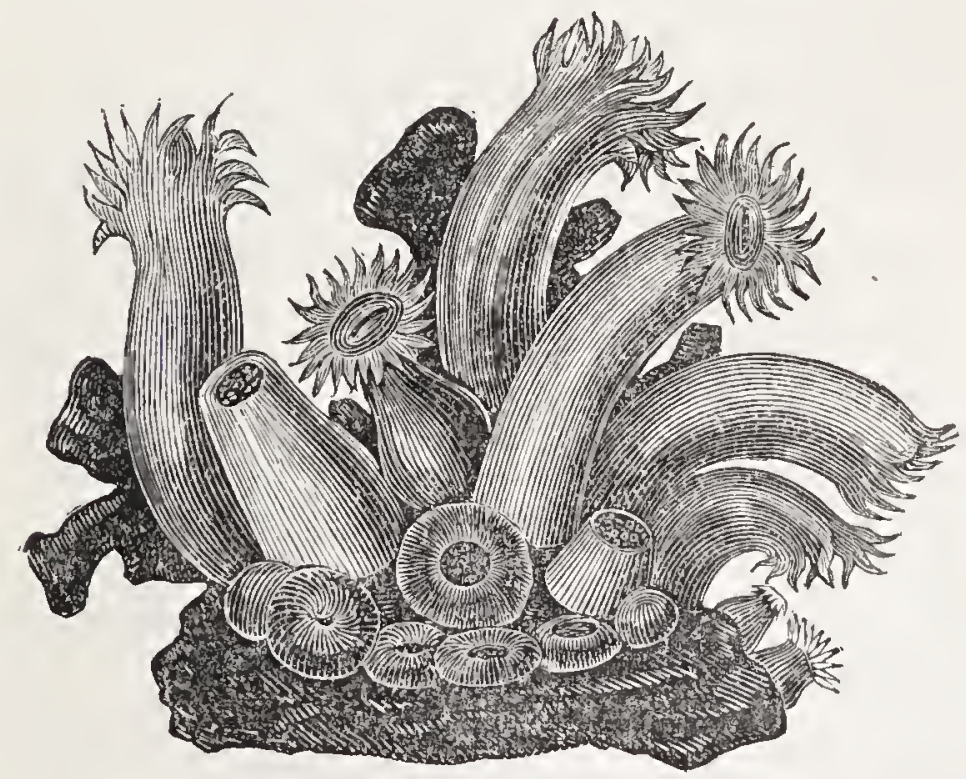

POLYPODON.

is surrounded by a fringe of tentacles, which extend and contract voluntarily, and carry food to the hungry predacious 
animal. Generally, firmly attached to their place of birth, or at the most, capable of only limited motion, the Polypes are unable to procure their food by fighting, personal strength, and cumning. Just as the helpless young of the higher animals are fed by their parents, they exist on what their kind mother, the ocean, conveys to them.

Their prehensile organs are traps, and not weapons; but, owing to the countless number of creatures with which the ocean swarms, especially on the coasts and in the shallow water where they have taken up their abode, the Polypes are never in want of famous food. No Lazzarone could wish a pleasanter mode of life than that of a Polype, for in it the dolce far niente is found in its most beautiful form.

In order that the capturing apparatus may serve its purpose perfectly, it is provided with countless small, needle-like weapons, which not merely wound the little animals that come within reach, but also poison them with an acid fluid. Woe to the small crustacean, or the tiny fish which comes too near the outspread, radiated crown of a Sea Anemone: surrounded in an instant by a hundred arms, it is suddenly stumned, and carried without further ceremony to the gaping abyss.

It is easily to be understood, that animals which require such a slight expenditure of intelligence, for existence, have no nerves, or, at any rate, in a most rudimentary state - a negative happiness, for which many a sensitive, hysterical person might possibly envy them.

They neither hear nor see: and, indeed, why should they? Owing to their impossible or defective locomotion, the possession of the higher faculties would be of no aid to them, to escape the attacks of their enemies, just as little as it was 
necessary to facilitate their capture of booty, which comes to them spontaneously, without their having occasion to see or hear. The sense of feeling, which is mainly concentrated in their prehensile apparatus, and at whose signal they cling round their prey convulsively, or hide themselves, with lightning speed on hostile contact, was evidently sufficient for all the demands of their limited existence; the more so, that it is extraordinarily sensitive of various irritating causes. The Sea Anemone feels the light: beneath a bright, clear sky, it unfolds all its beauty; but if a dark cloud obscure the brilliancy of the sun, the radiated crown is contracted, and the flower becomes a shapeless mass. But we should greatly err, if we thought it capable of feeling pain.

Only a few Polypes are simple and capable of movement, and among these are the Sea Anemones. Here we see a solitary flower, which springs from a simple stalk containing

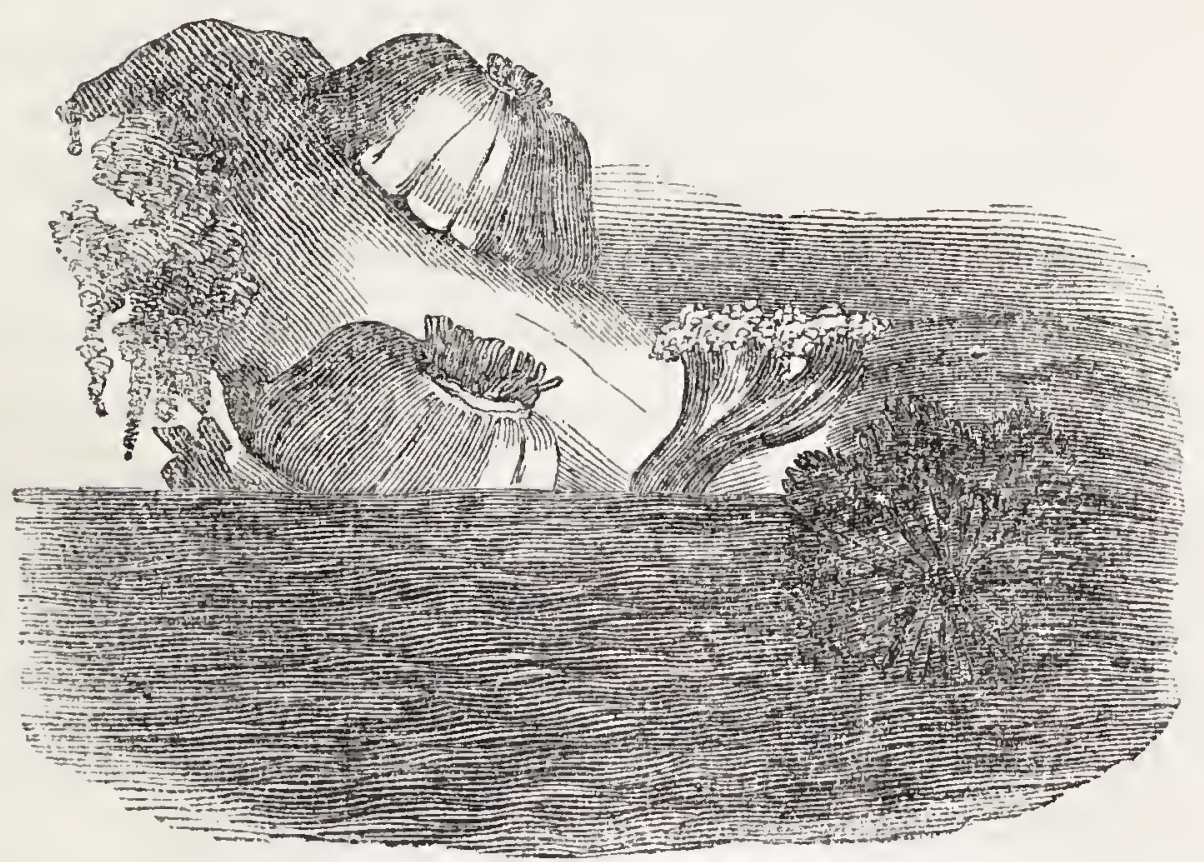

GROUP OF ACTINIAE. 
a stomach. With their broad base, the Anemones attach themselves so firmly to stones and rocks that they can only be separated from them with great difficulty, though, if they feel a fancy for moving, they can change their locality in various ways. They glide slowly and almost imperceptibly along the stalk; or, turning over, they use the tentacles as feet, or, blowing out the body with water, lessen its specific gravity, and allow themselves to be carried by the current, whither it may please.

Their tenacity of life is extraordinary; and for this quality, too, they may be envied by all those who do not at all like the idea of a separation from the pleasant habit of existing and working. Let them be dipped in water, hot enough to blister the hand - let them be frozen and thawed, or place them in the exhausted receiver of an air-pump - their powerful vital principle is victorious over all such trials. If the tentacles are cut off, they grow again; if once more removed, a fresh garland is produced. If the animal be cut in two, after a while the lower part of the body puts forth new arms, nearly as they were prior to the operation; while the upper portion continues to swallow food, just as if nothing had occurred. At first, like Munchausen's horse, it allows the food to fall out again through the open end; but it soon learns to retain and digest it. Johnson ("British Zoophytes") even mentions an instance, in which such an amputated upper body, instead of healing at the base, formed there a new mouth, with tentacles; so that, in this way, a truly gifted double-eater was produced, which could capture and devour food at both extremities.

But these otherwise indestructible animals die at once when 
dropped into fresh water-for them, as for many other marine creatures, as rapid a poison as Prussic acid to man.

Sea Anemones are found in every sea, and the German Ocean has also several splendid varieties; among others, the purple $A$. equina, which lives on rocks and reefs, and the white $A$. plumosa, whose disk, often measuring four inches in diameter, is covered with close, short, brilliantly white tentacles; but the largest and finest are found in the Tropical Ocean. Their colour is as various as the arrangement of their tentacles: there are some bright red and green, light blue and orange-coloured, yellow and milky white. At times, the tentacles form a Gorgon's head of long thick fibres, covered with the softest velvety lustre; in others, they represent a forest of thin threads.

This race is also compelled to pay tribute to the human palate. Thus, the Actinia fordaïca, a handsome variety, with scarlet tentacles, found in the Mediterranean, is considered a great delicacy in Italy, and thousands of them are eaten among the other frutti del mare.

The young of the Actinix, which are produced from small gelatinous eggs, remain at first in the maternal cavity, where they find a sufficiency of food, and are gradually converted, without any further remarkable changes, into the permanent form. At birth, or on emerging into the water, the only difference consists in the smaller number of tentacles, and the partition wall of the cavity.

The Lucernarix, distinguished by a remarkable gracefulness of form, are closely allied to the Actiniæ. The bellshaped body rises on a narrow stalk, which is usually found attached to smaller marine plants on a rocky soil. The ten- 
tacles are arranged, at regular intervals, in tufts round the edge. The crystalline animal reflects green or red tints, and can move with tolerable rapidity through the water, by alternate contraction and dilatation.

The Sea-pens, and other related varieties, such as the Virgulariæ, Veritellæ, etc., seem capable of change of locality -they are composite, coralline polypes-which are not firmly attached to the ground, but only have the stalk thrust into the loose sand. 'The Sea-pens possess the faculty of iridescence. If irritated at any place, the light flashes from one branch and one polype to the other, till it reaches the outermost point, while all the animals beneath the irritated spot remain in darkness. If the Polypodom be thrown into a vessel of sweet water, it emits sparks from every branch, which produce a magnificent sight.

These simple or gregarious families of Polypes, like all those found in our waters, are insignificant when compared with the reef-forming Corals of the hot zone. These are propagated partly by producing small, simple, globular or oval larvæ, capable of independent movement by the possession of an external coat, which swim about for a period free, till they attach themselves with one pole of their body, and lay the foundation of a future Polyp colony. Partly, too, they multiply themselves, like plants, by gemmation, and form in this way numerous societies, whose individual members are most closely connected. Each individual has its special mouth and tertacles, and its own stomach; but it has no other specialties; for it is connected with its brethren by interminable canals and webs, so that the juices each Polype evolves benefit the entire hive. This must, therefore, be regarded as 

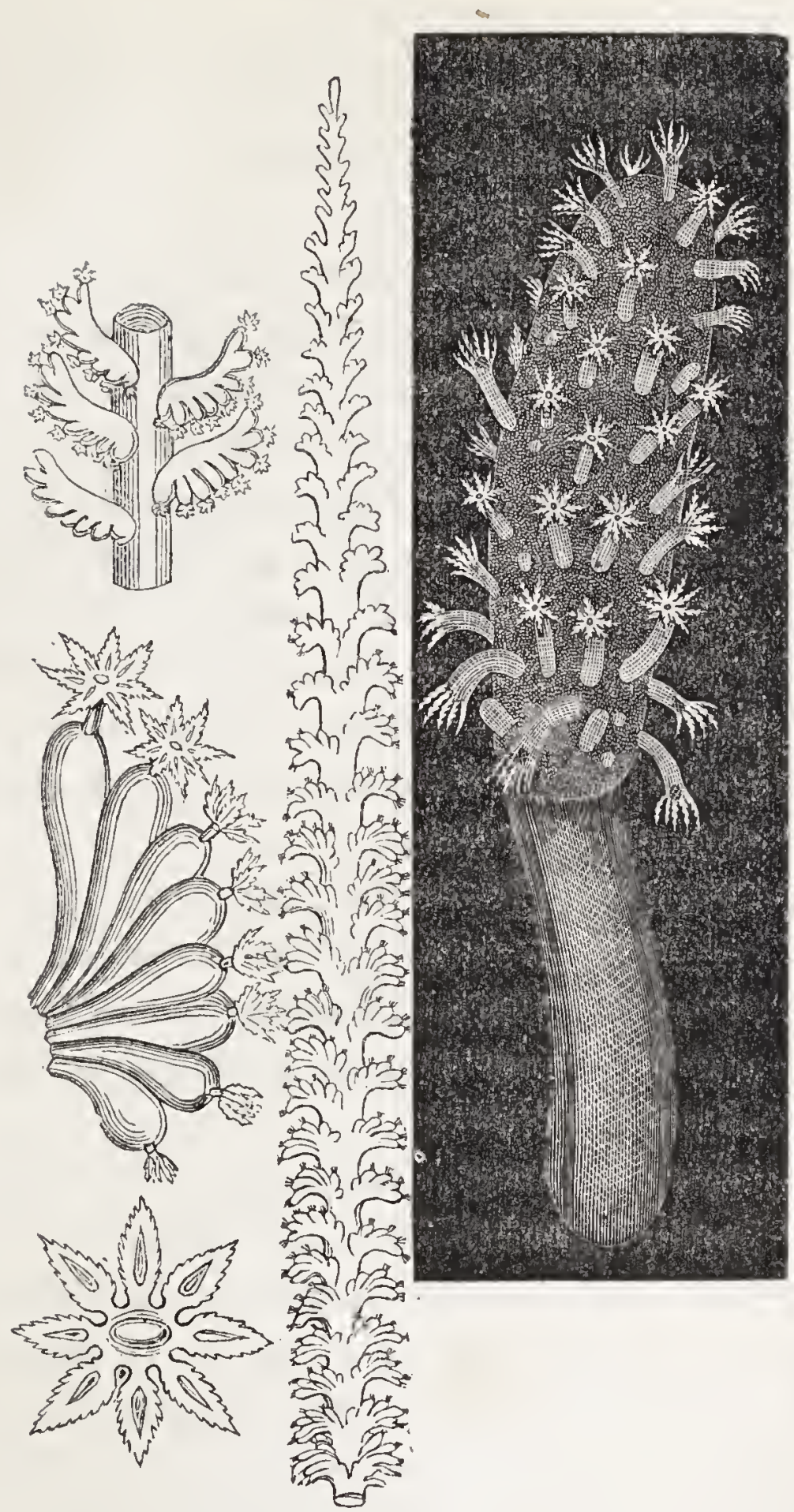

STRUCTUIRE OF FOLYPODOMS.

a living layer of animal matter, which is fed by numerous mouths, and supported by an equal number of stomachs. It 
deserves honourable mention, that the firm calcareous skeleton is always covered by the common skin of the colony, through whose numerous openings a rich flora of radiated flowers buds.

As the Lithophytes, or Stone Corals, have a growth

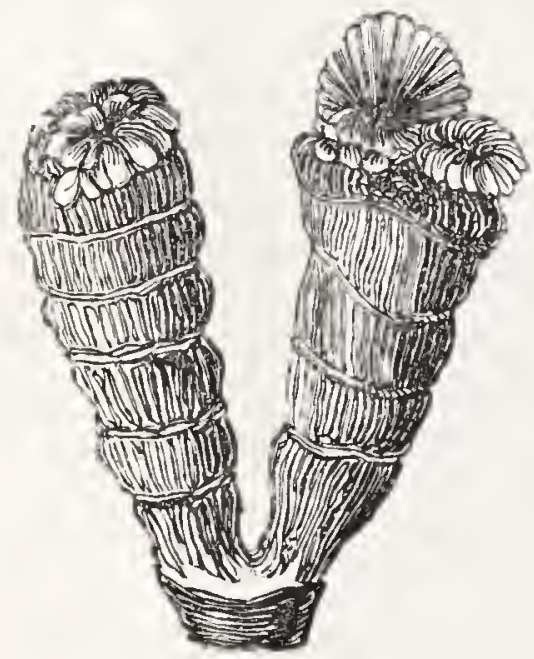

LITHOPHY TE. resembling that of plants, it must excite no surprise to find that they imitate all the forms of vegetation. We find among them mosses and creepers, shrubs and trees, which attain a height of six to eight feet; or graceful vases and symmetrical cupolas, which often have a diameter of ten and even twenty feet.

But all these variously-developed forms spring originally from a single spray, which, proceeding bud by bud, according to its peculiar nature, forms the broad leaf, the thin spray, or the hemisphere.

It may be said of the tropical Zoophytes, which form the wall-like Coral-reef, and in the truest sense of the term, that they build for eternity. The skeleton of the higher animals disappears from the earth in a few years; but the stone skeleton of the Polype remains firmly rooted to the spot which it occupied during life, and serves a new generation as the foundation on which it continues building. As a general rule, all the lower strata of the larger Polypodous aggregates are dead masses. Thus, the large hemispherical domes of the Astrex are covered with a living layer, which is only half an 
inch thick; and, in some of the Porites of equal dimensions, the entire mass is found to be lifeless, except a thin external crust of about one-sixth of an inch in thickness.

We are amazed at the size of the Pyramids and primeval temples, which a long-vanished race piled up on the shores of the Nile; but what are the colossal structures of the Pharaohs when compared with the mighty walls which are erected by the small weak zoophytes?

According to Darwin, to whom we owe the talented explan ation of the strange forms the Coral reefs offer, these animal edifices are naturally divided into three classes, while their physiological mode of structure always remains the same.

One description of reef is immediately connected with the continental or island shores (shore reefs, fringing reefs); to this variety belong all the Coral-banks of the Red Sea, which Ehrenberg and Hemprich investigated during eight months.

A second variety forms, at a greater distance from land, a wall, which either runs along the coasts (barrier reefs), or encloses a central island (encircling reef). Among these is the great Barrier Reef, which lies opposite the north-eastern coast of Australia. According to Flinders, it has a length of nearly a thousand miles, and runs parallel with the coast at a distance of twenty to thirty miles, which, in some parts, extends to fifty or seventy.

The huge arm of the sea, formed in this manner, has an average depth of ten to twenty fathoins, which at one end, however, increases to sixty, while the open sea beyond the reef is of unfathomable depth a very short distance off. The superficial width of the reef varies, in different parts, from some hundred feet to a mile. Probably this coralline wall, 
whose dimensions, it will be seen, laugh to scorn every human construction, is the most magnificent erection of the sort which the present epoch of creation has to offer us.

There is a large number of these island-girdling reefs, especially in the Pacific. Such, among others, is Tahiti, the Queen of Polynesia, with its girdle of palms and breadfruit trees. This paradisaical mountainous island rises in the midst of a calm sea, which the coral wall cuts off from the violent surf of the ocean.

The encircling reefs are found at a very great distance from the island they protect. Thus, the distance between New Caledonia and its coralline wall is no less than one hundred and forty miles.

The third variety of Coral-banks (Atolls, or Lagoon islands) differs from the former in the fact, that it does not enclose a verdant isle, but merely a central sea, or great expanse of water. Such Atolls are found close together in what is called the Coral Sea, between the northern coast of New Holland, New Caledonia, the Solomon's Islands, and the Louisiadian Archipelago; in the low archipelago, formed of eighty islands; at the Feejee, Ellice, and Gilbert Islands; in the Indian Ocean, to the north-east of Madagascar, under the name of the Atoll Group of Sayo de Malha; at the Marshall Islands (Radack and Ralick), to the east of the Ladrones; in the Maldive and Laccadive Archipelagos, and in many other parts of the Tropical Ocean.

Between the tropics, the constant action of the trade winds on the boundless surface of the sea, produces breakers far more terrible than those of our temperate zone, and of incessant fury. It is impossible to regard these hoarsely-growling 
waves without entertaining the conviction, that even the hardest rock must eventually yield to such a force. But the low coralline banks victoriously resist such attacks; for here a new living power enters the lists against blind physical force. The waves may tear from the Coral-reef thousands of blocks; but what does this signify against the piled-up labours of countless myriads of little architects, who are engaged day and night in extracting calcareous atoms from the foaming waves, and arranging them in systematical constructions. Thus we see the vital strength that exists in the soft gelatinous body of a Polype conquering the gigantic power of an ocean, which neither the works of human skill, nor those of inanimate nature, can withstand.

The reef-forming Corallines, which in this way defy the utmost efforts of the waves, are, in other respects, extremely delicate and sensitive. They require a warmish water for existence, and only inhabit those seas whose temperature never sinks below $60^{\circ}$.

The effect of the ocean-currents has, consequently, a great influence on their appearance. At the Gallipagos, which lie below the equator, but are exposed to the chilling influence of the Peruvian Stream, no Corals are found; while, favoured by the warm Gulph Stream, they are seen round the Bermudas, although those islands lie from four to five degrees beyond the usual boundaries of the Coral reef.

A clear, unpolluted saline water is also indispensably necessary for their existence. They shun slimy, sandy coasts; and opposite flowing rivers, there are corresponding holes in the reefs they throw up.

There are also many unexplained circumstances which, in 
some parts of the sea, favour the congregation of building Polypodoms, and in others compel their entire absence. Why, for instance, the north-western coast of Africa, St. Helena, Ascension, San Fernando, the Cape Verde Islands, where the temperature is most suitable, are entirely free from Corals, which are found so frequently on the eastern coasts of Zanzibar, and in the adjacent seas, no one can satisfactorily explain. As the sea is frequently fathomless at a short distance from the Coral reef - as off the Keeling islands, where Captain Fitzroy found no bottom, with a line of 7,200 feet, scarce a mile from land - it was formerly believed that the Lithophytes built up their precipitous walls from the depths of ocean; an opinion which is no longer tenable, since Quoy and Gaymard, Ehrenberg, Darwin, and other distinguished naturalists, have proved that the depth at which the reefforming Corallines can exist (Astreæ, Porites, Millepores, etc.), is, at the most, twenty to thirty fathoms.

Quoy and Gaymard, who accompanied the circumnavigator Freycinet, on board the Uranie frigate, have expressed an opinion that the Corallines merely formed a proportionally thin crust on the crest of submarine chasms of mountains, or the circular edges of volcanoes; and in this manner explained, not only the remarkable appearance of the Atolls, but also the precipitous descent beyond their rings. But this theory has not stood the test of a more careful investigation; for no known crater has ever attained such an expanse as, for instance, several Atolls in the Radack Archipelago, one of which is thirty-two miles long and twenty broad.

Besides, the numerous volcanoes, on whose edges the Atolls were afterwards formed, must have all approached the surface 
to the slight depth in which the reef-forming Coral varieties can alone exist: a supposition which is most improbable; for where on land can we find large and broad mountain chains, whose elevations attain such an altitude?

Further, the Corals do not grow higher than to the verge of the lowest water-mark at ebb tide, or, at the most, four to six inches above it; and though the waves may pile up loosened fragments to a height of thirty feet, still they could not form coral islands sixty feet in height, like Tongataboo, or, as at Eua, elevate the reef three hundred feet above the water-mark.

But this fact the Quoy and Gaymardian theory took as little into account, as it did the encircling reefs that surround the lofty mountainous islands.

Charles Darwin was the first to find the key to all these geological riddles, by deducing the formation of the varying Coral reefs from the oscillating condition of the bed of the sea, and its periodical elevations and depressions.

Just as it is now undoubtedly proved, that some portions of terra firma are continually rising (Scandinavia, Chili), while others are sinking (Dalmatia, Greenland), there are also rising and sinking regions in the Ocean. Among the latter, for instance, is that space, 4,000 miles long and 600 broad, on which the Society Islands and the Lower Archipelago culminate, the Coral Sea, the long chain of the Maldives, Laccadives and Chayos Atolls. If, then, we fix our attention on any one coral-reef island in these slowly sinking regions, we find that, while it sinks, the equally sinking coral reef is raised, or at any rate kept in equilibrium by the new perpendicular erections of the corallines, which try to reach the surface. 
But the Corals lying near the open sea find there better nourishment than those pointing to land; the former grow quickly, while the latter pine away, and thus, with time, a reef is formed surrounding the island at a considerable distance, between which and the coast the sea is frequently found so deep, that large ships can anchor comfortably in this basin, as in a harbour.

At length, a period arrives, when, by continued sinking, the central island entirely disappears beneath the waves, and the Atoll, or product of the Zoophytes, which labour against the sinking process, is alone left.

Hence, wherever low lagoon islands are now visible, once lofty lands rose from the sea, whose existence would be forgotten, did not the coral erections remain in evidence.

From the present size of the reefs it is calculated that the plateau which was lost in this way from the Pacific, covered at least 2,000 square miles; and, as there may have been lands whose sinking proceeded too rapidly for the corals to hold their own on the surface, this estimate is probably far beneath the reality.

The length of time needed for the formation of these colossal coral banks may be judged from the fact, that D'Urville found the anchors of Perouse's ships lost forty years previously off Vanikoro, at a depth of fifteen feet, covered with only a small crust of coral, and that the anchor which Anson, the circumnavigator, left off the island of Tinian, in a depth of twenty-two fathoms, when found eighty-five years áfter, was also merely covered with a thin layer of coral. Thus the naturalist is shown the extreme age of our planet by the reefs of the tropical ocean. 
While some portions of the bad of the sea are sinking, others again are rising. These masses of raised coral prove, that the New Hebrides, Solomon's Islands, New Ireland, the Friendly Islands, \&c., are emerging from the bed of ocean.

Round Eua Island runs a coral wall twenty feet high, in which the surf has excavated deep cavities and spouting holes. At such places the in-rolling wave produces intermittent springs, which start from the perforated rock with inmense force.

Most interesting is the manner in which lagoon islands and encircling reefs eventually become the residence of man; for the Corals only build up to low water mark, and, therefore, every tide necessarily lays their labours under water. But where the living architects falter, the destroying surf displays itself as a creative might. It tears fragmenis and blocks from the exterior of the reef, and hurls them a long distance over its surface. Corals, shells, and sea-urchin houses are converted, by its crushing, grinding power, into lime, which gradually fills up the interstices of the large, irregularly-piled blocks, and imparts to them greater solidity. In this manner, the firm ground rises higher and higher, till at last only the spring tides submerge it. Soon, too, the tropical sun does its part in the further construction, by bursting and exfoliating the mass rendered torrid by its beams at various places. It is then rolled higher and higher by the fierce tides; and thus a wall is at length formed which even the stormy sea cannot overstep, and behind which the fine coral lime can collect undisturbed. Here the floating seeds and fruit, which the ocean currents often bring with them from distant latitudes, find a suitable soil, and begin to cover the glistening lime with 
light verdure. Trunks of trees, washed from their homeforests by floods, also drift on the shores of the newly-formed islands, and bear to it small animals - insects or lizards - as its first inhabitants. Before long, palm-groves beautify the new creation, an army of marine birds has collected on the new place of refuge; and land-birds, which have lost their way, revel in the shelter of the bushes which grow there. Lastly, after vegetation has completed its task, man makes his ap-

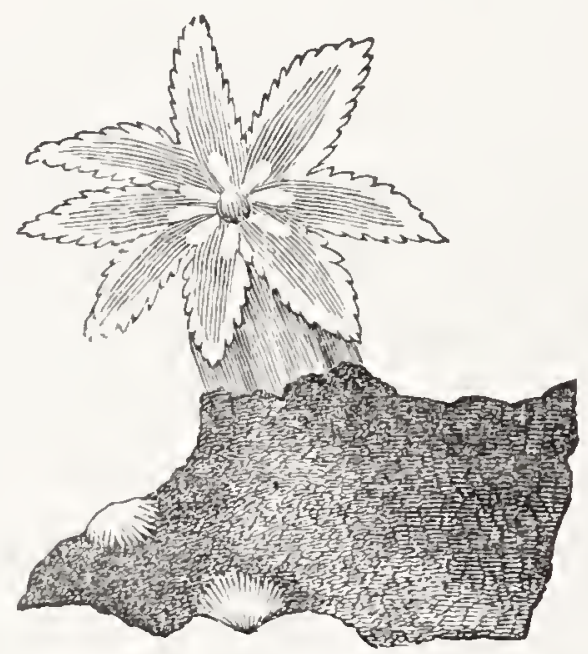

ISIS NOBILIS.

pearance on the scene, builds his hut on the fertile soil, which fallen leaves and rolling weeds have gradually formed, and calls himself lord of this small world.

Thus, in the course of ages, have been formed all the islands, connected in a link or arranged in circles, which rise upon the coral reefs of the tropical ocean; thus was formed the large territory of the Maldives, whose sultan, Ibrahim, bears the haughty title of King of the thirteen Atolls, and the Twelve thousand Islands. May his shadow never grow less, or his star set!

With a few words on the valuable Coral (Isis nobilis), we 
will close a chapter which has, perhaps, already grown too long. It is found in the Mediterranean, principally on the coast of Provence, from Cape de la Couronne to St. Tropez, off the islands of Majorca and Minorca, at Stromboli, and on the coasts of Sicily and Algiers. It grows in large banks on the rocky ground. Only the internal parts of the Polypodoms consist of the marbled red stony substance, which a large colony of Zoophytes cover with a softer living crust.

At Stromboli, and in the Straits of Messina, according to De Quatrefages, the coral fishery is carried on now just as Marsigli described it 150 years ago.

A large wooden cross, weighted with stones, whose arms of equal length carry nets made of tow, is lowered on to the rocks for a depth of 200 to 300 feet. While one of the fishermen alternately raises and lowers this apparatus, his comrades row on slowly, so that a considerable distance is swept by it. Then the whole affair is drawn up, and the torn off pieces of coral which are found hanging in the meshes of the net, are taken out. Each boat has a crew of seven or eight men, and the fishery lasts from April to June.

The quantity obtained in these parts, annually, amounts to about 12 Sicilian quintals, each of 250 lbs. Formerly, the price of the raw material was $4 s .6 d$. the pound. Each bank is only dragged once in ten years, as the corals require that time to grow to perfection again. In Naples, many people live by polishing, perforating, and selling this beautiful marine production. 


\section{CHAPTER XII.}

The minutes't Life.-Foraminifera.-Amada: their wondrodsiy simple Construction.-Dlatomacede-Dinfusoria: their importance in the Oceanic Housenold.

$D^{\mathrm{O}}$ not think, dear reader, that with the enormous families of fish, molluscs, jelly fish, crustaceans, and polypes which we have brought to your notice, that Life in the Sea is exhausted, and that the salt water, or the sand on the shore, contains no further marvels for you. To the unassisted eye all this may certainly appear desolate and uninhabited; but the microscope, or even the magnifying glass, will soon teach you better, and, in the shortest space, reveal to you a new and astounding world. While walking along the beach, pick up a handful of the drift-sand, which the wind has collected, and examine it through a magnifying glass: you will perceive nearly always, under the coarse grains of the inorganic silicious earth, a quantity of the most graceful forms of shell: some shaped like antique amphoræ, others convoluted like nautili or ammonites - all in their smallness so carefully carved, and formed in such a masterly way, that no human artist would be able to produce them in the same perfection on an increased size.

The knowledge of these pretty creatures, of these Rhizo- 
pods and Foraminifera, as they are called, may justly be regarded as an achievement of the most recent times; for it is not much more than a century since they were first discovered by the Italian naturalist, Beccaria, in the sea-sand at Ravenna. For a long period, they were regarded as the exclusive product of the Adriatic: afterwards, they were found here and there in England and France: their universal propagation and importance in the Oceanic Household was only proved in 1825, by Alcide D’Orbigny.

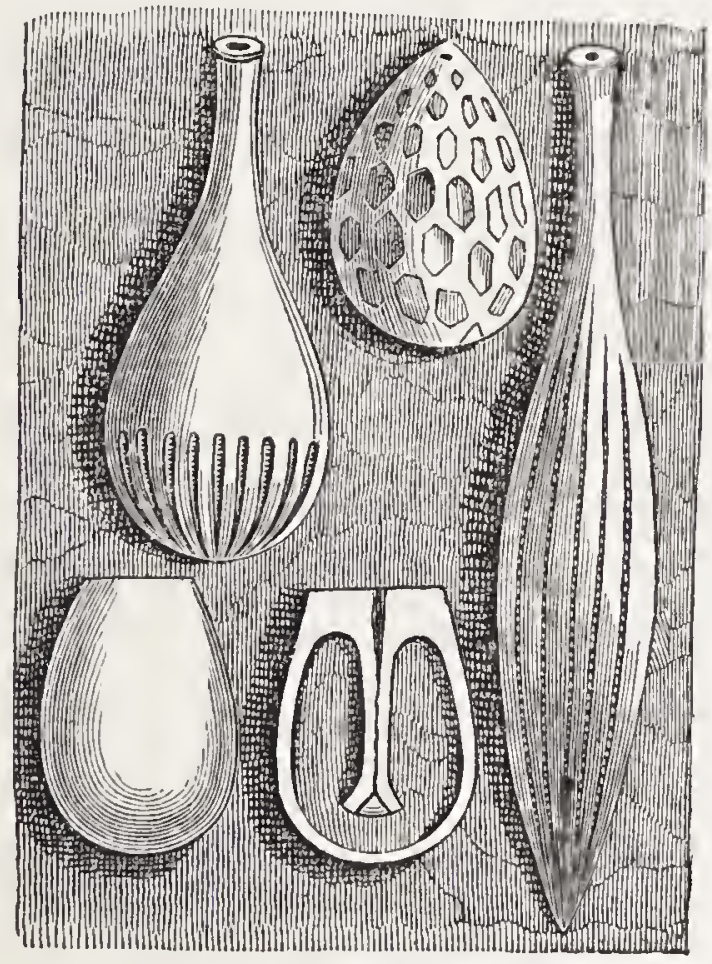

LA GEN 2 .

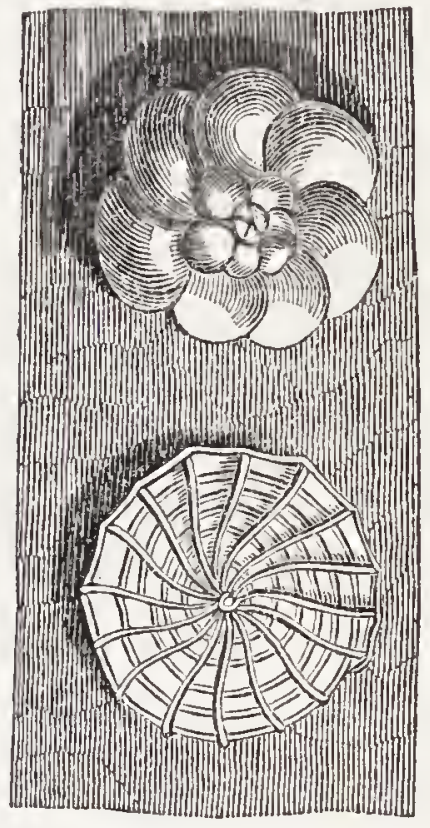

ROTALIA.

It has been conclusively shown, that Foraminifera are present in the sand of all sea-coasts, and in such extraordinary quantities, that they form a material portion of its weight. Jonas Plancus, who first drew them in 1739 , counted 8,000 in six ounces; D'Orbigny, in a pound of sea-sand, from the West Indies, 3,849,000. Schultze, by a fine sieve, separated 
all the coarse grains from the sand of Molo di Gaeta, which is remarkably rich in the smaller Foraminiferous shells; about one-half of the residuum consisted of well-preserved Rhizopod shells. When we learn further, that the sea-lead along the whole Atlantic coast of the States, continually brought up masses of Foraminiferous shells, from depths reaching to 90 fathoms: that, therefore, along this great distance - which is, however, but a small part of the enormous territory occupied by them-they plaster the entire bed of ocean-it will be seen no animal group can, in the slightest degree, cope with them in numbers; not even the fossil infusoria, of whicl 41,000 are found in every cubic inch of the stratum of Biline polishing slate, which occupies several square miles - for they have merely a local distribution - while the Foraminifera inhabit all waters.

The similarity of their shells to those of the Nautili and Ammonites, led at first to the belief that these gracefully spiralled calcareous shells were formed by similar animals, and their smallness was ascribed to the exhaustion of a form, which no longer found the conditions of its earlier growth, in the altered state of the temperature and the components of the sea. Closer examination has, however, proved that they are animals of a very low order, which stand in close relation to the Amæba, also found in every sea. Other animals amaze us by their composite structure, the multiplicity of their organs, while each, designed for a special purpose, forms a harmonious whole; but, in the Amæba, the extremely simple structure of the body arouses our highest admiration. Nowhere do the mysteries of vital strength appear to us in a more wondrous light than in this case, where it reveals its 
most secret arrangements withouit any appointed instruments. The Amæba is nothing but an animated being, of a loose, pellucid, colourless, contractile substance, whose individual life is revealed by various changes of form, which bear the character of arbitrary motion. The larger mass of the body floats after a rounded or pointed, longer or shorter, continuation, which can grow from any part of the body: similar continuations grow afresh, and produce, by the constant change of motion, protran alterations of form in this simplest of all animal bodies. There is no distinction between cuticle and body in them; and the movements of these beings appear acts of volition; but there are no special organs of motion and feeling in their simple forms. They cannot exist in a body, whose parts are so thoroughly equivalent, that each grain can at any moment change place with another.

The substance seems not only regularly contractile, but also equally irritable at every part of the body, and adapted to receive food and digest it. If an Amæba draws near another small animal or vegetable organism, whose movements are not sufficiently quick to escape the enemy, it spreads its many-shaped continuations round it; after surrounding the strange body, they float behind it together, and the prisoner lies enclosed in an animal substance, till all that is soluble is extracted from it.

Though the Foraminifera and Amæba have no difference of internal form, externally they differ greatly. The principal distinction is, that, in the latter, the body is naked; but, in the former, exhibits a husk on its surface, through which the soft animalcule inside thrusts forward the fleshy parts that are used for crawling or seizing prey, by means of one or 
more openings. The outstretched threads seem to have something poisonous in their nature; for Dr. Schultze, of Griefswald, who has written a most interesting Monogram on the Foraminifera, repeatedly noticed that small lively Para. mecia, Colpodes, and other Infusoria, were entirely deprived of their motive powers by any sudden contact with the out. stretched net of threads.

The calcareous structures of the Foraminifera, of which 1,600 varieties are already known, are remarkable both for their prettiness and the multiplicity of their forms. They are found globular and bottle-shaped, straight and spiral; some have only one large opening, others have countless small holes all round. In some, again, the cavity is simple, in others, divided into several chambers.

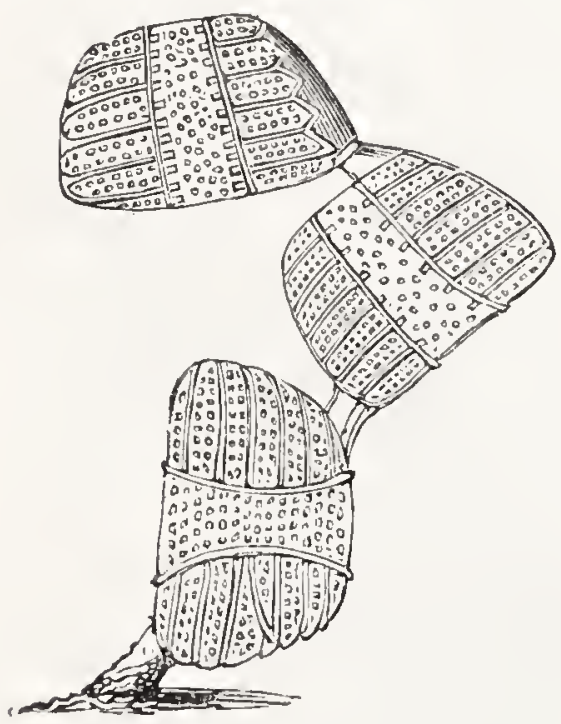

ISTHMIA.

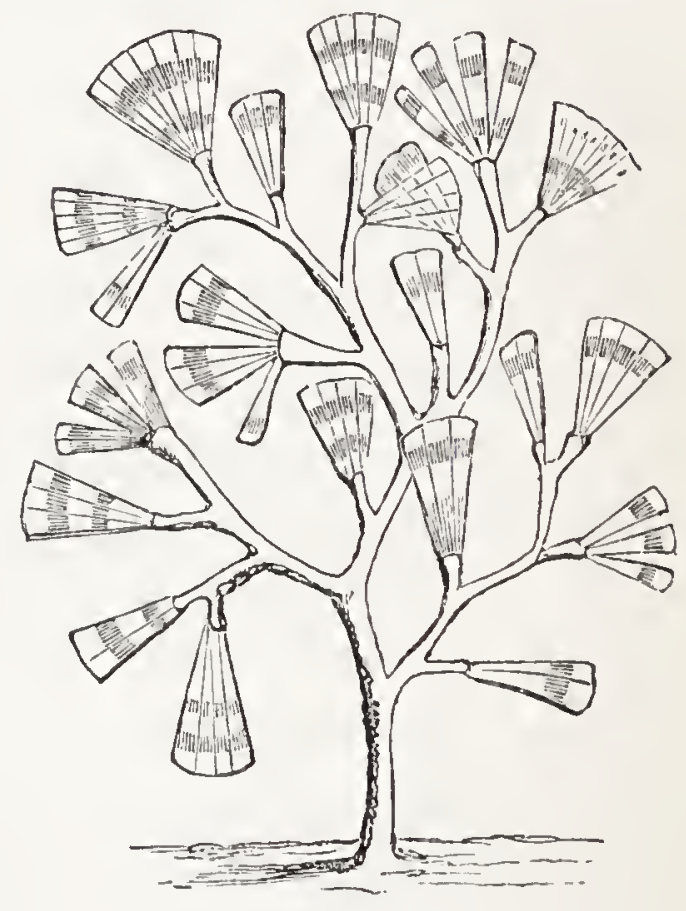

LICMOPHORA.

The Diatomaceæ play an equally great, if not greater, part with the Foraminifera in the ocean kingdom. The forms of 
these strange microscopic creatures display to us regular mathematical figures - cubes, triangles, parallelograms such as are found in no other plants; and their surface is frequently most elegantly carved. They are found in every sea. On Sir James Ross' last voyage of discovery to the South Pole, the lead was sunk in depths which would have held Chimborazo, and Diatomaceæ were regularly brought up. The mighty ice wall which at length checked the southern course of the daring seafarers, was coloured brown by the Diatomaceæ. Floating ice, when melted, displayed them by millions. They often formed a dirty foam on the surface of the Polar Sea. The Diatomacex are covered with indestructible silicious husks, which explain the great geological value of both these microscopical creatures. Man, and all the mammals, disappear without a trace; in a short time their constituents are dissolved; while the Foraminifera and Diatomaceæ construct for eternity. Incessantly they lay their ever-increasing pavement on the ocean-bed: they are ever active in throwing up submarine mountains and banks, and filling bays and arms of the sea. At the first glance, it may appear an exaggeration to ascribe such an important part to beings which are so small, that millions are often needed to occupy the space of a cubic inch; but when we reflect in what astounding numbers they are found, how rapidly they multiply themselves by separation, and that, from the first dawn of animated nature to the present moment, their rapidlydying generations have followed each other, we can easily understand that they are among the greatest builders of the earth; so that the entire bed of ocean is nothing but a cataomb of Foraminifera and Diatomacex. 
In addition, the sea is peopled by a countless number of Infusoria, which move by the assistance of floating cilia, and whose complicated organism often astounds us. This whole

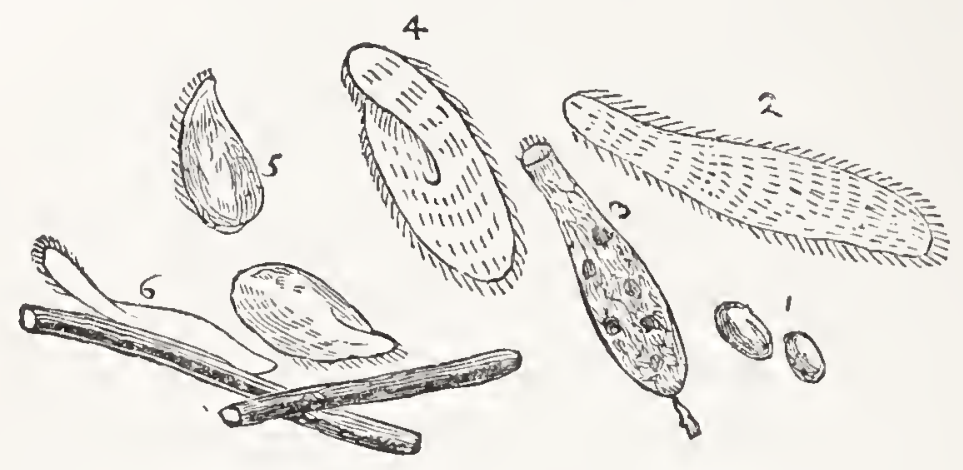

INFUSORIA.

microscopic world serves as nourishment to rather larger animals, which are again swallowed by more powerful creatures; till, finally, the larger fish, the sea-birds, the mammalia, and man, feed on the abundance of ocean. Their disappearance would, in all probability, depopulate the ocean. 


\section{CHAP'TER XIII.}

Marine Plants.-Zogtera marina.-Ulum and Enteromorpir ж.Varieties of Fucus. - Kelp Varech. - Laminaria.- Macrocystis Pyrifera. - The Submarine Forests at Tierra del Fuego.-Nereo-crstis Lithiana.-The Sargasso Sea.-Irish Moss.-Jin Jan, or Agar-Agar.-Sponges: their remarkable Growth.

WHHE terra firma develops its richest plants on the lowest spots - in plains and in bottoms - and the size and variety of its growth decreases in the loftier mountainous regions, till at last all vegetation dies out, we find quite a different arrangement in the Ocean empire. Here the greatest depths are plantless, and the calcareous nullipores, mosses, and lichens, are not found below a depth of from six to eight hundred feet. Gradually, corallines and other varieties of sea-weed join them, till the rich girdle of plants which the sea displays on its frontiers, commences about 100 feet below the surface of the water. The plants which form it stand, it is true, at a lower stage of development than those of the land, and lack the splendour of the flowers and fruits; but, just as the earth ever appears in a new garb at different heights and latitudes, and attracts our highest admiration by the unending multiplicity of its ornaments, so the forms of the Algæ change, 
both in descending from the highest bed to the depths, and in moving along the coast; and the leaves of these marine plants are deficient neither in beauty of colour, nor in gracefulness of form.

The different media in which land and marine plants live, necessarily demand equally different modes of support. The former principally employ their roots to draw nourishing essences from the lap of earth : the Algæ, on the other hand, imbibe along their entire surface the materials needed for their support, and the roots are only employed for adhesion. The peculiar constituents of the soil are very important to the land plant, for it lives partly on them: with the marine plant, it is a matter of indifference whether the ground on which it grows is composed of granite, chalk, slate or sandstone, if it only afford safe anchorage.

Flat rocks, which are not too greatly exposed to the pressure of the waves, and have numerous excavations that remain full of water at ebb-tide, are hence the favourite residence of the majority of marine plants, while the shores consisting of loose sand are equally as barren as the Arabian desert. But even on sandy coasts, large submarine meadows are sometimes found. The Zostera marina (Grasswrack), the only phanerogamic or flower-bearing plant of the German ocean, is admirably adapted to attach itself to loose sand, through its trailing stalk, from whose knots or joints long roots grow out. The long grassy leaves, of a bright green and silky lustre, which move freely in the water, afford food and protection to countless animalcules and plants. In the tropical sea, the sea-grass is eaten by the turtles; and, in the north of Europe, it is used for making cheap mattrasses. 
Large quantities are exported to England from Ostend for this purpose.

The Algæ are divided into three large groups - the green (Chlorospermece), the olive-coloured (Melanospermec), and the red (Rhodospermece), which are subdivided again into a number of families, genera, and species. On the British coast alone, there, are some 370 species, belonging to 105 different genera; so that an idea may be formed from this of the richness of the Ocean botany. Thousands are already known; but of a surety as many again are waiting for their botanic name, and have never yet been gazed on by a human eye.

The Chlorosperms, or green sea-weeds, are found most frequently near high-water mark, and love to lead an amphibious life, half in the air, half under water. To them belong the silky Enteromorphæ and ribbony Ulvæ, which, at suitable spots, cover the coast rocks with the most vivid green. Very remarkable, too, is the wide geographical extension of these genera. The Ulva latissima (sea-lettuce), and Finteromorpha compressa (sea-grass) of our coast, grow on the desolate shores of the Arctic Ocean, skirt the tropical Ocean, and extend southward to Cape Horn. But few plants and animals possess such a flexible nature, as to accommodate itself to the most varying climates.

The group of the olive-coloured sea-weed plays, however, a far more important part in the Ocean household. To it belong both the species which, on the fall of the tide, give our rocky shores their peculiar, gloomy colour, and the mighty Laminariæ (oar-weed), which, wherever they find a firm soil, form a submarine forest-belt round the coasts to a depth of several fathoms. 
The small Tiucus canaliculatus, whose small channelled stems and branches have no air-vessels, first makes its appearance on our leaving the land; it is followed by the Fucus nodosus, a large species, with powerful-looking stalks distending at some places into air-vessels; and by the Fucus Vesiculosus, a gregarious plant, which covers the rocks far and wide, from one to two feet above high water mark down to the verge of the lowest tide. Through the broad forked leaves runs a wide rib, which is ornamented on each side with numerous air-vessels found in pairs. The deepest spot in the littoral zone, or belt of rock, extending between ebb and flood, is occupied by the equally gregarious Fucus Serratus, which is distinguished by its toothed margin leaves and absence of air-vessels.

These species of Fucus are very frequently found on the flat rocky west coast of Scotland and Ireland, as well as in Brittany, where enormous quantities were formerly burnt, and sold for the production of soda under the name of kelp or varech. At the Orkneys alone 20,000 men were engaged the entire summer in collecting and burning it. Now it is no longer employed for this purpose; as, to the great injury of the needy inhabitants of those coasts, soda is obtained more cheaply from salt; still they are employed in collecting iodine, which, of course, has not nearly such commercial value. It is also greatly used for manuring fields, some being reduced to ashes, some in a mouldering state. 'Thus several ships annually visit the coast of Brittany from Jersey, to fetch cargoes of sea-weed for that island.

The largest sea-weeds of the German Ocean are the Laminaria saccharina, and digitata. 'The former is found in 
broad, leathery, waving ribbons, two to three fathoms in length; the latter in long tufts growing on stalks, three to four feet in height. These large plants are, however, but dwarfs, when compared with the gigantic Laminaria of colder regions. Only one of the plants belonging to this family is found in tropical waters; but, on the other hand, it extends to the furthest aretic limits, and increases in size and variety toward the poles. The northern hemisphere has more genera than the southern. Both in the North Atlantic and Pacific are found the Gigantic Alarix, with leaves forty feet long, and several feet in width; and in the extreme north the Agarum Thalasso-phyllum, Costaria, and Nereocystis; the latter only found in the Pacific, while Macrocystis and Isessonia flourish mostly in the southern hemisphere.

In the numerous channels and bays of the Tierra del Fuego, the extraordinary growth of the Macrocystis Pyrifera excites the admiration of all visitors. On every rock, Darwin says, from low water mark to a great depth, both along the outer coasts and in the channels, this gigantic marine plant grows. It is astonishing how it can flourish beneath the mighty waves of the Western ocean, which no rock, however hard, can resist. 'The stem is round, slimy, smooth, and rarely more than an inch in diameter. Captain Cook tells us, in his second voyage, that at Kerguelen's land this plant attains an enormous length, although the stem is not above the thickness of a man's hand. On some of the rocks where it grows, the bottom was not found with a twenty-four fathom line. As the Macrocystis does not grow perpendicularly, but forms a very acute angle with the ground, Mr. Darwin considers himself justified in giving it a length of 400 feet and more. 
The number of living things of every sort, whose existence is closely connected with that of this huge bladder wrack, is astounding. Nearly every leaf, with the exception of those floating on the surface, is so densely covered with corallines, that they impart to it a white colour. To the flat surface of the leaves, various Mussels, Tops, Molluscs, and Bivalves attach themselves. Countless Crustaceans live on some parts of the plants. On shaking the large tangled roots, a pile of little fish, shelled Molluscs, Cephalopods, Crabs, Sea Urchins, Asteroids, handsome Holothuriæ, Planariæ, and crawling marine animals of every possible shape is found.

Under the leaves of this plant, Mr. Darwin also tells us, numerous species of fish live, which would find food and shelter no where else; if it perished, the numerous Divers, Gulls and other fishing birds, and the Otters, Seals, and Porpoises would also be destroyed; and, lastly, the savage, the wretched lord of that unlucky country, would be compelled by hunger to double his cannibal repasts, and, probably, in his turn, disappear from the globe.

When three days from Cape Horn, large masses of sea weed, torn off by the storms, announce to the navigator that lie is approaching the Fire-land. "We succeeded," Meyen says, "in securing one of these floating islands, which was drawn on to the deck by the exertion of five men. It was impossible to disentangle this enormous mass, and we could only trace the apparent stem for sixty-six feet. The branches were thirty to forty feet long, and as thick as the parent stem, from which they depended. We estimated the entire length of the plant at 200 feet; the pear-shaped air vessels at the base of the leaves were frequently six to seven inches long, 
and some of the leaves measured seven and eight feet. On these floating sea-weed islands were a large number of the most varying animal creatures, thousands and thousands of Lepadæ and Sertulariæ, Crustaceans and Annelids.

"The gigantic plants, which the mighty ocean shelters in the vicinity of Tierra del Fuego, attracted us as much as the luxuriance of the vegetation in the forests of Brazil. A single plant of the Macrocystis pyrifera, with its enormous mass of leafy substance, covered as large a space of land as those giants in the virgin forests of Brazil. The number of lower Algæ, Sertulariæ, Cellariæ, and all the other animals, that have taken up their abode on the floating islands, exceeds in variety the parasitical covering of the trees in the tropical forests. It seems as if in these desolate regions of the Earth, where the calmness of nature is only disturbed by terrible storms, the producing power of the planet is solely displayed in the giant growth of the submarine vegetable world."

Extraordinary masses of gigantic sea-weed, Macrocystæ, Lessoniæ, and D'Urvillex, are also met with on the rocky coasts of the Falkland Islands. Torn from the rocks and hurled on the coast, they collect in the surf into immense vegetable cables, much thicker than the human body, and several hundred feet long. Many of the finest and rarest Algæ may be discovered here, reminding the botanician by the similitude of form, of his distant home, while their sight tells him at the same time that he is in another hemisphere. The giant species of the Lessoniæ are principally met with near islands. Their growth resembles that of a tree. The trunk attains a height of eight or ten feet, and the thickness of a man's thigh, and terminates in a crown, whose leaves descend 
like the branches of a Weeping. Willow. Submarine forests are formed by this plant, which, like the Macrocystis, shelters an infinity of marine animals.

Equally rich in gigantic marine plants are the northern part of the Pacific, near the Kuriles, the Aleutian islands, and the island-studded north western coast of America, The Nereocystis Lutkeana forms dense forests in Norfolk Bay, and at New Archangel, in Russian America. The stem of the plant, which is often 300 fathoms in length, is not thicker than a ribbon, and terminates in a large stalk bearing a coronal of Dichotomous leaves, which reach a length of thirty and forty feet. Martius tells that that the Sea Otter, when watching for its prey, likes to rest on the air-vessels of these giants; and that the tough long stems supply the rude fishermen of those parts with excellent lines.

The growth of the Nereocystis must be extraordinarily rapid; for it is an annual, is never seen in spring, and therefore develops its enormous size in the course of a single summer.

Before we pass to the third great group of marine plants, the Rhodosperms or Fucoids, we must refer to the enormous weed meadows or fucus banks of the Atlantic, which are among the greatest marvels of the ocean. It is well known that the mighty Gulf stream, which pours its blue masses of water from America to Europe, at the Azores partly turns southward again towards the African coast, and is driven back to the American coast by the north east trade-wind. Within this limit a sea is enclosed from $22^{\circ}$ to $36^{\circ}$ N.L., and from $25^{\circ}$ to $65^{\circ}$ W.L., which displays very few currents, and those depending on the wind blowing at the time. This quiet 
portion of the ocean, whose surface is thrice as large as Europe, is found to be covered with larger or smaller heaps of Sargassum bacciferum. Some days it collects round the ship in such masses, that its progress is inpeded, while at other times hours elapse before a plant is seen. When Columbus crossed this unknown Sargasso sea, his desponding comrades became still more apprehensive; for they believed that these floating beds of sea-weed, which hemmed the course of their vessel, indicated the limits of the navigable ocean.

It deserves mentioning as an interesting, fact that these fucus banks afford us the most remarkable instance of gregarious plants of a single species. No where else, neither on the grassy prairies of America, nor in the heaths and forests of Northern Europe and Asia, is such uniformity of vegetation to be found, as in these mighty sea-weed beds.

"The collection of this enormous carpet of plants," Meyen says, " over a space of more than 40,000 square miles, has been, since Columbus's time, the object of admiration and investigation. Some navigators believe that this sea-weed is collected by the Gulf stream, and that in the Gulf of Mexico enormous quantities grow, a supposition, however, which does not now need to be contradicted, as I shall presently shew. Humboldt was of opinion, that these marine plants grow in shallow water, and are torn up by fish or molluses; perhaps, too by currents, and other causes. Von Martius believes that the weeds grow in shallow water at $24^{\circ}$ N.L., and $28^{\circ}$ W.L., and are torn off there by the Whales. It is inexplicable to me, how such enormous masses of this plant could be torn up from isolated shallows. I have examined thousands and thousands of these roots, and I may venture to assert, that they 
were never sessile. While swimming in the water, they have pushed out roots and leaves in every direction. I have noticed a similar development and growth among free Algæ spores, and the formation of a root among the floating Confervi, and hence I do not consider the growth of the sea weed, which floats about in the open sea, as so very wonderful. According to my opinion, they have been floating about at the place where they are found for thousands of years; but their mass must increase annually, though it is difficult to explain how. I must mention here the great number of animals which find their residence and food in these floating islands of Gulf weed. The Sargasso sea is usually covered with tiny Sertulariniæ, coloured Vorticellæ, and other strange creatures. Various Pleurobranchs and Nereids sit on the branches of this weed, and serve as food for the countless fishes and crustaceans, which have taken up their abode here."

Similar evidences are found in the Indian and Pacific Oceans at proportionally quiet spots, which are surrounded by rotatory currents. That their appearance is such a rarity, may serve as a proof of the restless motion of the waters. If this eternal circulation did not take place, probably the sea would everywhere be covered with weeds, which would be alone sufficient to impede navigation .

The Red Sea weeds, the Rhodosperms or Floridex, with a short account of which we shall conclude this chapter, embrace the greatest number of species, and, though not the largest, are the handsomest in form and colour. 'They like neither light nor motion, and hence remain beneath the shadow and protection of the larger varieties, on the shelving sides of deep hollows. Many of them grow at a depth below 
the tidal influence, but the majority are found on the line of low water mark, and are only visible for a few hours during

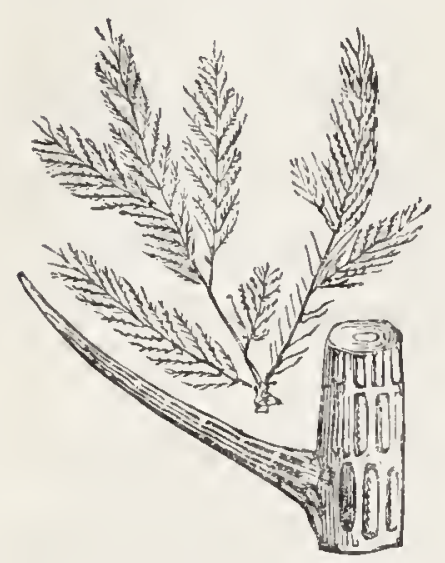
the spring tides, when the sea runs out to the fullest extent. To this group belong the wondrously delicate Polysiphoniæ, Calithamniæ, Delessertiæ, Plocamiæ, etc., which delight the collector's heart by their gracefulness, and bright pink, scarlet, or purple colouring, as well as the calcareous polysiphonia Parasitica. Corallines and Nullipores, in which

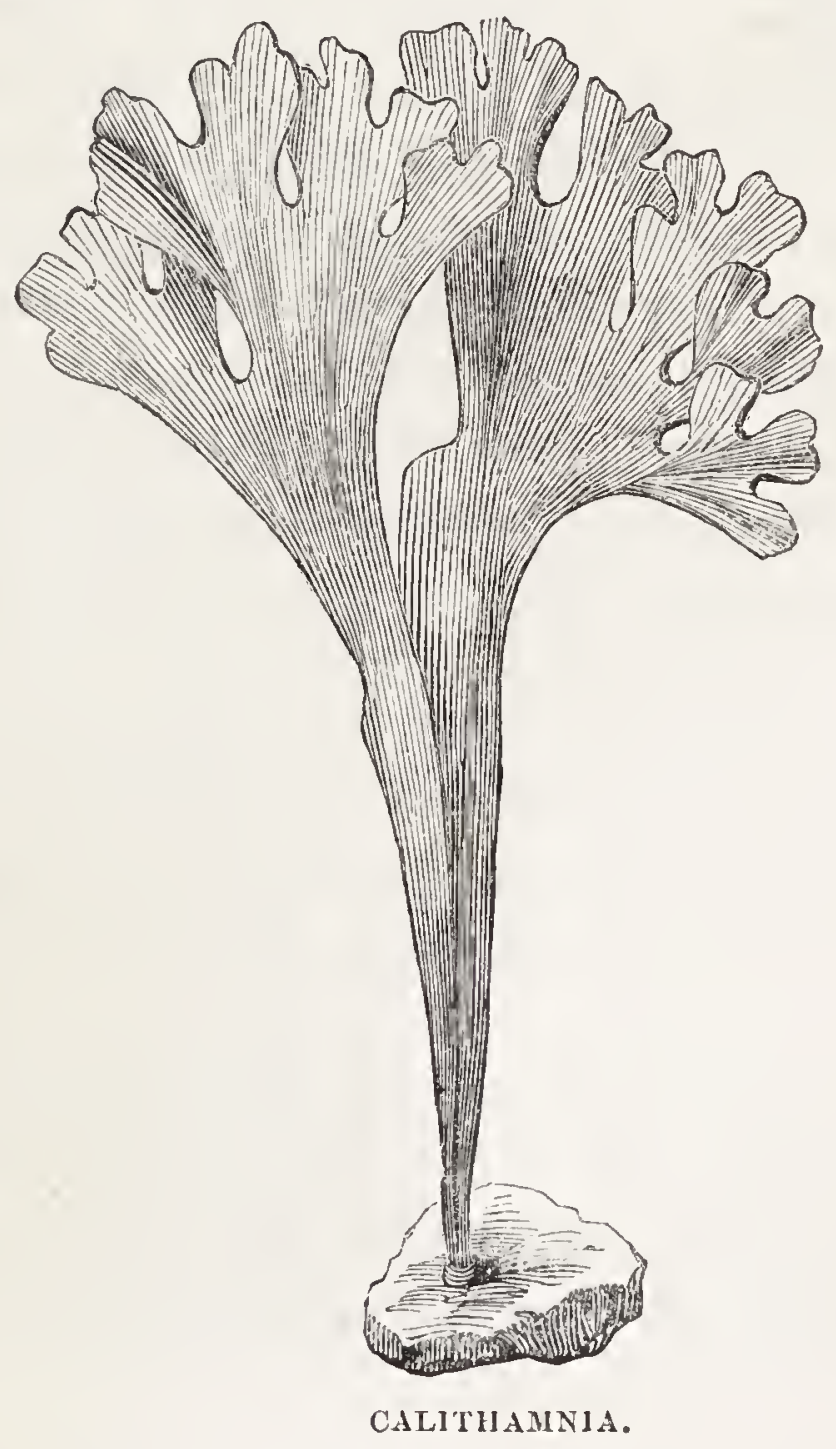


the external colouring is absent, and which were long considered animal formations, owing to their coralline nature, but reveals their true nature by their internal structure.

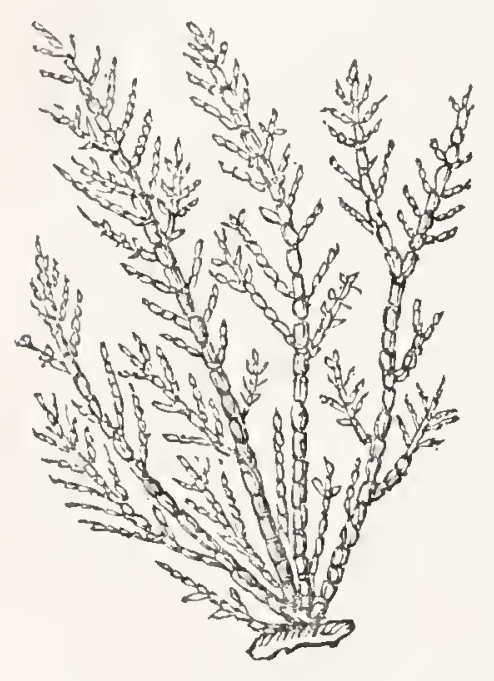

CORALLINA OFFICINALIS.

Iceland Moss (Chondrus crispus) which is found in incredible quantities on the coasts of the British islands, also belongs to the family of the Rhodosperms.

On being boiled, it almost entirely dissolves in the water, and on growing cold, becomes a colourless, nearly tasteless, jelly. The poor coast inhabitants of Ireland and England have used it for food during a lengthened period, and it has also been introduced into the pharmacopoia in the last twenty years under the name of Carrageen Moss. Similar nourishing jellies, which can also be employed as glue, are obtained from several exotic weeds, among others from the Gracillaria spinosa of the Indian Ocean, which the Salangane (Hirundo esculenta), is said to employ principally in the construction of its edible nest.

The steeply shelving walls of the south coast of Java are covered with luxuriant undergrowth to the extreme verge of land: even Pandanuses take root on the steep walls themselves, and look down by thousands into the surging sea below.

In course of incalculable years, the surf has worked deep bays and cavities in the calcareous rock: and in them the Salangane builds its nest. Where the sea rages most, flocks of them will be seen hovering. They fly purposely through 
the thickest foam, and seek their food in the seething surf. From a projecting peak, the orifice of the cavity Gua Rongkop may be seen, at one moment entirely beneath the waves, and then peering out again, and the swallows flying in and out with lightning speed. While, at a short distance from the coast, the blue sea is quite calm, it never ceases to boil and roar at the foot of the rocky walls. The most beautiful rainbows are reflected from the incessantly rising spray.

What marvellous instinct can have induced the birds to attach their nests to the high, arched, gloomy roof of these caves? Did they, perchance, hope thus to escape the pursuit of man? If they did so, their hopes were vain; for his avarice teaches him how to gain access to the most inaccessible things. At the Guagede Cave, the ridge of the coast wall is 80 feet above the level of the sea at ebb-tide: the wall bends concavely inwards, but forms a promontory 25 feet above the sea, which excellently assists the nest collectors; for they let down a ladder, made of ratan cords, perpendicularly from its edge. The roof of the entrance to the cave is only ten feet above the sea, which covers the whole of the bottom even at ebb-tide, while at the flood the opening of the cave is closed by every rolling wave. The interior can only be reached at ebb-tide with a perfectly caln sea, and even this would be impossible were not the roof perforated by a number of holes. On the projecting points in these holes, the boldest and strongest of the collectors stands, and attaches ratan cords to them, which hang down from the roof from four to five feet. To the lower end other long cords are fastened, so that it forms a hanging bridge all along the cave, following the inequalities of the roof. The cave is 100 feet wide, and 150 
feet long to the extreme northern point. Other caves are 500 feet long. If we have admired the daring of the crags men of St. Kilda, who oscillate in the air, we must not pass by the courage of these Javanese cave-plunderers. Before they hang down the ladder's to collect the birds' nests, a solemn prayer is addressed to the goddess of the South Coast, and at times a sacrifice offered at the grave, where the first discoverer of the bird-nest cave is said to lie. Thus, in all zones and at every stage of civilisation, man is led by an inner voice to rely on the invisible powers, where a great and dangerous enterprise is before him. The Salangane, as we have said, builds its nest of sea-weed, which it macerates in its maw, and then expels again through the beak. The layers are continually placed on the edge of the nest till the whole is finished, and they harden in the air. When the time for the harvest approaches, a few collectors go down into the hole daily, and examine in what state the young brood is. If they notice that the young are nearly all fledged, the collecting is begun. These nests form the first quality: those with still quite naked birds, the second; while those which still contain eggs and are not ripe, are counted as the third. On the other hand, those nests are over..ripe, black and useless, in which the young are already feathered. All the young and the eggs are thrown in the sea. The nests are taken thrice a-year; and the birds incubate four times. In spite of this huge extermination, their number does not'decrease, either because many young birds have flown out before the day of execution, or other swallows come from caves that are still inaccessible. From this cave, 50 piculs are annually obtained, for which the Chinese pay from $£ 350$ to $£ 450$, or 
about three guineas per pound. A picul, on the average, contains 1,000 nests. If we assume each collection to produce 50,000, and calculate two birds to each nest, we arrive at a total of more than 100,000 swallows, living together in the Javanese ocean-caves.

In the interior of the island, too, in the limestone grottoes of Bandong, the Salangane nestles, though in much smaller numbers, for scarce 14,000 nests are collected there in the year. In these caves, swallows and bats live together, but do not disturb each other; for when they are not breeding, the former fly out of the cave at sunrise and do not return till late in the evening. The collectors suspect that they seek the sea-beach.

In Sumatra and the other Sunda isles, birds' nests are also collected; but nowhere in such quantities as at Java. In China, they are first cleansed of all foreign constituents by special instruments, and then taken to market. In being prepared for the table, so many spices are added that they are the greatest of Chinese dainties; but, in themselves, they are nothing but fine jelly.

The Japanese have long found out that these expensive birds' nests are only softened Algæ. Those sea-weeds which are found in large quantities on the coast of Japan, are powdered by them and boiled into a thick jelly, which they pour out in long pipes like maccaroni, and introduce into trade under the name of Jin-jan, as an artificial birds' nest substance. The Dutch call it Agar-agar, and eat large quantities. Boiling is alone necessary to reconvert it into jelly. How great the use of this vegetable jelly must be in Japan is proved 
by the fact, that it is quoted as a production of the land in geographo-statistical works.

Thus we see that the Algæ, which were considered by the Romans so valueless, that, when they wished to indicate any thing extremely paltry, they used to say it was worse than sea-weed cast ashore - projectât vilior algâ - do not at all deserve to be thus looked down on. Man might rather be reproached because, through ignorance or prejudice, he has hitherto so little used such a rich source of nourishment, which nature offers him so abundantly on all flat, rocky coasts. For not only are the species we have instanced esculent; but several others of the most common sea-weeds in the Atlantic and the German Ocean (Fucus nodosus and vesiculosus, Laminaria saccharina), as well as the gigantic Alarix and D'Urvillex of the cold latitudes, afford nourishment. Would it not be possible to prepare cheaply the nutriment contained in sea-weed, so that it might be transported for long distances? The question certainly deserves some attention; especially at a time when the supply of the necessary provisions for a growing population becomes daily more difficult.

Finally, we may remark that the higher sea-weeds require salt for their growth. In the Baltic, the number of marine Alga is much smaller than in the open sea, whose waves wash the Scandinavian peninsula at the same latitudes. But it does not follow from this, that salt can be regarded as nutriment like water, carbonic acid, and air; but that it is rather an irritating medicine, which heightens the organic activity of the organism, much in the same way that certain salts aid digestion in the higher animals. 
Most of the Algx are covered with a thick slime, which is of great importance for their preservation, as the water can glide more evenly over them, and thus their power of resisting the storms is augmented.

The Sponges, of which fifty-six species are found on the British coasts alone, belong to the problematical creatures which stand on the border line between the animal and vegetable kingdoms, and are attached to both in turn by naturalists. As, however, it wants both sensation and motion, we have good reasons for classing the Sponge among the marine plants.

The body of the Sponge consists of numerous horny fibres constantly intersecting each other, in which very many pointed pieces of lime are embedded, and is traversed by a system of water-conducting canals, which commence with small pores at the surface, and pour their contents into the larger vessels. These, too, are finally discharged through larger openings. According to the observations of Dr. Grant, the water flows in through the smaller pores, and out again through the larger canals, so long as the Sponge remains alive. These constant currents supply it with the necessary nourishment, and maintain the change of substance, which these low creatures require as much as the highest beings. All the horny parts are covered with a semi-fluid viscous substance, in which the simple life of the Sponge lias its residence. It is this which secretes the firm parts, forms the real spongeous skeleton, and makes the mass larger.

Sponges are propagated in a strange way. At certain seasons, the walls of the canals are covered with countless small dots or bodies, which are the spores, or young eggs, 
of the sponge. As they become larger, they grow covered with cilia, and soon quit the maternal body, to flow out into the open sea. Here they swim about freely for a time, by means of the constant motion of their cilia, till they attach themselves to some fixed object, in which they can await their further development. From this moment, their wanderings cease, and a quiet vegetative life is substituted for the adventurous nomadizing. From this history of their development, it might seem as if the Sponges could not be denied an animal nature; but the spores of the sea-weed enjoy the same privilege of a moveable life, so that this is no distinguishing mark between the animal and vegetable kingdoms. The common sea, or bathing Sponge (Spongia communis), which plays so useful a part in our households, is usually obtained from the islands of the Archipelago, where it is attached to reefs, and forms a considerable article of trade. The West Indies, also, supply useful Sponges. Burnt Sponge is still employed as an effectual remedy in cases of goitre, and owes its medicinal power to the iodine, bromine, and carbonate of lime which are found in the ashes. 


\section{CHAPTER XIV.}

General Remariss on the Geographical Distribution of the Animal and Vegetable Kingdoms. - Dependence of all created Beings on Space and Time. - Influences wilici deternine the Distribution of Marine Creatures. - The eight vertical Regions of Organic Life in the Egean. The Inimabitants of the Red Sea.

WHEN we depart from our home, and visit distant countries, we gradually find ourselves surrounded by a new animal and vegetable world. If, for instance, we cross the Alps into Italy, the birch, the pine, the briar, and the oak, no longer meet our glance, and are very rarely visible; while lemons, olives, and oranges, grow very luxuriantly, until we even find palms on the Mediterranean coast. Thus our original comrades desert us on a lengthened journey, one after the other, until, at the end of our travels, we find ourselves surrounded by entirely new associations.

We may traverse the globe from one pole to the other, or cross the equator; but, in every direction, north and south, east and west, nature gradually changes her garb, never again to assume it. The plants and animals of the temperate and cold regions of the north, vary from those of the corresponding climate in the southern hemisphere and in the tropics. Each portion of the globe supports its peculiar inhabitants.

Similar changes in the vegetable and animal forms meet our sight, on ascending from the plains to the summit of lofty mountains. 
At the foot of Mount Etna, blossoms the luxuriant flora of a milder sky - the palm-tree (Chamorops) and the pomegranate, the cotton-plant and the sugar-cane. If we ascend, the cool shadow of splendid chestnut-groves meets us, followed by the oaks, till we at last attain the desolate regions, where all vegetation is palsied by the intense coldness of an eternal winter. With every thousand feet we have risen, we seem to have approached so many degrees nearer to the pole.

This wondrous change of form, which adorns the different countries and heights of terra firma with such an incessant variety of living things, is repeated in the ocean kingdom. Here, too, we find every larger division of the sea provided with the inhabitants peculiar to it. Here, too, we find, in perpendicular descent from the surface, similar changes in organic nature, as on land in the different elevations above the level of the sea.

Thousands of perished types of animals and plants, which have flourished, and in their turn decayed, give us the valuable lesson that everything created is subjected to time. Only at one period of the planetary life did each genus or species find all those conditions united, in which it could reach its greatest perfection. But the surrounding nature is imperceptibly modified in the course of centuries. The once blooming races gradually pine away. They can no longer maintain the struggle with the new forms which, being favoured byaltered circumstances, appear on the scene in all the strength of youth; and, on their decadence, only the consolation remains to them, that a similar fate impends over the haughty parvenus by whom they have been thrust aside.

All created beings are as dependent on space as on time. Of the countless animal and plant varieties which inhabit 
the globe, each finds only at one spot of it all those climatic influences and conditions of soil combined in which its life attains perfection. Some, gifted with a more yielding or a more energetic nature, occupy a wide space on the surface of the earth; they are found enjoying a healthy existence, spread over entire hemispheres. Others, again, have to be contented with their own home, and are not unfrequently limited to a single bay, a single mountain slope.

In this close, mysterious connection between the producing soil and its productions, is doubtlessly hidden a great part of the magical charms of nature. Here all is harmony ; we feel it in our heart-of-hearts, and our eye rejoices at the union of form and colour, as our ear does at the sound of fine music; and what creation of any human artist could be compared with the pictures, whose endless, every changing gallery the Master of all worlds displays to us in every zone from Pole to Pole! They pass away in a second ; but every minute brings new ones never before seen. Fortunate is the man, who, by attentive loving observation, has gained a deeper insight of their beauties! To him every walk. reveals sources of the purest artistic enjoyment.

'The causes that attach animals and plants to certain localities are partially clear and patent to us. The warmness or coldness of the sea, produced by currents, geographical position and depth, quiet or troubled, pure or impure water, abundant provision or the want of it, the fineness or softness of the soil, sufficiently explain, in many cases, why various genera of marine creatures are here found in large numbers, or there are entirely absent. A glance at their structure teaches us sometimes the physical qualities, which their residence must necessarily possess. We see at once if an Alga requires the 
protection of an unruffled calm or can defy the storm; if it is found to anchor on the rocks, or to sink its roots into a yielding soil. Many a Mollusc can only breathe in the purest water, or requires hard stone, to which it attaches itself. In other soft-bodied tribes, on the other hand, the respiratory organs are protected against the the admission of shifting land, and permit them to hide from their foes in the mud.

In many cases, however, the reasons which decide the distribution of the Marine creatures remain a mystery : and, in the same way, as no one yet can explain why the family of Quinine trees only grows on a narrow belt on the Northern half of the South American Andes, or the Tea bush is confined to a small corner of Asia; it is impossible to explain why, under suitable climatic influences, and apparently equally favourable circumstances, the tropical sea supports numerous coral reefs, and then again dashes against shores which are quite free from them.

There are evidently, in addition to the known influences, others working in secret, which draw round each being the mysterious circle, beyond which it must not pass. Their explanation is partly reserved for the future, and is among the most interesting questions of the present. Many may, perhaps, remain eternally closed to the human mind.

The geographical distribution of the plants and animals found on land, is indubitably much more easily decided, than that of the denizens of the sea. The inquirer can mount the loftiest mountains to the last trace of vegetation; and, far above these summits, his eye pierces the pure atmosphere, in which the Condor soars in solitary majesty; he can traverse the valleys, or descending into the interior of the earth, even survey and collect the subterranean flora; but he cannot walk over 
the submarine meadows or through the thickets of the fucine forests ; he is not permitted to sink into the depths of ocean.

But, in spite of these natural obstacles, his investigating mind, connected with his insatiable curiosity, has granted him means to consult the abysses and their secrets, and partly to raise the veil, behind which the life of the sea is hidden. Armed with the dredge, he filches from the bottom of the sea, Plants, Polypes, Molluses, and Echino-dermata, and learns the different provinces they select for their abode; or he lowers the line for hundreds, nay thousands of fathoms, in order to draw up with it specimens of Corals, and protozoic shells.

To the lately deceased and much regretted Professor Forbes, of Edinburgh, we are indebted for the first detailed and extended investigations of this nature; and we fancy we cannot give our readers a better idea of what the bed of the sea looks like, than by informing them of the results of his examinations both in the ocean and in the British waters.

The distribution of Marine animals, according to Forbes, is regulated by three principal influences (climate, constituents of the water, and depth), which are modified in many ways by various other secondary or local conditions.

The influence of the slightly salted water of the Black Sea is certainly more the cause than is the climate, that the Medusæ, which are found in such numbers of families and individuals in the Straits of Gibraltar, gradually decrease, the nearer we draw to the Greek waters; and the Zoophytes also grow scarcer and decrease in size in the Eastern Mediterranean. Yet Corals, for instance, are found in the Levant sea, but are too small to be employed in trade. Many species, characteristic of the Mediterranean, are no longer found in the Greek waters. According as the soil is composed of rock, sand, 
slime, or gravel, or is naked or covered with Algæ, the number of given species also varies. The appearance of Sponge often depends on the presence of isolated submarine pinnacles, which rise from the deep water near the coast. As the greater portion of the sea-bed is formed of mud, the Bivalved Molluscs surpass the Univalved in individual members, but ^ not in the variety of species. Where the ground is covered with Algæ, the naked Molluscs (Dorides, Eolids, Tritons) are more frequent than elsewhere; where it is rocky, thick-shelled Gasteropods and active Cephalopods prevail. There are but few species of the soft or rayed animals, which appear without distinction on every soil. The permanent or temporary admixture of soft water has a great influence. Rivers produce large and slimy districts, which offer a peculiar fauna; and periodical torrents are frequently dangerous to the life of several species.

In the Eastern Mediterranean, the marine creatures are divided according to the depth, into eight well defined regions or provinces, which are distinguished from each other by regular groupings of the inhabitants. Certain species are restricted to a single region. Others extend over several provinces, though they do not cross certain frontiers above or below.

The first region or littoral zone extends from the highest water-mark to twelve feet below the level of the sea. The uppermost portion, which lies between ebb and flow, and therefore remains exposed to the air for several hours daily, occupies only a narrow space, for, in the Mediterranean, the tides are so scarcely perceptible; still it is inhabited by some characteristic species. In the water belt immediately beneath it, are found the species most peculiar to the Mediterranean, and 
which most clearly reveal the influence of the climate; for their vivid colouring reminds us of the southern tropical seas. Only in this lower demesne of the highest region, do we notice regular horizontal limitations of species in the Eastern Mediterranean. Thus, within this belt, the rocks on the coast of Asia Minor, are distinguished from those of the Archipelago, by the great quantity of a splendid sort of Coral (Cladocora cespitosa), which grows in clusters six to eight feet below the level of the sea. In the protected bays of Lycia and Caria, within this region, also grows an enormous quantity of gaily coloured,

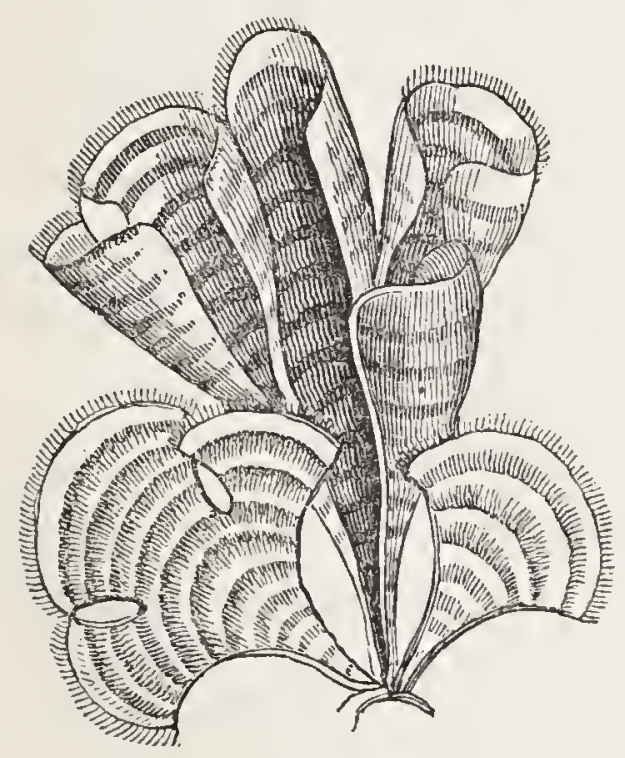

PADINA PAVONIA. strangely formed Sponges, while, at the Cyclades, the lovely Red Sea Anemone (Actinia rubra), occupies the corresponding space.

The Padina Pavonia is every where the characteristic Alga of this belt; and between its graceful fronds Crustaceans may be noticed swimming about, while in the crevices of the rock, on which it grows, lie numerous fish of the Blenny and Uranoscopus families, which, like all the other marine animals of this province, are remarkable, for their lustrous colours. The inhabitants of the lower section of this narrow, but various zone, are equally characteristic, especially those that live on the smooth bed of the sea covered with sea-grass (Zostera Marina).

Here the Pinna Squamosa is principally found; and many places swarm with Cuttle-fish. An infinity of Rissoa, small graceful Univalves, live on the leaves of the Zostera. 
The second region, which extends to a depth of ten fathoms, is distinguished by the appearance of large Holothuria, or Sea Cucumbers.

In the third region (10 to 20 fathoms) Caulerpa prolifera, and handsome pea-green sea-weed and Zostera oceanica are found, but cease at the lowest limit. This is a transition zone, which offers but few peculiarities. The large Holothuriæ are still numerous.

The fourth region (20 to 35 fathoms) is rich in Algæ (Dictyomenia volubitis, Sargassum salicifolium); but especially in calcareous corallines, which are found here more frequently than in any other zone. 'There is also a large number of Sponges, and among them some of the handsomest species introduced into trade. Nullipores are found in large quantities.

In the fifth region (35 to 55 fathoms) Algæ are much rarer than in the former; Sea Urchins and Star Fish, on the other hand, more numerous; Polypes not numerous.

In the sixth region ( 55 to 79 fathoms) the rocky ground is usually covered with Nullipores-vegetable creations formerly counted among the Zoophytes, on account of their calcareous nature. Algæ have become extremely rare; though a large number of herbivorous Molluscs live here, which find their food in the vegetable Nullipores.

In the seventh region, too ( 80 to 105 fathoms), the sea-bed is remarkably rich in Nullipores. The herbaceous Algæ and naked Molluscs have entirely disappeared. Polypes are scarce; but Sea Urchins, Stars, Crustaceans, and tubicolous Annelids still numerous.

In the eighth region (105 fathoms to 1380 feet below the surface), the fauna is distinguished from that of all the higher zones by the presence of peculiar species. Neither its 
limits, the number of species, nor individuals, diminish with the depth. Foraminifera are extremely numerous in the sand of this region, and seem to be a different sort from those of the higher zones. No plants are found. At a depth of 300 fathoms animal life also probably ceases.*

Of the varieties that occupy a broad vertical space, more than one half are such as have also a wide geographical distribution.

The Conchylia, and other animals of the lowest zones, are generally either white or colourless; while those in the-higher are remarkable for their splendid colouring. The influence of light may be clearly recognized from this fact.

* D'Orbigny divides the produetions on the shore of the Bay of Biscay into six zones: the first extending from a French font below the line of high water to a depth of 20 feet; the sccond, from 5 to 30 feet in depth; the third, from 15 to 35 feet; the fourth, from 20 to 40 feet; the fifth, from 30 to 60 feet; and, lastly, the sixth, from 40 to 100 feet, beyond which in thcse seas there is no regetation.

There are thirty-four species of Ulve growing betwcen the first and sixth zone; in the latter only $U$. tomentosus, which he considers to be a polypus; sixty-three species of Fucns, of which the $F$. pygmaeus and $F$. amplibius alone belong to the first zonc; while the $F$. loreus, $F$. fibrosus, $F$. sanguineus and $F$. coronopifolius, belong to the sixth zone; twenty nine speeics of Ccramium, of which none are found in the first zonc, nor do they extend beyond the fifth, in which occur the C. coccineum and C. cegagrophilum, the latter of which is rarc. Two species of Diatoma, D. rigidum and D. flocculosum, oceur in the sceond zone, in which are also found the Zostera marina and Z. Mediterranea, but the latter rarely.

The numerical proportions of plants in the different zones are as follows:-

$\begin{array}{lccccc} & \text { Ulva. } & \text { Fuci. } & \text { Ceramia. } & \text { Diatoma. } & \text { Zosterc. } \\ \text { 1st zone } & 4 & 2 & 0 & 0 & 0 \\ \text { 2nd ", } & 14 & 15 & 9 & 2 & 2 \\ \text { 3rd ", } & 6 & 13 & 12 & 0 & 0 \\ \text { 4th " } & 6 & 13 & 4 & 0 & 0 \\ \text { 5th ", } & 0 & 6 & 4 & 0 & 0 \\ \text { 6th " } & \text { I(?) } & 5 & 0 & 0 & 0 \\ & & \text { Memoires du Musent } & \text { M. tom. vi.-W. F. A. }\end{array}$


If one species is found in several regions, it only attains its highest development in one of them.

Just, as on scaling a mountain, we seem to be drawing gradually nearer to the pole, as the whole of nature assumes a more northern character, so in the sea each increase of depth is equivalent to a growing distance from the Equator.

After this short short sketch of the division of the organic world in the Greek waters, it will not be uninteresting to cast a glance at the existing relations in the British seas.

Here the littoral zone, which, owing to the strong tides, forms a much wider belt than in the Mediterranean, forms four subdivisions, each of which is remarkable for the predominance of special Fuci and Conchylia.

The highest water-mark is occupied by Fucus canaliculatus and a Shore-Mussel (Littorina rudis), followed in the second subdivision by the Lichinæ and the Common Mussel (Mytilus edulis). In this sub-region, as in the third, the rocks are nearly always incrustated with Acorn-shells; so that at ebb tide, a broad white belt, visible at a great distance, runs along all rocky coasts. In the third sub-region, the Common Varech or Kelp (Fucus articulatus), predominates, with the Yellow Periwinkle (Littorina littorea), and the pretty Purple Shell (Purpura lapillus.)

In the fourth and last subdivision, the above-mentioned Fuci yield to a new species; the Fucus serratus, and new varieties of shells, such as the peculiar Tops (trochi) make their appearance.

Below the lowest verge of the ebb, at a depth of about 15 fathoms, extends the zone of the Laminaria, whose place is taken on sandy coasts, by grass-wrack meadows. At the extreme edge of this region, Nullipores are the predominating 
plants. From the 15th to 20 th fathom, is the Coralline zone, a province containing many peculiar forms of animal life; but prominent forms of plants appear banished. The majority of its inhabitants, to which our valuable fish belong, are predacious.

Below 50 fathoms, commences the region of the deep sea Corals, in which real stone polypi, of considerable extent, are met with. Numerous Echini and Star-fish are also found in these greater depths.

The denizens of our northern seas display to us also a great difference from those of the Greek waters, as might be expected from the considerable variation of clime; but even on the coasts of the British Isles the submarine nature changes with the geographical position. The ocean flora and fauna of the south-west coast of England have a perceptible variation from those of the Irish Sea; and these again from those of the Hebrides. Many animals are found in large numbers on the western coast, and are entirely absent on the eastern. At the west of Ireland, there is a spot distinguished from all other parts of the coast by the presence of a Sea-urchin, which is only met with again in Spain.

In conclusion, we will carry our readers to the tropical waters of the Red Sea, where very different life-pictures are displayed to them. The submarine animal and plant world has undergone an utter metamorphosis, and nothing will remind them of the denizens of their home seas.

It would be a difficult task to catalogue the immense number of conchylia, which cover the bed of the Arabian Gulf. Univalves and bivalves rival each other in colour and size; and while those horn-shells, which grow to a length of one and a half feet are found there, the giant Tridacna, which is five feet broad, forms entire submarine banks. Three species of bivalves are 
highly esteemed for their pearls and mother-o'-pearl: a shell, chiefly found off the Egyptian coast, a splendid red Pinna, and a bivalve resembling an oyster. 'The pearls of the first are rarely clear, but sought for their size and lustre; the second supplies a handsome white mother-o'-pearl, with a delicate, reddish shading; the third, called Isulu el berber, is exported in great quantities to Jerusalem, where it is used for mosaic, or worked up into snuff-boxes, rosaries and crucifixes. In addition, the Arabs obtain a large portion of their domestic utensils, and their personal ornaments, from these submarine treasuries. The Nautilus serves them as a cup, the Hornshell for a jug, and a Bivalve for a saucer or plate. Most of the houses at Teliama are formed of corals, so that each hut offers a small naturalist's cabinet. The quantity of Zoophytes and, Algae, which has given that gulf the name of the Weedy Sea surpasses all conception. When rowing slowly over them; they resemble submarine forests. Some grow perpendicularly like cypresses; others extend their branches, like oaks: and between this larger growth, the entire ground is covered with a rich green carpet of creeping plants. The Corals also attain an astounding size. Some, like the Mrandrines, always retain a regular specific form, while others assume the strangest shapes, and model themselves after the objects they cover. As regards the other inhabitants of these waters, the remark must suffice, that the Red Sea swarms with countless Medusæ, Salpæ, Crustaceans, and other marine animals. It is also remarkably rich in the most beautiful Sea-urchins: some flat and nearly round, others covered with thorns, which at times are thicker than the quill of a goose's feather. 'The adjacent, lifeless, Arabian and Nubian desert, forms a strange contrast to this abundance of the ocean. 


\section{CHAPTER XV.}

Phosphorescence of time Sea. - Cause of the Phenomenon. Mamiaria Scintillays. - Glistening Anemones and Beroës.Intense Light of the Prrosoma Atrantica. - Phosphorescent Marine Plants.-Passages from Brron, Coleridge, and Crabbe, relating to the Pilosphorescence of the Sea.

$A^{N Y}$ one who wanders, late in the evening, or amid the gloom of night, along the sea-shore, will be surprised at times by a magnificent scene. Bright flashes of light emerge from the lap of the waters, as if the sea wished to restore to the obscured sky the light it had sucked in during the day. On approaching the edge of the rising tide, and inspecting more closely the sparkling of the dashing wave, the advancing water appears to cover the sand with a layer of fire. On passing the hand over the humid soil, bright spots like stars flash out; and, striking the waters seems to arouse slumbering flames.

The same wondrous sight, also, delights the sailor, who draws his furrow through the broad deserts of ocean, especially when his course takes him through the tropical seas.

"When a vessel of war cleaves through the foaming waves with a smart breeze, a person standing at the bulwarks can never gaze his fill of the scenes which the approaching wave offers him. So soon as the exposed side of the vessel heels 
out of the water, bluish or reddish flames appear to shoot with the speed of lightning upwards from the keel. Indescribably splendid, too, is the scene in the seas of the tropical world, which, on a dark night, a shoal of sporting dolphins presents. As they dart through the waves, their path is marked by sparks and intense light. In the Gulf of Cariaco, between Cumana and the peninsula of Maniquarez, I often revelled in this spectacle for hours."-Humboldt's Views of Nature.

But, in the colder regions of the ocean, this remarkable phenomenon is also displayed in all its brilliancy. On a dark and stormy September night, on the road from the Sea-lion Island of St. George, which we visited in a previous chapter, to Unalashka, Chamisso saw a glorious phosphorescence, finer than he had - ever seen between the tropics. The flashes of light attached themselves to the edges of the sails washed by the spray, and continued to glisten in another element. Ermann also saw, at the southern promontory of Kamtschatka, at a temperature of no more than $4^{\circ}$, the sea equally phosphorescent with what he had ever seen during his seven months' stay in the warmest seas. According to him, it is a false idea that the phosphorescence is in any way favoured by a high temperature.

In lively colours, Darwin depicts the splendid scene which the sea offered him, in the latitude of Cape Horn, during a very dark night. A fresh breeze was blowing; and all those parts of the surface which, by day appeared a white foam, now gleamed with a pallid light. The ship impelled two waves of liquid phosphorus before it, and left a long, twinkling, milky track behind it. So far as the eye could reach, the crest of every wave glistened. 
When "La Venus" was anchored off Simon's Town, the waves emitted such a powerful light, that the room in which the naturalists of the expedition resided, was lit up as by a flash of lightning. Although above fifty paces from the serf they tried to read by the light of the ocean phosphorescence; but the development was each time too short to allow of this.

Thus, we find the same brilliancy which illumines the nocturnal ocean, between the tropics, with flames of glowing points, and which, on the coasts of the German Ocean, arouses the susceptible mind to lively admiration, also produced in those seas which dash round the most southern points of the continent.

What is the cause of this so glorious, universally-extended phenomenon? How is it that, at certain periods, fire dashes forth from the lap of such an antagonistic element? Instead of delaying the reader by the unfounded hypotheses of the elder naturalists, and explaining to him the errors of the past, we will sooner take up the matter with him at the present stage of our knowledge.

It is now known with certainty, that nearly all the lower animals, especially the Acalephr, with their fry, and also many infusoria, polypes, molluses, annelids, and crustaceans, possess the power of shining, and hence they produce the wondrous phenomena of oceanic irridescence. If we reflect on their enormous numbers, we shall not feel surprised that such grand effects are produced by such insignificant animals.

In our northern seas, it is chiefly an animalcule of gelatinous nature, Mammaria scintillans, which represents on the surface of the water the splendid picture of the starry sky.

If a vessel be filled with the gleaming water, the little 
Mammarix, of the size of a pin's head, may be seen by daylight. Generally transparent as crystal, they only display at one point a milk-like dot. Under the microscope, they are clearly seen to be globular animals, with a hollow at one part of the surface, from which a rather long tentacle projects, which moves slowly about, as if in search of food.

That the light emanates from these animals, can now be most perfectly proved: for if the phosphorescent water is filtered, it entirely loses the power of shining, but the animals that remain in the filter glisten on being shaken. Further, the intensity of the light is always in relation to the quantity of the Mammarix. If, lastly, a bottle filled with seawater, in which are some of these animals, is shaken in the dark, glistening points are seen falling and rising, and precisely the same thing occurs in day-light.

A blow, or some external irritation, is needed to produce the irridescence in the Mammarix, and most of the other oceanic glistening animals; but there are other creatures (such as Nerë̈s noctiluca, Medusa pelagina, Monophora noctiluca) which spread around them a weak light voluntarily.

Usually, the power of shining is inherent in the external slimy coating of the body. In other cases, the phosphorescence is connected with special organs, or spread over the whole of the body.

M. de Quatrefages observed in the Channel some Annelids, in which the muscular substance of the feet was the sole abode of phosphorescence. In the ciliograde Medusæ (Beroë, Cydippe), the cilia, by whose oscillations the animal moves, sparkle in the dark with a bluish light.

In the Protocharis, one of the infusoria, Ehrenberg dis- 
covered gleaming organs, whose large-celled structure, full of a gelatinous substance, bears a resemblance to the electrical organ of the Gymnotus and of the Torpedo.

"If the Protocharis be irritated, various flashing dots appear on the cirrus, which gradually increase in size, and illumine the entire cirrus; at last, the living fire runs also over the back of the Nerëidic Animalcule, so that it looks, under the microscope, like a burning lucifer-match, with a greenish yellow light."

Among all the organic phosphorescent animals, a Salpa (the Pyrosoma atlantica) appears to produce the most intense light. The Pyrosoma is produced by the aggregation of a large quantity of small individuals, in which the mouth lies to the outside, the vent inwards, near a small cavity. The entire mass of these collected animals thus forms a cylinder open at one end. By a common contraction of all these animals, the central organ is expanded or contracted, and thus the motion is probably effected. Behind the mouth of each individual is a soft opaque substance, of reddishbrown colour and conical shape, in which thirty to forty red points may be distinguished under the microscope; and it is this matter which possesses the exclusive power of emitting light. Herr von Bibra tells us, in his "Voyage to Chili," that he once caught six or eight Pyrosomæ, by whose phosphorescent light he was enabled to read in his perfectly dark cabin. He read to a friend, who lay ill in his berth, a short description of these animals, from a zoological vade-mecum, by their own light. Although not irritated and in perfect darkness, the slightest touch was sufficient to make them glisten 
at once. The light of the Pyrosoma atlantica is a bluish green, with a very beautiful modification of the tinge.

In the Pholades, which dig their abode in the hard stone, as the Bivalves do in the loose sand, the entire body is filled with light. Pliny gives us a short but living description of the phenomenon: "It is in the nature of the Pholades," the reverend Roman writes, "when the light has been removed, to emit a peculiar lustre, which grows larger the more humidity they contain. When eaten, they glisten in the mouth and on the hands. Hence the falling drops shine on the clothes and the ground; so that, doubtlessly, the light we admire in them is connected with their juices."

The observations of Milne Edwards also agree with this view; for, on proceeding to immerse some Pholades in spirits of wine, he saw a glistening matter drip from them, which dropped to the bottom of the vessel, and there continued glistening.

Several fish also possess the faculty of shining. The Swinming Shad, or Moon-fish, that strange abortion, emits a phosphorescent gleam; and the Funter (Trigla) is said to glisten and sparkle at night, so that rays of light may be noticed, extending far along the water sometimes high and sometimes lower.

With reference to the glistening of the larger marine animals, however, Ermann remarks, that he so frequently found in the belly of the transparent Salpa pinnata, microscopical crustacean glistening animals, half alive and most lively, others already half-destroyed, that the light of the larger denizens of the ocean may safely be ascribed to the same influences. Fish, then, resemble the great ones of our 
earth, who only shine so brightly, because the little folk supply the light.

According to Bennett, a Shark (Squalus fulgens), first described by him, is distinguished by an extraordinarily powerful diffusion of light. A captured animal of this sort, when taken into a dark room, produced a very remarlsable sight. The entire lower part of the body and head emitted a bright-green phosphorescent light, which gave the thus illuminated fish a truly horrific appearance. The light was permanent, and was not apparently heightened by motion and rubbing. When the Shark died, which did not occur till it had been three hours out of the water, the light on the belly first expired, and then, gradually, on the other parts, remaining the longest on the jaw and fins. The only part of the lower surface of the animal which did not glisten, was the black band round the throat.

Bennett fancied, at first, that the fish had been accidentally covered with phosphorescent matter from the sea; but this suspicion was not confirmed by the closest inspection; while the regularity with which the light covered certain parts of the body, its permanence during life, and disappearance after death, permitted no doubt that the apparition was a peculiar vital expression.

The smallness of the fins in this species of Shark, indicates that it is not very active in swimming; and as it only lives on plunder, and evidently belongs to the nocturnal animals, Bennett conjectures that it entices its prey by its phosphorescent power, just as torches are frequently employedin night fishing. 
Phosphorence, too, does not appear quite strange to the ocean plants. Thus, Meyen found, for a distance of nearly s00 miles, between $8^{0} \mathrm{~N}$. Latitude and $2^{0} \mathrm{~S}$. Latitude, the sea filled with a glistening plant, which, from this faculty, he christened Oscillatoria phosphorescens.

In water drawn from the sea, there appeared some fanshaped stars, like flakes of snow, from the size of a poppyseed to that of a small bean, and composed of these Oscillatcriæ.

Though the irridescence of the sea-rvaters is most generally produced by living light-bearers, it also depends at times on putrefying organic fibres and membranes, which owe their origin to the destruction of the original animals.

As Humboldt tells us, in his "Views of Nature," not even the most powerful magnifying-glass will at times detect animals in the shining water; and yet, whenever the wave strikes against a hard substance, and breaks with a spray, or whenever the water is shaken, a light glistens. 'The cause of this appearance is probably in the corrupting fibres of deceased molluses, countless numbers of which are dispersed through the water. If gleaming sea-water be filtered through fine muslin, these fibres and membranes are separated from it in the shape of glistening spots. Perhaps, orving to the countless array of molluscs that inhabit all tropical seas, we ought not to feel surprised, if sea-water even glistens when no visible fibres can be separated from it. Owing to the endless distribution of the decayed mass of Medusæ, the entire sea may well be regarded as a gelatinous fluid, which, though repugnant to man, supplies nourishment for fish. 
It is, therefore, evident, that the gleaming of the sea is not any magnetic or electric quality of the water; but is exclusively connected with living or dead organic matter.

But, though we know this, we have only drawn one step nearer to the solution of the mystery, without being able to explain its causes: and the question still remains - What is the immediate cause of the irridescence? To this we can, unfortunately, give no certain answer; and, as in all similar cases, we must attempt to explain it by more or less fortunate hypotheses, the following views of Professor Leuckart will probably furnish the best idea of the present position of science with reference to this interesting subject:-

"When we reflect that usually only the external slimy coating of the body glistens, in which a quantity of cast-off cuticles are constantly undergoing the procession of solution; and that this mass, even after leaving the body, and the death of the animal, retains the faculty of gleaming for some time,we can hardly refrain from the idea that the phosphorescence must be a simple chymical act depending on this solution. We need not allude to the phosphorus contained in animal substances, which is probably in some cases much more considerable than we are yet aware. It is more difficult to explain in this way the cases in which the entire substance of the body shines (as in the Pholas), or the muscular substance (as is noticed in some of the annelids), or the oscillatory cilia (as in the Ciliograde Medusæ), in which irritation or movement heightens the power of gleaming. We should be more disposed, in such cases, to think of the electric currents which, according to later investigations, are so frequently found in the organism, especially in the muscular substance, and whose equilibrium 
is disturbed by movement. But it seems incredible, that, in such an excellent conductor as water, the tension of the electricity should increase to such a degree, as a compensation for the development of light would necessarily presuppose. And hence we may also in these cases conjecture a similar production of light from chymical decomposition, unless we prefer to confess our perfect ignorance in the matter."

Equally small is our knowledge of the use or teleological im. portance of the phosphorescence. Why do the countless swarms of Mammarix sparkle and glimmer on our coast? It can hardly aid them in finding food; and, instead of protecting them against external foes, should sooner expose them to attack. Surely, however, so grand a phenomenon spread over the entire ocean must fulfil some equally grand object.

As the irridescence chiefly emanates from living beings, it is easily explicable that it is only unfolded in its full glory on clear evenings. In stormy weather, the entire easilyinjured gelatinous world of the lower marine creatures disappears into the calm serene depths, and remains there until the peace of the elements again entices them to the surface. Between the tropics, Humboldt saw the sea glisten most brightly on the approach of a storm, or with a heavy vapoury sky covered with clouds.

In the German Ocean, the phenomenon is most frequently visible on fine calm autumn evenings; but it is seen at every season, even in the extremest cold. In addition, the sea, when under apparently similar external influences, will glisten powerfully one night, and the next not at all. Months often pass, nay, entire years, and it does not display itself in all its beauty. Does this proceed from the peculiar circum- 
stances of the weather, or was there a great mortality among the Mammarix, or do they like to visit various parts of the coast in turn?

It is remarkable, that the ancients mention the phosphorescence of the sea so slightly, that the "Periplus" of Hanno probably contains the only passage in which we find the phenomenon shortly described. To the southward of Cerne, the Carthaginian navigator saw the sea burning, as it were, with streams of fire. Pliny, in whom the miracle of the Pholas dactylus excites such lively admiration, and who was certainly well acquainted with the phosphorescence of the sea, as the passage proves, in which he mentions the glistening fish "Lucerna" in a few dry words, has no exclamation of amazement at the glorious natural phenomenon. Even Homer, who accompanies the gloriously-patient Odysseus on so many voyages through the nocturnal waves, no where describes them as sparkling and gleaming.

In later poets only scanty references are to be found. Even Camoëns, whom Humboldt christens the "poet of the sea," for his excellent oceanic descriptions, forgets to sing the phosphorescence of the sea in his "Lusiad." Byron alludes to it in "The Corsair":-

"Flash'd the dip't oars, and, sparkling with the stroke, Around the waves phosphoric brightness broke;"

but contents himself, as we see, with the cold mention of the phenomenon, which, however, seems better fitted than any other to inflame the imaginative power of a poet.

In Coleridge's wondrous ballad, "The Ancient Mariner," 
we find the phosphorescence of the sea described with greater enthusiasm:-

"Beyond the shadow of the ship,

I watch'd the water-snakes;

They moved in traeks of shining white, And, when they reared, the elfish light

Fell off in hoary flakes.

"Within the shadow of the ship,

I wateh'd their rieh attire;

Blue, glossy green, and velvet blaek, They coil'd and swam; and every traek

Was a flash of golden fire."

The finest lines, however, yet written on this glorious subject, are found in Crabbe, and we quote them with real pleasure:-

"And now your view upon the ocean turn, And there the splendour of the waves diseern; Cast but a stone, or strike them with an oar, And you shall flames within the deep explore; Or scoop the stream phosphorie as you stand, And the cold flames shall flash along your hand: When, lost in wonder, you shall walk and gaze On weeds that sparkle, and on waves that blaze."

THE END. 





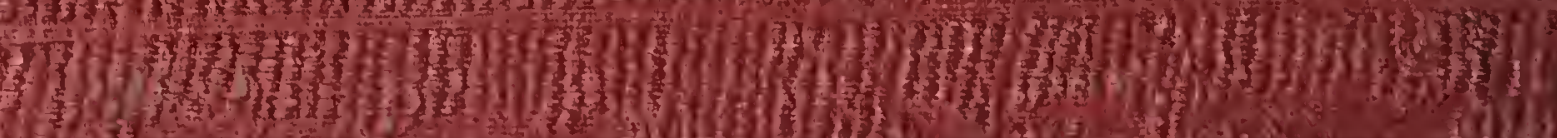

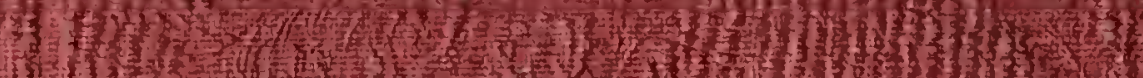

I I I

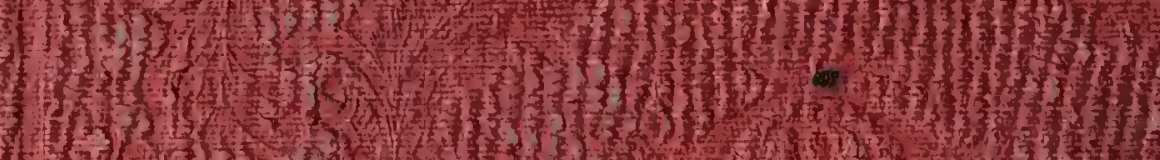

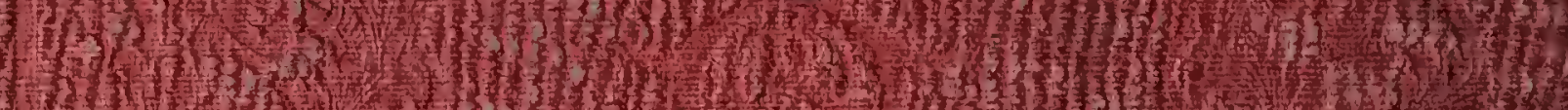

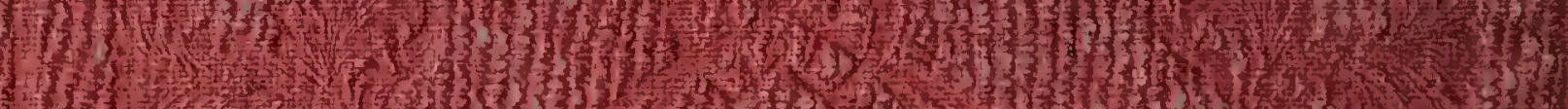

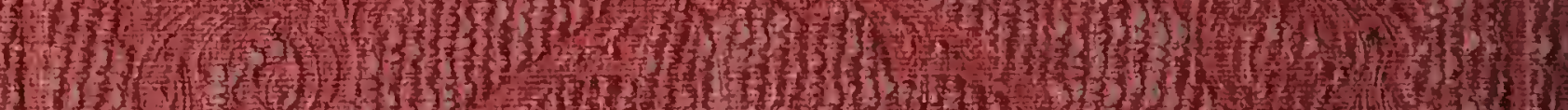

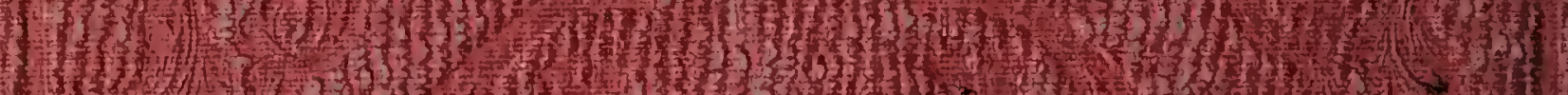

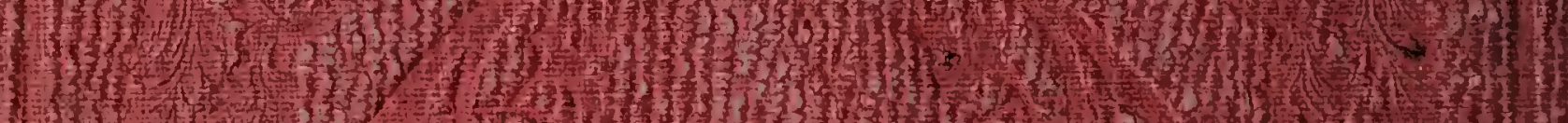

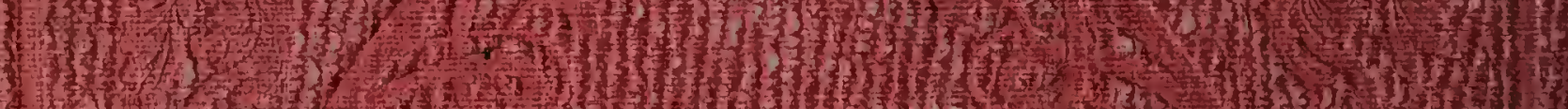

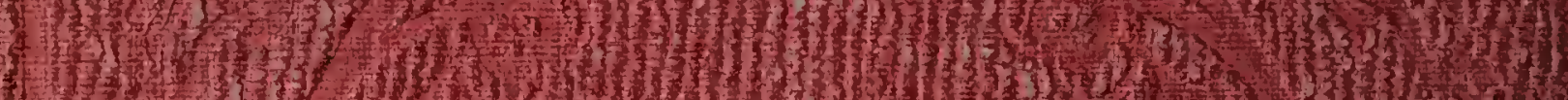

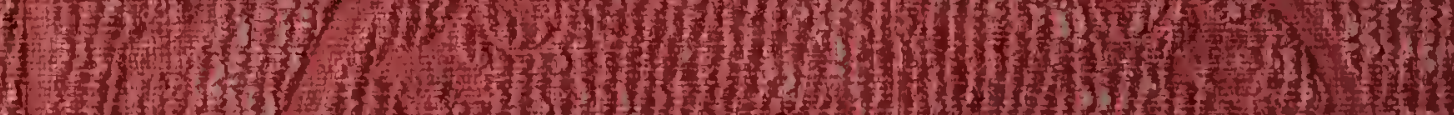

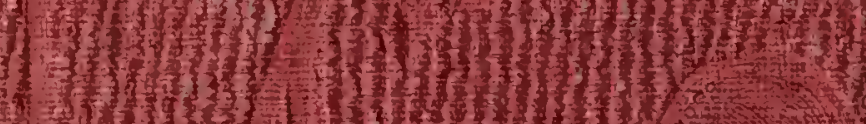

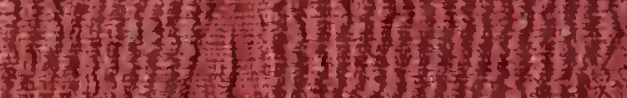
(3)
Wha

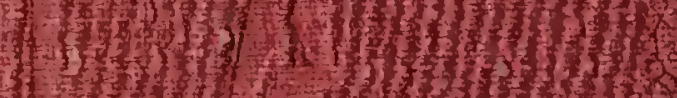

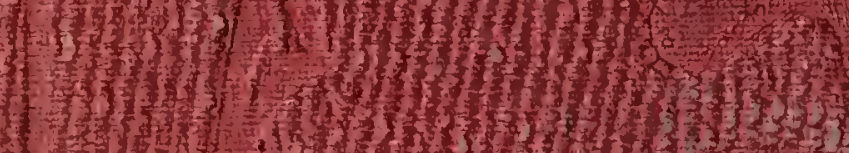

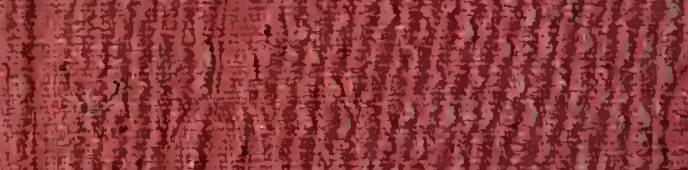

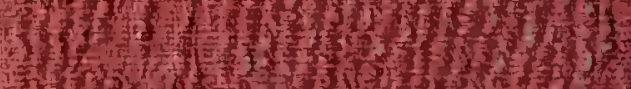

I)

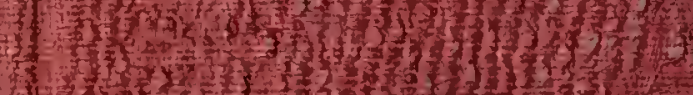

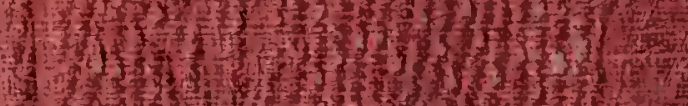

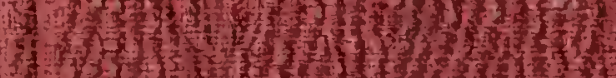

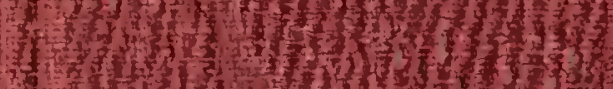

3.5.

1
$H$

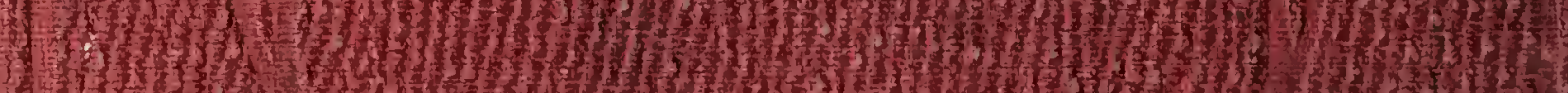

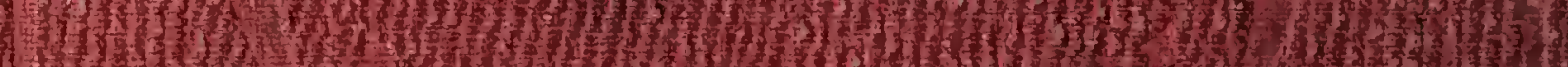

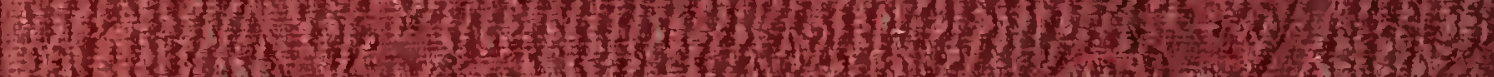

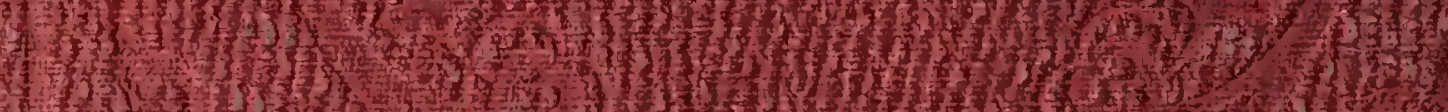

3
3

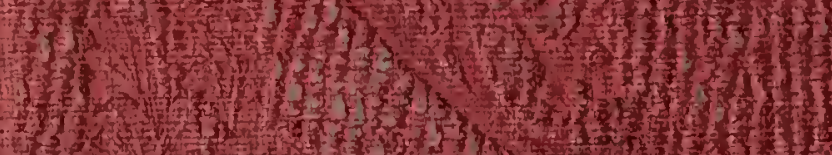

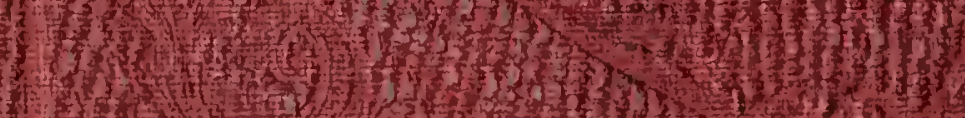

H.

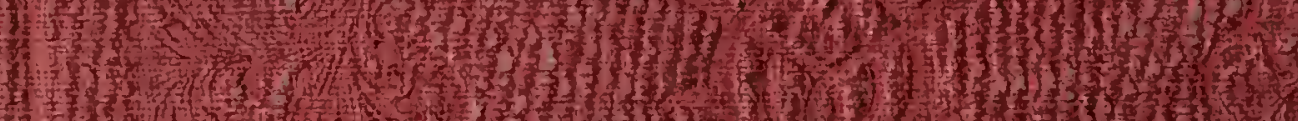

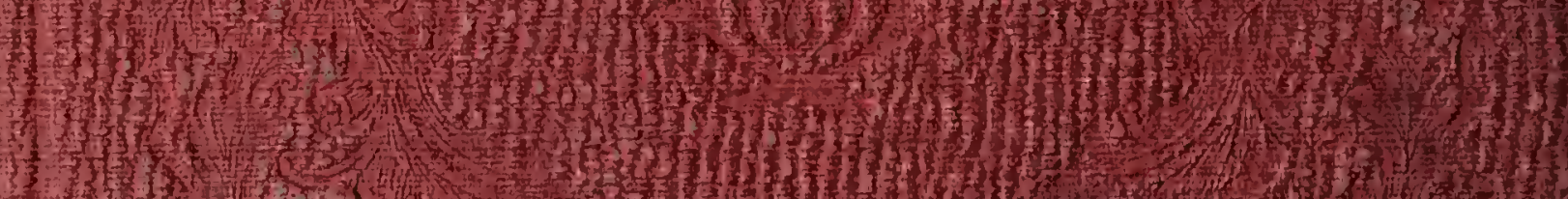

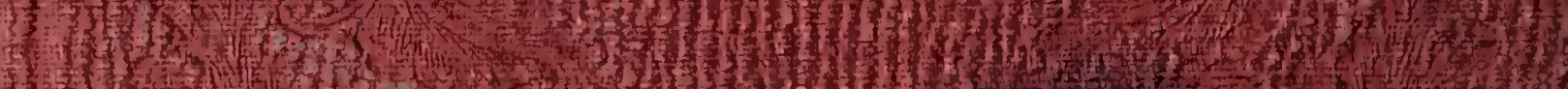

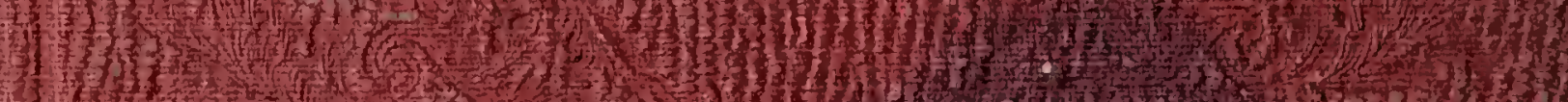

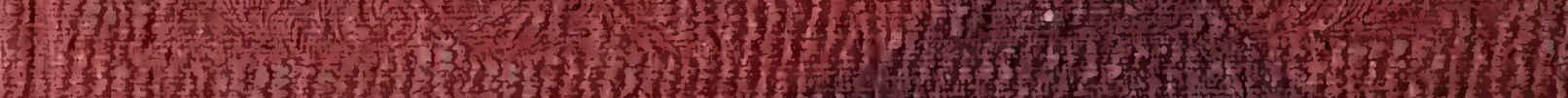

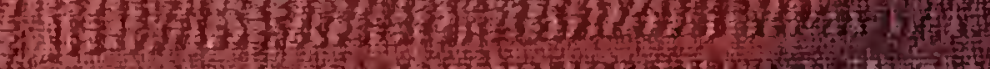

